\title{
Energy Efficient Improvements of Existing Buildings through Building Envelope Upgrade Case Study of High Rise Block of Flats on 76, Boulevard Partizanski Odredi in Karpos IV, Skopje
}

\author{
Katerina Petrushevska ${ }^{*}$ \\ School of Architecture and Design, University American College Skopje, Skopje, Republic of Macedonia
} Citation: Petrushevska K. [Energy Efficient Improvements of Study of High Rise Block of Flats on 76 , Boulevard Partizansk Odredi in Karpos IV, Skopje]. SEE J Archit Des. 2016 May 05 10020:180. [MSc] [Macedonian] http://dx.doi.org/10.3889/seejad.2015.10020

Key words: energy efficiency improvements; building envelope upgrade; existing building stock; sustainable design and construction

Correspondence: MSc Katerina Petrushevska. School of Architecture and Design, University American College Skopje, Skopje, Republic of Macedonia. E-mail katerinakrsteva@yahoo.com

Received: 14-Mar-2016; Revised: 20-Mar-2016; Accepted: 11-Apr-2016; Published: 05-May-2016

Copyright: (๑) 2016 Katerina Petrushevska. This is an openan openCommons Attribution License, which permits unrestricted use, distribution, and reproduction in any medium, provided the original author and source are credited.

Competing Interests: The author have declared that no competing interests exis.

\begin{abstract}
AIM: This research examines the important issue of energy efficient improvements to the existing building stock through building envelope upgrade. To facilitate this, the energy performance characteristics of the existing building stock were identified with a view to establishing an existing building stock type, where building envelope upgrades can contribute to a higher level of energy efficiency improvements. The literature review along with the selected building precedents was used to establish the best current practice for building envelope upgrades.
\end{abstract}

MATERIAL AND METHODS: Established building precedents and identified best practice for building envelope upgrade, a high rise block of flats was identified and used as a case study, with the current and predicted, following building envelope upgrade, energy performance of the building calculated. This has allowed us to identify the possible energy efficiency improvements for this type of building following the building envelope upgrade.

RESULTS: In the projected case, the building with energy class - "D" become class "B". In addition, increased quality of the living room in the attic was enabled. It was possible to obtain a decrease of the heating energy from $130.76 \mathrm{kWh} / \mathrm{m}^{2} \mathrm{a}$ to $37.73 \mathrm{kWh} / \mathrm{m}^{2} \mathrm{a}$ or to jump in the class "B" of energetic passport.

CONCLUSION: This research contributes to the local implementation of the global agenda for sustainable development, design and construction, and it demonstrates the possible way and level of energy efficiency improvements to the least efficient building stock through existing building envelope upgrade. 


\section{Модернизација на постоечките станбени згради}

според принципите на енергетска ефикасност низ пристап за енергетска санација на кулата на бул. "Партизански Одреди бр.76" во населбата Карпош 4

\section{1.Вовед}

\section{1 Одржлива градба}

Актуелната состојба на планетата Земја од социо - економски, еколошки и енергетски аспекти не еволуира кон одговорен и сигурен развој за идните генерации. Несигурноста во снабдувањето од енергетски необновливите извори од една страна и загадување на животната средина проследено со катастрофални климатски промени се појави од кои ќе зависи начинот и нивото на развој и постоење. Обединетите Нации (UN 1992) ја формираат Агендата 21 која има за цел да делува глобално, национално и локално преку системите на $\mathrm{OH}$, Владите и организациите во сите сфери каде дејствува човечкиот фрактор врз природата. Всушност тоа е визија за одржлив развој. "...Одржливиот развој ги спознава потребите на сегашноста без да наштети врз можноста на идните генерации да ги спознаат својте потреби." - Хан (Han 2012:26). Истиот треба да овозможи баланс меѓу екосредината, социјалната еднаквост и економските потреби. Популарните поими како одржлив развој, одржлив дизајн - (проектирање), зелена градба, се актуелни на светско ниво особено со поскапувањата и намалувањето на изворите на фосилните горива. Ова почнува да претставува една верижна поврзаност со начинот на управување со човечките ресурси и дејности. Од тука поимот одржлив развој се раслојува во дејноста градежништво како одржлива градба која е во тесна врска со примената од енергетска ефикасност. Взаемно истите ќе делуваат штедејќи енергија, но со висока комфорност однесувајќи се одговорно кон идните генерации. Со употребата на еколошки материјали, внимавајќи на транспортот и намалувањето на штетните отпадоци при нивно производство и вградување, се минимизира уништувањето на околината и планетата во целина. 


\section{2 Енергетска ефикасност во градежништвото}

Постоечките станбени згради моментално и во иднина не ги задоволуваат современите стандарди и релевантни норми. Тие се предмет на анализа на глобално ниво, како едни од главните виновници на потрошувачка на енергија каде испитувањата изнесуваат $40 \%$ од севкупната енергија. Со развојот на технологијата и потребата од енергија прекумерено се емитува $\mathrm{CO} 2$, каде доаѓа до глобално загревање и загадување на планетата, кое мора да се стави под контрола. Содагар (Sodagar 2013:1) истакнува дека "Потрошувачката на енергија во зградите варира од 25\%-50\% во зависност од држава до држава, каде што се продуцираат 41,7 милиони тони карбон кои се евидентирани во 20042. и претставуваат 27\% од емисиите на карбон во Велика Британија." Поради тоа, објектите претставуваат огромен потенцијал за санација и реконструкција. Според Ломбард и др. (Lombard et al. 2007) социо-економскиот систем, а и одржливоста на истиот е во тесна врска со прекумерената употреба на енергија. Истиот ќе истакне дека заштита од енергетска потрошувачка и емисии на СО2 кај зградите се оозможува со зафатот на Директивата за енергетски перформанси на згради ("Energy Performans of Buildings Directive"EPBD) на глобално ниво. Терминот - модернизација на постоечките станбени згради со енергетско ефикасни мерки, во ЕУ има јасно дефиниран приод кон процес на енергетско санирање (реконструкција), на постоечки градежни структури кој се потпира на ЕУ Директивата (2010/31/EU). Основната цел на истата се однесува на енергетските карактеристики на згради. Во себе содржи барања за формирање на општа методологија за пресметка на енергетскиот биланс на објектите, како и нивно сертифицирање според енергетските карактеристики со независни системи на контрола и инспекцски извештаи за состојбата. Владата на Р. Македонија воведува Стратегија до 2020г. за енергетска ефикасност. Истата е изготвена со техничка и фринансиска помош на УСАИД (USAID) каде меѓу битните програми се и програмите за новите и постоечките објекти објаснува Димитрова (н.п.). Во иницијативата за заштеда на енергијата се вклучува, Македонски центар за европско образование (2010) каде што појаснува за националниот акционен план за енергетска ефикасност, 
каде нашата земја треба да отствари национална заштеда од 9\% од фриналната потрошувачка на енергија. Николовски (2011) во своите јавни излагања го потенцира статистичкиот годишник на Р.М. за 2002 каде е пресметано дека за земјоделие потрошувачката изнесува 4\%, за транспорт $24 \%$, индустрија 33\%, а објектите 39\%. Зградите се големи потрошувачи на енергија, каде е увидено дека во Р.Македонија, станбените згради имаат потрошувачка од $31 \%$, а останатите од $8 \%$. Во истите $17 \%$ оди на топла вода, $12 \%$ на електрични уреди, а $71 \%$ на греење.
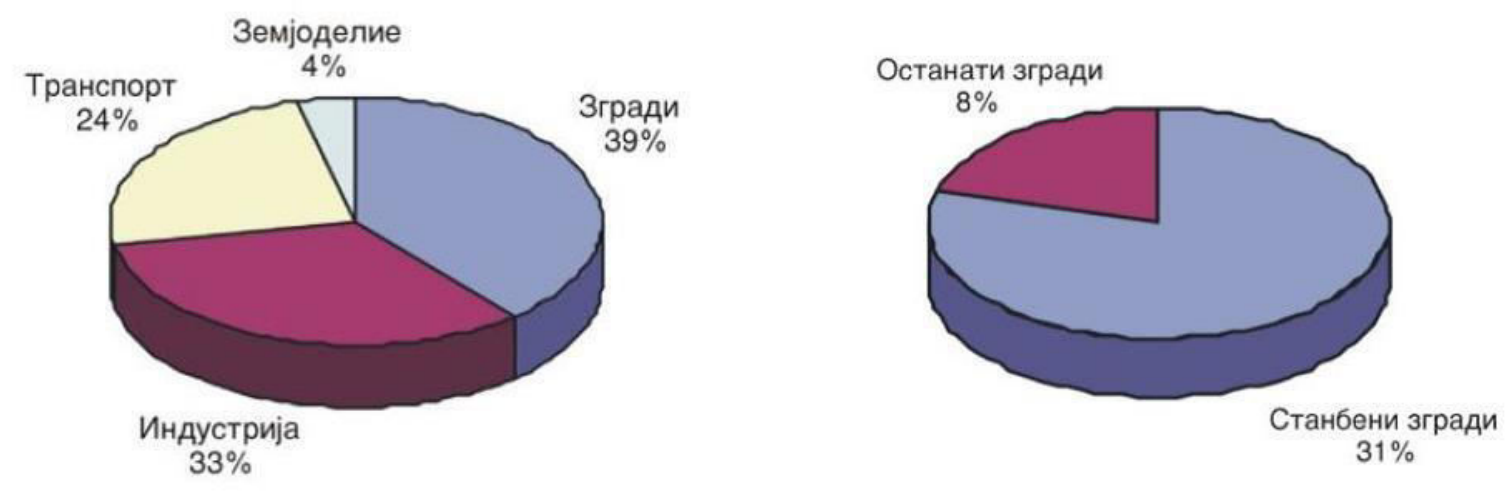

Фигура 1: а) Потрошувачка на енергија во Р.Македонија Извор: Николовски (2011:4)

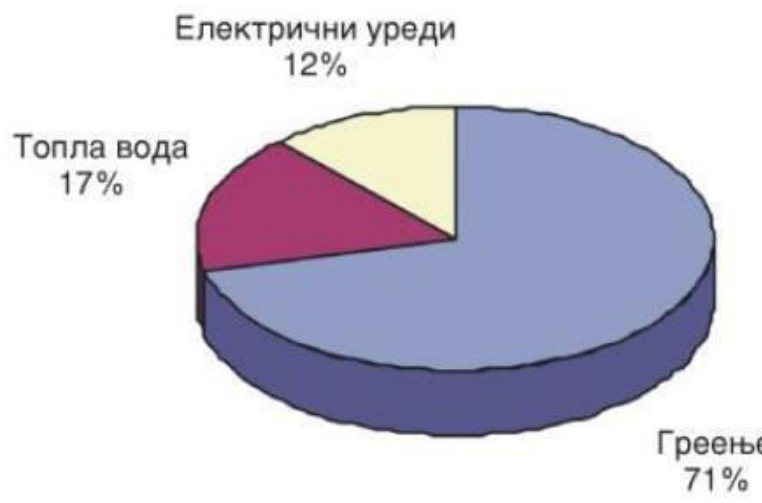

Фигура 1: б) Потрошувачка на енергија во Р.Македонија Извор: Николовски (2011:4)

Овој фракт покажува дека преку санацијата и модернизацијата на постоечките згради може да се заштеди дел од енергијата, а со тоа и да се намалат емисии на CO2. Всушност, енергетската ефикасност во градежништвото претставува област која со имплементација на научно истражени мерки во изведбата на новите и санацијата и модернизација на постоечките згради има за цел да ја намали или минимизира потрошувачката на енергија во зградите. Под овие 
штедливи мерки подразбираме: техничко-технолошки мерки, континуирана едукација и техники, употреба на еколошки материјали и системи со кои ќe ce овозможи подобрување на обвивката на објектот и останатите содржини и инсталации во зградата. Овие мерки се дел од градежната физика кои треба да се сложат во точно определена законска регулатива. Истата би послужила при градба или санација на постоечките згради. Така би се штедела енергија и финансиски средства без последици по комфорот и здравјето. Енергетска ефикасност представува тимска мултидисциплинирана интегрирана работа каде учевствуваат тимови од лица од разни технички профили: архитект, машински инжењери, електро инжењери и градежни инжењери. Вредно е да се напомене значајната улога на архитектот - авторот на архитектонскиот израз на фрасадата на еден објект и начинот на идното планирање на енергетско ефикасен дизајн.

\section{ТЕОРИСКО МЕТОДОЛОШКИ ПРСТАП КОН ИСТРАЖУВАЊЕТО}

Пристапот на истражување во Магистерскиот труд содржи комбиниран метод на истражување сочинет од три останати методи:

1. Студија на случај

2. Квалитативен метод на истражување

3. Компаративен метод на истражување

Предмет на истражување е студијата на конкретен случај која во трудот е претставена преку примерот на модернизација, со примена на одредени мерки за енергетска ефикасност на станбената зрада К4 на бул. "Партизански Одреди бр.76". Останатите два метода служат како помош и надополнување исклучиво на првиот метод. Тоа подразбира дека квалитативниот метод на истражување служи за собирање на податоци преку еден холистички пристап на разгледување на проблемот. Разгледувани се разнородни прашања кои би можеле да бидат од корист на дефинирање за појдовните точки за причините поради што ќе се истражува во трудот, како и последиците, резултатите и целите од овој метод на истражување. Всушност квалитативниот метод претставува абсорбирање на материјалот кој е во служба на конкретно изработување на методот - студија на случај. Истиот овозможува податоци 
преку снимање на постоечката состојба која ќе претставува основа за разработка на студија на случај методата. Приложува општо видување на проблемот со вклучен историско интерпретативен метод. Разработува прашања кои бараат констатација на состојбата и решавање на проблемот пред планираната модернизација на постоечките згради. Ги детерминира критичните точки на предметот на истражување. Квалитативниот метод разработува податоци од испитување на терен, состојбата на конкретниот пример, состаноци од куќен совет кои овозможуваат согледување на потребите и проблемите. Разгледано е едно општо видување на целокупната потрошувачка на енергија и квалитетот на живот во постоечките станбени објекти во Република Македонија и на светско ниво. Овој метод собира податоци и од законските механизми за имплеметирање на мерките за енергетска ефикасност како и вклучува посета на семинари кои ќе претставуваат дополнителна помош кон пристапување и видување на можните проблеми и решенија. Со еден збор опфатени се општите состојби и прашања кои треба да се апсолвираат пред превземање на било каква модернизација, се̉ со цел подобро дијагностицирање на состојбата и можните проблеми. Компаративниот метод на истражување презентира зафати на обнова на станбени згради од западна и источна Европа како и од Република Македонија кои ќе служат како надополнување во истражувачкиот труд. Истите ќе овозможат едно видување на нештата кои се одвиваат во Европската Унија и во нашата земја, како и искористувањето на знаењето и практичната примена на тамошните модернизации на постоечки згради. Целта на овој компаративен метод на истражување во трудот е да направи една споредбена анализа на резултатите кои се добиени од студија на случај и дадените европски примери. Со тоа би се добило увид за фрактичката состојба на РМ кон имплементирање на мерките за енергетска ефикасност, приближување до законските регулативи и нивно спроведување, едукација на стручните кадри, информираност до сопствениците на станови и континуитет кон одржливиот развој во оваа област. На завршниот дел од студијата на случај, по добиените резултати од применетите методологии и математички пресметки заедно со графичкиот дел од трудот - (проект за реконструкција на обвивката на зградата), може да се формира споредбена анализа на состојбата на планирана модернизација во РМ и дадените примери. Со ова би имале увид кон дополнително 
спроведување на европски регулативи и веднаш формирање на енергетски пасоши на згради. Од тука методот студија на случај резултира со веќе вградени податоци за постоечка состојба во вид на проект на постоечка состојба претставен, графички во прилог бр.5. Истиот служи за анализирање и пресметување на состојбата на потрошувачка на енергија за греење, која ќе биде пресметана според Правилникот на Општина Карпош (2012). Покрај тоа разгледана е постоечката состојба на фрасадата, констатирани се топлинските мостови, критични места и загуби. Детектирани и фотографирани се местата каде топлинските мостови дејствуваат и оштетуваат со влага и мувла. Со примена и интегрирање на материјали за изолација кои треба да ги задоволат коефициентите за премин на топлина, се изработува елаборат за градежна фризика, повторно според методологијата за пресметки на Правилникот на ОК (2012). Потрошувачката на топлинска енергија е изразена во $\mathrm{KWh} / \mathrm{m}^{2} \mathrm{a}$ (киловат-часови на еден метар квадратен потрошувачка на енергија за греење на годишно ниво). Покрај овој вид на истражување, во останатиот дел од студијата на случај изработен е проект за модернизација на нова состојба на станбената зграда, со интегрираните енергетско ефикасни мерки - Прилог бр.5. Од тука може да се наведе дека квалитативната и компаративната метода создава теоретско истражување, додека студијата на случај во делот од аудитот, претставува емпириско истражување. Теоретската позадина на која е создадено истражувањето е преку преглед на литература која опфаќа едно пошироко видување на проблемот на прашањето на модернизацијата, која покрај предложената санација и реконструкција на кров и фрасада на постоечкиот објект, треба да резултира со повратен бенефит. Претставени се општите состојби на светско ниво, стратегии и очекувања низ еден пристап на одржлив развој, со цел за задржување на квалитетот како и за човечките така и за енвиронменталните потреби за идните генерации. Механизмите кои ќе ги спроведуваат овие постапки се европските директиви, регулативи, енергетските контроли и правилници, елаборати за енергетска ефикасност и конечен производ - енергетски сертификат. Историско интерпретативниот метод овозможува континуирано согледување на развојот на проблемот, а не е исклучена и анализата на постоечките проблеми како и нивното совладување. Од тука најмногу користена литература ќе биде книги од соодветна област, превземени од нашата земја и странска литература, како и интернет 
публикации, конференции, владини публикации, трудови, брошури, журнали. Во трудот се користат дополнително и фотографии кои се превземени од интернет, книги, добиени од семинари, и самостојно обезбедена фрото документација која ќе служи да го дообјасни и формира сликовито даденото истражување. Табеларниот приказ би помогнал во компаративниот метод каде делумно е превземен од дадените примери, а останатите дадени примери како и студијата на случај фрормира табеларен приказ по принципот на европските примери. Проектот во студијата на случај, содржи графички прилози добиени според архитектонски принципи, самостојни фото прилози, како и математичко градежни пресметки потпомогнати и добиени од проектот- графичките прилози. Методолошкиот пристап при модернизацијата на постоечката станбена зграда е дефиниран преку стратешки пристап на преобликување на обвивката на зградата. Резултатите од истражувањето ја дефинираат енергетската заштеда и подобрувањето на конфортот во градежната структура, за одредени мерки на интервенција во истиот. Целите се разнородни со тоа што, покрај придобивките од енергетска ефикасност, внимание е обрнато да не се нарушат и обликовните, конструктивните и функционалните вредности на станбениот објект. Особено е посветено внимание на архитектонскиот израз кој треба да биде во корелација со современите трендови. Всушност, целта е да се добие нова обновена обвивка на зграда, која ќе овозможи заштеда на трансмисионите топлински загуби. Согласно поставените цели во предметот на истражување се очекуваат повеќе резултати, кои треба да бидат исполнети по извршеното истражување или модернизација на постоечката зграда. Со формиран увид на состојбата на зградата од конструктивен и енергетски аспект, потоа со пресметаната енергетска топлинска потрошувачка на постоечката состојба би добиле резултат за реалната топлинска потрошувачка на зградата. Сопствениците на станови би добиле слика за моменталната состојба на зградата. Истите би се запознале со можностите за заштеда по обновата на објектот. Будењето на чувството на квалитетно живеење, подобрување на комфортот во објектот и можност за вистинско практично имплементирање на мерките за енергетска ефикасност или реална можност за обнова на зградата во соработка со граѓаните и општината. Истражувањето ќе овозможи едно видување на состојбата и преглед на работите, кои ќе можат да ги искористат соодветни сертифицирани кадри. 


\section{2.Хронологија на законската регулатива}

\section{(Европските директиви и регулативата на балканскиот регион)}

\section{1 Европски Директиви}

Европските директиви ги дефинираат главните механизми и принципи за постигнување на енергетската ефрикасност во градежниот сектор. Тие претставуваат основна платформа за регулативите и прописите во градежништвото каде мора да се почитувани од сите земји членки на ЕУ. Земјите кандидати за членство на ЕУ треба полека да се прилагодуваат со преведување и прилагодување на европските стандарди. Основна европска директива за градежните објекти која има за цел практичен пристап и промовирање на подобрувањата од енергетски санации и заштеди при реконструкција на постоечките згради и новоградбите е директивата 2002/91/ ЕЦ (Council Directive 2002/91/EC on the energy performance of buildings EPBD). Подоцна Европската Комисија (European Parliament and council 2010) ja преработува и ја именува како Директива за Енергетски Карактеристики на Згради (Energy Performans of Buildings Directive 2010/31/EU (recast).

Според Европскиот Комитет за Енергетско Ефикасна Економија (European Council for an Energy Efficient Economy - ECEEE 2010) главните и преработени услови од истата, кои ќе треба да се имплементираат се:

- Општа унифицирана методологија за пресметка на енергетските карактеристики на градежните конструкции.

- Минимални барања за енергетски карактеристики на нови згради и постоечки згради, нивни делови или градежни елементи кои се предмет на реконструкција).

- Енергетско сертифицирање на згради или нивни делови, со независни инспекциски системи поготово кај критичните градежни структури.

Една од мерките која привлекува најголемо внимание во ЕУ е амбициозноста на препораката, за новите згради да бидат градени како "нула енергетски згради" до 2020 година. Интересно е да се нагласи дека ECEEE (2010) со преработената директива предвидува зголемување на енергетските перформанси на постоечките згради на едно повисоко ниво. Со тоа во Европа 
се става главниот акцент во потенцијалот на модернизацијата на постоечките згради кои опфаќаат голем број на урбани структури, дури до 60\%. Според Центарот за истражување и креирање политики (2013) Европската Унија формира стратегија со таканаречена енергетска триада 3 × 20 (20:20:20) со концепција за: заштеда на енергија, заштита на животната средина, намалена зависност од необновливи извори на енергија. Идејата е до 2020г. да се :

$-20 \%$ намали потрошувачката на енергија.

$-20 \%$ намали емисијата на CO2.

$+20 \%$ зголеми употребата на обновливи извори на енергија.

Енергетското тројство е императив за сите земји вклучувајќи ја и нашата.

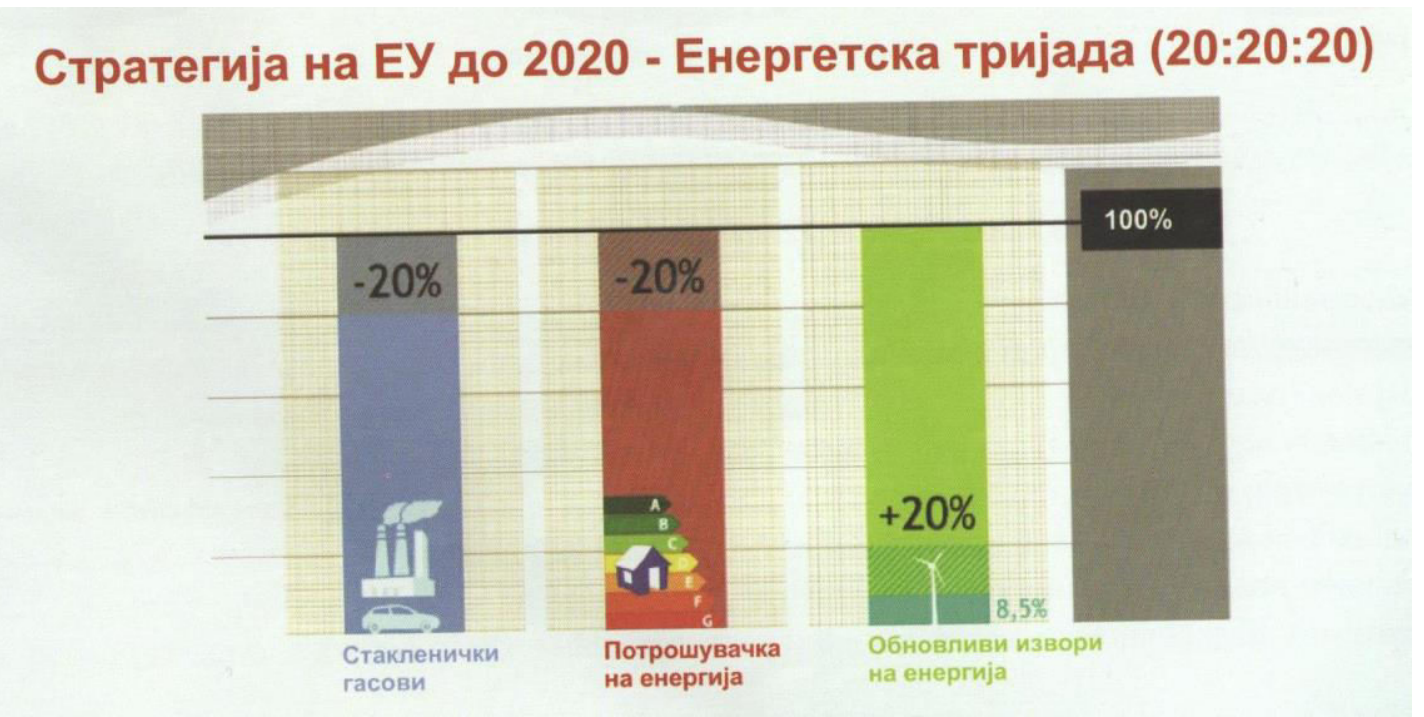

Фигура 2: Стратегија на ЕУ до 2020 - Енергетска тријада (20:20:20)

Извор: ААМ (2012:7)

2.2 Односот меѓу директивата (EPBD) и стандардите (EN)

Основна задача на ЕУ Директивата (2010/31/EU) е да воведе генерална методологија за пресметка на вкупните енергетски карактеристики на згради. Европскиот комитет за стандардизација (CEN) се овластува за разработка на стандарди и методи за подкрепа на постапката за пресметка на истата методологија. Според Штрбац (2011) главна цел на стандардите е олеснување на примената и имплементација на Директивата на земјите на ЕУ. Стандардите се основа за национална регулатива за енергетска ефикасност на зградите. Николовски (2011) потенцираше дека Институтот за стандардизација на 
Република Македонија - ИСРМ има усвоено 170 стандарди донесени од европскиот комитет за стандардизација.

CEN ги припреми стандардите со префикс EN и EN ISO каде :

EN - Европски комитет

ISO - меѓународен комитет за стандарди

ИСРМ на истите стандарди додава префикс МК кој со одбран Технички комитет започнува имплементација и преведување на истите. Од тука стандарди за повисоко ниво на интегрирано проектирање за пресметка на нето енергија за греење и ладење се:

MKC EN 13790, MKC EN 15255, MKC EN 15265,

Стандарди за подршка како топлински карактеристики на градежни компоненти МKC EN ISO 6946 - Umax и т.н.

За пресметување на потрошувачката на енергија за греење во градежната фризика, според Правилникот од Општина Карпош (2012), како и според националниот Правилник се користат следните термини:

Вредност U ( изразена во [ $\left.\mathrm{W} /\left(\mathrm{m}^{2} \circ \mathrm{K}\right)\right]$ )

U - фрактор е коефициент на пренесување на топлина. Претставува количевство на топлина која некој елемент ја губи за една секунда на м³ површина при разлика на температура од 1 К. Коефициентот $U$ е важна карактеристика за надворешните делови на градежните конструкции. Има значајна улога во пресметката на топлинските загуби и потрошувачката на енергија за греење. Градежните фризичари појаснуваат за $U$ коефициентот на пропусливост, колку е помал толку е подобра топлинската заштита на зградата. Од тука се усвоени U вредности за секоја држава, со мах. дозволена топлинска пропусливост за сите делови на градежните конструкции. Вредноста $U$ e реципрочна вредност од сумата на топлински отпори $\mathrm{R}$ т на градежната конструкција. $\quad U=1 / \mathrm{R} T$

$\mathrm{U}=$ коефрициент на пропусливост на топлина $\left[\mathrm{W} /\left(\mathrm{m}^{2} \circ \mathrm{K}\right)\right]$.

W - Ват

m - метар

К - Келвин 
Вредност $\lambda$ ( изразена во [ W / (m॰K) ])

Според Рекнагел и Спренгер (Recknagel -Sprenger 1982)

во градежната фризика, топлинските загуби низ градежните елементи (обвивката на зграда) зависат од коефициентот на топлотна проводливост $\lambda$. Коефициентот $(\lambda)$ - Зависи од хемискиот состав, густината, порозноста, температурата и влажноста на материјалот и претставува лична карта на материјалот. Вредноста $(\lambda)$ претставува количество на топлина која за време на 1 сек. минува низ материјал со дебелина $1 \mathrm{M}$ и површина од $1 \mathrm{M}^{2}$, при температурна разлика од 1 К меѓу две страни на материјалот. Помала вредност значи поголем отпор и помало количество спроведена топлина.

$\lambda=$ коефициент на топлотна спроводливост [ $\mathrm{W} /(\mathrm{m} \circ \mathrm{K})$ ]

W - Ват

m - метар

К - Келвин

\section{Топлински отпор се пресметуа според МКС EN ISO 6946/ A1}

\section{Топлински отпор $\mathbf{R}\left[\left(\mathrm{m}^{2} \circ \mathrm{K}\right) / \mathrm{W}\right]$}

Топлински отпор на слој на материјал $\mathrm{R}$ e количник од дебелината на материјалот $\mathrm{d}$ и вредноста $\lambda$.

\section{Површински отпор Rs}

Николовски во ААМ (2012) појаснува за топлинскиот отпор на кој наидува топлината при премин од внатрешниот воздух кон површината на првиот внатрешен слој на некоја конструкција Rsi и од надворешната површина на последниот слој на конструкцијата кон надворешниот воздух Rse.

Сумата на топлински отпори $\mathbf{R} \mathbf{T}=\mathrm{Rsi}+\sum \mathrm{R}+\mathrm{Rs}$

\section{3 Енергетски пасоши - сертификати}

Енергетските сертификати се воведуваат во земјите на ЕУ со цел да се овозможи еден механизам за отстварување на енергетската ефикасност во објектите. Во Директивата (2010/31/EU) разработени се и анализирани топлотните загуби кај типови на згради кои се градени во различни години, со различни материјали и термо изолациони додатоци. Констатирано е дека огромен дел на термичката енергија (трансмисиони загуби) се губи низ обвивката на зграда, поточно кај лошо изведените обвивки или кај воопшто 
неизолираните објекти. Поради оваа состојба се воведува сертификација кај новите но и кај постоечките згради, која меѓу другото ќе претставува и голем маркетиншки инструмент кој има за цел да ја промовира одржливата градба, подобар квалитет на живот, развој на позитивниот однос кај сопствениците на станови кон околината и самата урбана структура како и отварање на нови работни места. Главната цел е транспарентност на податоците за потрошена енергија во објектите како и количеството на емисии на CO2. Борковиќ (Borkovič 2012) ги споменува воведувањето на казнените мерки за не прилагодување кон ЕУ Директивата (210/31/EU). Разгледувани се можни такси за објектите кои редуцираат СО2 над дозволените граници со што би се поттикнало зголемување на енергетската санација и модернизација на постоечките згради. Со тоа и би се зголемил рејтингот на означување кај енергетските сертификати кои се движат со енергетска потрошувачка од " A+" - "G," ( фигура 3).

Секако од ова произлегува логичната проценка на вредноста на објектите при продажба или наем. Според организацијата за интелегентно користење на енергија (Intelligent Energy Europe - IEE н.п.) за постоечките згради овие сертификати во ЕУ се дел од купопродажните договори, каде сопствениците се должни при продажба, наем или подигање на кредит да ги обезбедат. Енергетските сертификати на новите згради се обезбедуваат при проектната документација, додека за постоечките објекти мора да се обезбеди детален "енергетски преглед". Енергетскиот сертификат во Европа има важност од 10 години, потенцира ИЕE (IEE н.п.). Истиот содржи податоци за годишно потребна потрошувачка на енергија (енергија за греење, ладење, вентилација, топла вода, осветлување, количество на емисија на $\mathrm{CO} 2$, препораки за санирање). Со оглед на опипливоста на поделбата на енергетскиот учинок во различни типови на објекти, енергетските сертификати овозможуваат јасна слика за енергетската ефикасност. Од тука ќе почне поделбата на цената на недвижности како и начинот на размислувањето на архитектите, градежниците и градителите. 


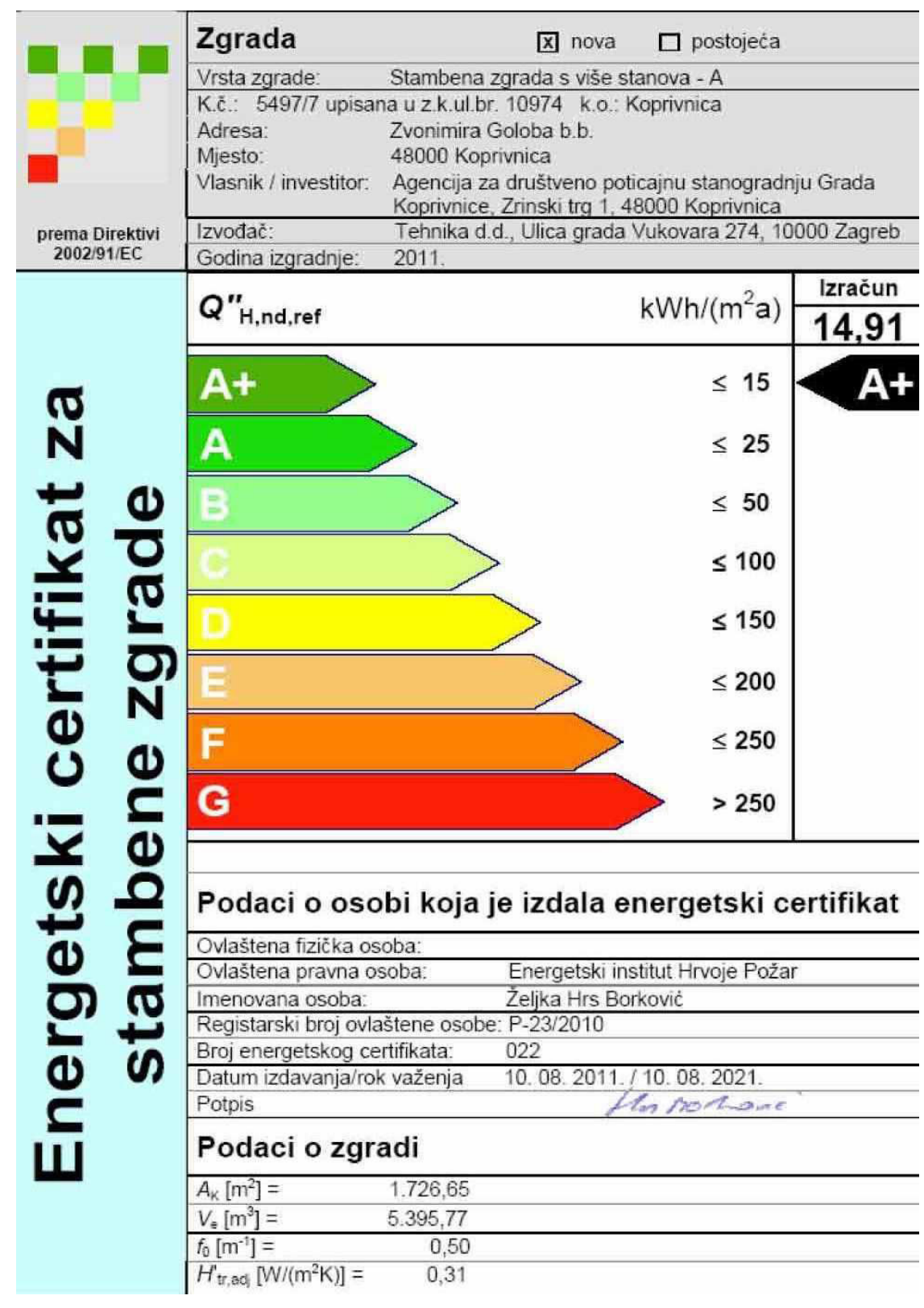

Фигура 3: Енергетска сертификација на зградите во Република Хрватска Извор : Борковиќ (Borkovič 2012:12)

2.4 Означување на градбите според енергетските перформанси

Различните ознаки за енергетски учинок кај енергетските сертификати ги покажуваат различните типови на енергетско ефикасни градби. На тој начин е овозможена споредба на енергетските карактеристики на згради. ИЕE (IEE н.п.) објектите ги разложува на : 
- Стандарден објект

- Нискоенергетски објект (енергетско ефикасен)

- Пасивни објекти

- Енергетски неутрална зграда

- Зелени објекти

Стандардно изолиран објект - троши годишна енергија за греење од 80-100 $\mathrm{kWh} / \mathrm{M}^{2}$. Во ознаките кај енергетски пасоши уште се споменуваат како објекти од "C" категорија. Овие објекти се конструирани со минимални мерки за потребите на енергетска ефикасност истакнуваат ИЕE (IEE н.п.).

Нискоенергетски објект (енергетско ефикасен) - Според Европската Комисија (European Commission н.п.) овие објекти влегуваат во националните планови во Европската Директива. Во истите $80 \%$ од енергијата треба да се заштеди преку интегрирани решенија во дизајнот на истите. Тоа подразбира високо ниво на термо изолација, енергетско ефикасни прозорци, ниско ниво на инфилтрација на воздух и механичка вентилација, со што се постигнуваат ниско енергетски трошоци. Европската Комисија (European Commission н.п.) ги дефинира овие објекти со назив ниско енергетски, кои трошат од 40-60 kWh/m на годишно ниво што овозможува "В" рејтинг во енергетскиот пасош. Во акција да ги дефинира термините низ Европа, ЕК (European Commission н.п.) идентифицира повеќе различни термини. Одредени згради се сведени на потрошувачка на енергија за греење од $30 \mathrm{kWh} / \mathrm{m}^{2}$. Според организацијата за заштеда на енергија (Energy Saving Trust - EST 2010) со примена на софттерско решение може да се доведе објектот до "В" класа во енергетските пасоши. Просечната станбена категорија за Велика Британија e "D" категорија на скалата на енергетски пасоши од "A" - "G". Доколку се добие "B" рејтинг по реконструкција на објектот тоа значи дека за $80 \%$ се намалени емисиите на $\mathrm{CO} 2$.

Пасивни објекти - Според Кауфрман (Kaufmann 2010) пасивните куќи трошат до $15 \mathrm{kWh} / \mathrm{M}^{2}$ на годишно ниво енергија за греење, со ознака "A+" во енергетските сертификати. Потекнуваат од институтот за пасивни куќи во Дармштад (Darmstadt - Passive House Institute), како независна истражувачка институција. Тие претставуваат високо софистициран систем на изведба каде во зимите и летата пружаат најголема удобност без употреба на активен 
систем на греење. Топлината и разладувањето се постигнува преку високософистициран систем на рекуперација и можностите на догревање. "Обвивката на фасада" е доста поголема од останатите типови на објекти, со што се занемаруваат топлинските мостови како и провевот во просториите. Прозорите се со трослојно стакло со високи перформанси со исполна од благороден гас. Според Кауфмман (Kaufmann н.п.) треба да се запазат пет главни принципи за објектот да троши енергија од $\leq 15 \mathrm{kWh} / \mathrm{M}^{2} a$, карактеристична за пасивните куќи и тоа:

1. Воздушно непропусна обвивка на фасада, $\mathrm{n} 50 \leq 0,6 / \mathrm{h}$

2. Термоизолациона обвивка на фрасада со коефициент $U=0,15 \mathrm{~W} / \mathrm{M}^{2} \mathrm{~K}$

3. Механичка вентилација, систем со топлински повраток $\eta \geq 75 \%$

4. Трослојно застаклување со коефициент $U=0,8 \mathrm{~W} / \mathrm{M}^{2} \mathrm{~K}$

5. Избегнување на ефекти од термички мостови $\Psi а \leq 0,01 \mathrm{~W} / \mathrm{MK}$

Енергетски неутрална зграда - овие згради се најголемата амбициозна цел на ЕУ Директивата 2010/31/EU до 2020г. Според Националната лабараторија за обновливи енергетски извори (National Renewable Energy Labatory- NREL 2006), концепрот на функционирање на овие згради е идејата дека целата побарувачка на енергија за потребите на објектот може да се овозможи од обновливи технологии и извори на енергија. Секако тоа ќе се постигнува преку софистицирани фотоволтаични системи и обновливи извори на енергија. Покрај тоа истите обновливи избори треба да се локално достапни и еколошки. Објектите може да бидат станбени и јавни.

Зелени објекти -. Зелени згради се конструкции кој покрај енергетската ефикасност, влијаат на надворешната околина на безбеден начин, во смисла на заштита на употреба на земјиштето како простор, водата и енергетските ресурси, дефинира владин совет ( Governars Green Government Council - GGGC н.п.). Според Хове (Hove н.п) зелените згради внимаваат на употребата на земјата, зеленилото кое го пренесуваат на себе, рециклирањето на водата, изградбата од рециклирани материјали, квалитетот на воздух. Истиот кажува дека дефиницијата за овие објекти континуирано еволуира во смисла на подобрување на влијанието кон околината и човековото здравје. Овие згради се самоодржливи или уште се нарекуваат интелигентни згради, истите се во хармонија со одржливиот развој. 
2.5 Правни одредби и воведување енергетски пасоши кај земјите од балканскиот регион

Републиките од бившите Југословенски простори како Република Хрватска, Србија и Босна и Херцеговина се стручно навлезени во оваа област. Нова законска обврска на Р. Хрватска и Р. Србија е да воведат енергетски сертификат за недвижностите. Во моментот енергетскиот сертификат се означува според специфична годишна топлинска енергија за греење. Понатаму истиот е со идеа да се развива со воведување на вкупната потрошувачка на енергија кај зградите. Борковиќ (Borkovič 2012:10) потенцира дека - "Сuте постоечки градби кои се на продажба, се даваат под наем или на лизинг мора да имаат енергетски сертификат достапен на увид на купецот или наемопримачот најкасно до денот на пристап на Р.Хрватска во членството на ЕУ." Граџевинар (Gradjevinar 2012) приложува дека хрватската стопанска комора (Hrvatska Obrtnicka Komora -HOK) организира конференција на тема енергетската ефикасност во зградите. Разгледани се прашања и донесени се заклучоци од оваа област со што е најавено дека ќе настанат промени во законодавните решенија во градежниот сектор и енергетската потрошувачка. Понатаму е заклучено дека во наредните десетина години градежниот сектор ќе се ориентира кон санација и модернизација на постоечките згради по енергетско ефикасни принципи, а новоградбите ќе бидат изведувани со ниско енергетски перформанси. Секако тука се потенцирани и нови законодавни рамки. Министерството за животна средина, (2011) на Р. Србија донесува Правилник за енергетска ефикасност на зградите. Во истиот Правилник (2011:1) според член 1. - " (...) се пропишуваат енергетски својства и начини на пресметка на топлотните својства на објектите од високоградба, како и енергетски услови за нови и постоечки објекти." Букарица (Bukarica 2012) користејќи ги европските и примерите од двете соседни држави појаснува за енергетската ефикасност во многу дејности, а секако не е исклучок и градежниот сектор со потенцирани десет точки од Директивата 2010/31EУ. Во Законот за градење на Р.Македонија, членот 9 (Сл. Весник на РМ, бр.59 од 20/04/2011) го појаснува ефикасното користење на енергија и топлинска заштита. Во Членот 134 (Сл. Весник на РМ, бр.16 од 10/02/2011) од Законот за енергетика целта е постигнување енергетска ефикасност кај објекти со 
претходно исполнување на неколку наведени услови. Во Членот 5 (Сл. Весник на РМ, бр.39/06,бр.86/08,бр.47/11,бр.139/11) од Законот за градежни производи се потенцира штедење на енергија и задржување на топлина. Овој термин најавува елемент на подобрување или комфорт. Во 2008 година во Р. Македонија е донесен Правилник за Енергетска ефикасност на градежни објекти, кој не е оперативен. Истиот прво е објавен во Сл.весник на Р.М. во 2008, со примена од 01/Јануари 2010. Понатаму во Сл. Весник на Р.М.од 2009 е повторно одложена примената за 31 декември 2011. Денес не е во функција. Од 2008 - 2012г Општина Карпош - Скопје се залага за имплементирање на енергетско ефикасни мерки во јавните, а подоцна и во објектите за домување. Формирано е оделение за енергетска ефикасност кое во своите публикации (2012) приложува документ во кои се наведени заложувањата за обнова на станбените згради за домување. Општината Карпош - Скопје ја изведува реконструкција на обвивката на фасада на 6 згради, додека станарите кои се кредитирани од Хабитат ги заменуваат прозорците на фасадите. Интересен е податокот дека постоечките објекти пред реконструкција трошеле 200-300 $\mathrm{kWh} / \mathrm{m}^{2} a$ енергија за греење, додека по реконструкција потрошувачката на топлинска енергија изнесува 100 kWh /m²a. Општина Карпош (2012) прва во Р. Македонија донесе Правилник за мерките за енергетска ефикасност кои треба да ги исполнат проектите за изградба на нови и реконструкција на постоечки објекти како услов за добивање на одобрение за градење. Со истиот предлог Правилник е пресметана методологијата на елаборатот за градежна фризика на студијата на случај од овој магистерски труд.

Во меѓувреме во Сл. Весник на РМ, бр.94 од 4.7.2013 објавени се два правилника. Првиот е: Правилник за енергетски карактеристики на зградите, а вториот е Правилник за енергетска контрола. Николовски, како еден од авторите на овој правилник и автор на предлог Правилникот во О. Карпош ќе истакне дека ..."корените на новиот Правилник датираат уuте од 20072." Пресинг (2013:51). Авторот сака да укаже и за несовршеноста на Правилникот како и можностите за негово доусовршување. 


\section{3.Типови на конструкции според годината на изградба}

3.1 Постоечките згради во Република Македонија

Зградите во Република Македонија, според начинот и видот на изградбата се поделени на неколку периоди. Според Николовски во Австриска Развојна Корпорација - АРК и др.(2011) споменета е следната поделба:

- Периодот на градби пред земјотресот 1963г.

- Периодот на градби од 1965 до 1980г.

- Периодот на градби од 1981г. (период од 1981-1991г. во рамките на Југославија).

- Периодот на градби од 1991 до 2013.

Секако, во Република Македонија има податоци за градбите и пред периодот на горе наведената поделба.

- Периодот на градби од 1918г.

3.2 Периодот на градби околу 1918г.

Нашата градителска традиција е позната на Балканот и подалеку. Старите македонски куќи се градени од локални материјали : камен, ќерпич, плитар и дрво. Според истражувањата на Грабријан (1986) станбените конструкции се куќ од необработен реден камен, сврзани со кал и глина. Улогата на серклажниот елемент зацврстувач, кој природно се наметнува на конструкцијата се хоризонталните дрвени појаси. Од тешкото приземје се преминува кон лесната дрвена катна бондручна конструкција, разнолика во зависност од град до град. Некаде зидовите од катната конструкција се фино малтерисани, стегнати во "плацки штици". Надворешната бондручна конструкција, е облжена од внатре и надвор со плацки штици или трска, а потоа малтерисани. Во внатрешноста на фасадниот зид има исполна од ќерпич и слама или воздух. Ова претставува висококвалитетен начин за заштита од студ и прегрејување. Покривната конструкција е дрвена со наклон од $18-26^{\circ}$ со олучести керамиди или шкрилести плочи. Кровот е во фрорма на пирамида со 
длабока стреа. Обликовен елемент се еркерите и чардакот. Чардакот е елемент кој служи за заштита од сонце, а воедно Грабријан (1986) споменува дека идеите на Le Corbusier за терасите со "brise soleil" (брисолеи) се токму од Македонскиот чардак. Понатаму нагласува дека таква идеја не би можела да дојде од северна клима. " Тремот и чардакот се сенчестите места пред куќата." - Грабријан (1986:160). Според Вестел (н.п) најголема градежна активност на станбени објекти во Скопје од ова време била забележана во периодот од 1924-1930.

\section{3 Периодот на градби пред земјотресот 1963 г.}

Зградите се карактеризираат со sид од полна тула 25-38-50см, структурата е од носечки зидови и меѓукатна конструкција - систем "Авраменко". Обично спратноста на овие објекти е П+5 ката. Кровот е изведен обично во дрвена кровна конструкција и е покриен со керамида. Прозорците и вратите се двојни, дрвени застаклени со две стакла или крило на крило. Кај овие типови на прозорци високата пропусливост на воздух кај дрвените рамки ја влошува $U$ вредноста или коефициентот на премин на топлина, која кај овие елементи е повисока од $3,5 \mathrm{~W} / \mathrm{m}^{2} \mathrm{k}$. Материјали за топлинска изолација воопшто не се користат, но од термичка гледна точка, дебелината на полната тула овозможува многу подобри резултати од аспект на премин на топлина во летниот период од надвор кон внатре и обратно. Интересно е да се напомене дека - "Со воведување на стандардот за греење на просториите над температура од $18^{\circ} \mathrm{C}$ кај овој вид на sидови се губи голема количина на топлина и се појавува проблемот со влага."- Кнежевиќ (Knezevič 2009:10). Просечните загуби кај овој вид на згради се испитани на 200-250 kWh/m²a. Со санација и модернизација овие згради имаат заштеда од $70 \%$ или потрошувачка на енергија за греење од 60-90 kWh/m²a.

3.4 Периодот на градби од 1965 до 1980 г.

Поради строгите сеизмички прописи кои се наметнуваат во овие години кај подрачја подложни на земјотреси, многу е изведуван скелетниот армиранобетонски систем. Армираната носечка скелетна конструкција не задоволува 
термички, а исполната на зид со шуплив керамичли блок од 19-25 см е со доста слаби топлински карактеристики. Материјали за изолација слабо се користат. Во некој од овие згради може да се сретне употреба на хераклит, дрволит, кои се ставаат во оплатата за време на бетонирање. Николовски во АРК и др.(2011:6) потенцира дека "Според фрактите, споменатите објекти изградени во овој период имаат полоши топлински карактеристики од оние изградени пред земјотресот." Топлинските загуби се проценети и до 300 $\mathrm{kWh} / \mathrm{m}^{2}$ a. Покрај армирано-бетонскиот скелетен систем од кули и блокови кој масовно се користи околу 70-тите години, во Скопје непосредно заради обновата по земјотресот е отворена фрабриката "Карпош" која работи според руска технологија. Овде се работи за монтажен систем од фабрика и вграден на лице место. Составот на фасадниот зид на овој систем е со изолациски слој од 6 см експандиран полистирен вметнат во средината на панелите. Кај овој систем се јавуваат топлински мостови па затоа ефектот од изолацијата е слаб, a ниските внатрешни температури по површината на sидот предизвикуваат кондензација и растеж на мувла. Кондензацијата и влагата ја руинирале состојбата на полистиренот. Загубите на топлина се големи поради лошиот енергетски концепт во овие објекти. Речиси кај сите типови на згради, старите прозори не ги задоволуваат мин U вредности. Крововите се изведени како рамни со мин. изолација која секако е оштетена. Кај многу станбени згради, станарите низ годините самите го фринансирале покривањето, секако поради протекување кај горните катови. Кнежевиќ и Борковиќ (Knezevič и Borkovič 2009:17) експлицитно потенцираат дека "Активностите за зголемување на енергетската ефикасност со зголемена топлинска заштита кај зградите треба да се насочи кај зградите градени пред 1987 г." Со оглед на тоа дека тој период сме иста држава со Р. Хрватска може да се констатира дека овој заклучок и од претходно разгледаните постоечки состави може да важи и за нашите објекти.

3.5 Периодот на градби од 1981г. е поделен на период од 1981-1991г. во рамките на Југославија и период од независноста до денес (1991-2013).

Во 1980 г. донесени се нови услови и усвоен е првиот JUS стандард. Според Комората на овластени архитекти и овластени инжењери (КОАОИ) во 
Павловски (2011) споменато е дека во 1979г е уредбата каде се поставени минималните критериуми на коефициентот на премин на топлината низ надворешните градежни елементи. Николовски во АРК (2011) пропустот во овие случаи го гледа во тоа што стручните лица ја игнорираат пресметката на топлинските мостови и вкупните специфични загуби. Стручните кадри обучени во големите проектантски компании, потребата од изолација ја решаваат со двојни зидови од керамички блок 2х12см со тервол од 5-6 см таканаречени "сендвич" sидови. По прогласувањето на независноста започнува не почитување на пресметките на потребната дебелина и барањата за топлинска изолација. Во нашата земја цели дваесетина години се игнорира бенефитот од употреба на квалитетна и соодветна обвивка на фасада и останати мерки од аспект на енергетска ефикасност. Денес повторно е актуелизиран проблемот на глобално ниво. Штрбац (2011) истакнува дека на територијата на цела поранешна СФРЈ, периодот на градби од 1950 - 1980 се карактеризира со објекти кои трошат преку $200 \mathrm{kWh} / \mathrm{m}^{2}$ a. Оваа констатација може слободно да и се припише на нашата земја со оглед на заедничкото минато.

\section{4. Анализа на состојбата на постоечките згради со нивните енергетски карактеристики}

\section{1 Видови и извори на енергија}

Според Проактива (Proaktiva 2007) енергијата е апстрактен фундаментален поим кој дејствува врз сите сфери на животот. Според физичарите енергијата не згаснува, само се трансформира. Енергијата врз која се базира функционирањето на денешницата, ја делиме на :

•примарна енергија (добиена од енергенсите од природата)

-секундарна енергија (преработена од примарната)

Со помош на различни уреди и машини доаѓа до трансформација на енергијата. Истата може да биде од необновливи и обновливи извори. Во градежништвото необновливи извори кои се неопходни за добивање топлотна и електрична енергија се: јаглен, нафта, природен гас. За разлика од нив обновливите извори се вечни, како на пример: сончевата енергија, енергијата од ветровите, водите, геотермалната енергија, енергијата добиена од биомаса. 


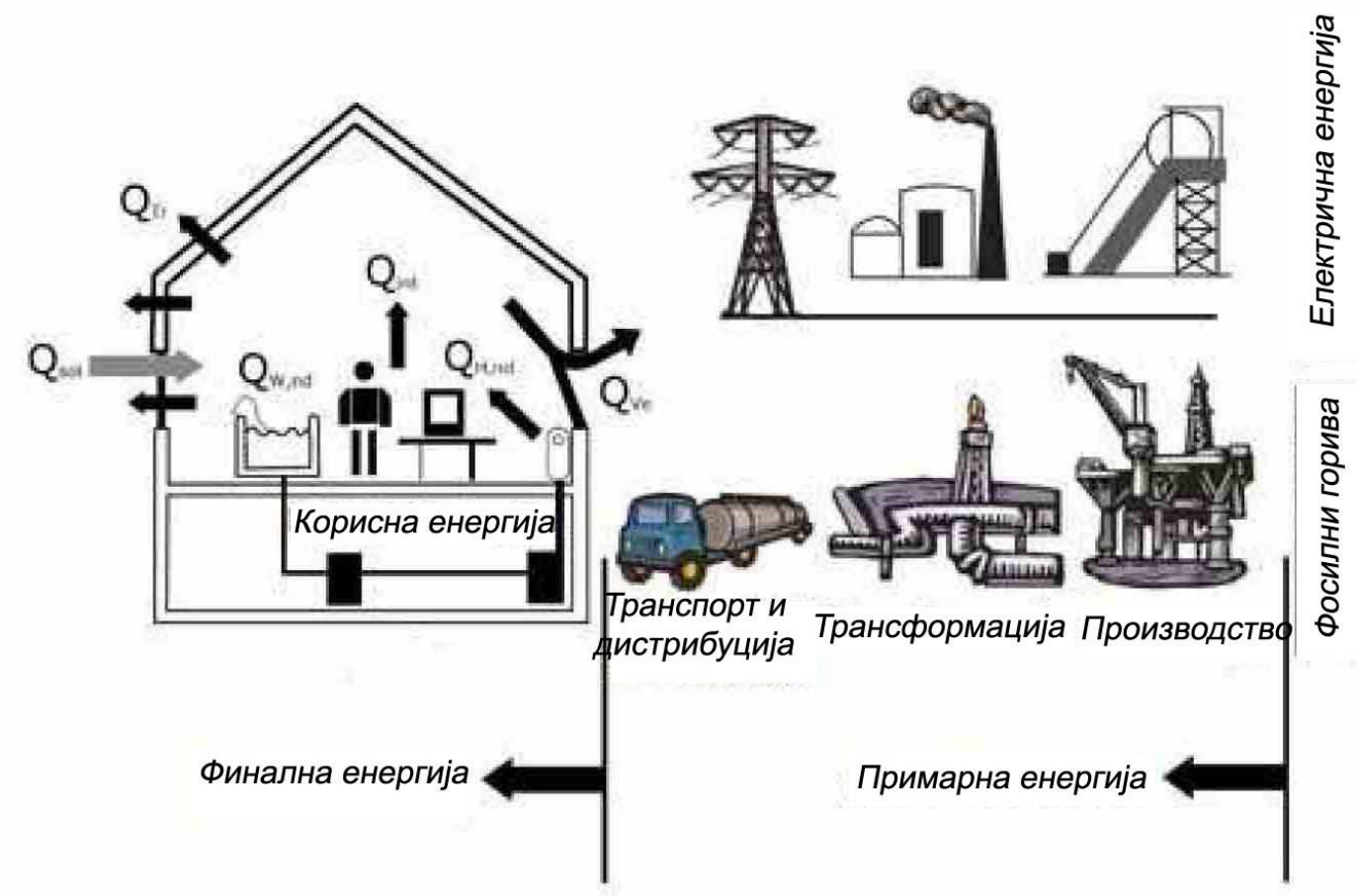

Фигура 4: Приказ на претварање на енергијата - од примарна до корисна

Извор:Штрбац (2011:18)

4.2 Потрошувачка на енергија во зградите (енергетски биланс)

Градежните објекти во поглед на конзумирање и потрошувачка на енергија треба да се анализираат и функционираат како систем. Со видување и пресметување на енергетскиот биланс ги добиваме годишните добивки и загуби за потребна енергија на зградите. Штрбац (2011) ги прикажува основните поими за потрошувачка на енергија :

-топлотни добивки и загуби - (фигура5)

•коефициенти на премин на топлина - U ( изразена во [ $\left.\mathrm{W} /\left(\mathrm{m}^{2 \circ} \mathrm{K}\right)\right]$ )

•степен ден на греење *

Хенсен и др. (Hensen et al. 2004) во истражувачкиот приод на софртверски пресметки за енергетскиот аудит, истакнува дека при истите софртверски симулации "лекувањето" на зградите е најдобро планирано доколку превземените мерки се анализираат како еден целосен ентитет, а не како засебни подсостави кои не се во можност да создадат систем во функција. 


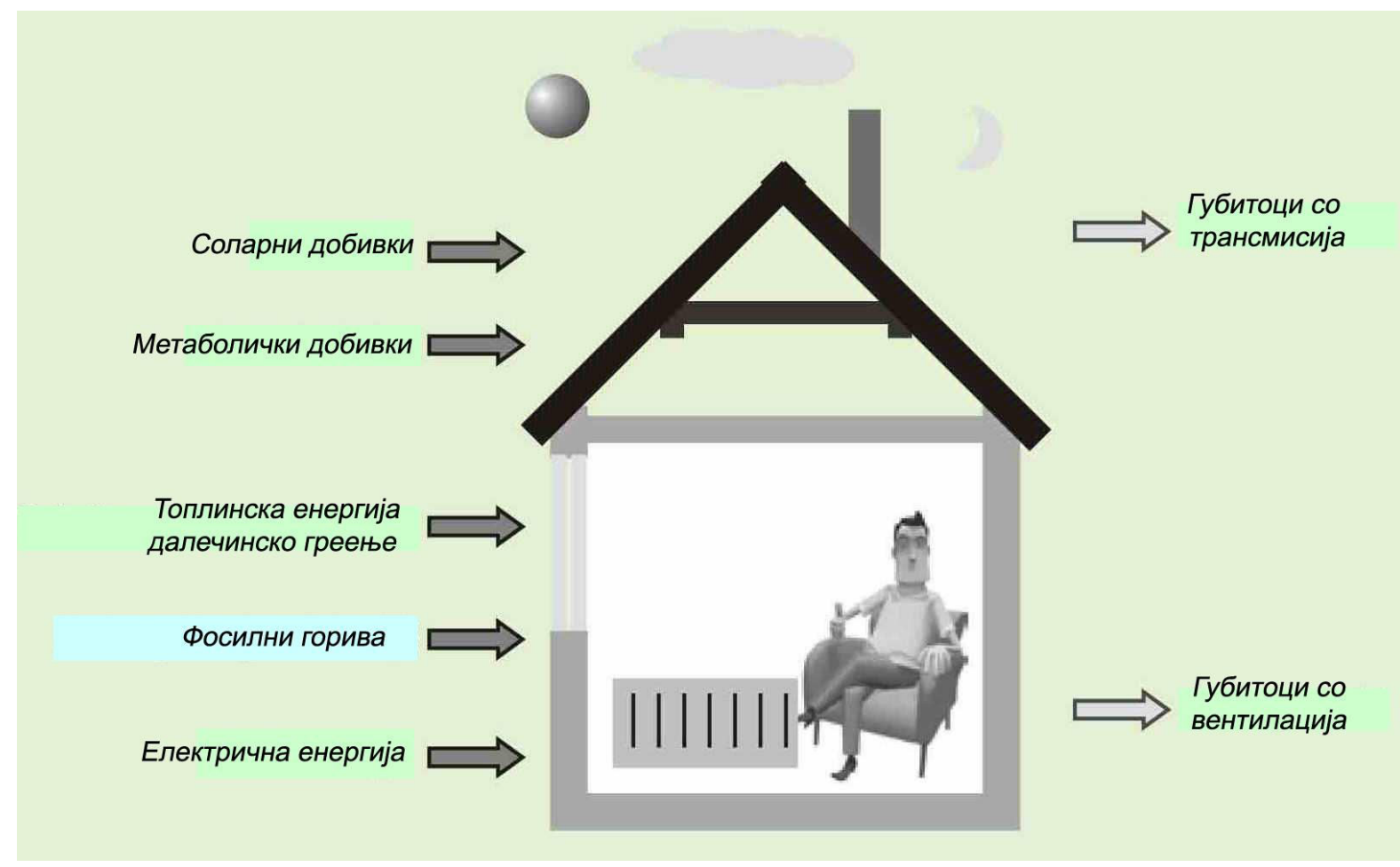

Фигура 5: Енергетски биланс на зграда Извор: Морвај и др.(Morvaj et al. 2010:26)

Бидејќи $70 \%$ од потрошувачката на енергија оди на топлинската енергија вредно е да се напомене дека истата зависи од составот и перформансите на самата зграда. Потребата за довод на топлотна енергија зависи и од загубите на истата. Истите загуби на енергија ќе бидат поголеми или помали во зависност од материјалите кои се вградени во објектите, факторот форма на зградата и видови на енергетски системи кои функционираат во самата зграда. "Една од карактеристиките на целокупниот станбен и деловен простор во Република Македонија е нерационалната потрошувачка на сите видови енергија..." - Спасиќ (2010:23). Тој образложува дека брзиот развој на изградба во 60-те и 70-те години денес резултира со објекти кои се регистрирани како големи потрошувачи на енергија. Истите треба систематски да се реконструираат - модернизираат. Во своите публикации, Спасиќ (2010) ги анализира топлинските загуби на енергијата за греење во просечно изолирани згради и воедно заклучува дека потребите за топлинско греење се со потрошувачка на енергија од $80-90 \%$ од вкупната потребна енергија за објектите. 


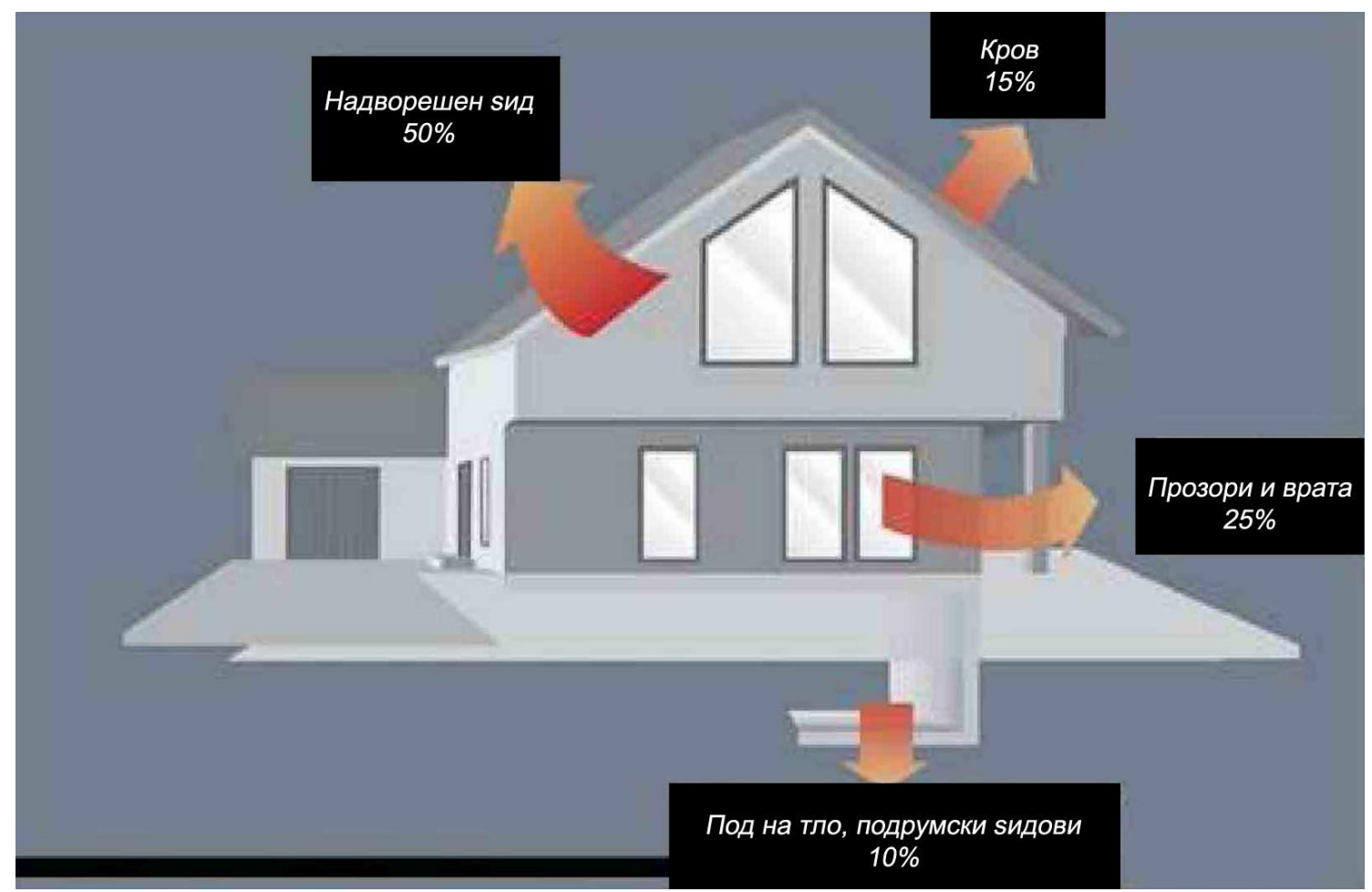

Фигура 6: Топлотни загуби кај објектите Извор: Штрбац (2011:19)

Умешноста на поимот енергетската ефикасност е модел на штедење на енергија, функционирајќи со непречен комодитет, одговорно кон општеството. Топлинските загуби се делат на трансмисиони и вентилациски загуби на енергија. Првите ја преминуваат топлината со трансмисија низ елементите на обвивката на зградата бидејќи енергијата преоѓа од потопла кон поладна средина. Вентилационите загуби зависат од бројот на измени на воздухот заради проветрување на просториите. Морвај и др. (Morvaj et al. 2010) образложува дека под енергетски биланс на зградите се подразбираат енергетските загуби и добивки во истите (фигура 5). При тоа вообичаено се зборува за топлинската енергија, всушност колкава енергија изразена во $\mathrm{kWh} / \mathrm{m}^{2} \mathrm{a}$ - (киловат-часови на еден метар квадратен потрошувачка на енергија за греење на годишно ниво) е потребна за да се задоволат топлинските потреби. Покрај загуби на топлинска енергија во зградите постојат и т.н. слободни топлински добивки (луѓе, електрични уреди за домаќинството и т.н.) Се додека топлинските загуби се изравнуваат со топлинските добивки во зградите ќе се одржуваат сакани услови за топлински комфорт. Од тука Морвај (Morvaj et al. 2010) овие количества на енергија ги дефинира по формулата: 
Q + Qin +Qsun = Qtrans + Qvent + Qgg

Каде што:

$$
\begin{aligned}
& \text { Q = примарна енергија за греење на просторот } \\
& \text { Qin = внатрешни топлотни добивки } \\
& \text { Qsun = топлински добивки од сонце } \\
& \text { Qtrans = трансмисиски загуби } \\
& \text { Qvent = вентилациски загуби } \\
& \text { Qgg = загуби во составот на греење }
\end{aligned}
$$

Многу е важно да се анализира потребната енергија за греење. Таа ќе зависи од повеќе фрактори:

-Топлински загуби низ надворешната обвивка на зградата

-Топлински загуби низ линиските топлински мостови

- Топлински загуби низ точкастите топлински мостови

-Топлотни загуби према тло

-Топотни загуби према негреани простории

-Топлотни загуби од застаклени површини

-Топлотни загуби од вентилација ( проветрување)

•"Слободни" топлински добивки

Постојат и други одлучувачки фрактори од кои ќе зависи структурата на потрошена енергија. Еден од нив е климатскиот фактор. Морвај и др. (Morvaj et al. 2010) прикажува дека во зависност од климата, топлинскиот учинок на енергија за греење ќе изнесува од 30-60\%, додека учинокот на енергија за ладење во зависност од климатскиот фрактор изнесува 3-15\%.

Факторот на форма на зграда е исто така битен за одредувањето на загубите на енергија за греење. Тоа е односот помеѓу вкупната површина на обвивката на зградата низ која се губи топлината - "А" и греениот волумен на зградата "Ve" кој што обвивката на зградата го затвара. Фактор форма на објект може да биде компактен или разгранет во зависност од видот и фрормата. Компактите фрорми повеќе ја задржуваат топлината, додека разиграните и разгранети форми на објекти имаат поголем одлив на топлотна енергија т.е. се енергетско неефикасни.

$$
\begin{aligned}
& \text { fo }=A \text { / Vе изразен во } \mathrm{m}^{-1} \\
& \text { fo }=\text { фрактор фрорма }\left[\mathrm{m}^{-1}\right]
\end{aligned}
$$


$\mathrm{A}=$ обвивка на зграда $\left[\mathrm{m}^{2}\right]$

$\mathrm{Ve}=$ бруто греан волумен на зграда $\left[\mathrm{m}^{3}\right]$

Колку вредноста fo e помала, толку зградата e покомпактна. Понатаму потрошувачката на енергија и емисиите на СO2 зависат и од изградбата, структурата на објектот, квалитетот на изолација како и однесувањето и културата на крајните корисници. Според Правилникот на Општина Карпош(2012) објаснети се одредени дефиниции:

A = обвивка на зграда $\left[\mathrm{m}^{2}\right.$ ] е вкупна надворешна површина на зградата (sидови, покриви, м.к.к. под и над греан простор, еркери, отвори, хоризонтални и вертикални конструкции вкопани во терен) низ кој топлината се пренесува кон надворешноста, пресметана во согласност со стандардот МКС EN ISO 13789.

$\mathrm{Ve}=$ бруто греан волумен на зграда $\left[\mathrm{m}^{3}\right]$ е волуменот на зграда затворен со надворешната обвивка, пресметан со надворешни димензии, во согласност со стандардот МKC EN ISO 13789. За поедноставна пресметка може да се примени $\mathrm{V}=0.8 \mathrm{Ve}\left(\mathrm{m}^{3}\right)$.

Степен ден претставува разлика меѓу внатрешна проектна температура и средна надворешна проектна температура во грејна сезона, помножена со број на денови за греење.

Од потрошувачката на енергија се крие и основната идеја за енергетска ефикасност во градежните конструкции. Со енергетска ефикасност се намалува потребата на енергија за греење. Всушност се намалува влезната енергија како и нејзините загуби, а при тоа не се нарушува комфорот и амбиентот во просторот."Енергетска ефикасност е континуиран процес и не завршува со имплементација на мерките за подобрување, туку продолжува преку пратење и потврдување на отстварените заштеди, откривање на нови потенцијали, имплементација на нови мерки на подобрување на енергетска ефрикасност, ито се заедно води кон целосно и континуирано управување со енергuјата." - Морвај и др. (Morvaj et al.2010:15) 


\section{3 Емисија на СО2}

Потрошувачката на фосилните горива и енергија која се употребува за загревање на домот секако ја пратат стакленичките гасови и емисија на јаглероден диоксид. Количината на СО2 која ја емитува една зграда ќе зависи од типот на енергентот кој се користи. Кога се работи за нов или реконструкција на постоечки објект, главна цел е, покрај заштедите на енергија според националните регулативи да се запази и намали ова емитување. Според Спасиќ (2010) овој фрактор е од најголема важност за заштита на природата што земјите во своите правилници и регулативи (потписниците на Кјото протокол) ја имаат јасно дефинирано крајната граница, начини и намалувања на стакленичките гасови.

"Емисијата на стакленички гасови е одговорна за глобалното затоплување и може да има драматични економски и социјални последици врз животната средина на глобално ниво."- Државен завод за статистика (2011). Истите истакнуваат дека најголем извор на CO2 до 78\%, претставува секторот за енергија.

ЕМИСИЈА НА СО 2 ВО СЕКТОР ГРАДЕЖНИШТВО ВО ЕУ

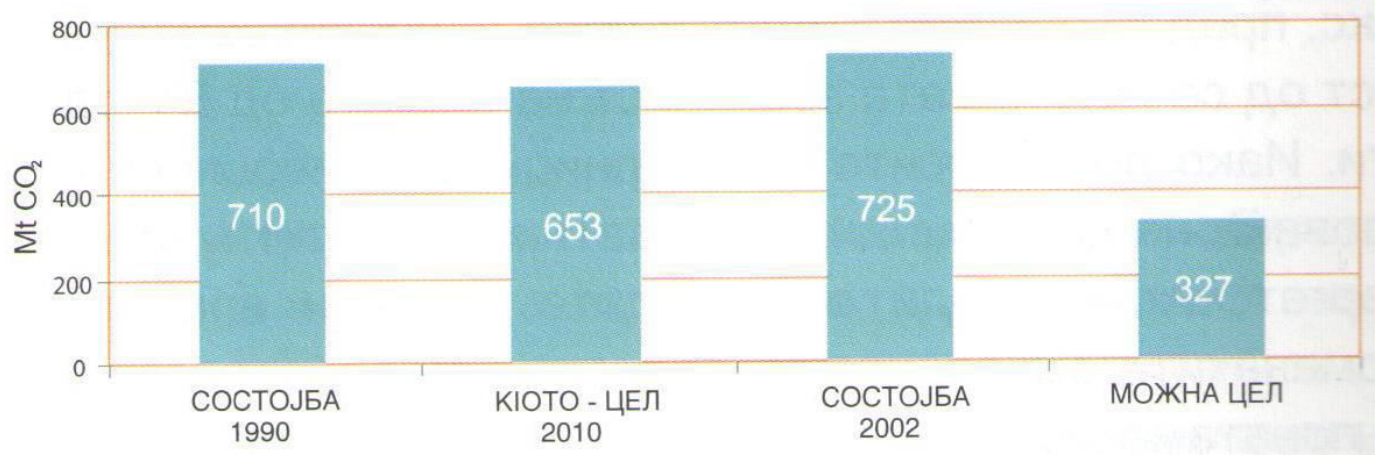

Фигура 7: Емисија на СО2 во сектор градежништво во ЕУ Извор: Спасиќ (2010:20) 
4.4 Критични позиции и фрактори кој влијаат на енергетската (не) ефикасност на градежните конструкции
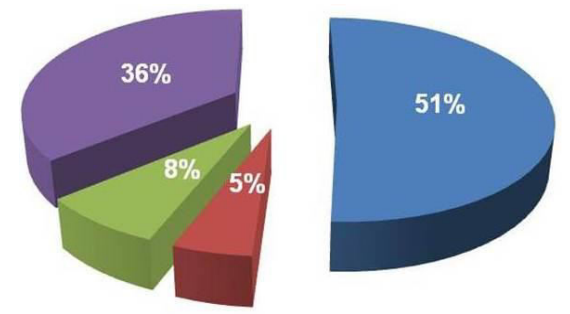

$51 \%$ Недоволно внимание посветено по прашањето трајност за време на изведување на објектите.

5\% Нередовно одржување или неодржување за време на употреба на објектите.

8\% Неправилен избор на материјалот со кој е изграден објектот

(36\% Недоволно внимание посветено на трајноста во самото проектирање.

Фигура 8: Причини за прерано дотраени конструкции

Извор: Миловановиќ (Milovanovič 2012:9)

Преку $60 \%$ од зградите во Европа се постари од 30 години, а истите се изведени со лоши енергетски стандарди пред појавата на нафтената криза. Република Македонија има голем процент на згради кои се со старост од 40 години и просечна потрошувачка на енергија од $200-300$ kWh/m² - годишно. Како што е спомнато во поделбата на типови на конструкции во зависност од периодот на градба, може да се истакне дека кај нас најпогодни за енергетска санација и модернизација се оние станбени згради кои се градени околу 19701980 г. Истите се покажале со најголема потрошувачка на енергија за греење и многу слаби енергетски перформанси. Секако зад оваа состојба се кријат многу фактори и критични точки уште во самиот начин на не превземање енергетско ефикасни мерки при проектирање, како не вложување во квалифицирани работници и мајстори, изведување (притисок врз роковите на изведба, лоши материјали), а не изостанува и начинот на третирање на зградата од самите корисници или сопственици. Оваа состојба во која се наоѓаат постоечките згради, денес е не одржлива. Со енергетско обновување ќе се добие огромен потенцијал за енергетска заштеда, а со тоа и можност за осовременување на 
стручниот кадар почнувајќ од главните мајстори, архитектите-проектанти се до изведувачите. Нискоенергетската и пасивната градба се дел од современата архитектура. Во класичното образование не се посветувало многу внимание на енергетска ефикасност, ниту во Република Македонија се едуцирале мајсторите за практична изведба од овој тип. Можеби ова прашање претставува и клучен проблем за да добиеме краен енергетско ефикасен производ. Сепак Николовски (2011) образложува дека постои еволуција на критериумите за топлинска изолација на згради. Критериумите се однесуваат на начинот на поставувањето и дебелината на изолацијата.

На пример:

1.Во седумдесетите години од минатиот век

Дебелината на изолациониот слој на надворешен sид изнесува д=2-4cм.

Изолациониот материјал е со "к"(U) вредност на зидовите околу 1,20 W/m2

2.Во осумдесетите години

Дебелината на изолациониот слој изнесува д=4-6см. Изолациониот материјал е со "к"(U) вредност на зидовите околу $0,90 \mathrm{~W} / \mathrm{m}^{2}$.

Според Миловановиќ (Milovanovič н.п.) постојат неколку критични точки во изведбата кај постоечките згради кои низ годините метастазирале, го оштетуваат животниот век на објектот и лошо влијаат врз енергетската ефикасност. Поважни проблеми кои треба да се увидат се:

- Недоволно изолиранње на обвивката на зграда

- Влагата

- Влијанието на топлинските мостови

- Несоодветно вградена и дотраена изолација

- Дотраеност на прозорите и вратите на фрасада

- Не изолирани и оштетени кровови и рамни тераси

- Подови над негреани простори, подови на тло, балкони, останато... 


\section{-Влага}
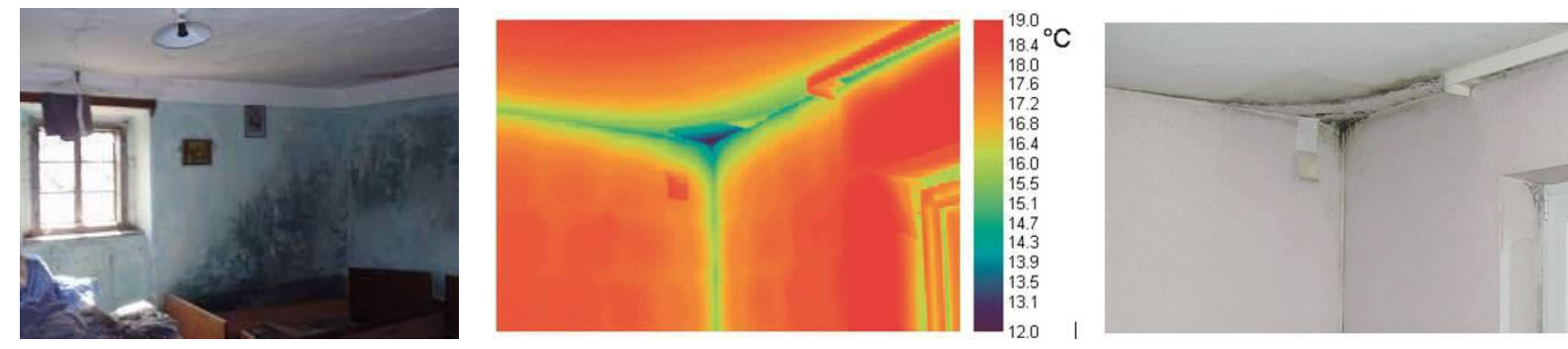

Фигура 9: Влага - квалитет

Фигура 10: топлински мостови

Извор: Миловановиќ (Milovanovič 2012:13-20)

Градежниот објект може да се влажи од: влага во темелите, атмосферска влага и пародифузија. Според Миловановиќ (Milovanovič н.п.) влагата претставува голем причинител за уништување на градежните конструкции.

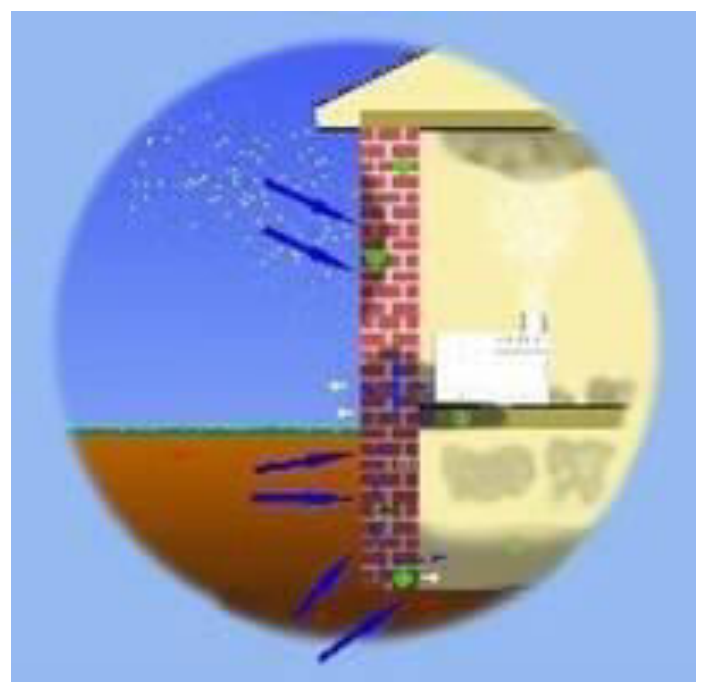

Фигура 11: Влага - квалитет

Извор: Миловановиќ (Milovanovič 2012:13)

Неправилното третирање на топлинските мостови кај градежните конструкции создава појава на мувла, корозија или пропаѓање на материјалот. Напоменува дека студиите покажале дека $70 \%$ од проблемите во зградите ги создава влагата. Водената пареа навлегува во материјалот со дифузија или како капиларна влага. Од тука пародифузниот отпор на материјалот ќе зависи од структурата и порозноста на истиот истакнува Магаш (Magaš н.п.). Овој процес Миловановиќ (Milovanovič н.п.) практично го прикажува кај незаштитените и руинирани изолации вградени во објектите. Доколку во просториите воздухот има поголема релативна влажност од 60\%, при преминот низ надворешните 
конструкции истиот има голема количина на водена пареа која се впива во материјалот или изолацијата на зидот. Во моментот кога водената пареа ќе се олади во топлинската изолација, т.е. ако падне под точката на оросување таа ќе кондензира. Овој процес предизвикува уништување на самата изолација и влажнење на материјалот. Кога температурата кај надворешните конструкции е пониска од температурата на внатрешниот воздух има услови за создавање на кондензација. Во зоната кај топлинските мостови, температурата е уште пониска и ако падне под точката на оросување, настанува површинска кондензација со можност за растеж на мувла истакнува Николовски (2012). Тој објаснува дека во сите законски регулативи во ЕУ ваквата состојба е недозволива, всушност преземени се мерки за заштита и отстранување на мувлата. Мувлата покрај тоа што ги уништува фриналните површини на градежните елементи, истата претставува и опасност по човековото здравје. На овие места настанува забрзано таложење на честички од прав. Колониите на габички брзо се шират на фринално обработените површини. Покрај естетскиот недостаток, човекот вдишувајќи ги овие габички - мувлата може да си го наруши здравјето. Мувлата предизвикува главоболка, иритација на грло и нос, ринитис, алергии дури и астма. Токму топлинските мостови кои од кондензацијата ја обезбедуваат влагата на површините од sидовите, ја обезбедуваат средината која ќе e плодно тло за фрормирање на микроорганизми, габички, мувла. Со третирање и модернизација на постоечките станбени згради се намалува влијанието на топлинските мостови кои се едни од причинителите за настанување на синдромот на болни згради. Според USEPA (1991) терминот "синдром на болни згради" ("sick building syndrome"), најмногу се дефинира од квалитетот на внатрешниот воздух кој може да предизвика одредени болести на оние кои престојуваат во објектите. Со тоа се става акцент и на заштитата на човековото здравје. 


\section{-Влијанието на топлинските мостови}

Топлинските мостови претставуваат делови од градежните конструкции каде што топлинскиот проток е зголемен заради промена на материјалот во делови од конструкциите, дебелината или геометриската форма на градежните делови. Николовски (2012) посветува научно истражување на топлинските мостови во градежните конструкции и сите причинители низ времето на истите. Тој потенцира дека не постои објект без топлински мостови, но целта на оваа проблематика е од "малигни" да преминат во "бенигни" состојби. Зимно време во оние делови од конструкциите каде што топлинските протоци се зголемени, а како резултат на тоа температурите на внатрешните површини (топлинските мостови) се намалени доаѓа до процес на кондензација која резултира со мувла и нездрав амбиент. Топлинските мостови се делат на еднодимензионални, дводимензионални, тродимензионални. Најновата европска Директива 2010/31/EU која се однесува на енергетски перформанси на згради има воведено каталози и атласи за полесно решавање на оваа проблематика. Но Николовски (2012) проблемот во овие готови решенија го гледа во тоа што истите се безполезни за нашите региони каде владеат строги критериуми за сеизмички градби. Масовната употреба на армираниот бетон во нашите региони ги прави овие готови каталози нефункционални. Прописите за сеизмичко градење претставуваат минимално потребна заштита на човекот и материјалните добра и почнуваат со примена во Европа непосредно по Скопскиот земјотрес 1963г. Обврската на земјите кои се во сеизмички региони е да ја усогласат регулативата за енергетска ефикасност и да се придржуваат кон неа заедно балансирајќи ја масовната употреба на градби кои бараат сеизмичка стабилност. Поточно треба да се најде баланс помеѓу енергетска ефикасност и сеизмичка стабилност. Топлинските мостови се делови од обвивката на зградата кои што не се коректно изолирани - фигура 12. 


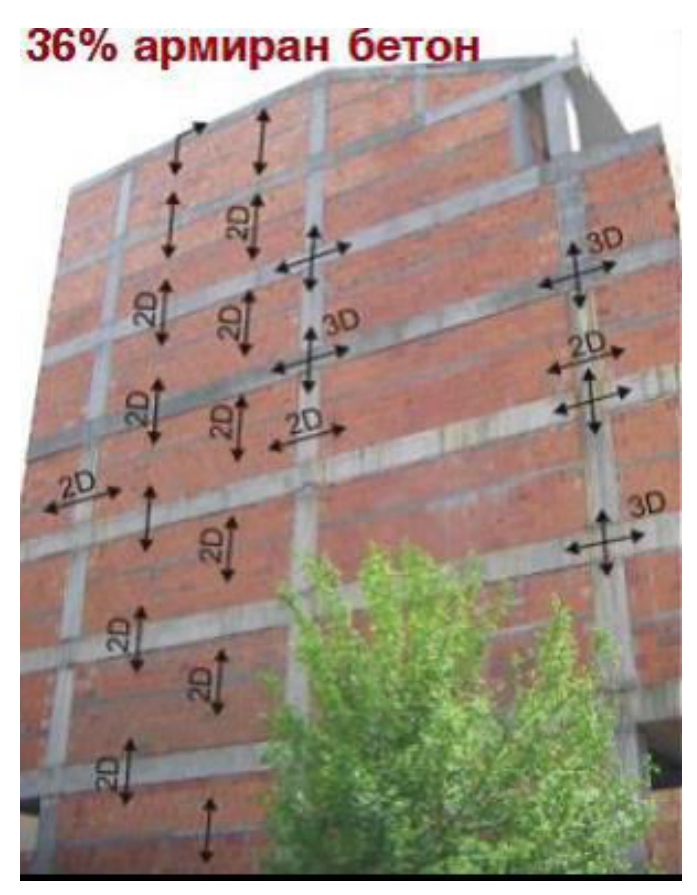

Фигура 12: Топлински мостови на згради во фраза на градба Извор:Николовски (2012:171)

\section{- Несоодветно вградена и дотраена изолација}

Ниската цена на фосилните горива во минатото како и пониските трошоци за енергија во домаќинствата биле една од главните причини заради што не се обрнувало внимание за соодветно заштитување и изолирање на обвивките на згради. Се до конференцијата на ООН (Friends of the Earth н.п.) за светскиот самит, малку се посветувало внимание на влијанието и негативните последици од потрошувачката на енергија, и заштита на екосредината. Во нашите региони голем дел од постоечките згради како што е погоре споменато воопшто не се изолирани. По воведувањето на првите стандарди за изолирање и термозаштита на градежните конструкции (79-80год), започнува имплементација на мерките за енергетска ефикасност но изведбата покажува многу недостатоци. Денес тие недостатоци се детектирани како: влага, мувла, топлински мостови и сл. Главниот проблем на оваа состојба се гледа во лошата изведба на детали со многу нерешени споеви и вградени инсталации кои всушност треба да претставуваат систем кој функционира без негативни последици. Миловановиќ (Milovanovič н.п.) појаснува дека овој проблем би се совладал само со овластувања на сите инфилтрирани субјекти кои 
учевствуваат во изведбата. Потеклото на лошо вградена изолација Миловановиќ (Milovanovič 2012) го објаснува преку фигура 13(а,б,в,) и фригура 14.

a)

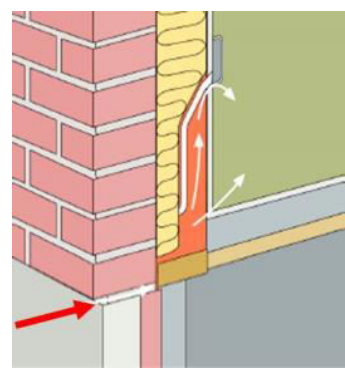

б)

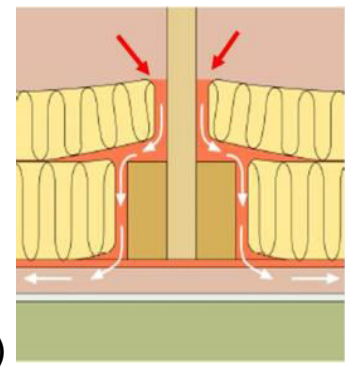

B)

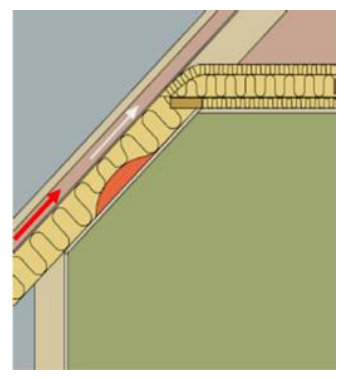

Фигура 13: а) Присутност на електични инсталации

б) Лошо вградување

в) Присутност на електрични инсталации

Извор: Миловановиќ (Milovanovič 2012:22)
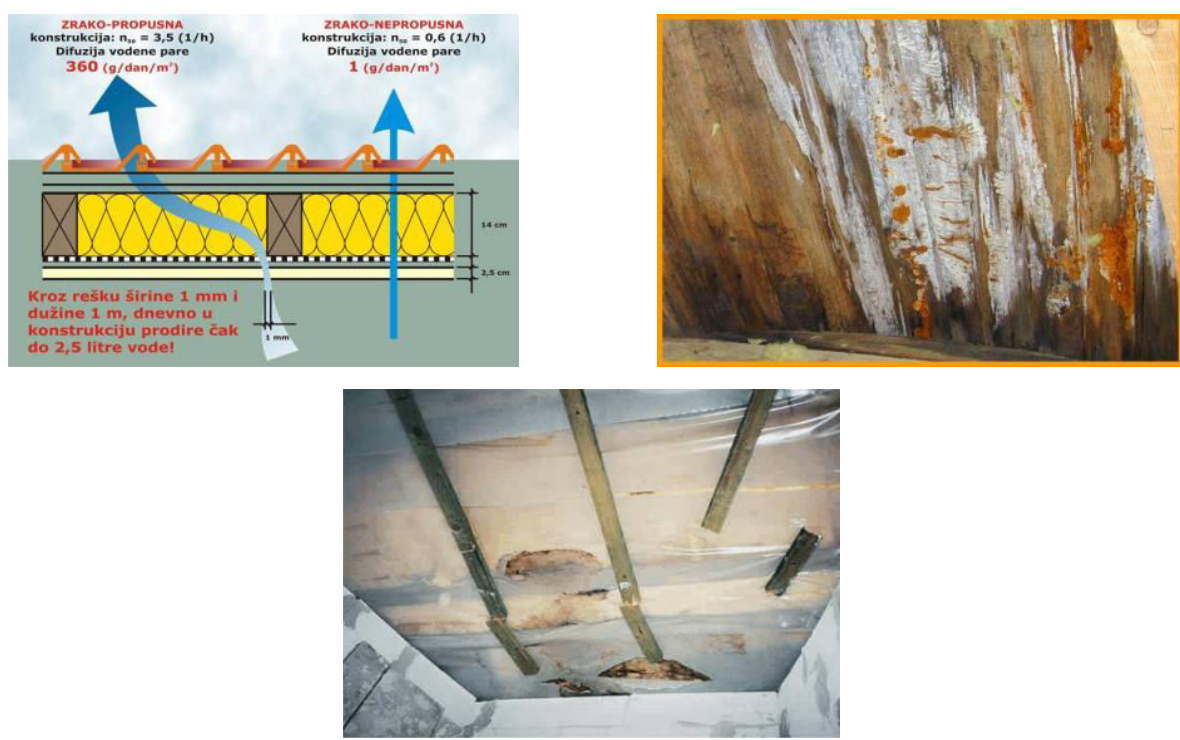

Фигура 14: Влез на водена пареа преку градежните конструкции Извор : Миловановиќ (Milovanovič 2012:24-25) 


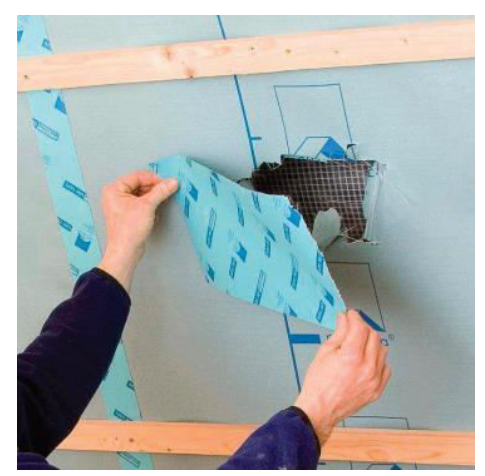

Фигура 15: Херметичко затварање користејќи траки и профили

Извор : Миловановиќ (Milovanovič 2012:29)

Потекло на лошо и нестручно изведени подобрувања на изолација. Примена на неквалитетни материјали и изолација која не е вградена во систем, нестручна опрема и работна сила доведува до лоша изведба и руинирање, образложува Миловановиќ (Milovanovič 2012) кај фригура 16 и 17.

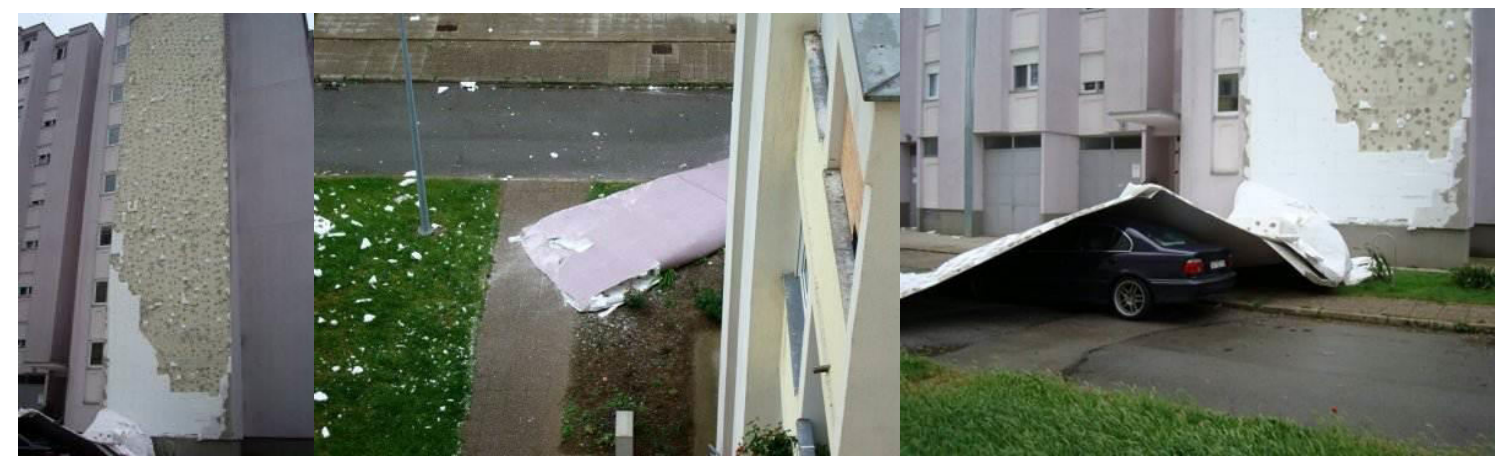

Фигура 16: Нестручно изведени подобрувања на фрасада користејки неадекватни материјали и технологии (ул. Домовинског рата - Вуковар) Извор: Миловановиќ (Milovanovič 2012:8)

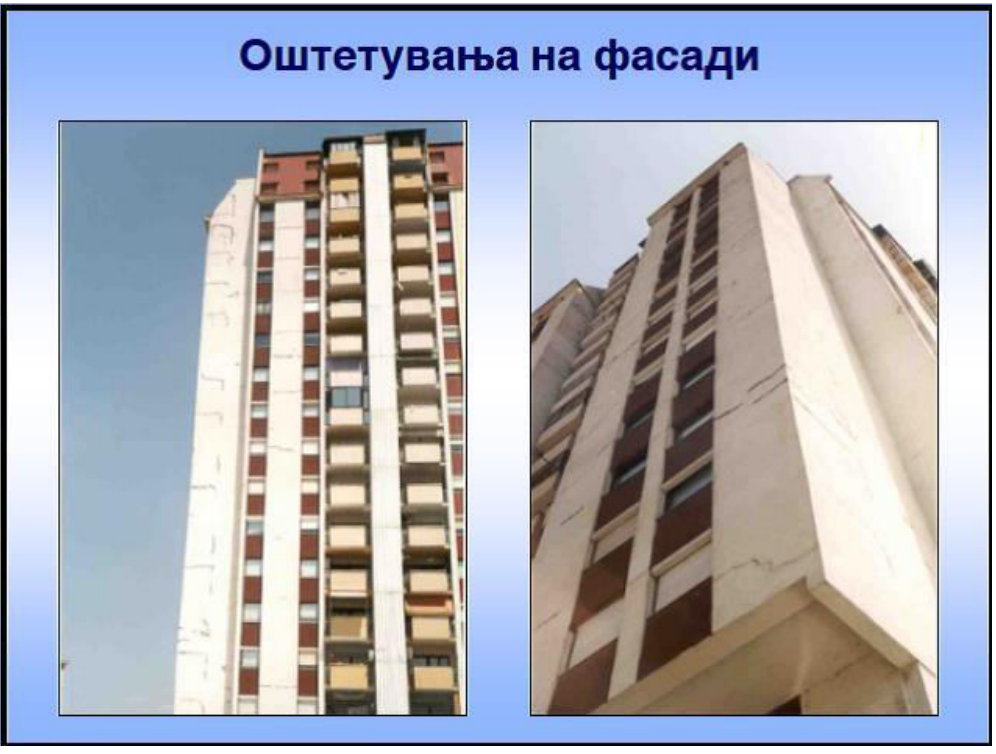

Фигура 17: Кули во Карпош - несоодветно изведена фасада

Извор: Николовски (2011:5) 
- Недоволно изолирње на обвивката на фасада

Недоволно изолирани фрасади со термичка изолација и воопшто неизолираните објекти не само што се енергетски неефикасни туку, претставуваат следен проблем. Тоа го објаснува Шкоро (Śkoro 2010) појаснувајќи ги причините и последиците од градежни објекти кои немаат термо обвивка. Недоволната термичка изолација го доведува објектот до поголеми топлински загуби во периодот на зимата, ладни надворешни конструкции, оштетувања кои настануваат како последица на влага во внатрешните простории, прегрејување на просторот во летните периоди. Последиците од неизолираните објекти со термо обвивка се со поголема потреба од количевство на енергија за греење, поголеми режиски трошоци, нездрава средина, нездраво живеење, загадување на природната околина која пак повратно ќе делува на загадување и оштетување на објектите и здравјето на луѓето.
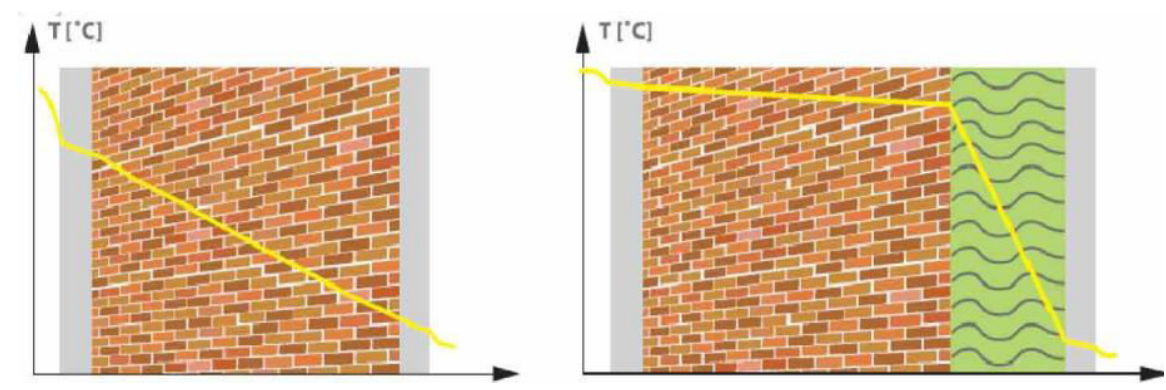

$\mathrm{U}=1.67 \mathrm{~W} / \mathrm{m}^{2} \circ \mathrm{K} \ldots 134 \mathrm{kWh} / \mathrm{M}^{2} \circ \mathrm{a} \quad \mathrm{U}=0.32 \mathrm{~W} / \mathrm{m} 2 \circ \mathrm{K} \ldots 26 \mathrm{kWh} / \mathrm{M}^{2} \circ \mathrm{a}$
Фигура 18: Сид од тула, потрошувачка на енергија за греење без и со изолација Извор: Кнежевиќ и Борковиќ (Knjezevič I Borkovič 2009:20)

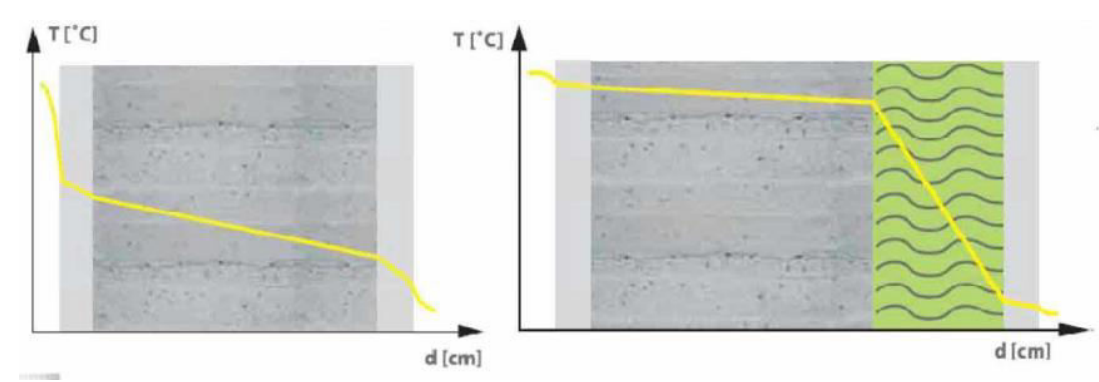

$\mathrm{U}=3.20 \mathrm{~W} / \mathrm{m}^{2} \circ \mathrm{K} \quad \ldots 256 \mathrm{kWh} / \mathrm{M}^{2} \circ \mathrm{a} \quad \mathrm{U}=0.35 \mathrm{~W} / \mathrm{m} 2 \circ \mathrm{K} \ldots .28 \mathrm{kWh} / \mathrm{m}^{2} \circ \mathrm{a}$ Фигура 19: Зид од армиран бетон, потрошувачка на енергија за греење без и со изолација Извор: Кнежевиќ и Борковиќ (Knjezevič I Borkovič 2009:20) 
- Дотраеност на прозорите и вратите на фасада

Башиќ и др. (Bašiš et al. 2008) ја презентираат загубата на топлината кај старите прозорци која е 10 пати поголема отколку кај sидовите. Загубите низ прозорците се делат на трансмисиски загуби и загуби со вентилација. Ако се соберат овие загуби, вкупните топлински загуби низ прозорците ќе изнесуваат $50 \%$ од сите топлински загуби во зградата. Со термографска снимка може да се види како изгледа загубата на топлината кај прозорците. Истата ќе биде поголема кај стаклото, а помала кај рамките иако се стари. Обичното стакло лесно ја спроведува топлината кон постудената страна, на пример во зима кон надвор, а со тоа се губи големо количевство на енергија. Овој елемент на фасадата е од големо значење при санација на еден објект бидејќи, најголем дел од загубата на енергијата минува низ него. Кај постарите објекти најчесто прозорците се во лоша состојба. Вредноста $U$ кај старите прозорци, според инжењерите за термотехника е усвоена како $U=3-3,5 \mathrm{~W} / \mathrm{m}^{2} \circ \mathrm{K}$ истакнува Башиќ и др. (Bašiš et al. 2008). Просечната топлинска загуба на овие делови на годишно ниво изнесува 240-280 kWh/m². Усвоената мах вредност U, според Правилникот на Општина Карпош (2012), треба да изнесува $U=1,7-2 \mathrm{~W} / \mathrm{m}^{2} \circ \mathrm{K}$. При замена на постоечките - стари прозорци и врати на фасада, искуството покажува дека треба да се анализираат повеќе аспекти и тоа:

- Изборот на рамката и коефициентот U на спроводливост на материјалот.

- Изборот на стакло пакетот ( двослоен, трослоен, исополна со благороден гас, коефициентот $U$, влијанието на релативна влажност на воздухот, пропустливост на светло, соларна контрола, звучна изолација ... )

- Монтажата да биде соодветно изведена и контактот со фасадата да биде изведен на начин со кој ќе се намалат топлинските мостови.

Важно, во овој дел од градежните конструкции е, при реновирање на постоечки објекти, да се применат технологии кои ќе ја искористат сончевата енергија како обновлив енергетски ресурс. 
- Неизолирани и оштетени кровови и рамни тераси

Доколку кровот не е изолиран, низ овој градежен елемент се губи околу 15-30\% (кров 15\%, оџак $30 \%$ ) на топлина истакнува Штрбац (2011). Ако просторот под овие површини е искористен за домување, во овие станбени простории има најголеми топлински загуби во текот на зима и високи прегрејувања во лето. Чести проблеми со влага и топлински мостови не се исклучок, што го прават квалитетот на живеење многу полош од останатите катови во зградата. Сепак треба да се напомене дека подобрувањето на оваа состојба е достапна од технички причини, а воедно и има повраток на средствата т.е. е економски оправдана. Рамните кровови се многу изложени на атмосферски влијанија. Тие може да бидат непроодни, проодни, зелени кровови. Од голема важност ќе биде состојбата на хидроизолација, термоизолација, и сливниците за атмосферски води.

•Подови над негреани простори, подови на тло, балкони, останато...

Подовите кои се наоѓаат над негреани простори како подруми, визби и сл. имаат значаен премин на топлина во зимските периоди. Тие лесно се изолираат од страна на плафонската плоча од подрумите. За реконструкција на подот кој е директно на тло потребни се поголеми инвестиции поради реконструкција на целиот состав на подот и кај постоечките згради обично е неисплатлива. Овие конструкции се разликуваат од претходните по носивата бетонска плоча и хидроизолацијата која им е вградена. Загубите на топлина, според Штрбац (2011) се проценуваат на $10 \%$.

Балконите се значаен фактор кој влијае врз енергетските карактеристики на еден објект. Би требало да се изолираат или опшијат со фасадна изолација со што би се спречиле загубите кои се јавуваат во критичните точки а тоа е спојот со надворешниот sид. При реконструкција на старите згради во западноевропските примери приложени во Феист (Feist 2010), има случаи на отстранување на балконите и поставување на монтажно - демонтажни балконски елементи. 
- Други фрактори кои влијаат на енергетските карактеристики на зградите се :

- Инсталации за греење и нивно изолирање

- Инсталации за греење на топла вода

- Инсталации за вентилација

- Електрична инсталација

- Местоположба, ориентација, клима

- Соларни системи и заштита од сонце

- Природно вентилирање

- Внатрешна микроклима

\section{5.Приод кон санација и модернизација на постоечките згради со имплементирање на енергетско ефикасни мерки.}

5.1 Процес кон приод на санација и модернизација на постоечките згради со примена на енергетска ефикасност

Хазука (Hazucha 2010) приложува дека 90\% од зградите во Европа се изградени пред 1990 година каде според енергетските сертификати спаѓаат во "D" или "F" категорија што значи незадоволително или многу неекономично. Причината за оваа ситуација лежи во фрактот што во минатите години не се внимава на цената на енергенсите која била незначителна, но во денешни услови претставува голем товар на населението и власта, па одтука и го поставува прашањето дали ќе модернизираме? Под санација или реконструкција на старите згради се подразбира превземање на градежни мерки кои ќе овозможат обнова на оштетените делови од структурата на објектот. На пример со воочување на проблемите кај sидови оштетени од влага, ронење на малтер, статичка стабилност и сл. Овие мерки се од суштинско заначење и без претходно санирање на истите не би имало смисла да се започне модернизација со енергетски концепт. Овој приод ќе биде решен само со планско пристапување на проблемот, од енергетски преглед до комплетен проект и надзор врз работите. Потоа може да се анализира состојбата на објектот, како и методологијата на модернизација, од причина што модернизацијата треба да овозможи повраток на вложените средства. Со 
модернизацијата на постоечките градби битно е да се задржат минималните топлински стандарди и стандардите на вградената инсталација. Со еден збор да дојдеме до енергетска ефикасност. Принципите на модернизација кај постоечките станбени згради може да доведат до штедење на енергија, како кај пасивните и нискоенергетските објекти со примена на неколку методи. Со примена на висококвалитетен и континуиран слој на изолација, со елиминација на топлотни мостови, со правилно вградување на прозори и надворешни врати со високи перформанси, примена на механичка вентилација се создаваат можностите за оформување на квалитетна обвивка на зграда и повраток на сретствата.

\section{2 Енергетски преглед на состојбата}

Енергетски преглед на зградите претставува анализа на термичките карактеристики на зградата, анализа на сите технички состави во зградата кои трошат енергија и вода, со цел на утврдување на ефикасноста или неефикасноста на самиот објект. Крајниот резутат треба да даде заклучок за состојбата на зградата од енергетски аспект и со тоа да овозможи издавање на енергетски сертификат кој транспарентно ќе ја прикаже енергетската состојба како и ќе даде препораки за подобрување. Поради утврдување на нијанси и различности при спроведувње на енергетскиот преглед на градбите кај земјите кои се обврзани да издаваат енергетски сертификати, Морвај и др. (Morvaj et al. 2010) образложува неколку методологии. За постоечките објекти, енергетскиот преглед на зградите е прв чекор во собирање на податоци и информации во врска со енергетската состојба и начинот на користење на енергијата, лоцирање на местата каде се троши неефикасно енергијата и ги идентификува мерките за подобрување на енергетската ефикасност. Преку енергетскиот преглед на зградите се сообираат и обработуваат податоци за состојбата на градбите од аспект на:

- Анализа на топлотната карактеристика на обвивката на зградата.

- Анализа на енергетските својства на системот за греење, ладење, вентилација и климатизација.

- Анализа на енергетските својства на системот за електрична енергија. 
- Анализа на енергетските својства на системот за подготовка и потрошувачка на топла вода.

- Анализа на состојбата на сите електрични уреди.

- Начин на користење на зградата и сите енергетски уреди во неа.

Според Министерството за градежништво и просторно планирање (Ministarstva graditeljstva I prostornog uredzenja - MGiPU 2012:5), користа од енергетски преглед на зградите е:

"Анализа на состојбата и можности за примена на мерки за подобрување на енергетските својства на градбите и подобрување на енергетската ефрикасност..."

Во зависност од потребите и целите, енергетскиот преглед на зградите се дели на прелиминарен и детален. Прелиминарниот енергетски преглед кој се одвива за време на разгледување на зградата, служи за да се осознаат основните енергетски својства. Покрај тоа, овој преглед овозможува утврдување на состојбата на зградата и предлог мерки за енергетска ефикасност како и можностите за заштеда на енергија во зградата. Во случај на потреба за издавање енергетски пасош-сертификат, се врши детален енергетски преглед кој има методолошки приод, воведен во посебен Правилник. Кога се врши енергетски преглед кај постоечките згради од голема важност е познавањето на периодот на градбата и материјалите вградени во истата. Термичката состојба на обвивката на фрасада се анализира и се пресметува според одредена методологија, за да се добијат коефициентите на премин на топлина низ градежните материјали и конструкции. Со тоа се добива и потрошувачката на количество на енергија во објектот. За полесно да се одвива овој процес конструирани се прашалници кој служат да се соберат податоците за зградата. Конкретно кај постоечките згради МГиПП (MGiPU 2012) укажуваат дека потребно е да се утврди:

- Да се намали потрошувачката на енергија за греење преку подобрување на обвивката на зградите во целост.

- Да се зголеми ефикасноста на енергетските системи и инсталации (изолација на цевки и сл.)

- Во зависност од условите да се разгледа можност за користење на обновливи извори на енергија. 


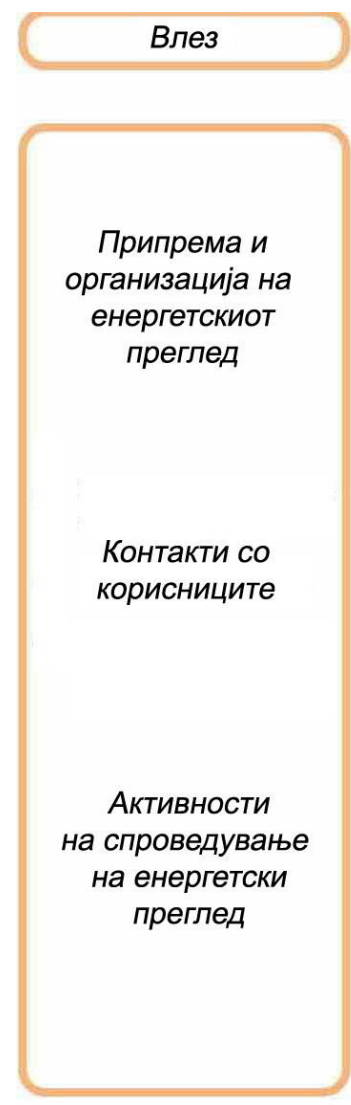

Процес
Обиколка на зградата и дефинирање
на клучните проблеми
Разговори со соодветни лица
за добивање на податоци за водење
и одржување на зградата
Собирање ча трошоци за енергија
(одговорноста е на нарачателот на е.п.)
Преглед на постоечката документација
Потребни истражувања и мерења
Анализа на собраните влезни податоци
Оцена на ЕЕ на објектот
споредба и анализа на потрошувачката
на енергија и вода
Пресметка на енергетскиот биланс
Пресметка на сите вредности
кои треба да ги содржи
енергетскиот сертификат
Сведување на резултатите од пресметката
според начинот на експлоатација на објектот
Вистинските климатски параметри
транспарентна пресметка на топлинската
енергија

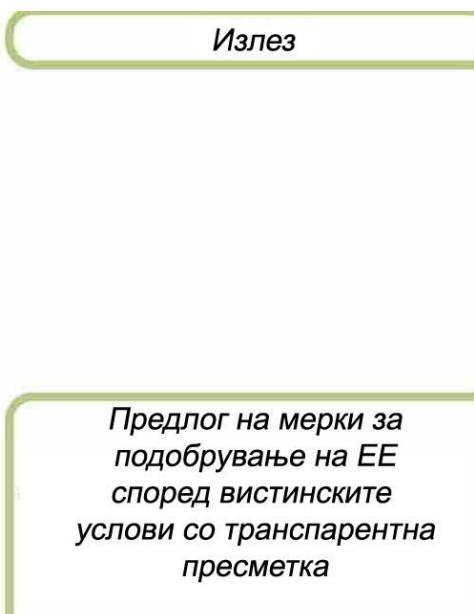

Извештај за енергетски преглед

Енергетски сертификат на згратата

Фигура 20: Текот на извршување на енергетски преглед на градбата Извор : МГиПП (MGiPU 2012:6)

(MPEPZ -Методологија на спроведување на енергетски преглед кај зградите)

Кнежевиќ и Борковиќ (Knezevič и Borkovič 2009) ќе истакнат дека поради различните методологии на изработка на енергетски прегледи, е создадена потреба од единствен документ - форма на изработка на енергетски преглед кој се спроведува со цел на утврдување на енергетските својства на зградите. Сите овие извршени анализи и методологии имаат за цел да укажат дека без детален енергетски преглед и без јасен системски пристап не би имало можност да се изврши гарантирана заштеда со превземање на било какви енергетско ефикасни мерки. Во едно, влегувањето во инвестиција без снимање на претходната состојба и санација на зградата често води кон нерационална и неефикасна потрошувачка. 
5.3 Утврдување на загубите на топлина низ обвивката на фасада со помош на инфрацрвена термографија.

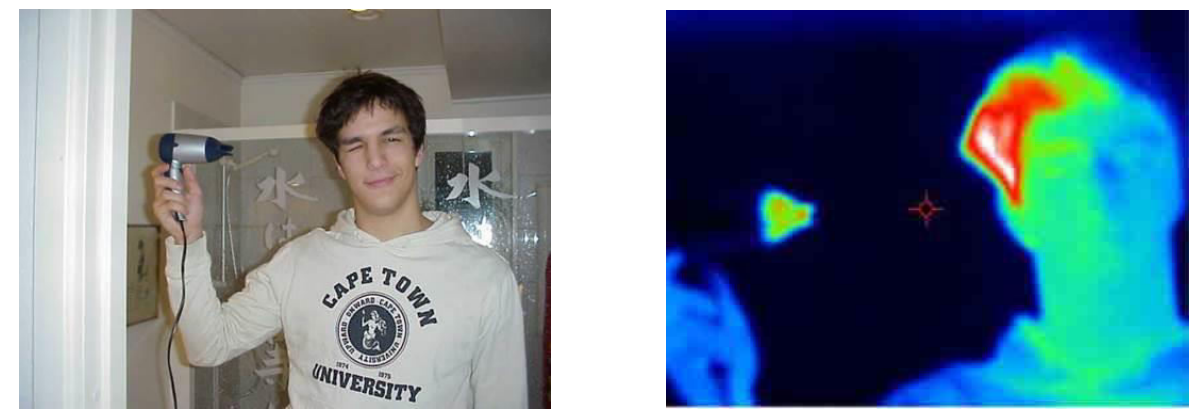

Фигура 21: Мерење на површинска температура кај мерен објект Извор:Логинг електроникс (2013:7)
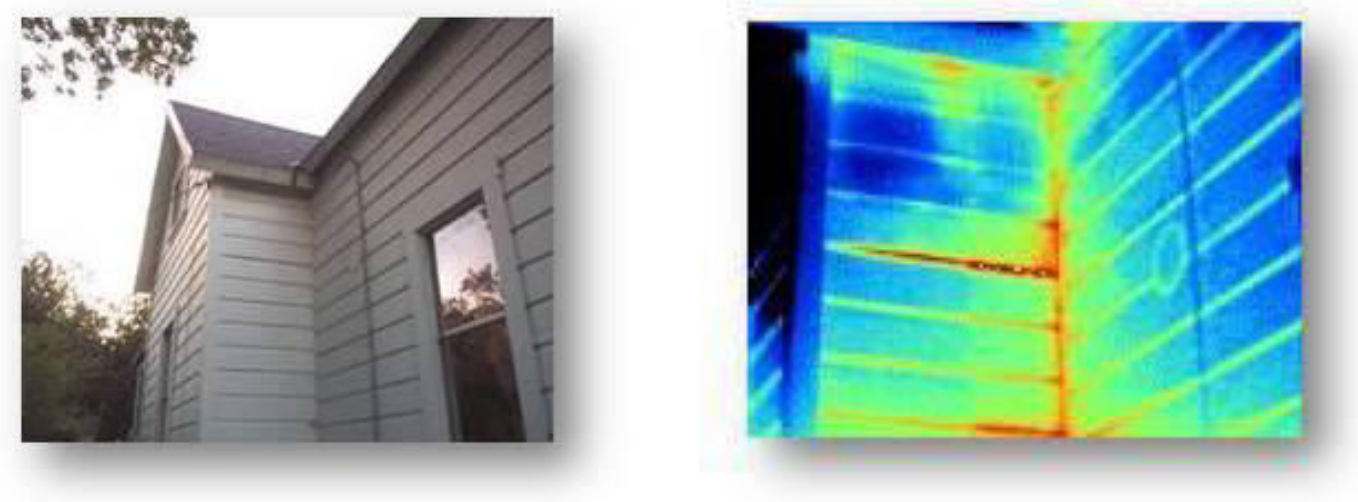

Фигура 22: Придобивки од термовизијата Извор: Логинг Електроникс (2013:8)

Логинг Електроникс (2013) во презентација за својата дејност потенцира дека "Термовизијата е наука за визуелизација на емитираната топлина во облик на разбирлива интуитивна фотографрија." Овој термин Термовизија може да се каже дека е одомаќен, со оглед на тоа што се работи за видео запис. Всушност Штрбац (2011) ја дефинира термовизијата како метода која овозможува мерење на инфрацрвени - топлотни зраци од површината на сите тела со температура над апсолутна нула. Се работи за дигитална инфрацрвена термографија која овозможува мерење на температурата на сите тела, машини и надворешни зидови, за многу кратко време. Со систематско снимање на станбените објекти може да се провери градбата дали е солидна од енергетски аспект. Многу лесно и брзо се детектираат слабите места во изолацијата или 
влагата кај делови од старите згради, како и критичните места на обвивката на зграда. Миловановиќ (Milovanovič н.п.) за инфрацрвената термографија ќе потенцира дека сигурни резултати ќе даде како квалитативна метода кај контролата на квалитетот на новоградбите. Тој образложува дека квантитативното мерење на коефициентот на премин на топлина $U$ e невозможно со термокамера од причина што условите за премин на топлина се нестационарни, туку во одредени случаи еднодимензионални. Ако од постоечката документација и прегледот на самата локација не може да се одреди составот на обвивката, се земаат коефициенти за премин на топлина според претпоставени заклучоци од периодот на градба. Со термографијата се мери само површинската температура на мерниот објект, но и тука постојат негативни импликации кои можат да ја намалат реалната температура каде една од причините е појава на ветер. Други негативни импликации или ограничувања врзани со оваа метода се климатските услови. Мерењата мора да се вршат во зимски услови без појава на ветер и осончување како би се добила реалната состојба на премин на енергија за греење од внатре кон надвор. Препорачано е температурната разлика помеѓу внатрешниот и надворешниот воздух да е 10К (Келвина). При енергетски преглед кај постоечки објект термовизиската камера може многу да помогне како еден вид енергетска ревизија. За брзо и јасно детектирање на влага и голем премин на енергија кај обвивката на фрасада, со термовизија се третираат системите за греење, ладење и уредите со кој се напојуваат. Согласно добиените сознанија од мерењата се превземаат и соодветни акции. По санација и модернизација на зградата, со повторно мерење се верифицира успешноста на превземените мерки.

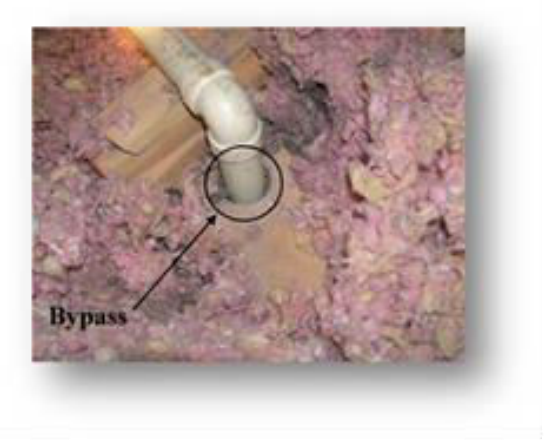

Фигура 23: Воздушни струења

Извор: Логинг Електроникс (2013:23) 


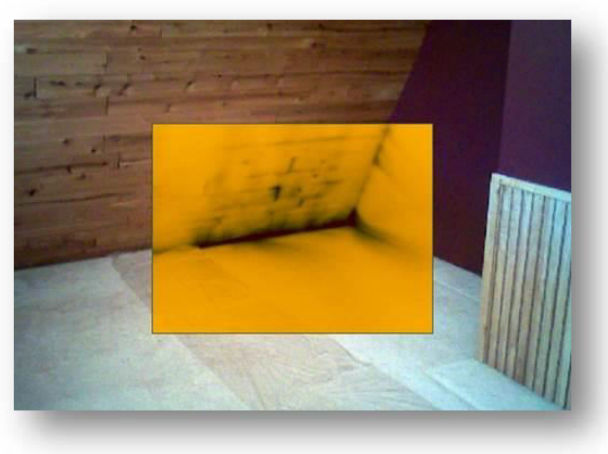

Фигура 24: Локализирање на местото на струење Извор: Логинг Електроникс (2013:29)
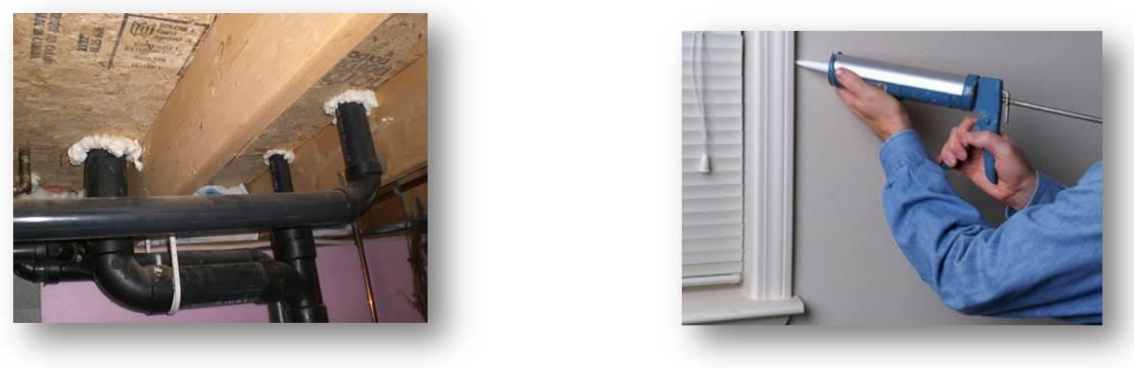

Фигура 25: Воздушни струења - поправки Извор: Логинг Електроникс (2013:32)

5.4 Мерење на вентилационите загуби или методата за мерење на воздушни струења во објектите

"Воздушните струења кај обвивката на зарада може да се дефринираат како отпор при премин на воздух од внатрешноста на зградата или влез од надворешен ладен воздух, во внатрешноста на зарадата преку пукнатини, шуплини и други места кои настанале со ненамерни пропусти, а никако преку cocmaвот на изолацијата" - Миловановиќ (Milovanovič н.п.:41). Овој процес уште се нарекува и инфрилтрација заради разликата во воздушен притисок на двете страни, надворешноста на обвивката и разликата на воздушен притисок во внатрешноста на објектот. Методата се користи за мерење на воздушните сруења со создавање на присилна разлика на притисоците помеѓу внатрешноста на објектот и надворешниот воздух. Најчести причини кај еден објект кој има инфилтрација на воздух се бараат кај прозорци кои не заптиваат, завршетоци на електрични инсталации, пенетрација од тавани, споеви со 
инсталации во зидови, дефекти во конструкција. Со компресионата метода, дознаваме колку е лоша изолацијата од воздушните струења, додека термовизијата е проверка и осознавање каде е лоша изолацијата, предизвикана од воздушни струења. Со санација на местата со употреба на силикон, пена, изолациски плочи се поправаат пукнатините или предизвикувачите на инфилтрација на ладен воздух. Поправените места пак може да се валидализираат со термовизиски запис.

Фигура 26: Тестирање на воздушна непропусност со компресиона метода (Blower Door Test) Извор: Логинг Електроникс (2013:30)

5.5 Едукација и соработка со корисниците - сопствениците на становите

"Енергетското снабдување и потрошувачка се социотехнолошки по природа: технологија и однесување интерактивно и соединети заедно временски." Дарби (Darby 2006:5). Модернизацијата на постоечките згради станува неопходна појава во денешно време и често на корисниците им изгледа дека тоа е само едноставно реновирање на фасадата на објектот. Но реалната модернизацијата со енергетски концепт е сложен процес кој, ако не се одвива системски може да покаже доста негативни резултати. Овој процес може да биде успешен ако се совладат неколку околности кои воопшто не се едноставни. Тоа подразбира долги расправии со сопствениците, континуирана и висококвалитетна едукација, дефинирање на предностите и демонстрирање на добра пракса. Најчесто главен проблем на корисниците - сопствениците е наоѓање на фринансиски сретства за вложување во модернизацијата. Доколку 
на истите им се овозможи информацијата и поттикне иницијатива за заштеда во иднина, би можеле да отпочнат со земање на кредити или субвенции за енергетска ефикасна обнова. Изборот на високо едуцирани компании, инженери, архитекти кои можат да спроведат енергетско ефикасна модернизација е есенцијален почеток на решавањето на проблемот. Истите треба да овозможат едукација, информираност и учество во процесот, на сопствениците на становите. Според Хазука (Нazucha 2010) во некои европски земји постои модернизација од страна на сопствениците на заедници или куќните совети, преку дополнителна изолација на фасади, менување на прозори, но овој процес не е континуирано плански претставен така да можни се грешки и недоволно квалитетен резултат. Во секој случај детектирање на проблемите и потребите на корисниците - сопствениците на станови и нивното решавање со уважување на нивните предлози е единствен начин кој води до вистинско ефикасна модернизација и задоволно население. Бидејќи проблемот е комплексен не доволната информираност на корисниците - станарите и во европските земји довела до протести и правни мерки против реновирање. Поради тоа направен е план со приложување на информации, брошури и сл. како би се појаснила добрата намера на самите сопственици на станови. Како една од позитивните комуникациски методи се: јавни состаноци, прашалници, интервјуа, анкети, преглед на договорите, нови случувања и сл.

Најдобро е да се најде решение за изведба на работите без раселување на станарите, а тие пак да бидат запознаени со референците на компанијата изведувач, можноста за анализирање на цените на пазарот, да им се овозможи договор според кој ќе се изведува со надзор од правно лице, квалитет, гаранција и пенали ако има пропуст во изведбата. Кога овие работи една по една систематски ќе се сложат, бенефитот од повратните средства и придобивките на енергетско ефикасна модернизација би биле успешни. Но како што напоменува Морвај и др. (Morvaj et al. 2010), енергетската ефикасност не застанува со овие превземени мерки таа е континуиран процес кој се развива и пренасочува, каде самите корисници ќе ја продолжат и негуваат. Ова се нарекува и фаза на користење на реновирана зграда според енергетски концепт. Тешко се менуваат долгогодишните навики, но без правилно однесување тешко ќе се намалат и трошоците. Според Дарби (Darby 2006:4) "Луѓето можеби имаат додатна потреба од помош во промена на 
навиките...". Денес кога оваа тема е многу актуелна не може да не се напомене дека институциите се трудат, начинот за штедење на енергија да го изменат со воведување на едукативни програми кај најмладите генерации. Проактива (Proaktiva 2007) има издадено прирачник за енергетска ефикасност каде младите ученици ќе бидат запознаени со начинот на енергетско ефикасно однесување. Хазука (Hazucha 2010) кај веќе реновирани стари згради, воочува дека е потребно екстерна организација да издаде брошура за корисниците после процесот на реновирање. Треба да се обрне внимание на континуирана заштеда која единствено ќе опстои доколку постои контрола и развој на индивидуалните нови навики поткрепени со енергетско ефикасна култура. Дарби (Darby 2006). Утврдено е дека главните проблеми во однесувањето на станарите е тешко менување на навиките во однесувањето кон енергетско ефикасни реконструкции. Содагар (Sodagar 2013) укажува дека зградите се носители на културата и социјалната состојба во едно општество.

5.6 Смерници за модернизација на зградите со енергетско ефикасни мерки

За успешна имплементација на енергетско ефикасни мерки во реконструкцијата на постоечки згради пред сё треба да се организираат одредени барања.

- Законска регулатива во корелација со европската на полето на заштеда на енергија, топлотна заштита и примена на обновливи извори на енергија.

- Зголемување на термичката изолација.

- Ефикасно греење, ладење, вентилација, осветлување.

- Енергетска конрола, управување со потрошувачката.

- Нормативи за максимална потрошувачка на енергија.

- Воведување на енергетски сертификат.

- Едукација и промоција на мерките и бенефитите од енергетската ефикасност.

Со примена на мерките за енергетска ефикасност треба да тежнееме кон задоволување на :

- Пријатна температура во зима и лето.

- Нормална релативна влажност на воздухот.

- Мерки против кондензација на внатрешни површини и појава на мувла 
- Заштита од инсолација во лето ( да се користат елементи на фрасада за заштита од сонце.)

- Продор на сончеви зраци во зима, во зависност од азимутот.

- Добро затнување на сите фрасадни отвори против провев.

- Обезбедување на задоволителна изолација против бучава.

5.7 План за проектирање - реконструкција со примена на енергетски концепт

При реконструкција на постоечки станбени згради со превземање на енергетско ефикасни мерки, потребно е да се вклучат стручни и овластени кадри. Потребно е да се направи проект за реконструкција кој претходно ќе биде јасно дефиниран во колкава мерка ќе се модернизира. Но пред секој проект мора да се изврши секако увид на состојбата на објектот од градежен аспект и проценка на енергетската потрошувачка. Врз основа на постоечката (фактичката) состојба се проектираат нови мерки на заштита, нови детали со претходно анализирани и одобрени материјали за изолација, тип на прозори, завршна обвивка и т.н. Покрај овие основни мерки од голем придонес за енергетско ефикасна градба би било и можното искористување на соларните добивки во зима и засенувањата на јужната ориентација во лето. При тоа, ако се искористи и можноста за произвотство на соларна енергија секако ќе се пружи висок стандард кој би бил видлив во енергетскиот сертификат. Под енергетско ефикасна градба се подразбира онаа која ќе овозможи намалување на топлинските загуби низ надворешните површини, зголемување на топлината во просториите, како и добра механичка вентилација. Лехнер (Lechner 2013) сака да укаже дека сите превземени енергетско ефикасни мерки треба да се подредат по скалило и прво да се употребат подостапните начини и методи за решавање на проблемот, отколку високо технолошки превземени мерки. Неговото мото е принципот на " берење на плодовите кои се прво на дофрат на рака.". Почнувајќи од искористување на обновливи извори како сончевото загревање, внесување на сончеви зраци и заштита од прекумерното сонце. Според Лехнер (Lechner 2013) последни би биле високософистицирани и скапи мерки како на пример соларни панели и фотоволтаични системи. На пример:

- Прво потребно е да се разгледа ориентацијата кај објектите ( ова важи за новопроектирани), Доколку ориентацијата на објектите по должина би 
била ориентирана прма југ, според Лехнер (Lechner 2013), заштедите на енергија за греење, ладење и осветлување би биле до $50 \%$.

- Бојата на објектот. Ова подразбира дека светлите бои се потребни, поготово за јужната ориентација бидејќи не ги впиваат сончевите зраци во летниот период како темните фрасади и не доведуваат до прегрејување на зидовите.

- Месоположба и големина на прозорите. Оваа позиција исто важи за новопроектирани објекти.

- Пасивно осончување, или внесување на светилна во зимските денови.

- Полици за засенување

- Соларни панели

- Фотоволтаични панели

Градежните елементи врз кои се превземаат посебни мерки, според Башиќ и др. (Bašiš et al. 2008) ce:

- Топлинска изолација на надворешните sидови

- Избор и правилно вградување на надворешни прозорци и врати

- Соодветна заштита на топлинските мостови

- Посебен третман на деталите каде е спојот со балкон и меѓукатната конструкција

- Топлинска изолација на кров

- Топлинска изолација на подови над негреани простори - подруми и сл.

- Можност за вградување на елементи за соларни добивки и заштита

- Предвидување на механичка присилна вентилација

Верификацијата на еден ваков тип на градба би се реализирала секако со софистицирана термовизија.

5.7.1 Надворешен sид - правилен избор на термоизолацијата

Една од основните потребни мерки за заштита на пренесувањето на топлина е изборот на топлотна изолација кај обвивката на фасада. Се разбира, поголемиот дел од таа обвивка ја зафаќаат надворешните зидови. Топлината се пренесува од средина со повисока кон средина со пониска температура. Целта на топлинската изолација е да овозможи намалување на загубите на 
топлина при премин на истата кога има разлика на температури во различни средини. Топлинските изолатори кои имаат помала топлинска спроводливост се поквалитетни бидејќи низ нив се пропушта помало количевство на енергија за греење. Николовски (2011:4) - "Во групата на топлинско изолациони материјали се вбројуваат оние чија вредност на коефициентот $\Lambda \leq 0,065 W / m K "$. Но појаснува, дека останатите материјали со повисока вредност на $\lambda^{*}$ имаат свој придонес кон изолациската моќ на градежните конструкции чиј составен дел се истите. Според COSMO (2005:35) - "Bo зависност од големината на коефициентот на топлинска спроводливост $\lambda$, изолациските материјали се делат на ефрективни (каде $\lambda \leq 0,18 \mathrm{~W} / \mathrm{M} \cdot \mathrm{K}$ ) $u$ неефективни (каде $\lambda \geq 0,18$ W/M $\cdot K$ )". Добрите топлинско изолациони материјали, со мала вредност $\lambda$ имаат многу мала маса.

Интересен е фактот дека воздухот кога е заробен во конструкцијата или во материјал има доста голема изолациона моќ. За воздухот може да се каже дека е лош спроводник на топлина, а уште полош од воздухот е вакумот бидејќи нема молекули, па топлината не вибрира. Од тука, како еден од добрите термоизолациони материјали е и самиот воздух. Кога помеѓу два градежни материјала треба да се пресмета дебелината на слојот на воздух, институционално е добиено дека за д=2,5-3см слој од воздух, отпорот $R$ изнесува 0,18 истакнува Николовски (2005). Тоа значи дека оваа димензија на слој од воздух е сосема доволна т.е. колку и да се зголемува дебелината на слојот од воздух, отпорот ќе биде $R=0,18$. По овие податоци, се поставува прашањето кој изолационен материјал е најдобар? Одговорот, при многу анализи и експертизи е дека најдобар термоизолационен материјал не постои. Всушност за секој конкретен случај во зависност од конструкцијата во која треба да се вгради и бараните услови, би требало да се одбере најповолен термоизолациски материјал. При изборот на изолацијата секако треба да се имаат во предвид некои фризички својства на пр: структурата, фрормата, механичката отпорност, стисливост, еластичност, способност за впивање вода, отпорност на дифузија на влага, отпорност од пожар, хемискиот состав, димензионална стабилност, еко фактор, економичност, лесна монтажа. Според COSMO (2005) изолационите материјали, во зависност од составот, се делат на органски и неоргански. Во неоргански термо изолациони материјали спаѓаат: минерална и стаклена волна, гас-бетон, пенест бетон, песок од експандиран 
перлит, керамзитов песок, чакал и др. Органски материјали се: хераклитни плочи, плутени производи, производи врз база на дрво, трска, пресувана слама, волна и коноп и сл.

Низ изминатите години, во пракса најчесто се користи: Минерална и стаклена волна, Стаклена пена, Плута, Експандиран полистирен (EPS) режан во блок, Експандиран полистирен (EPS) изведен во калап, Екструдиран полистирен (XPS), Фенолни плочи, Полиуретански плочи, Поливинилхлорид (PVC) плочи, Камена волна и др. Мислењата за еден производ секогаш се контрадикторни, во зависност од комерцијалната конкуренција. Но, излагачите на термо материјали на Неделата на енергетска ефикасност (2013) објаснуваат дека материјалот треба да содржи сертификат со "Европско Техничко Одобрување" (European Technical Approval - ETA). Сертификатот обезбедува: противпожарност, механичка стабилност, хигиена, здравје и еко издржливост, звучна заштита, безбедност при користење и енергетска ефикасност. Како посовремени материјали се и Вакумирани Изолациски Панели (VIP), кој во својот состав содржат прав ( SiO2 агломерат) приложува Николовски (2011). Според Лувоџ (Luwoge н.п.) во Европа се актуелни зидови што содржат "материјали за размена на температурата на воздухот " (Phase Change Materials - PCM) кој имаат својство латентно да ја акумулираат топлината и полека да ја оддаваат кон просторијата. Во себе содржат микроскопски пластични восочни палети кои имаат можност да складираат топлина. Принципот на работа на овие восочни топчиња е да апсорбираат висок степен на топлина во лето каде истата многу полека се испушта. Овие латентни акомулатори можат да заштедат енергија, препорачуваат Лувоџ (Luwoge н.п.).

$\lambda^{*}$ - коефициент на топлотна проводливост, претставува количество на топлина која за време на 1 сек. минува низ материјал со дебелина 1 м и површина од $1 \mathrm{M}^{2}$, при температурна разлика од $1 \mathrm{~K}$ меѓу две страни на материјалот. 
5.7.2 Правилна поставеност на термоизолацијата кај надворешен зид

Од аспект на поставеност на изолацијата кај надворешните зидови се практикуваат три типа на поставеност и тоа: од внатре, во средина (сенвич систем), и од надвор. За правилна поставеност на изолацијата од голема важност се видот и значењето на објектот. Правени се експертски анализи со пресметка на температурата во слоевите на зидовите. Вршени се анализи на дејството на кондензацијата врз зидовите. Од фигурите 27 и 28, и таблиците може да се види дека не е важен само изборот на материјал со ниска $\lambda$ вредност, туку и на кое место е поставен самиот материјал како и неговата волуменска вредност. Цветковска во денови на енергетска ефикасност (2012) потенцираше дека ..."2,5 пати повеќе време му треба на објектот да се олади доколку се постави изолациониот материјал од надворешна страна на конструкцијата." (...) Башиќ и др. (Bašič et al. 2008) за поставеноста на изолацијата од надворешната страна на фасадата дефинира два типа на поставување. Првиот е со лепење на термоизолациски слој кој се нарекува компактна фасада. Вториот тип е вентилирана фасада, што значи дека измеѓу термоизолацијата и облогата на потконструкција струи воздух. Според него, препораката на термоизолацискиот слој не би требало да биде помала од 10$12 \mathrm{~cm}$, за да може коефициентот на премин на топлина да изнесува $U=0,25$ $0,35 \mathrm{~W} / \mathrm{m}^{2} \cdot \mathrm{K}$.

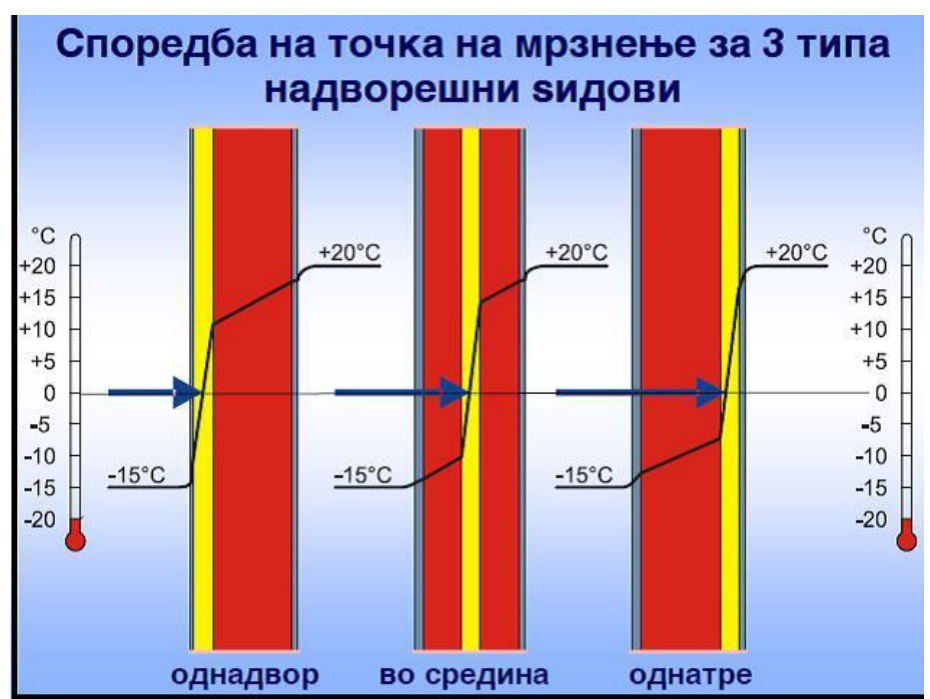

Фигура 27: Поставеност и местоположба на изолација

Извор: Николовски (2011:4) 


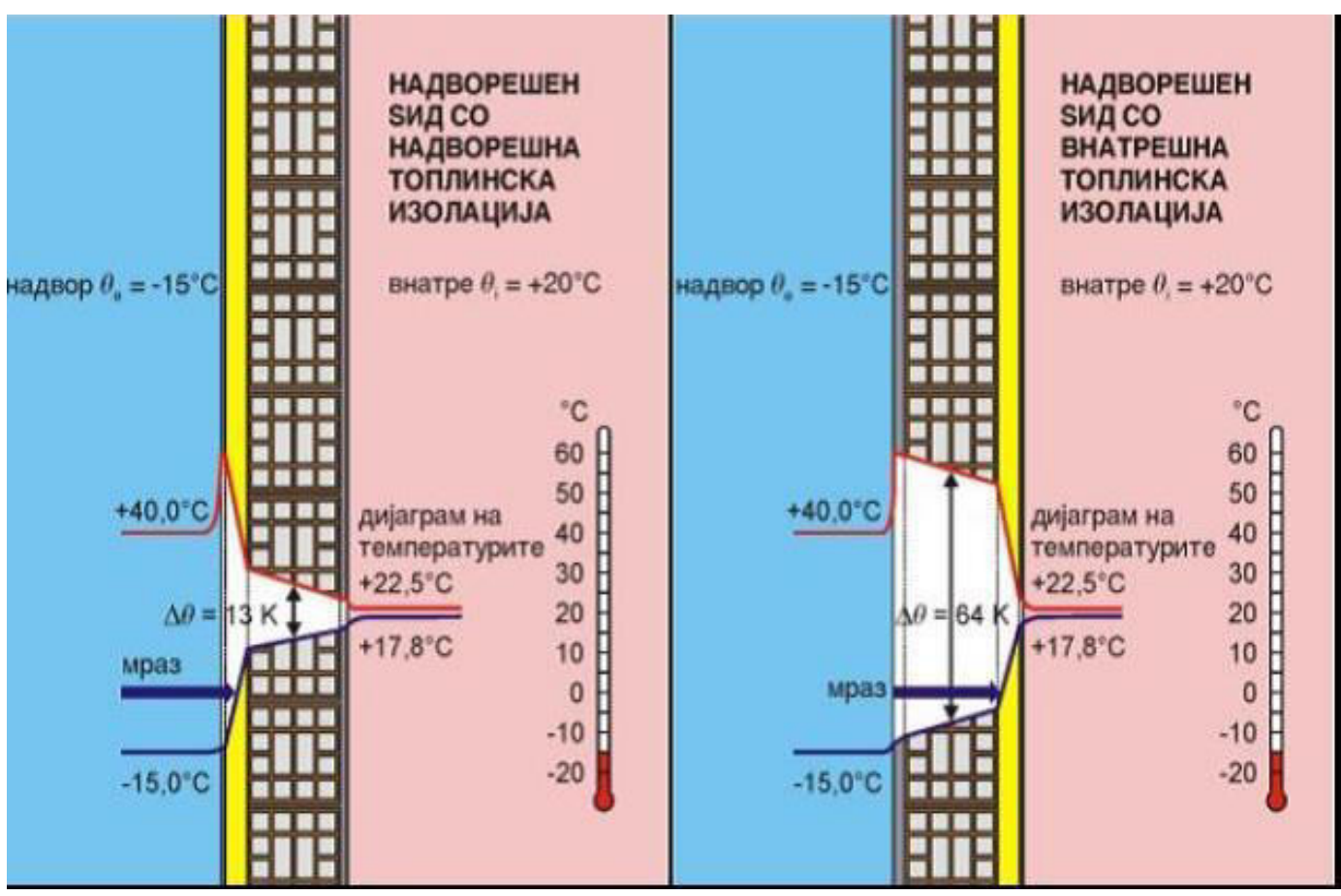

Фигура 28: ид со надворешна и внатрешна изолација Извор: Николовски (2011:4)

При компарација на материјалот за термоизолација од аспект на неговата поставеност донесени се следните заклучоци:

Табела 1: Компарација на карактеристиките на материјалот за термоизолација од аспект на неговата поставеност

\begin{tabular}{|c|c|}
\hline $\begin{array}{l}\text { Sид со надворешно поставена } \\
\text { изолација }\end{array}$ & $\begin{array}{l}\text { Sид со внатрешно поставена } \\
\text { изолација }\end{array}$ \\
\hline $\begin{array}{l}\text { Незабележително влијание на } \\
\text { топлинските мостови или т.н. бенигни } \\
\text { топлински мостови }\end{array}$ & $\begin{array}{l}\text { Според MKC EN ISO стандардите се } \\
\text { јавуваат малигни топлински мостови }\end{array}$ \\
\hline $\begin{array}{l}\text { Минималните внатрешни површински } \\
\text { температури се далеку над точката } \\
\text { на оросување што е гаранција дека } \\
\text { нема да се случи кондензација или } \\
\text { појава на мувла }\end{array}$ & $\begin{array}{l}\text { Минималните внатрешни површински } \\
\text { температури се повисоки од точката } \\
\text { на оросување што претставува } \\
\text { предуслов за појава и растеж на мувла }\end{array}$ \\
\hline $\begin{array}{l}\text { Минимални специфиични топлински } \\
\text { загуби }\end{array}$ & $\begin{array}{l}\text { Зголемиени топлински загуби за 60- } \\
110 \%\end{array}$ \\
\hline $\begin{array}{l}\text { Sидната маса е во стабилна } \\
\text { температурна зона, со минимални } \\
\text { температурни разлики од } 13 \mathrm{~K}\end{array}$ & $\begin{array}{l}\text { Температурните разлики во sидовите } \\
\text { изнесуваат околу } 64 \mathrm{~K}, \text { од тука } \\
\text { произлегуваат големи дилатирања }\end{array}$ \\
\hline
\end{tabular}




\begin{tabular}{|c|c|}
\hline $\begin{array}{l}\text { Точка со температура } 0^{\circ} \mathrm{C} \text { се наоѓa во } \\
\text { изолацијата и целиот sид се наоѓa во } \\
\text { зона на позитивни температури }\end{array}$ & $\begin{array}{l}\text { Точка со температура од } 0^{\circ} \mathrm{C} \text { е во } \\
\text { изолацијата но, блиску до } \\
\text { внатрешните слоеви, така што целиот } \\
\text { sид е во зона на негативни } \\
\text { температури }\end{array}$ \\
\hline $\begin{array}{l}\text { Дифузијата на водена пареа е } \\
\text { стационирана т.е. не постои можност } \\
\text { за кондензирање внатре во слоевите }\end{array}$ & $\begin{array}{l}\text { При дифузија на водена пареа во } \\
\text { зима, постои кондензација во } \\
\text { слоевите, превентивно мора да се } \\
\text { предвиди парна брана }\end{array}$ \\
\hline $\begin{array}{l}\text { Во зима sидот ја акумулира } \\
\text { внатрешната топлина, изолацијата не } \\
\text { дозволува топлината да се оддава кон } \\
\text { надвор, по прекин на греењето } \\
\text { топлината повеќе се задржува и при } \\
\text { повторно вклучување на греење брзо и } \\
\text { со мало количевство на енергија се } \\
\text { постигнува задоволителна } \\
\text { температура }\end{array}$ & $\begin{array}{l}\text { Во зима, внатрешната топлинска } \\
\text { изолација не дозволува зидот да ја } \\
\text { акумулира внатрешната топлина и } \\
\text { постојано е студен. По прекин на } \\
\text { греењето многу брзо се лади } \\
\text { просторот }\end{array}$ \\
\hline $\begin{array}{l}\text { Во лето, изолацијата не дозволува } \\
\text { прекумерно прегрејување на sидот, со } \\
\text { што е овозможена пријатна } \\
\text { микроклима }\end{array}$ & $\begin{array}{l}\text { Во лето, зидот од надвор интензивно } \\
\text { се прегрева и по неколку часа ја одава } \\
\text { кон просториите }\end{array}$ \\
\hline $\begin{array}{l}\text { Дебелината на sидот може да биде } \\
\text { само } 20 \text { см, намалени трошоци за } \\
\text { sидарија и добиена нето површина по } \\
\text { обем на зидот до } 10 \text { см }\end{array}$ & $\begin{array}{l}\text { Кај случајот со изолација во средина, } \\
\text { вообичаената дебелина на sид е } 30 \mathrm{cm,} \\
\text { (со се изолација) со што се одзима } \\
\text { 10см од површината по обем, а масата } \\
\text { ( 2*12см) и цената на sидаријата е } \\
\text { зголемена за } 20 \%\end{array}$ \\
\hline $\begin{array}{l}\text { Исклучени се градежни штети } \\
\text { ( пукнатини) на фрасадата, а } \\
\text { комплетната зидна конструкција е со } \\
\text { долг век на живот }\end{array}$ & $\begin{array}{l}\text { Редовна појава се пукнатини на } \\
\text { фасадниот малтер }\end{array}$ \\
\hline
\end{tabular}


Според горе наведеното битно е да се истакне дека при вградување на материјал за топлинска изолација кај објекти, поставеноста на истиот би се поделила според видот и намената на објектот.

Sид со внатрешна топлинска изолација би било во ред да се изведе доколку објектот има историска вредност, забрана за промена на автентичноста на фасадата, при што слојот за пародифузија треба да се постави од греаната страна. Николовски и Цветковска во денови на EE (2012) истакнаа дека овој вид на поставеност е оправдано искористен кај објекти од типот на викенд куќи каде ни треба брзо загревање на објектот, а брзото ладење не е битно поради фактот што нема континуиран престој. Сид со топлинска изолација во средина, го покажа искуството кај сендвич зидовите, а резултатот се малигни топлински мостови.

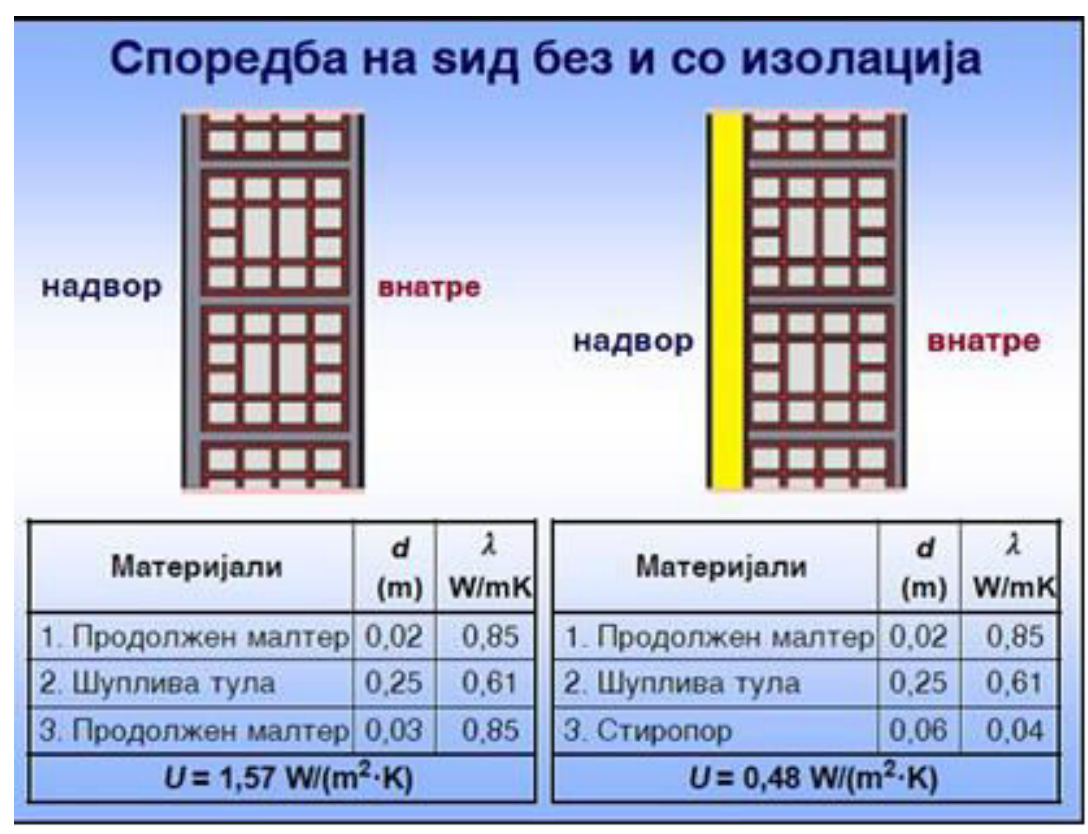

Фигура 29: Споредба на Uвредноста на sид со и без изолација Извор: Николовски (2011:5) 


\subsection{3 Отвори}

Николовски и Констатиновски (2010) во својата публикација го анализираат најранливиот елемент од аспект на термика на една фрасада, а тоа се застаклените површини и нивните термоизолациони својства. Во своите излагања истакнуваат дека за избор на една соодветна стаклена фасада, треба детално да се анализираат енергетските и светлосните фактори на сончевото зрачење и нивното искористување. Вистинскиот избор ќе резултира со посвежи летни и потопли зимски денови. Авторите разработуваат научна анализа, како да се штеди енергија истовремено егзистирајќи со непречен комодитет, а одговорно кон општеството. Битно во овој дел од градежните конструкции е, при реновирање на постоечки објекти, да се применат технологии кои ќе ја искористат сончевата енергија како обновлив енергетски ресурс.

Со монтажа на соодветно стакло и рамки се обезбедува енергетска ефиксност, всушност се овозможува енергетски одржливо планирање на градбите. Познавањето на карактеристиките на стаклото е од суштинско значење за определувањето и оптимизирањето на енергетскиот биланс на зграда. Во вкупниот биланс на топлотни загуби најголеми се загубите низ застаклените површини. Коефициентот на пренесување на топлина "U" е за неколку пати поголем од оној кај sидовите. Затоа треба да се има внимателен приод кон анализата на застаклените елементи во некој објект. Изборот на стакло пакетите и рамките треба да ги задоволи и летните и зимските периоди од годината. Во лето проблемот се решава со соларна контрола, со селективно пропуштање на сончевите зраци во стаклото кои истите се акумулираат во стаклените слоеви и се рефлектираат кон надвор. Во зимските денови изборот треба да задоволи максимален коефициент на премин на топлина, а со можност за внесување на сончеви зраци. Добиената сончева енергија ќе зависи од годишното време, нападниот агол во однос на земјата, географската широчина, временските услови, конфигурацијата на теренот, загаденоста, ориентација на зградите. Башиќ и др. (Bašič et al. 2008) советуваат да се употребуваат прозорски елементи со коефициент на премин на топлина во распон од $U=1,4-1,8 \mathrm{~W} / \mathrm{m}^{2} \cdot \mathrm{K}$. Понатаму, стаклопакети со : двослојно, трослојно, стакло со високи перформанси, исполна помеѓу нив со благороден гас ( аргон, ксенон, криптон, сулфур, хексафлууорид). Со исполната на гас во просторот 
помеѓу стаклата вредноста на коефициентот на пренесување на топлина на стаклото - "Uglass" се намалува за 0,2-0,3Wm²K. Истите се употребуваат кај изолирачки стакла со метализиран слој. Оптимална вредност на растојание помеѓу две стакла е 15мм. За да не се формира кондензација во просторот помеѓу стаклата, средствата од кој е изработен стаклопакетот треба да се квалитетни. Со нанесување на метализиран слој врз површината на стаклото се подобрува изолационата моќ кај стаклопакетите. Тие спаѓаат во стакла со високи перформанси или нискоемисивни стакла. Слојот со ниска емисија има за цел да ја зголеми рефлексијата на топлината апсорбирана од страна на стаклото кон внатрешноста на просториите. За разлика од овие перформанси, обичното стакло лесно ја спроведува топлината кон постудената страна на пример во зима кон надвор, а со тоа се губи големо количевство на енергија. Монтажата на прозорците и вратите на фасада игра многу значајна улога бидејќи, врската со бетонот и ќерамиката со прозорските рамки може да биде причина за поголеми топлински загуби, отколку загубите на топлината на самите прозорци. Овие места се нарекуваат топлински мостови. При реконструкција треба да се тежнее местоположбата на рамката да биде кон надворешната страна на зидот (во однос на фасадата) како би се покрила со стиропор или термоизолационен материјал самата рамка потенцира Башиќ и др. (Bašič et al. 2008). Тоа претставува еден вид заштита за непропусливост или создавање на топлинските мостови. Од друга страна, старите прозорци се предизвикувачи на загуби на енергија, новите како непропусливи можат да предизвикаат голема влажност во просториите. Решението на овој проблем Хазука (Hazucha 2010) го објаснува со механичка вентилација со довод на свеж и отсис на потрошен воздух.

\subsection{4 Балкони, стреи, натстрешници од бетонски елементи}

Овие градежни елементи се вбројуваат во комплицирани детали бидејќи представуваат предизвикувачи на топлински мостови. Поради конструктивни сеизмички причини овие исфрлени бетонски елементи мораат да имаат цврста врска со системот, па одтука Николовски (2012:175) ке истакне дека -" За која било местоположба на фрасадната топлинска изолација, проблемот останува актуелен." Еркерите како осетливи конструктивно - сеизмички 
елементи, се армираат и во горната и во долната зона. Но денеска постојат и готови решенија и детали на ваков тип на градежни елементи кои позитивно одговориле на овој проблем. Всушност се работи за федер - јазол решение кое овозможува одделување на конзолата од носечкиот систем.

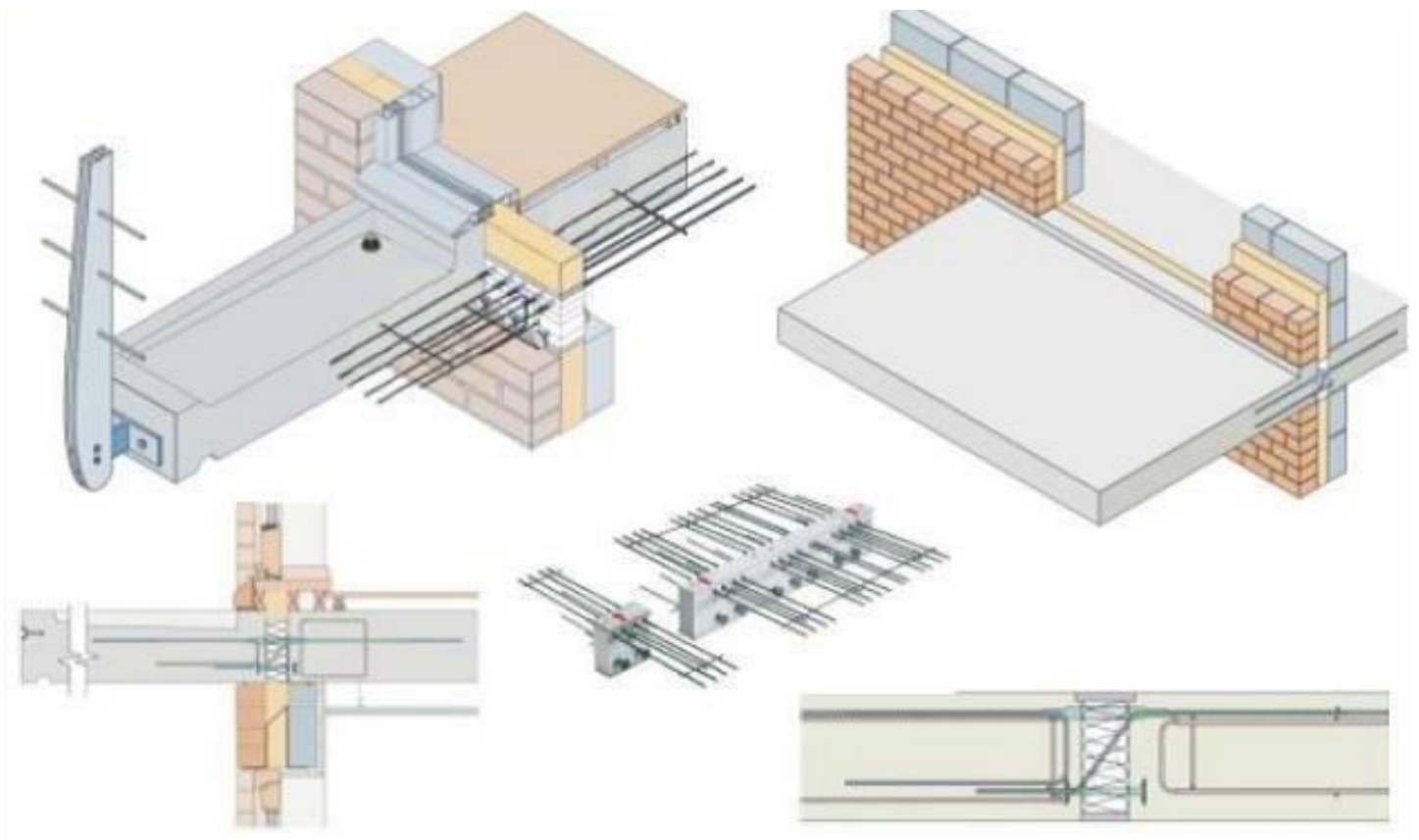

Фигура 30: Дилатирање на балконска конзола, систем - HALFEN -DEHA Извор: Николовски (2011:2)

За жал ова решение не е достапно за примена кај постоечките згради. Отстранувањето на балкони и додавање монтажни, по примерот на Феист (Feist 2010) исто така не одговара за наши услови од причина што зградите погодни за модернизација, меѓудругото се со висина над 20м. Оваа операција на отстранување и поставување може да донесе потешкотија од сеизмички, безбедносни причини, не одговара ни финансиски, а на крај и културолошки. Останува единствено решение со дополнителна изолација на балконската конзола. Заради подобрување на деталот кај балкони од енергетски аспект битно е да се обложи од сите страни вклучувајќи ја и нагазната површина. Овој зафат има секако и добри и лоши страни, а и не е секаде применлив. Затоа овие места се нарекуваат критични и проблематични и е потребно да се бара континуирано решавање на проблемот. Николовски (2012) позитивната страна на ова подобрено решение ја прикажува во фигура 31, со прикажување на значително покачување на внатрешната минимална површинска температура Osjmin од 13,9॰C - 16,3॰C и намалената вредност Че од 0,75-0,31W/ (m $\cdot \mathrm{K})$. Негативната страна на ова подобрено решение е комлицираната изведба со 
тоа што по изолирање на нагазната површина треба да се овозможи зајакнување на истата како би била во функција, што од една страна е додатен трошок и застој во работите. Секако во овој случај ќе се јави проблем поради поставеноста на отворот - надворешна врата во ситуации каде прагот е многу ниско поставен. Произлегува дека ова решение не задоволува во сите ситуации и позиции на фасада, но за да се постигне правилна енергетско ефикасна санација, овој детал на конструкција треба да има континуирано поставена топлинска обвивка. Ваков тип на обложување Башиќ и др. (Bašič et al. 2008) го препорачува и кај стреи, кутии за ролетни, конзолни испусти и на оние места каде има појава на топлински мост.

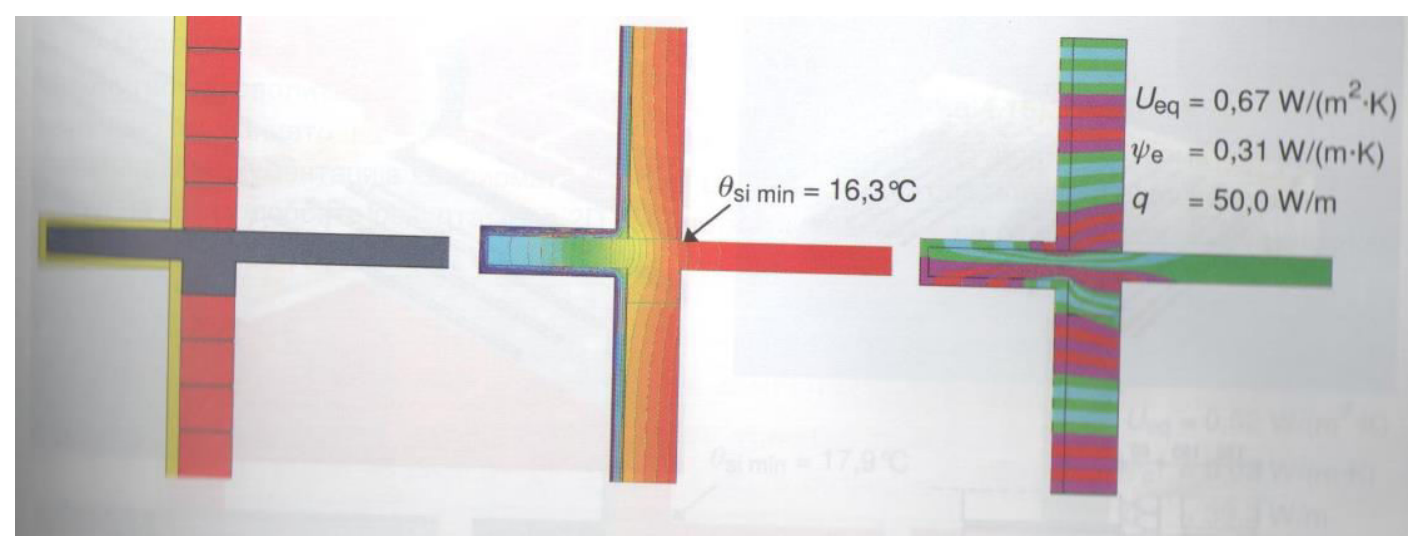

Фигура 31: ЦЦелосно изолиран балкон во зид со надворешна изолација Извор: Николовски (2012:177)

\subsection{5 Останати конструкции}

Ce препорачува да се направи детална топлинска пресметка на останатите делови од конструкцијата, а поготово кај комплицираните детали.

Треба да се посвети посебно внимание на врските меѓу : под - sид, покрив sид, подрумски простории или под на терен. Да се минимизира ризикот од кондензација врз внатрешните површини од зидовите или во самиот состав на кидот. 
Термо изолација на кров

Важна улога во квалитетот на комфророт за живеење зазема покривната конструкција со добро вградена термоизолација. Праксата покажува дека во борбата за станбен простор често пати се случува поткровјето да биде изведено или пренаменето како станбена единица, без разлика дали има соодветна изолација. Во случај кога покривањето не е соодветно изолирано загубите на топлина можат да достигнат и до 30\% укажува Башиќ и др. (Bašič et al. 2008). Во пракса, условите за живеење се отежнати како во лето поради прегрејување на просторот, така и во зима поради брзото ладење. Чести појави на влага и мувла има доколку не е извршена соодветна изведба или реконструкција. За сето ова да се ублажи треба да се превземе реконструкција на покривачот. Реконструкцијата е економски оправдана од една страна, а ќе се овозможи и подобрување на комфорот и намлување на трошоците. Препорачано е да се користат незапаливи изолациони материјали со својство на паропропусност. Башиќ и др. (Bašič et al. 2008) појаснува за деталот покрив - sид. Треба да се обрне внимание во изолирање на покривот кој виси и тоа од долна страна. Со еден збор, деталот да биде решен без појава на топлински мост. Хазука (Наzucha 2010) го појаснува поставувањето на изолацискиот слој, каде се препорачува да е во два слоја со тоа што првиот слој се поставува помеѓу роговите, а вториот под роговите за да бидат избегнати топлинските мостови. Според Кануф (Knauf Insulation н.п.) препорачана дебелина за термоизолација на кровната површина е 16-20см. При поставување на изолацијата се препорачува и слоевито решавање на вентилиран слој. Кога кровниот покривач не е вентилиран, истиот поради разликата во температура и појава на кондензација ќе биде доведен до оштетувања, скапувања на дрвената конструкција, корозија на лимен покривач и појава на мувла. Од друга страна термо изолацијата нема да ја исполнува својата фрункција поради оштетување. Заради овие причини треба да се вентилира покривачот потенцира НедЦинк (NedZink н.п.) и става акцент на две главни мерки: " А. Да се контролира влажноста кон внатрешната страна на слојот од термоизолација." 
" В. Вклучувајќи растојание на надворешната страна на топлинската изолација која ќе овозможи вентилација према надворешниот воздух." НедЦинк (NedZink н.п.:13).

Кога се работи за рамен кров треба да се напомене дека тие се најмногу изложени на атмосферски влијанија па во нашата пракса редовно се оштетени или има протекувања. Искуствата покажаа дека најважно е правилно да се постави, термо и хидро изолација, заштити од кондензација и соодветно реши одводнувањето и дренажата на атмосферските води.

Термо изолација на под

Постојат два типа на конструкции на подови према негреани простори. Едните се према подрум и се лесни за обработка со изолационен материјал,а воедно и монтажата е многу економична бидејќи нема дополнителни работи.

Подовите кој се на тло при модернизација на постоечки објекти е неисплатлива инвестиција бидејќи треба да се реконструира целиот состав на подот.

\subsection{6 Елементи за заштита од сонце}

Во елементи за заштита од сонце спаѓаат стаклата со високи перформанси кои имаат способност да внесат или да одбијат светлина во зависност од потребите, ориентацијата и поставеноста на истите. Покрај ефректот од стаклата, постојат елементи кои се интегрирани во самото стакло како рефлектирачки ролетни, потоа елементи кои се дистанцирани од обвивката на одредено растојание, а со тоа и овозможуваат засенување или заштита од директна сончева светлина. Еден таков пример претставуваат актуелните брисолеи, кои според Грабријан (1986) датираат од македонска архитектура. Обично се поставуваат по потреба од јужната страна на објектите. Потоа разни типови на ролетни, жалузини, дистанцирани елементи од обвивката на зградата како на пример ламели, летви, сенки поставени на секундарна конструкција, зелени тераси и сл. Најефективни заштитни елементи се оние дистанцирани пред обвивката кои не дозволуваат директно здрачење, но треба да се води внимание за статичката стабилност и ветровите така што овие елементи не се препорачуваат за објекти повисоки од 20м. Лехнер (Lechner 
2013) става акцент на елементот кој е наречен рефлектирачка светлосна полица, а служи за заштита од сонце во зависност од поставеноста пред прозорците и во зависност од нивната ориентација и дирекното сончево озрачување. Овој елемент претставува значајна архитектонска стратегија која овозможува енергетска ефикасност и комфорт, со економично и лесно монтирање на фрасада.
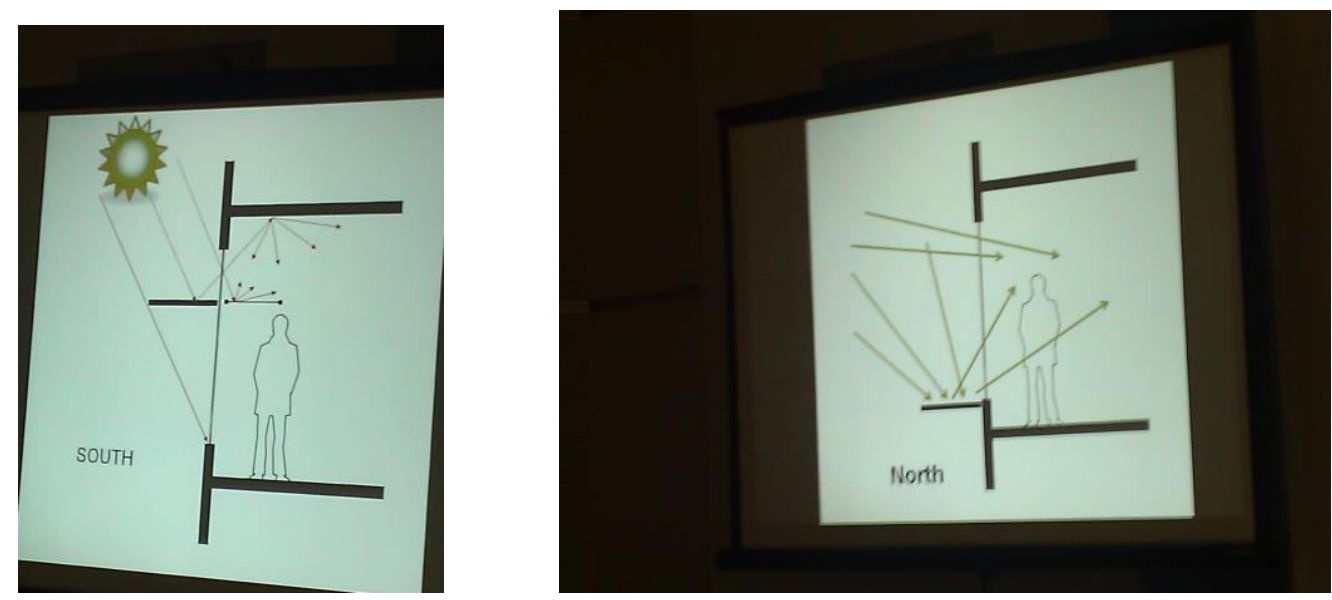

Фигура 32: Рефлектирачки полици за заштита или внесување на сончева светлина и топлина семинар за 2XE предавања, Скопје (2013)

Извор: Лехнер (Lechner 2013)

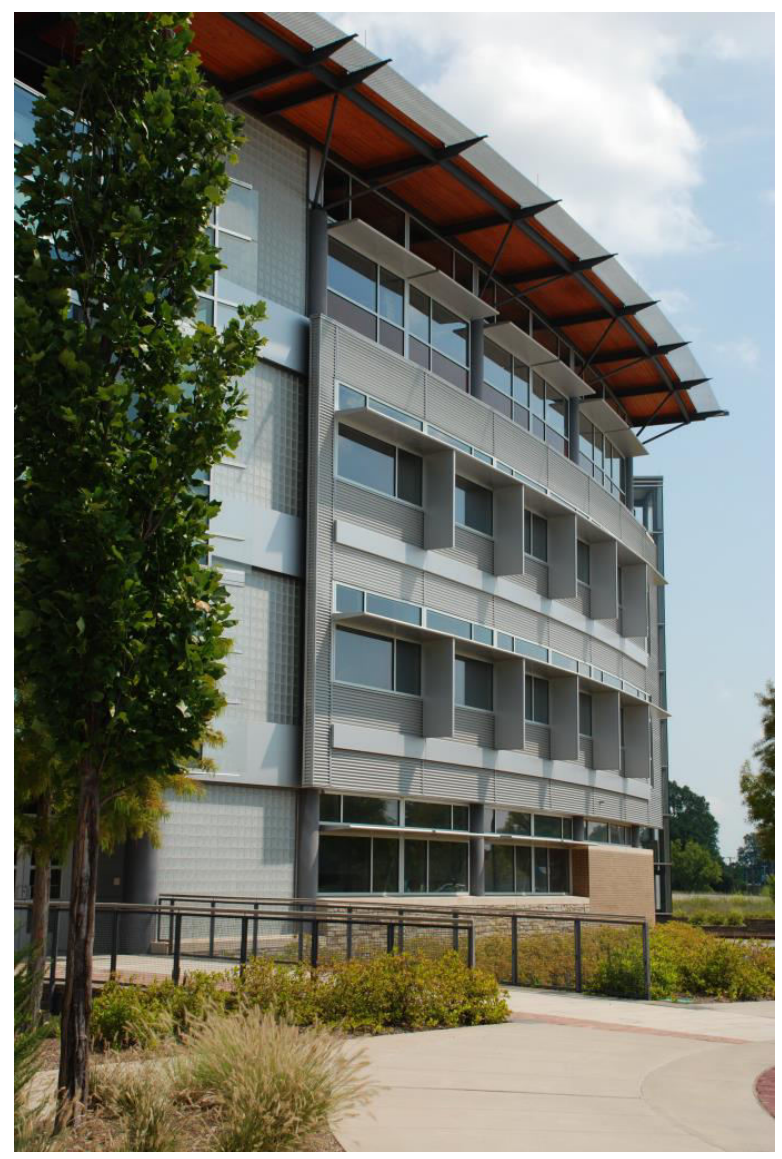

Фигура 33: Светлосна полица - Daylighting light shelf eiffer International USA Извор: Лехнер (Lechner 2013:20) 
5.7.7Грешки при изведбата, препораки и ограничувања
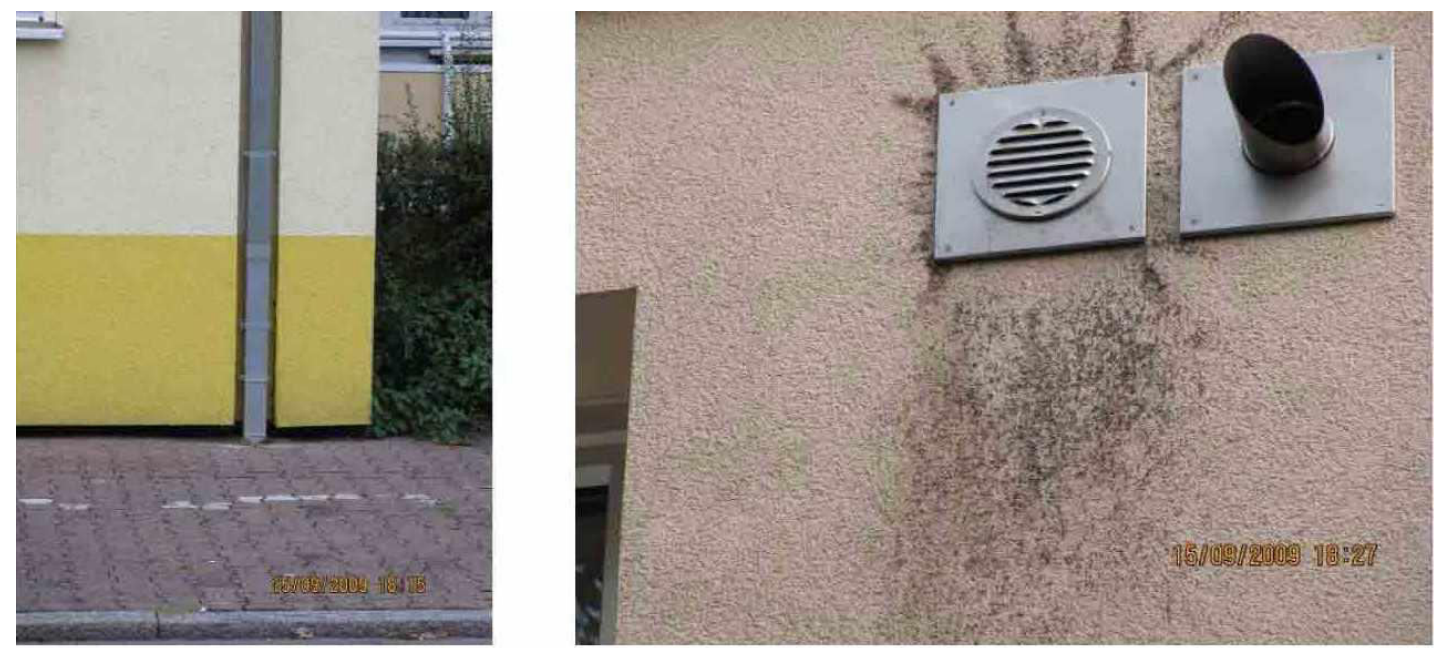

Фигура 34: Грешки при изведба

Извор: Борковиќ (Borkovič н.п:35)

Покрај тенденциите да се овозможи енергетската ефикасност, од фригурите 34 , 35 и примерите се гледа дека и во европските случаи постојат, грешки при изведба. Покрај грешки кај деталите од обвивката на фасада, постојат грешки и во понатамошното однесување на корисниците на становите. Со вградување на механичка вентилација фрирмите изведувачи би требало да вршат мониторинг две - три години, за да ја утврдат потрошувачката и да ги едуцираат станарите за вентилационите загуби преку природното проветрување. Односот на станарите кон модернизираниот објект да продолжи енергетски ефикасно, избегнувајќи самоволни активности во поглед на бушење на делови од фасада заради лични потреби, уништување на нововградената обвивка од изолација и т.н. Од досегашните искуства во пракса и од производителите на материјали за изолација кои имаат свој прописи, може да се заклучи дека секое вградување на изолација која не е изведена во систем од делови, аголници, мрежички и додатни елементи за обвивката на фасада доведува до грешки при изведба, каде со тек навреме ќе предизвикуваат ситни па и позначајни оштетувања, повторна појава на топлински мостови. Целта на овие превземени мерки при модернизација е едно одговорно однесување на сите структури инволвирани во процесот, секако при тоа вклучени се и крајните корисници. 


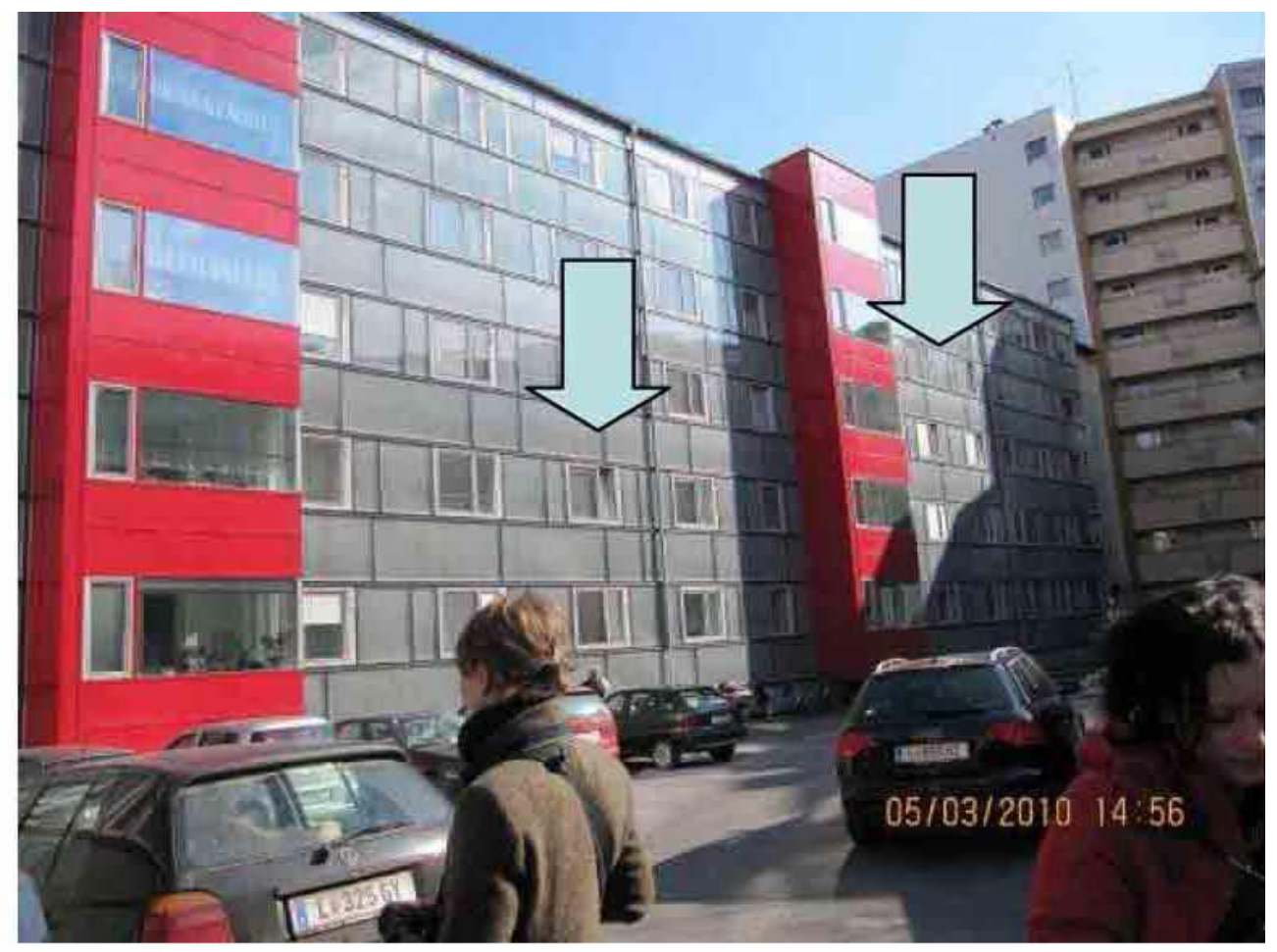

Фигура 35: Неконролирано отварање на прозорци и користење механичка вентилација Извор: Борковиќ (Borkovič н.п:35)

5.7.8 Разгледување на користа - бенефитот од резултатот на модернизација на постоечки објекти

Европскиот институт за преформанси на згради (Buildings Performance Institute Europe - BPIE 2013) детално ги анализира случаите на 29 земји членки на ЕУ од аспект на ограничувања и предизвици во реновирањето на постоечки згради . Според тие анализи создадена е шемата во фригура 36 , каде може да се види кои се̉ пречки делуваат на процесот реконструкција и модернизација на постојни објекти. Се работи за четири точки, кои понатаму се разложуваат во соодветни проблеми. Прво се финансискиот аспект, институциите и административните предизвици, потоа следи способности за софистицирана ефикасност, одвојување на инвестиција и бенефит. Истражувањата за познавањето и ефективноста од повратниот бенефит се актуелни. Дарби (Darby 2006:3) појаснува дека - "Чистиот повратен бенефит е неопходен елемент кој не учи како да се контролира енергенсот, употребува поефикасно за време на долг временски период..." 
Paфp (Rapf) во европскиот институт - BPIE (2013) не убедува дека инвестирањето на нациите во енергетско ефикасно модернизирање на постоечките згради, дава повратен бенефит и придонесува за создавање на нови работни места, квалитет на живеење, економски стимул, енергетска сигурност и контрола на климатските промени.

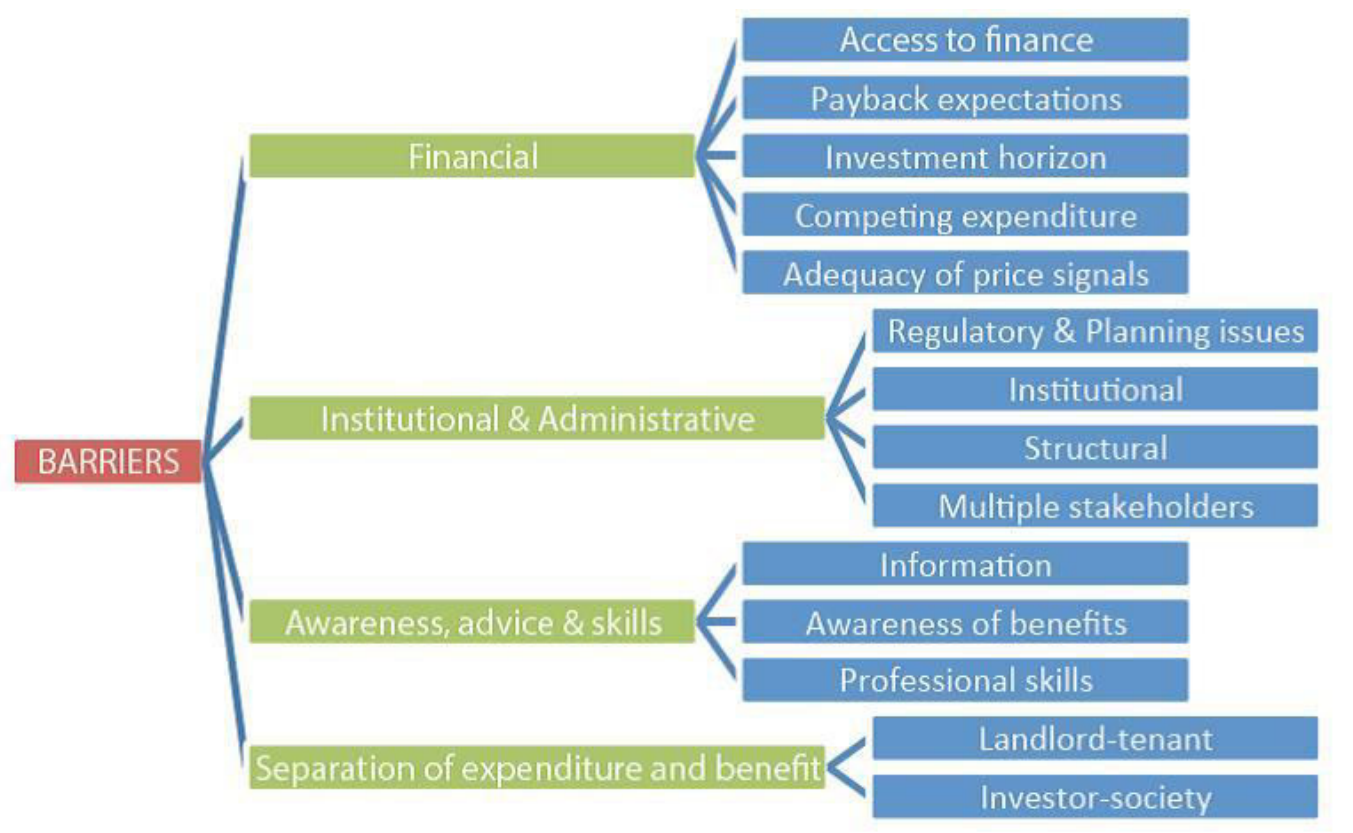

Фигура 36: Бариери при реконструкција Извор : Европски Институт за Перформанси на Згради -BPIE (2013:14)

Затоа, постои потреба од мобилизација на мерките и можностите за создавање на иницијатива кон модернизација на објектите на национално ниво. Директивата за енергетска ефикасност продолжува да се надоградува, во EED, 2012/27/EU вклучувајќи ги препораките кон членките на EУ, со цел да развиваат стратегии за реновирање на постоечките објекти на подолг рок. Разгледани се сите можни бенефити кои произлегуваат од модернизацијата реконструкцијата на постоечките објекти. Истражувачкиот тим на европскиот институт BPIE (2013) спомнува четири оправдани мерки:

- Економскиот бенефит

- Социјалниот бенефит

- Бенефитот кон околината

- Бенефитот кон енергетскиот систем 


\section{Економски бенефит}

Итражувачките анализи покажуваат дека, доколку се инвестира во реновирање на европските постоечки објекти, од сега до 2050 г., заштедите би изнесувале (повратниот бенефит) 1300 милијарди евра. Европскиот институт BPIE (2013:7) потенцира - " Создавање на вработувања би можеле да бидат во просек колку 1,1 милион додатни работни места до периодот на 2050 2". Вработувањата и економскиот развој се стимулирани со инвестирање во одржливи објекти во еден мрежен процес.

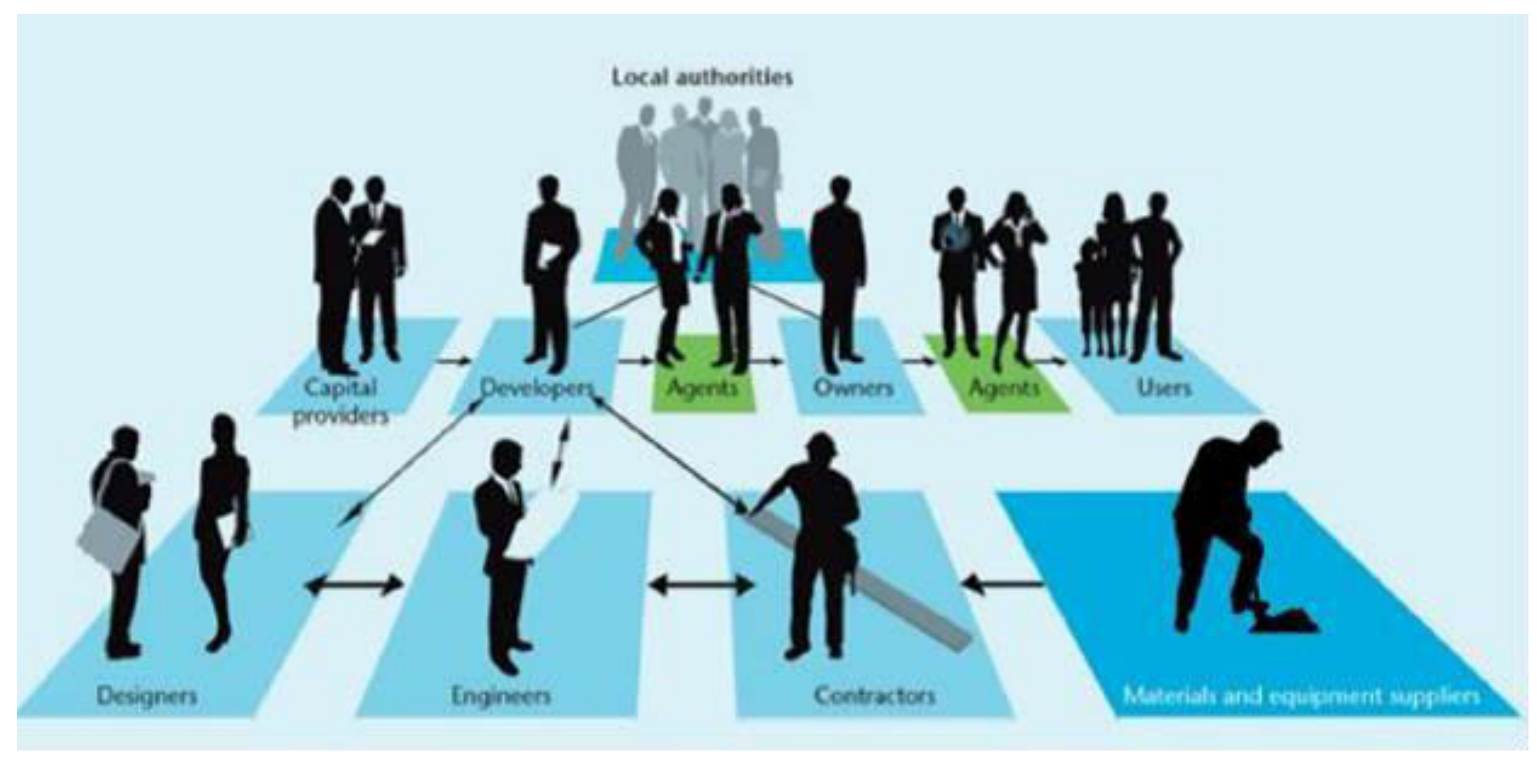

Фигура 37: Шематски приказ на организација на реновирање на зграда Извор : Европски Институт за Перформанси на Згради BPIE (2013:8)

Евидентирано е дека побарувачката и вредноста на објектите кои се градени по енергетско ефикасни принципи, е зголемена во однос на конвенционалните стари системи на градба. Ова е еден ланчан процес во економскиот сектор, каде големите компании за да ја зголемат својата конкурентност на пазарот, а предизвикани од актуелните состојби во градежништвото, развиваат ефикасни материјали и системи. На глобално ниво процесот на реконструкција има позитивно влијание на јавниот буџет. 


\section{Социјален бенефит}

Европскиот институт за перформанси на згради BPIE (2013:7) - "Термичкиот дискомфорт создаден од високи или ниски температури има негативно влијание врз продуктивноста". Во групата на европската популација, 10-25\% страда од недостаток на гориво за греење, истакнуваат од европскиот институт BPIE (2013). Престојот во топли домови генерира здрав живот и развој. Селектирани се неколку случаи и состојби врз човековото здравје кои имаат директно влијание од не енергетско ефикасни објекти или од ладни домови. Заклучокот е дека смртноста предизвикана од прекумерен студ е зголемена кај квартовите со таканаречени ладни станови. Децата кои живеат во ладни домови имаат тенденција да заболат од респираторни болести дури за два пати повеќе од топло вдомените. Болести, карактеристични за живот во ладни бетонски објекти со т.н. термички мостови се ревматизам, артритис и сл. Наведеното не делува продуктивно и врз детскиот раст и развој. "Целокупната енергетска ефрикасност на зградите е идентификувана главно од изолациските карактеристики на обвивката на зграда и механичката вентилација." - Банфи (Banfi 2006:2). Во едно кажано, целта е подобрување на стандардот на живеење, нашиот и на идните генерации како и подобрување во континуитет здравјето на општеството.

\section{Бенефити кон околината}

Ризикот кон загадување на воздухот со прекумерното градење во урбаните средини е огромен. Покрај ова постоечките енергетско неефикасни згради кои емитуваат согорување на СО2 од користење на фосилните горива, претставуваат една алармантна состојба по здравата околина и животот на населението во истата. Денес е зголемен бројот на болни деца и возрасни од белодробни заболувања, каде голем удел има загадувањето од емитувањата на отровните гасови во природната средина.Европскиот институт ВPIE (2013) има анализи каде со едно длабоко реконструкционо сценарио врз постоечките објекти, на национално ниво, може да дојде до намалување на емисиите на јаглерод диоксид, намалување кое до 2050г. би изнесувало 71-90\%. 


\section{Бенефити кон енергетскиот систем}

Повторно да споменам за состојбата со фросилните горива и нивната зависност. Со примена на процесот на термозаштита, обновливи извори, намалување на потрошувачката на енергија, доаѓа до еден вид контрола на енергетскиот систем. Потрошувачката на енергија на национално ниво треба да се редуцира и тоа претставува корист и кон енергетскиот систем кој нема да се оптоварува во прекумерени летни горештини, кога ни е потребно ладење и студени зими каде бараме топлина. Кога свеста на потрошувачот би се подигнала во поимањето на контролите врз енергетскиот систем, бенефитот од тоа би било побогато општество.

\section{6. Европски и македонски примери на модернизирани постоечки згради}

6.1 Проект - СОЛАНОВА - Дунајварош, Унгарија

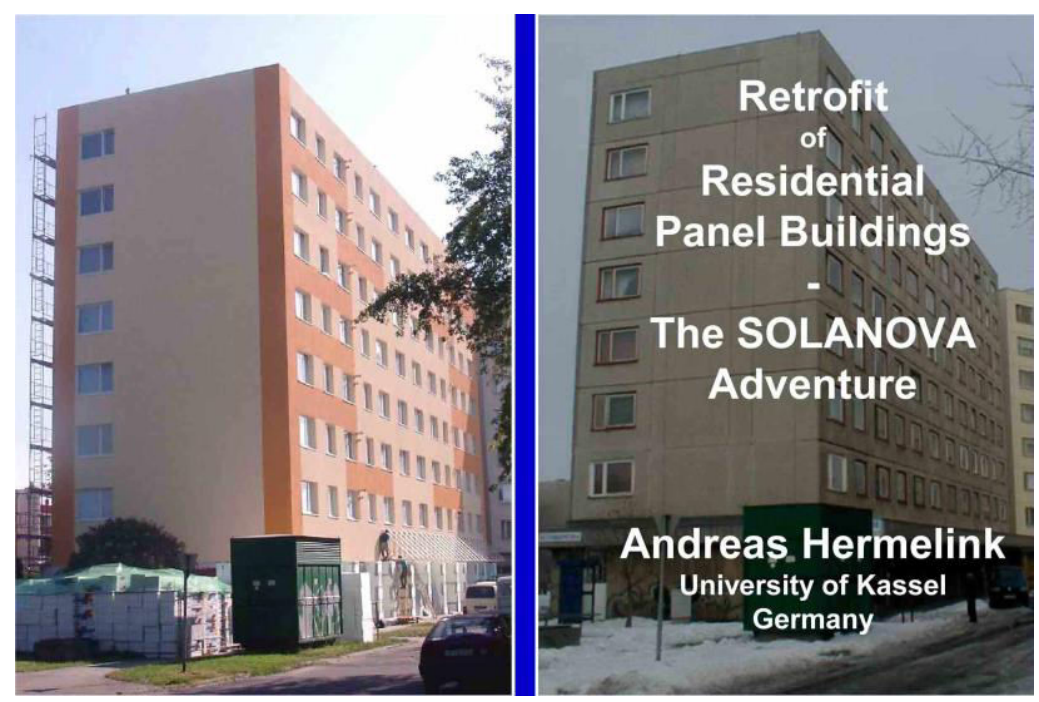

Фигура 38: Проект СОЛАНОВА пред и по реконструкција

Извор: Хермелинк (Hermelink 2005)

Проектот претставува прва реализација на Европската комисија за источна Европа, која се бави со поголеми реконструкции на големи постоечки згради, од програмата "Eco-building". Хермелинк (Hermelink 2005) потенцира дека СОЛАНОВА проектот е "Соларно подржана, интегрирана еколошко - ефикасна реконструкција на голема станбена зграда и топлинска подршка на системот." Хазука (Hazucha 2010:37) кажува дека - "Целта на овој пилот- 
проект е сеопфратна обнова на станбена зграда градена од префрабрицирани елементи со фрактор 10, што значи 10 пати помалку потреба за енергија за греење по реконструкцијата." Истражувачкиот период и почетокот на реконструкција започнува во јануари 2003г. Модернизацијата е во 2005г и овој пример се смета за висококвалитетен енергетско ефикасен објект кој со потрошувачката на енергија за греење во втората година од користење по модернизацијата е блиску до пасивен објект. Претставува пример за станбен објект кој ќе послужи во имплементација на модернизација кај други слични објекти. За успешност на проектот инволвирани се:

- Универзитетот во Касел (Kassel, Center for Environmental Systems, Research -WZ III).

- Универзитетот во Будимпешта (Budapest, Technology and Economic).

- Енергетски Центар Унгарија (Energy Centre Hungary).

- Институт за пасивни куќи (Passive Hause Institute).

Покрај учевството на горенаведените институции и употребата на високотехнички решенија, успешноста на овој проект е утврдено дека не е доволна, кога од самиот почеток не би биле инволвирани и станарите. Прво со информирање и анкетирање на станарите. Потоа со нивно вклучување и презентација на целокупните анализи и решенија од проектот во соба формирана за демонстрација. Слушањето на нивните барања и желби се клучните прашања за модернизација на еден успешен проект. Затоа Хазука (Hazucha 2010) ќе потенцира дека само оние станари кои се лично инволвирани и уважени во подготовките за модернизација на еден објект, кои се запознати со целта и веруваат во користа и бенефитот, можат да ги разберат идеите и промените во проектот. Тука се поставува прашањето дека при вакви зафати на поголеми реконструкции често доаѓа до конфликти меѓу сопствениците на станови поради недостаток на информации, образование и недостаток на презентации. Во овој пример СОЛАНОВА уште од самиот почеток земени се во предвид причините за неуспех, кои претставуваат резултат на фракторот корисник. Секако тука од самиот почеток се информирани, а воедно и се анализирани прашањата и барањата од самите корисници. Следи заклучок дека овој третман претставува појдовна точка на самиот проект, а воедно и причината за успех. Најбитното сознание, при анкетираните станари е дека 
понезадоволни се од внатрешната клима за време на летниот период отколку во зима. Ова сознание го променува и концептот на модернизација. Во собата за презентација и поставување на прашања од страна на сопствениците, изложени се проекти од системот за вентилација, пресек на надворешен зид, вградување на прозори и врати и сл. По ова појаснување на станарите, тие комплетно се информирани за употребата на новите технологии и системот за механичка вентилација, што е битен фактор за енергетска ефикасност. Но и покрај поголемите напори и вложувањето во едукација на сопствениците дојдено е до заклучок дека сопствениците - корисниците тешко ги менуваат својте навики. Иако заштедите по модернизацијата се големи сепак е продолжено со анкетирање на корисниците при што е увидено дека температурата во становите во грејната сезона е $24,7^{\circ} \mathrm{C}$. Овој пораст во однос на дизајнираната температура од $20^{\circ} \mathrm{C}$, би било потрошувачка преку $50 \%$ од предвидената. После дополнителни брошури и информирање во следната грејна сезона, се постигнува значаен успех.

Зградата се наоѓа во градот Дунајварош кој е 70 км јужно од Будимпешта. Истата е изградена во 1975г. од префабрикувани панели кој претставуваат сендвич систем. Според Хермелинк (Hermelink 2005) првите панелни згради во Унгарија се изградени во Будимпешта во 1954г. Во 70 тите - 80тите години во Унгарија се градат доста голем број на ваков тип на станови од кои денес се регистрирани 726000 станови со панелен систем од кои 508000 се со префабрикуван сендвич систем. Може да се каже дека 13,8\% од Унгарското население живее во ваков тип на станбени згради. Овој вид на градби се типични за земјите од источна Европа поготово во источниот дел на Германија каде се регистрирани 2000000 згради. Климата е континентална, со зими од 15 до $-10^{\circ} \mathrm{C}$. Зградата е со спратност од приземје и седум ката, содржи 42 стана и вкупна бруто површина од 2 742м2. Пресметките за енергетскиот биланс за греење, пред модернизацијата изнесуваат $213 \mathrm{kWh} / \mathrm{m}^{2} \cdot a$, истакнува Хермелинк (Hermelink 2005) .

\section{- Постоечка состојба}

\section{Надворешни зидови}

Sидовите се префрабрикувани сендвич панели во три слоја. Два слоја се бетонски, а во средина е изолација од полистирен. Ваков тип на панелни 
системи е употребуван и кај нас по земјотресот,а тоа е познатиот "Карпош систем". Искуството од употребата и анализите покажуваат дека на краевите од панелите се создаваат сериозни малигни рани или т.н. термички мостови, кои допринесуваат до создавње влага и влажнење на слојот од изолација. Институционално во лабараторијата на Универзитетот за градежна физика во Будимпешта е прикажано дека поради термичките мостови, влагата и вибрациите постои разлика меѓу теоретската и реалната вредност на U фракторот на пропусливост на топлина. Според истражувањата, сознанијата се дека реалната проводливост е за 50\% повисока од теоретската. Причината ја утврдуваат во термичките мостови кои се еднодимензионални трансмисиони загуби од панелите, а реалната U вредност варира од 1,3-2,6 W/M² $\mathrm{K}$ истакнува Хермелинк Hermelink (2005).
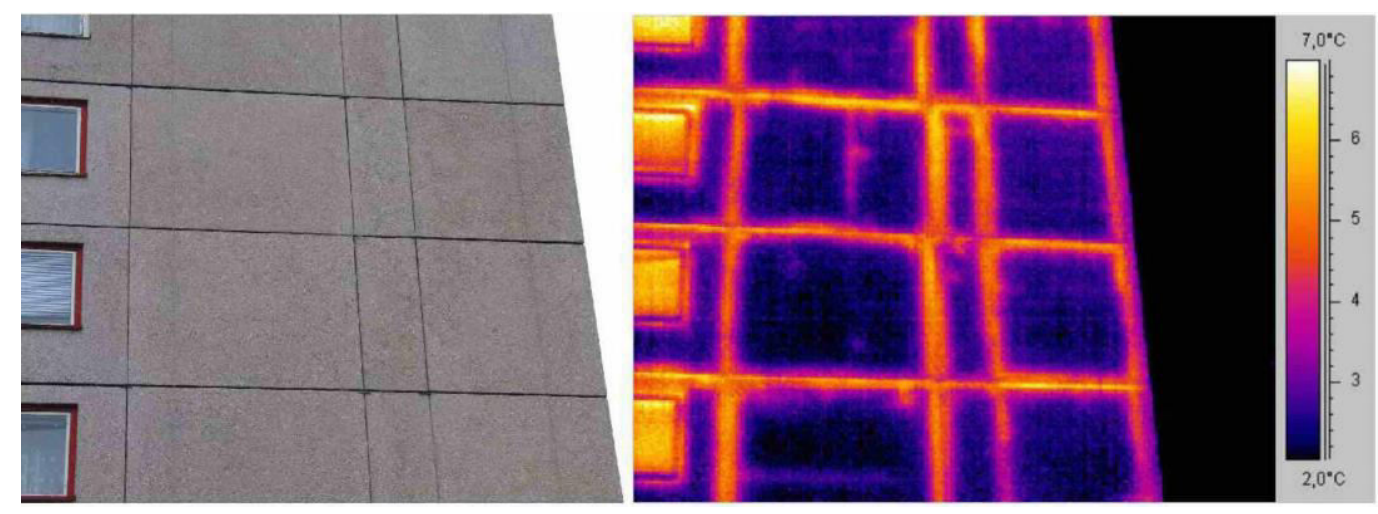

Фигура 39: Поглед на западна фасада со термовизиска камера пред реконструкција Извор: Хермелинк (Hermelink 2005:14)

\section{Прозори}

Според Хермелинк (Hermelink 2005) прозорците се од дрвена рамка со едноструко застаклување со U вредност од 3,2 W/M²K.

\section{Кров}

Кровната конструкција е од бетонска плоча со дебелина од 13см, обвиена со 5 см лесен бетон и 8см изолациски слој. Кровот има проблеми со влага појаснува Хермелинк (Hermelink 2005).

Според Хазука (Hazucha 2010) клучни елементи за модернизацијата се: реконструкција и изолација на обвивката на зградата, прозорци со високи перформанси со тројно застаклување и интегрирани ролетни за заштита од летно прегрејување. Потоа, вградување на механичка ефикасна вентилација со 
систем за рекуперција во секој засебен стан. Сончеви колектори кои овозможуваат $20 \%$ енергија за греење на вода и простор. Создавање на зелен кров и изолација на кров. Модернизацијата резултира во комплетно задоволство кај станарите.

\section{- Ново - Проектирана состојба}

\section{Обвивка на фасада}

Според сите инволвирани субјекти како најадекватно решение е избрана изолација од експандиран полистирен со дебелина од 16см и U вредност =0,19 W/M²K презентира Хермелинк (Hermelink 2005).

\section{Прозори}

Според извршените анализи кај сопствениците и нивните потреби, утврдено е решение кое ќе овозможи заштита од прегрејување во летниот период. Посветено е внимание за избегнување на клима уредите со што ќе се користат пасивни техники и високо засенување од јужната и западната страна. Вградени се ПВЦ прозорски рамки со тројно застаклување и интегрирани ролетни за засенување меѓу прозорските панели. Стаклопакетот во едниот слој е исполнет со аргон и премачкан со рефлектирачки слој. Овие стакла се со високи перформанси презентира Хермелинк (Hermelink 2005).

\section{Кров}

Хермелинк (Hermelink 2005) укажува дека за кровот е посветено внимание да се создаде заедничка површина од зелен кров под кој има изолација од екструдиран полистирен со дебелина од $30 \mathrm{~cm}$ и U вредност од 0,11 W/M²K.

\section{Греење, топла вода, вентилација}

Постоечката состојба на системот за греење е со старост колку и самата зграда. Тоа се грејни тела со состав кој има високи температури од $70-90^{\circ} \mathrm{C}$. По комлетната изолација и модернизација на зградата намалена е потребата од високи температури, па со тоа е намален и бројот на грејните тела и е овозможен состав со ниски температури од $45-60^{\circ} \mathrm{C}$ со вграден термостатски вентил. Заштедата на енергија за греење во првата сезона изнесуа $82 \%$. По анализите и упатствата за употреба на користење на системите со намалување на вентилите и користење на механичка вентилација наместо природна, 
заштедите во втората грејна сезона се подобрени. Вкупната годишна потрошувачка на енергија за греење од $213 \mathrm{kWh} / \mathrm{M}^{2} \mathrm{~K}$ е намалена првата година на $40 \mathrm{kWh} / \mathrm{M}^{2} \mathrm{~K}$, а втората на $29 \mathrm{kWh} / \mathrm{M}^{2} \mathrm{~K}$. Оваа состојба претставува блискост со пасивните објекти забележува Хазука (Hazucha 2010) .

\section{Топла вода}

Според Хазука (Hazucha 2010) снабдувањето на објектот со топла вода има $20 \%$ заштеда, со употребата на обновливи извори - сончеви колектори.

\section{Вентилација}

Вентилацијата претставува најосетлив дел од овој проект и е дизајнирана по примерите на пасивни објекти. За избор и вградување на овој систем анализирани се повеќе аспекти и тоа: инвестициони и операциони трошоци, можности за изведба, деструкции од вградувањето, бучава и оштетувања, можности за простор, заштита од пожар, можност за мултиплицирање, лесна монтажа и употреба и конкурентност на пазарот. На крајот пресметките за буџетот за целата реконструкција изнесуваат $240 € / \mathrm{M}^{2}$ каде инвеститор е заедницата на сопственици со помош на Владата и локалната власт појаснува Хазука (Hazucha 2010).

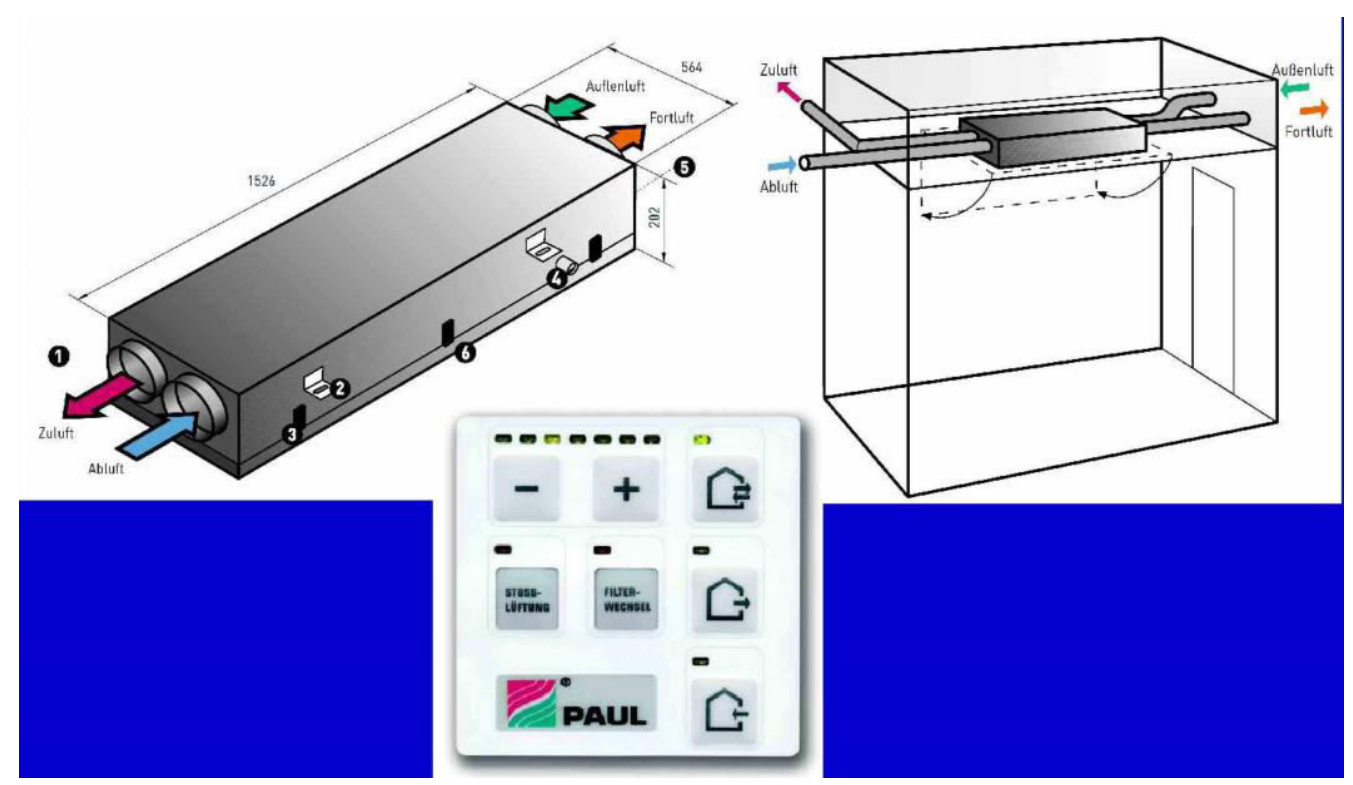

Фигура 40: Проект СОЛАНОВА Решение за вентилационен систем Извор:Хермелинк (Hermelink 2005:30) 


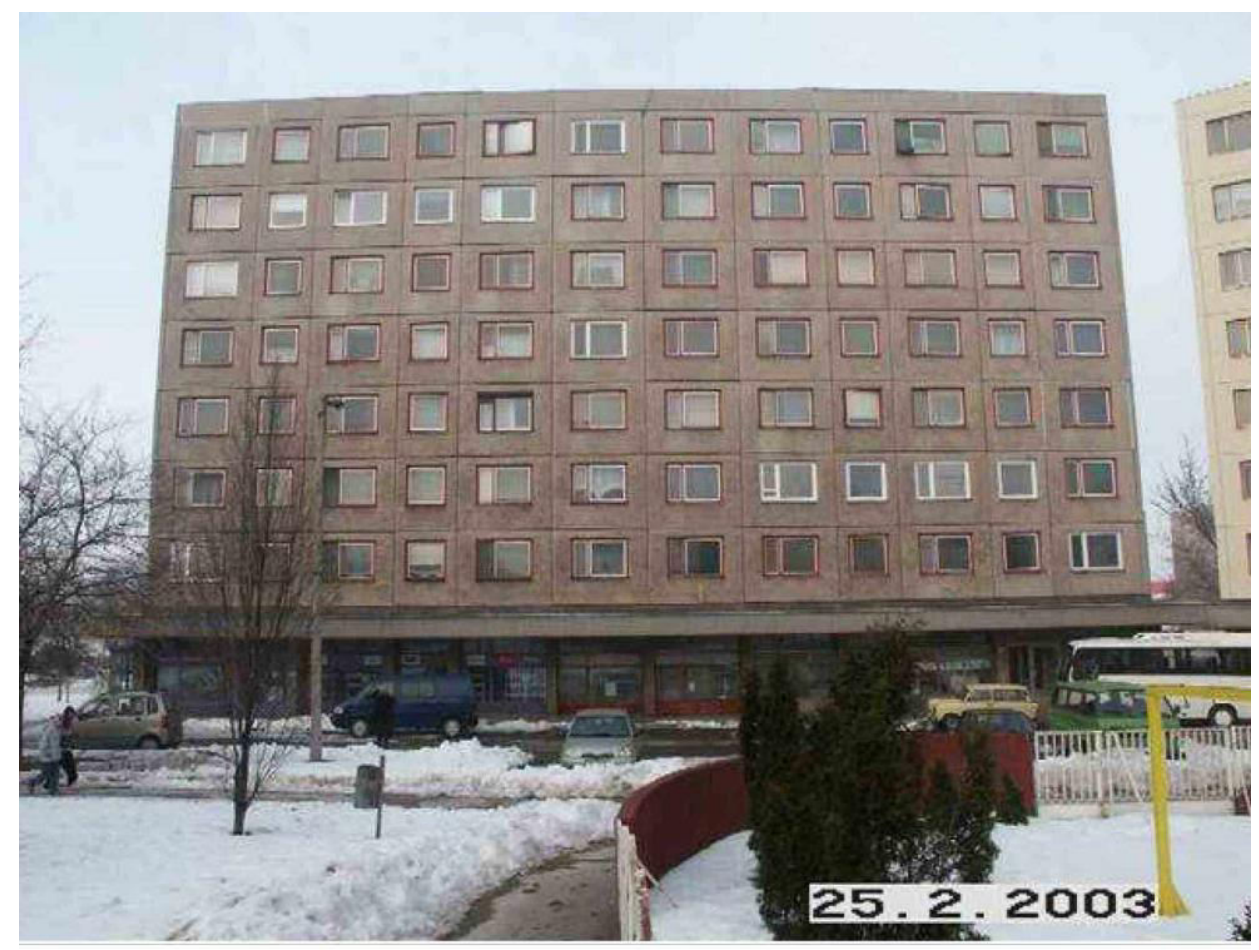

Фигура 41: Проект СОЛАНОВА пред реконструкција поглед - југ Извор: Хермелинк (Hermelink 2005:13)

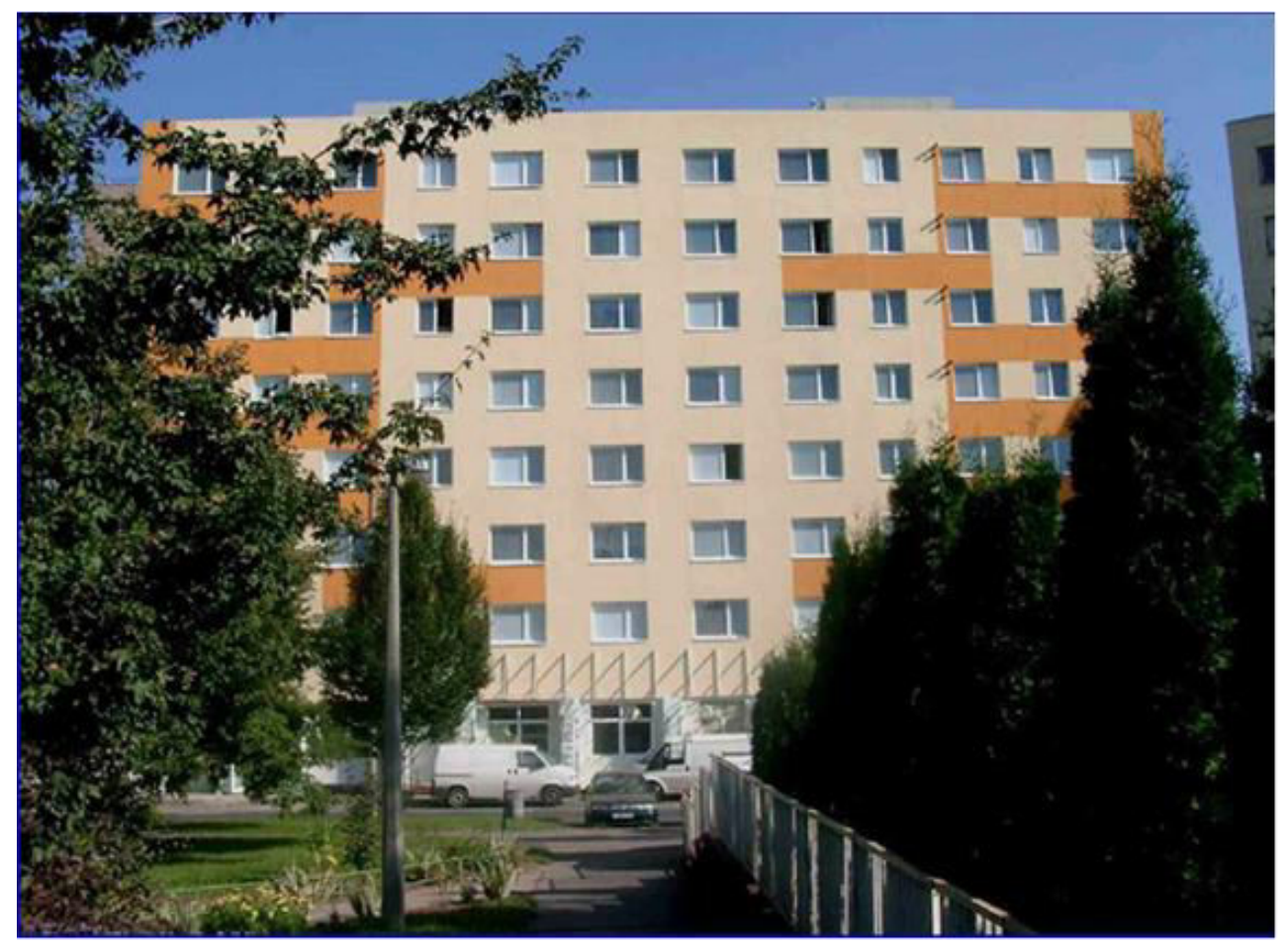

Фигура 42: Проект СОЛАНОВА по реконструкција поглед - југ Извор: Хермелинк (Hermelink 2005:36) 
Табела 2: Споредбена анализа пред модернизација и по модернизација на зградата СОЛАНОВА во градот Дунајварош во Унгарија.

\begin{tabular}{|c|c|}
\hline Пред модернизација & По модернизација \\
\hline 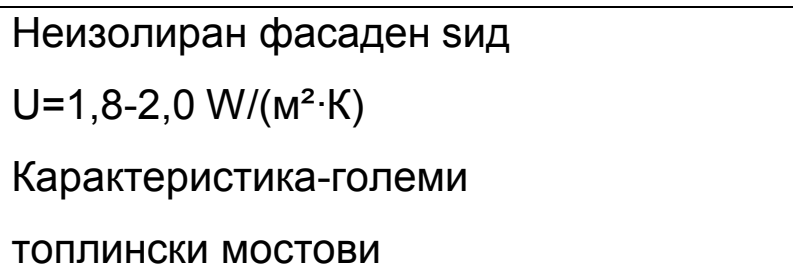 & $\begin{array}{l}\text { Фасадна обвивка изолирана со EPS } \\
\mathrm{U}=0.19 \mathrm{~W} /\left(\mathrm{M}^{2} \cdot \mathrm{K}\right)\end{array}$ \\
\hline $\begin{array}{l}\text { Кров } \\
U=1,3 \mathrm{~W} /\left(\mathrm{M}^{2} \cdot \mathrm{K}\right)\end{array}$ & $\begin{array}{l}\text { Кров со нова изолација од XPS и } \\
\text { додатно зелен кров (заеднички } \\
\text { простор) } U=0,11 \mathrm{~W} /\left(\mathrm{M}^{2} \cdot K\right)\end{array}$ \\
\hline $\begin{array}{l}\text { Прозорци со дрвена дотраена рамка } \\
\text { со едноструко застаклување } \\
\mathrm{U}=3,2 \mathrm{~W} /\left(\mathrm{M}^{2} \cdot \mathrm{K}\right)\end{array}$ & $\begin{array}{l}\text { Нови PVC прозори со троструко } \\
\text { застаклување (2+1) со интегрирани } \\
\text { ролетни за заштита од прегрејување и } \\
\text { докажана зраконепропусност } \\
\text { U=1,1 W/(M²·K) }\end{array}$ \\
\hline Вентилација - природна & $\begin{array}{l}\text { Вентилација со состав за рекуперација } \\
\text { на топлината } 80 \% \text { ефрикасност }\end{array}$ \\
\hline \multirow[t]{2}{*}{$\begin{array}{l}\text { Греење } \\
\text { Грејни тела со високи температури до } \\
90^{\circ} \mathrm{C} \\
\text { Годишна потрошувачка } 213 \text { kWh/м² }\end{array}$} & $\begin{array}{l}\text { Греење } \\
\text { Намален бр. На грејни тела, } \\
\text { поставување на термостат, термо } \\
\text { состав со температури до } 60^{\circ} \mathrm{C} \\
\text { Годишна потрошувачка } 29 \mathrm{kWh} / \mathrm{M}^{2}\end{array}$ \\
\hline & $\begin{array}{l}\text { Обновливи извори со соларни панели } \\
\text { кои обезбедуваат } 20 \% \text { од топла вода и } \\
\text { греење }\end{array}$ \\
\hline
\end{tabular}

Извор: Хазука (Hazucha 2010)

Табела 3: Го искажува задоволството на сопствениците, за собната температура

\begin{tabular}{|l|c|c|}
\hline & Пред модернизација & По модернизација \\
\hline Многу незадоволни & $9,1 \%$ & $0 \%$ \\
\hline Незадоволни & $12,1 \%$ & $0 \%$ \\
\hline
\end{tabular}




\begin{tabular}{|l|c|c|}
\hline Неутрално & $30,3 \%$ & $2,9 \%$ \\
\hline Задоволни & $33,3 \%$ & $31,4 \%$ \\
\hline Многу задоволни & $15,2 \%$ & $65,7 \%$ \\
\hline
\end{tabular}

Извор: Хазука (Hazucha 2010)

6.2 Модернизација на постоечка станбена зграда на ул. Макарт - Линц, Австрија

Станува збор за реконструкција и модернизација на постоечка станбена зграда која датира од 1957/58 година. Се работи за намалување на енергија за греење до 90\% или модернизација со т.н. фрактор 10. Според APX+MOP(ARCH+MORE 2007) овој пример на реконструкција е прв пример за класична зграда реконструирана и модернизирана по принципите на пасивен објект во Австрија.

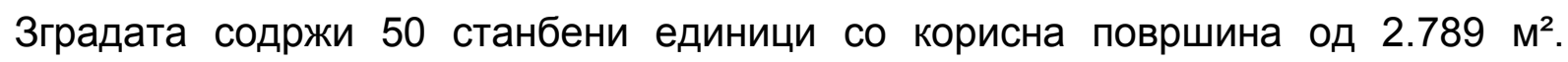
Поставена е линиски на бучната и загадена улица Макарт, која претставува главна рута до ценарот на Линц. Станбените единици се ориентирани запад исток, со тоа што северниот калкан е отворен, додека јужниот се граничи со блокот во продолжение. Катноста на објектот е со 5 ката. Поради проширување на балконските простори со нов концепт на фасадни панели, зградата добива проширена корисна површина од $3.106 \mathrm{M}^{2}$. Автор на решението на новите фасадни панели е архитект Јохан Ашауер (Johan Aschauer 2006). Карактеристично е за новодобиеното решение на фасада дека пред се произлегува од еколошки потреби. Авторот ја зема во обзир бучавата и загадувањето предизвикано од улицата Макарт. Потоа анализирана е неискористеноста на балконите, па одтука и заклучокот за проширување и затварање на балконските простори. Резултатот е преобликување на фасадата во еден современ архитектонски израз. Според проектот приземјето и првиот кат функционираат како нискоенергетски објект, додека останатите катови се по принципите на пасивен објект истакнува APX+MOP (ARCH+MORE 2007). Клучни елементи за модернизацијата се: проширување на балконите и воедно нивно имплементирање во корисен станбен простор. Комплетно вградување на нова фасадна обвивка со префабрикувани зидни фасадни панели. Вградување на механичка вентилација, со искористување на топлината од одпадниот воздух. 
Борковиќ (Borkovič н.п. : 5) потенцира дека целта на модернизацијата на зградата на ул. Makartsrasse e :

- " Смалување на трошоците за енергија на минимум

- Зголемување на квалитетот на внатрешниот воздух

- Функционално искористување на просторот, зголемување на стандардот

- Примена на нови иновативни технологии на префрабрикација

- Реконструкција без иселување на станарите "

Проектот е вреден да послужи како пример за модернизација на овој тип на објекти и има освоена награда од Енерџи стар (Energy star 2006) за најуспешно зголемување на енергетската ефикасност. Покрај тоа има добиено австриска државна награда за архитектура и одржлив развој.
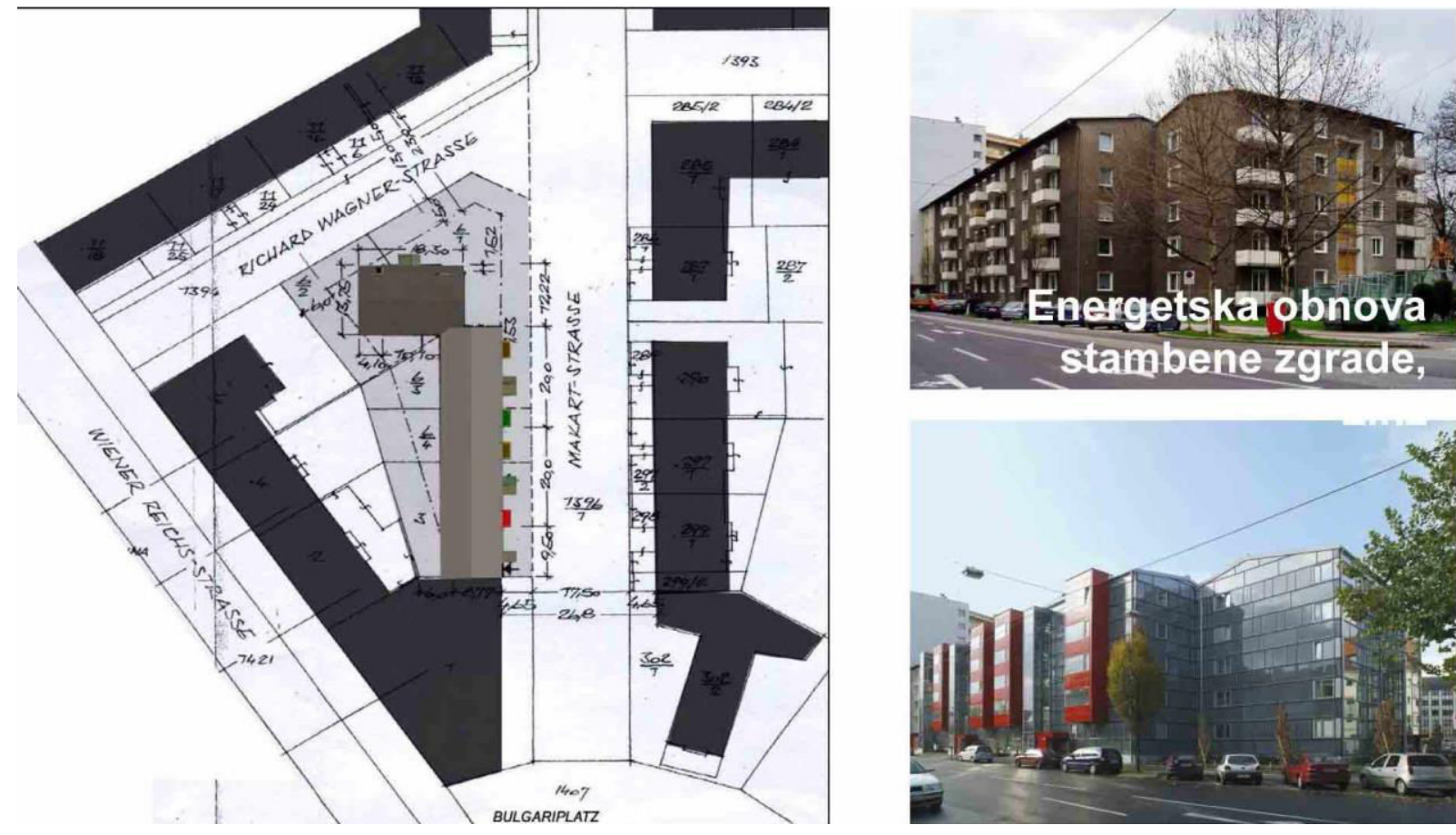

Фигура 43: Реконструкција со ФАКТОР 10 - Arch + More,DI Ingrid Domenig - Meisinger Johan Aschauer - автор на фрасадно решение Извор: Борковиќ (Borkovič н.п.:3)

\section{Надворешен зид}

Објектот е изведен од лесен бетон кај надворешните зидови со армирано бетонска меѓукатна конструкција. Пред воопшто да се реши новата обвивка на фрасада извршени се атести на постоечката констркција со статички анализи за издржливоста на постоечките sидови и меѓукатна конструкција во контекст на 
монтажа и носивост на новопроектираните фрасадни панели. Новопроектираниот фасаден панел се состои од неколку слоја и претставува мошне иновативно и современо решение за обвивка на фасада. Првиот слој се состои од темно стаклен панел, позади кој струи воздух - празнина за вентилација и заштита на следниот слој, кој претставува соларен чешел. Сончевата радијација се апсорбира во системот и создава разлика во температура меѓу внатрешниот и надворешниот простор како еден вид тампон зона. Наредниот слој е дрвен панел позади кој е поставена термоизолација со варијабилна димензија, воглавно 40мм од камена волна. Вкупната дебелина на панелот изнесува 131,4мм претставено од APX+MOP (ARCH + MORE 2007).

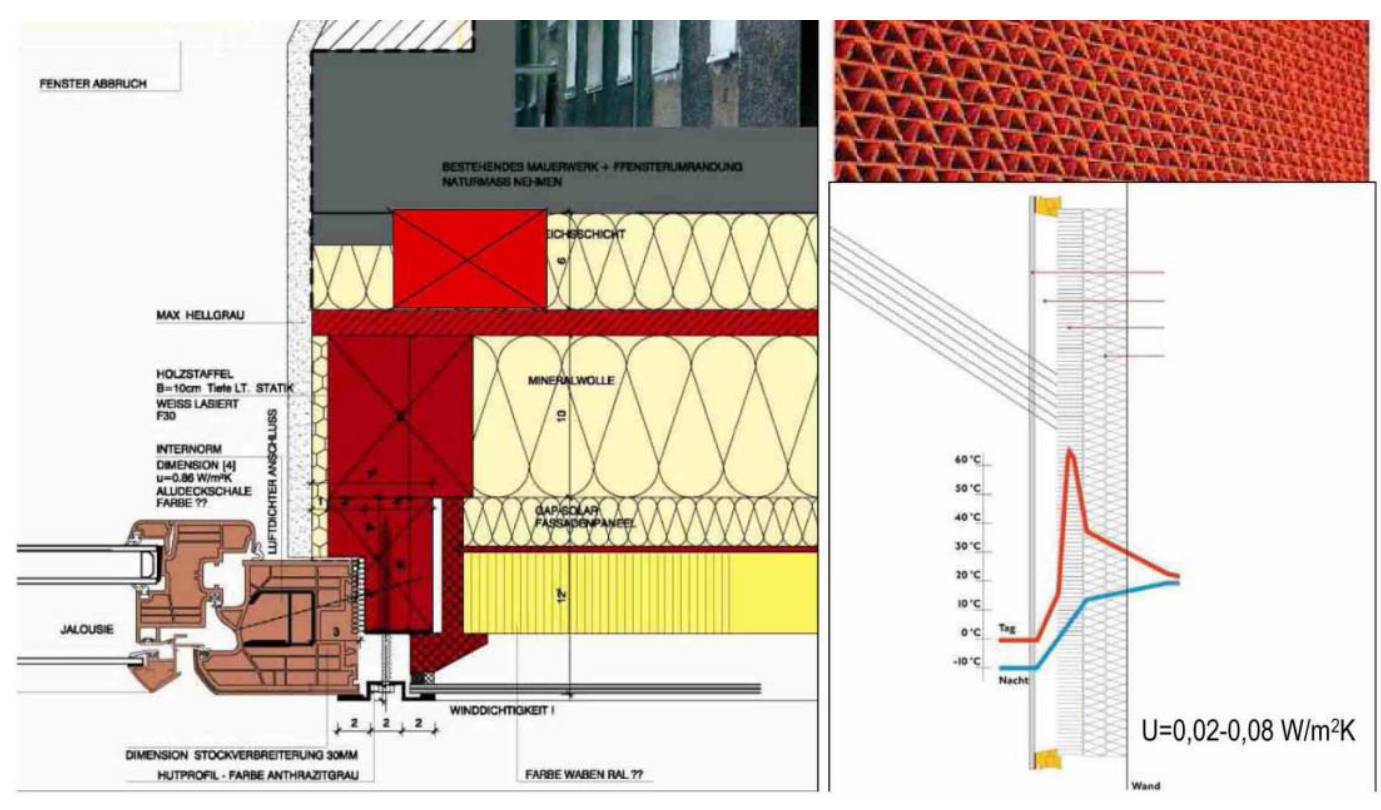

Фигура 44: Детал на надворешен зид со прозор - автор, Johan Aschauer Извор: Борковиќ (Borkovič н.п.:7)

\section{Прзорци}

И во овој пример на реконструкција, старите дрвени прозорци се заменети со нови, интегрирани во фасадната панелна завеса каде стаклопакетот е решен со трослојно стакло со интегрирани ролетни за заштита од сончево прегрејување. U фракторот изнесува 0,86 W/M² K според APX+MOP (ARCH + MORE 2007).

\section{Реконструкција на балконите}

Како што е погоре наведено, една од главните причини за изборот на фрасадно решение и целиот затворен концепт на панелен систем е поради постоечките 
балкони кои не се соодветно искористени заради непријатноста од загадената и бучава улица. Зградата нема лифтовска содржина, но по реконструкцијата вметната е лифтовска доградба.

\section{Механичка вентилација}

Секој стан е обезбеден со механичка вентилација која обезбедува свеж воздух без да се отвараат прозорци. Со тоа се намалени вентилационите загуби. Вентилацијата има топлински повраток, рангиран до 70\%. За изборот на овој тип вентилација анализирани се повеќе аспекти:

- Високоефикасен систем на топлински повраток

- Тивок и соодветен систем за користење во станбени единици

- Инсталирање во проблематични делови

- Цената на чинење

- Технички докажан избор за примена во Австрија

\section{Комуникација со станарите}

За време на фразата планирање на проектот, создадена е организирана комуникациска атмосфера со сопствениците на станови. Благодарение на отворени дискусии и презентации, проектот е целосно прифатен од нивна страна, иако е прв пример од овој вид на реконструкции во Австрија.
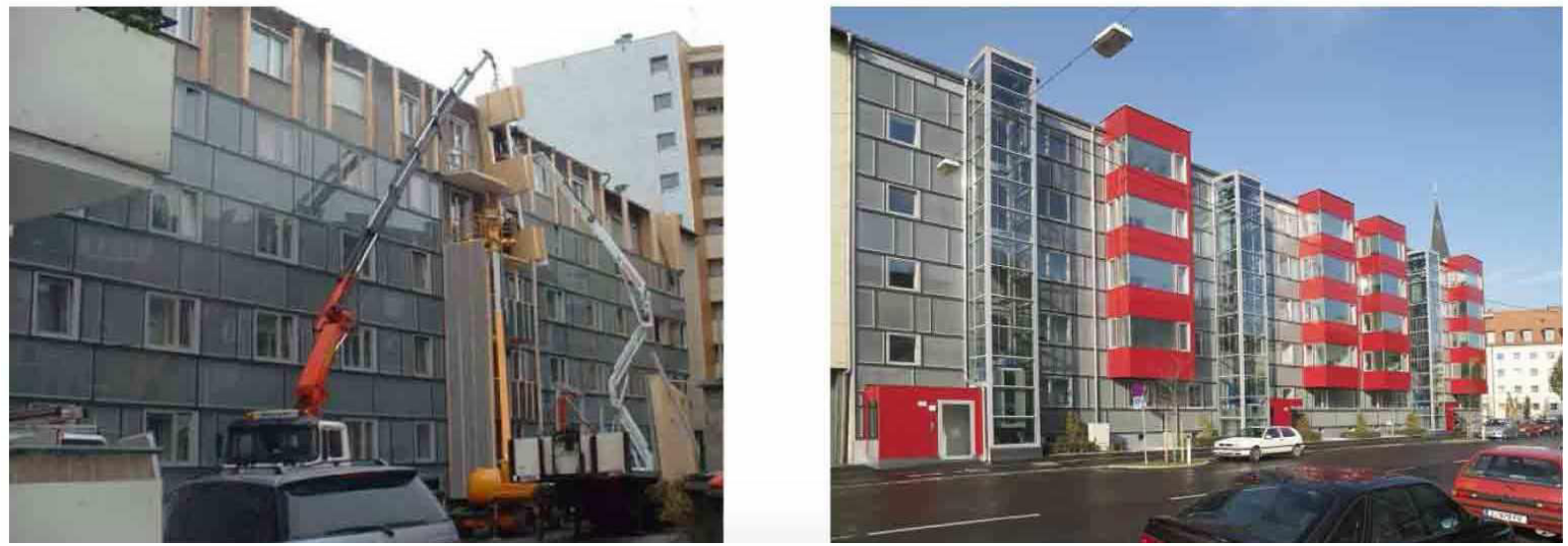

Фигура 45: Монтажа на нови фасадни панели Извор: Борковиќ (Borkovič н.п.:6) 


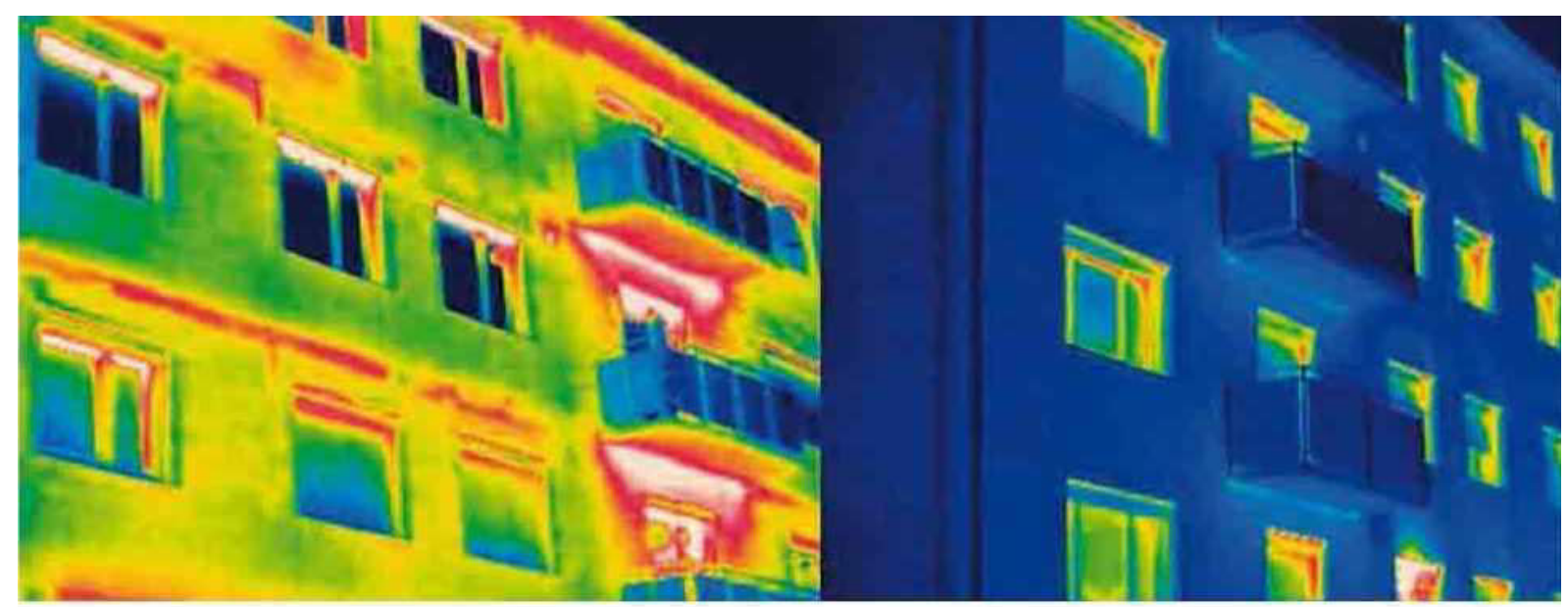

Фигура 46: Термографски снимки

Извор: Борковиќ (Borkovič н.п:5)

Табела 4: Споредбена анализа пред модернизација и по модернизација на зградата во Линц ( ул. Макарт, Австрија )

\begin{tabular}{|l|l|}
\hline Пред модернизација & По модернизација \\
\hline $\begin{array}{l}\text { Емисии на СО2 на годишно ниво } \\
\text { изнесуваат - } 160.000 \mathrm{~kg}\end{array}$ & $\begin{array}{l}\text { Емисии на СО2 на годишно ниво } \\
\text { изнесуваат - } 14.000 \mathrm{~kg}\end{array}$ \\
\hline $\begin{array}{l}\text { Потребите за греење на годишно ниво } \\
\text { изнесуваат - } 179 \mathrm{kWh} / \mathrm{M}^{2}\end{array}$ & $\begin{array}{l}\text { Потребите за греење на годишно ниво } \\
\text { се намалени на - } 14,4 \mathrm{kWh} / \mathrm{m}^{2}\end{array}$ \\
\hline $\begin{array}{l}\text { Годишни топлински загуби } \\
-118 \mathrm{~W} / \mathrm{M}^{2}\end{array}$ & $\begin{array}{l}\text { Годишни топлински загуби } \\
-11,3 \mathrm{~W} / \mathrm{m}^{2}\end{array}$ \\
\hline
\end{tabular}

Разлика во Uкоефициенти пред и после модернизација

\begin{tabular}{|c|c|}
\hline Обвивка на фрасада $U=1,2 \mathrm{~W} / \mathrm{M}^{2} \mathrm{~K}$ & $\begin{array}{l}\text { Обвивка на фрасада } \\
\mathrm{U}=0,082 \mathrm{~W} / \mathrm{M}^{2} \mathrm{~K} \text { (mSolareinrag) }\end{array}$ \\
\hline Подрумски плафон U=0,9W/M²K & $\mathrm{U}=0,21 \mathrm{~W} / \mathrm{M}^{2} \mathrm{~K}$ \\
\hline Прозорци U=3,09W/M²K & Прозорци U=0,869W/M²K \\
\hline Грејна површина П=2756м² & Грејна површина П=3106м² \\
\hline
\end{tabular}

Извор: Изработено од Катерина Петрушевска ,

според Борковиќ (Borkovič н.п:6); APX+MOP (ARCH+MORE 2007:13)

Според добиената цел од т.н. фрактор 10 годишните трошоци за просечен стан од $60 \mathrm{M}^{2}$, се намалени од $40 €$ месечни трошоци на $4,7 €$.

APX+MOP (ARCH+MORE 2007) ги образложува мотивациите и цената на чинење за реконструкција на зградата, па од тука вложените трошоци за 
конвенционална реконструкција изнесуваат $608,68 € / \mathrm{M}^{2}$, додека за реконструкција според принципите на пасивни куќи трошоците би изнесувале $774,00 € / \mathrm{M}^{2}$. Истите појаснуваат и дека главни мотивации за реконструкција од ваков тип се:

- Реновирање без раселување на сопствениците - станарите

- Високите трошоци за енергија за греење

- Желба за фрормирање на пилот проект кој ќе послужи за пример кон останати објекти

- Интензивни подготовки, вклучувајќи претставници на станарите

- Усреќување и на најскептичните станари

- Механичка вентилација која се регулира засебно за секоја просторија соба, која ќе овозможи квалитет на живеење поготово кај алергични жители

- Можност за користење на балконскиот простор кој претходно бил вон употреба и премногу нечист

- Планирање на објекти со мала потрошувачка на енергија

6.3 Македонски пример на реконструкција на постоечки станбени згради

УСАИД и Хабитат во Порта3 (2010) има презентирано план и реализација за реновирање на повеќе постоечки станбени згради на територијата на $P$. Македонија, според принципите на енергетско ефикасни објекти. Целите на овој проект се да им се помогне на домаќинствата што живеат во повеќесемејни станбени згради, да се подигне стандардот, културата на одржливост, заштита од климатските промени, намалување на емисии на СО2. Енергетско ефикасни мерки при реконструкција се предвидени на 26 згради во 7 општини. Спроведувањето на енергетско ефикасни градежни интервенции во зградите е преку воспоставување на обновлив фонд од кој ќе се обезбедат заеми на заедниците на сопственици. Овој проект вклучува обука, како и нови "зелени" работни места на заедниците на станари. 


\subsection{1 Модернизација на станбена зграда на}

ул. Лазар Поп Трајков бр.34 Скопје, Македонија

Во овој пример на обнова, се работи за станбен објект во населбата Автокоманда кој е изграден во 1960г. Истиот е со висина П+1, содржи четиринаесет станбени единици, со три влеза. На секој кат се распоредени по три станбени единици, а вкупната станбена површина изнесува 904,7м². Хабитат (Habitat 2013) во неделата на енергетска ефикасност го презентира пилот проектот чии аудит е претставен од страна на чешка компанија. Утврдено е дека објектот е приклучен на централно греење во 2008г. Претходно, греењето било спроведено со електрични печки каде што покрај големите трошоци на електрична енергија забележан е дисконфорт на температурата на внатрешниот воздух, како и појава на влажни зидови и мувла. Според Хабитат (Habitat 2010) за овој пилот проект изработен е:

- Проект на постоечка состојба

- Анализирана е потрошувачката на електрична енергија

- Пет дневна обсервација на селектирани станови

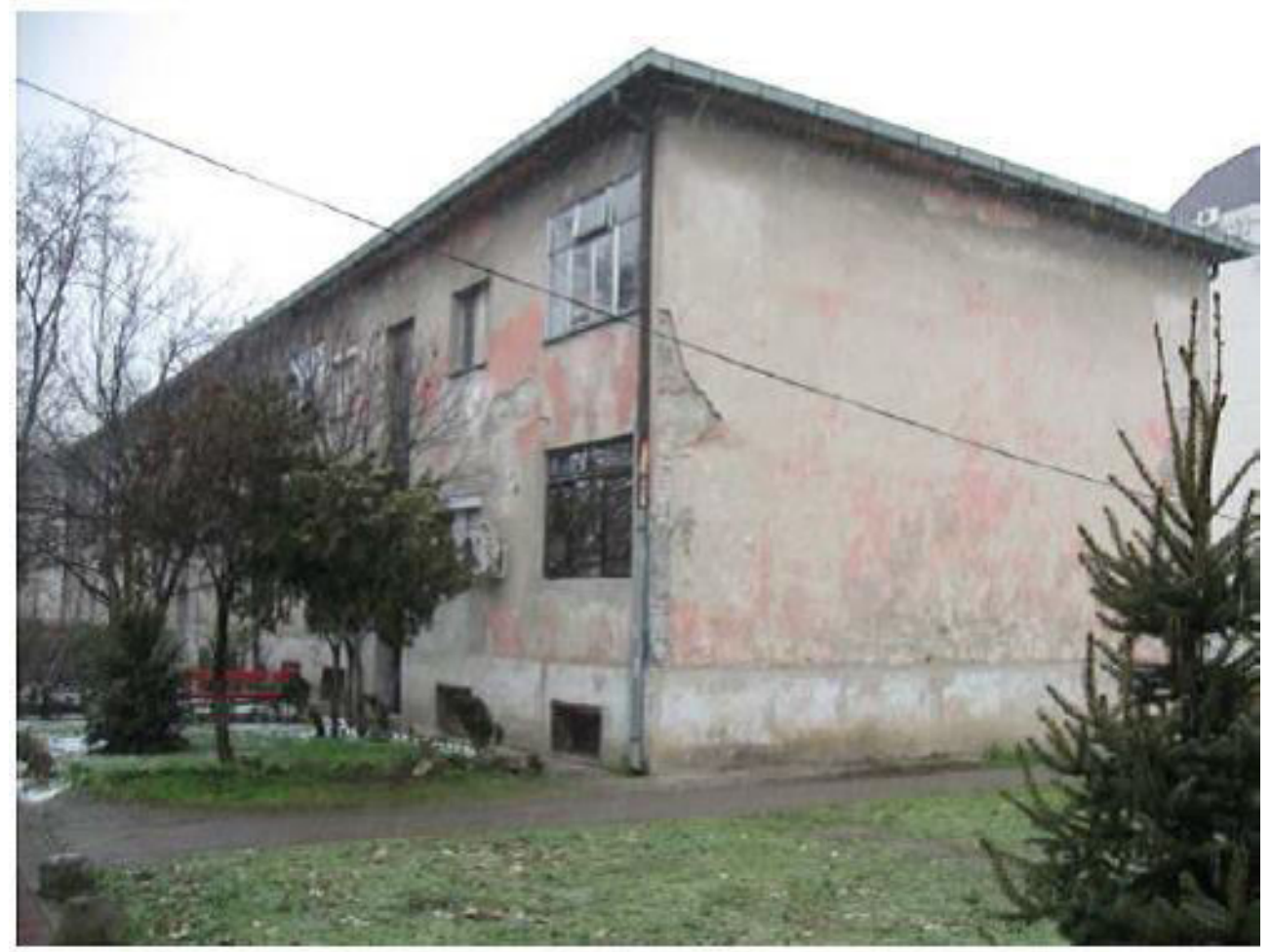

Фигура 47: Постоечка станбена зграда во Автокоманда Извор: Хабитат (Habitat 2010) 
За пресметка и проценка на модернизацијата, користени се две методологии:

1. Направена е разработка на обвивката на фасада или пресметани се коефрициентите на премин на топлина - U[W/(m².K)]. Од тука се добиени постоечките $U$ коефициенти и поставена е една компарација со тогашните македонски легислативи како и со чешки. Компарацијата со чешки коефициенти на премин на топлина е од причина што проектот го разработува чешка компанија. Добро е да се напомене дека тогашните македонски легислативи не се во функција се до правилникот за енергетски карактеристики на згради со примена од оваа 2014г.

2. Вториот метод на проценка е потрошувачката на енергија на годишно ниво.

Анализирани се сите постоечки градежни елементи како: надворешни sидови, прозорци, кров и подови. Проценета е состојбата како и коефициентот за премин на топлина U. Истиот е споредуван со максимално дозволениот коефициент кој ќе задоволи одредени енергетско ефикасни барања. Предложен е проект на модернизација со подобрување на обвивката на фасада, термичка санација на таванската и кровната конструкција, со нов покривач и замена на прозорците и вратите на фасада. Според Хабитат (Habitat 2010) донесени се следните заклучоци:

\section{Надворешни зидови}

Постоечките зидови се изведени од полна тула $12 / 25 / 6 \mathrm{~cm}$, и по 2,5cм надворешен и внатрешен малтер. Надворешниот малтер поради предизвикана влага е во лоша состојба. Дебелината на надворешниот sид изнесува д=30см со постоечки коефициент на премин на топлина $\mathrm{U}=1,63 \mathrm{~W} / \mathrm{m}^{2} \cdot \mathrm{K}$. Според чешките стандарди, коефициентите на премин на топлина за надворешен зид изнесуваат $U=0,38-0,25 \mathrm{~W} / \mathrm{m}^{2} \cdot \mathrm{K}$. Македонскиот коефициент за надворешен зид во тоа време изнесува 0,40, а денес е усвоен $\mathrm{U}=0,35 \mathrm{~W} / \mathrm{m}^{2} \cdot \mathrm{K}$. Од тука се предлага облога изолирана со Композитни Системи за Надворешна Термичка Изолација од експандиран

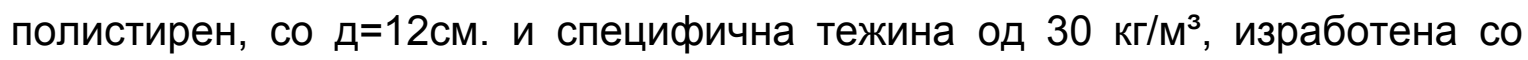
завршен акрилен малтер. 


\section{Прозорци и врати на фасада}

Составот и материјалот од кои се прозорските рамки се разновидни. Првичните или постоечките кои се и најбројни се од дрвени двоструки рамки, со еднослојно застаклување. Според авторите на аудитот за Хабитат (Habitat 2010) проценката на $U$ коефициентот изнесува $U=2,4 \mathrm{~W} / \mathrm{m}^{2} \cdot \mathrm{K}$.

Седум прозорци од оваа зграда се заменети со ПВЦ рамки и двослојно застаклување. Постојат и заградени балкони претворени во кујнски простории застаклени со еднослојно стакло во метални рамки. Состојбата на прозорците е претставена како, лошо и добро одржувана од страна на станарите. Кај скалишното јадро поставени се дрвени рамки со еднослојно застаклување со многу скршени стакла од каде се предизвикуваат дополнтелни загуби. Во овој дел коесициентот е проценет на $\mathrm{U}=4,5 \mathrm{~W} / \mathrm{m}^{2} \cdot \mathrm{K}$, а според чешки стандарди се предлага де изнесува $\mathrm{U}=3,5-2,3 \mathrm{~W} / \mathrm{m}^{2} \cdot \mathrm{K}$. Останатите прозорски елементи кои се делови од станови се предлага да се обноват со нови, ПВЦ рамки со четири комори, две гуми и термопан 4/14/4мм co U=1.7-1,2W/m2K.

\section{Подови}

Подот помеѓу приземјето и подрумот е од неизолирана "Авраменко" меѓукатна конструкција со процена за $\mathrm{U}=1,75 \mathrm{~W} / \mathrm{m} 2 \mathrm{~K}$. Препорачана вредност за овој вид на конструкции изнесува $\mathrm{U}=0,35 \mathrm{~W} / \mathrm{m} 2 \mathrm{~K}$. Се предлага и употребена е изолација од минерална волна со дебелина д=8см.

\section{Кров}

Постоечкиот кров е од дрвена конструкција покриен со керамиди кои се во лоша состојба. Покривната конструкција е со старост од педесет години и на многу места оштетена.Таванските простории се негреани и со голема влага од протекувања на оштетениот покривач. Протекувањата ја уништуваат дрвената граѓa, а влагата продира во становите. Проценет е коефициент за премин на топлина $\mathrm{U}=4,5 \mathrm{~W} / \mathrm{m} 2 \mathrm{~K}$. Се препорачува замена на кровната конструкција и нов покривач со изолација од минерална волна со дебелина на слојот од д=22см. 


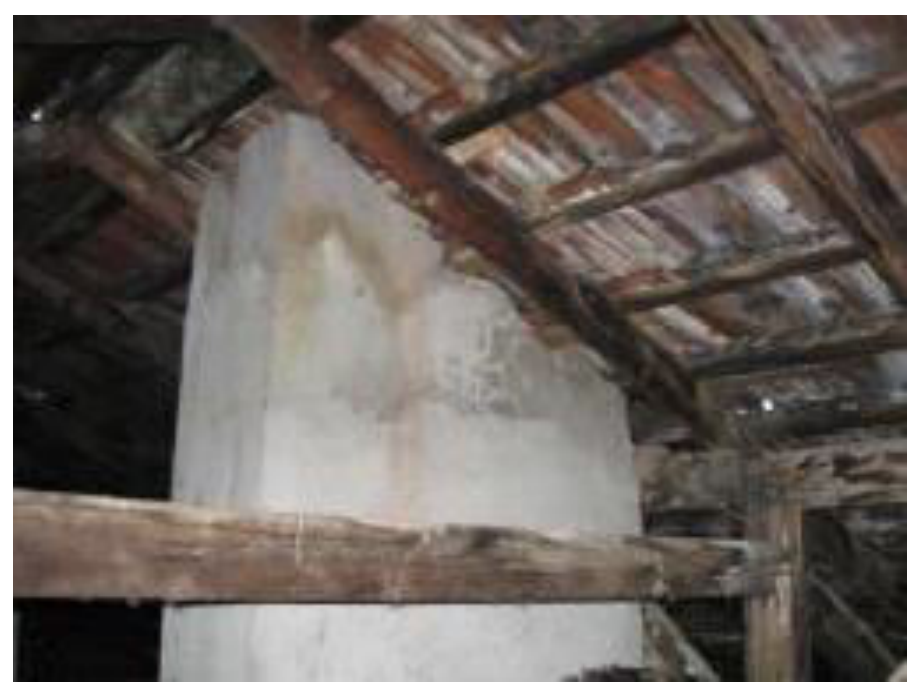

Фигура 48: Состојба на кров

Извор: Хабитат (Habitat 2010)

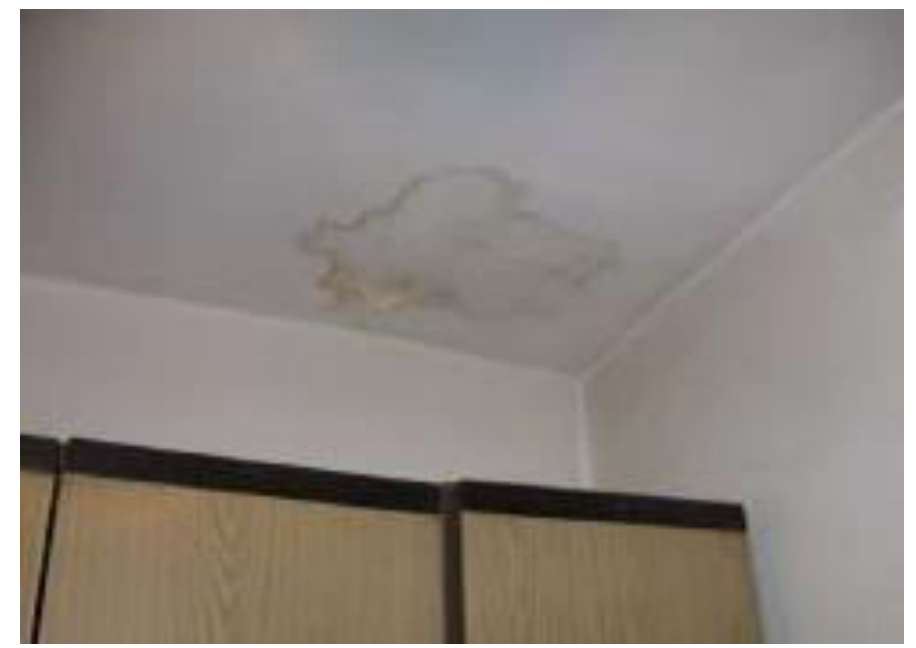

Фигура 49: Протекувања кај станови Извор: Хабитат (Habitat 2010)

Според Хабитат (Habitat 2010) потрошувачката на енергија за греење во постоечката состојба е проценета на $277 \mathrm{kWh} / \mathrm{m}^{2} a$. Според енергетските сертификати спаѓa во "G" класификација. Ова го карактеризира објектот како екстремно неефикасен истакнува Хабитат (Habitat 2010). Со препорачаната реконструкција предвидено е намалувањето на потрошувачката на енергија за 50\%. Проценките за планираната ивестиција се од $63000 €$. По обновата би требало објектот да е во "С" класификација во енергетскиот сертификат со намалена потрошувачка која ќе изнесува $120 \mathrm{kWh} / \mathrm{m}^{2} a$. Хабитат (Habitat 2013) на неделата за енергетска ефикасност истакна дека по реконструкцијата се зголемува температурата во становите за $4^{\circ} \mathrm{C}$, но нема мерки на заштеда на енергија за греење од страна на централниот систем заради не инсталирање на потребните мерачи на грејните вентили. Од тука 
постигнат е само конфорт. Во овој случај на модернизација не е предвидена ниту инсталирана механичка вентилација.

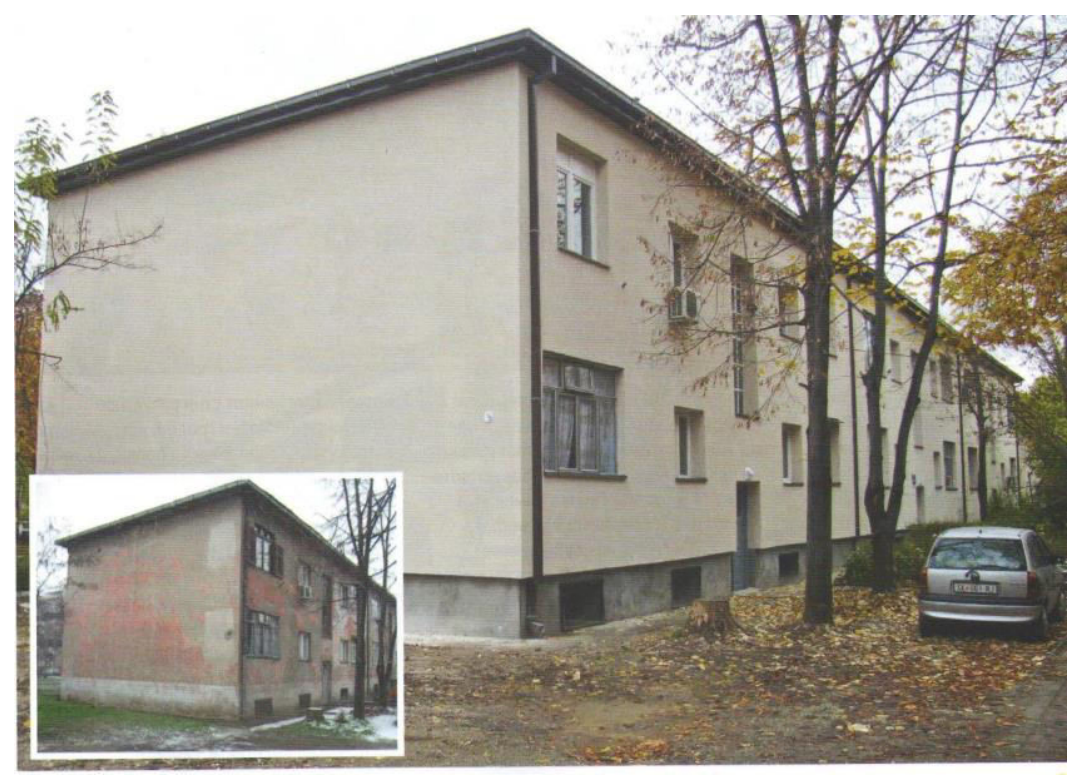

Фигура 50: Реконструкција на станбена зграда во Автокоманда Извор:Порта 3 (2011:21)

Табела 5: Спредбена анализа пред и по реконструкција на станбената зграда на ул. Лазар Поп Трајков бр.34 Скопје, Македонија

\begin{tabular}{|c|c|}
\hline Пред модернизација & По модернизација \\
\hline $\begin{array}{l}\text { Неизолиран фрасаден sид } \\
\mathrm{U}=1,63 \mathrm{~W} /\left(\mathrm{M}^{2} \cdot \mathrm{K}\right)\end{array}$ & 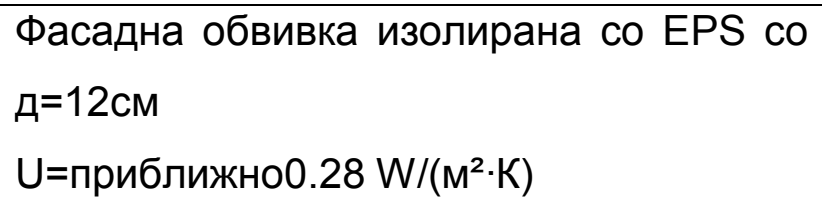 \\
\hline $\begin{array}{l}\text { Кров } \\
U=4,5 \mathrm{~W} /\left(\mathrm{M}^{2 *} \mathrm{~K}\right)\end{array}$ & $\begin{array}{l}\text { Кров со нова изолација минерална } \\
\text { волна со д=22см } U=(\text { н.п. }) \mathrm{W} /\left(\mathrm{M}^{2} \cdot \mathrm{K}\right)\end{array}$ \\
\hline $\begin{array}{l}\text { Прозорци со дрвена дотраена рамка } \\
\text { со едноструко застаклување } \\
\mathrm{U}=2,4 \mathrm{~W} /\left(\mathrm{M}^{2} \cdot \mathrm{K}\right)\end{array}$ & 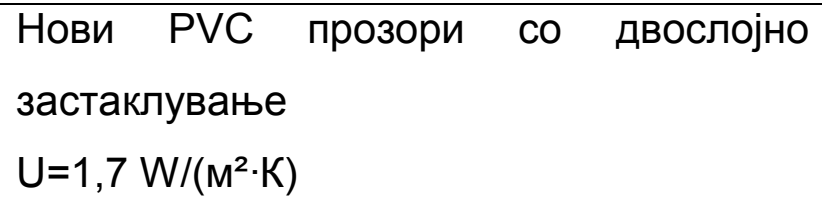 \\
\hline $\begin{array}{l}\text { Греење } \\
\text { Годишна потрошувачка: } 277 \text { kWh/M² }\end{array}$ & $\begin{array}{l}\text { Греење - Годишна потрошувачка, } \\
\text { проектирана: } 120 \text { kWh/m² }\end{array}$ \\
\hline Вентилација - природна & Вентилација - природна \\
\hline
\end{tabular}


6.4 Разгледување на резултатите и споредба меѓу референтните примери

Од претходно наведените и разгледувани три примери на модернизација на постоечки станбени згради, може да се заклучи дека за сите објекти, тенденцијата е намалувањето на премин на топлина преку трансмисија од потопла кон поладна средина и обратно. Методологијата на решение за проблемот е преку пресметка и исполнување на максимално поставените $U$ коефициенти на премин на топлина. Пред превземање на било какви мерки во сите референтни примери направена е студиозна анализа за постоечката состојба и потрошувачка на енергија во објектите. Од тука во табела бр. 6 може да се спореди годишната потрошувачка на енергија за греење:

Табела: 6 Потрошувачка на енергија за греење со класификација во енергетски сертификат ( постоечка состојба)

\begin{tabular}{|c|c|c|}
\hline $\begin{array}{l}\text { Станбена зграда } \\
\text { Соланова, Унгарија }\end{array}$ & $\begin{array}{l}\text { Станбена зграда на ул. } \\
\text { Макарт, Австрија }\end{array}$ & $\begin{array}{l}\text { Станбена зграда на ул. } \\
\text { Лазар ПопТрајков - } \\
\text { Автокоманда, } \\
\text { Македонија }\end{array}$ \\
\hline $213 \mathrm{kWh} / \mathrm{M}^{2}$ & $179 \mathrm{kWh} / \mathrm{M}^{2}$ & $277 \mathrm{kWh} / \mathrm{M}^{2}$ \\
\hline $\mathbf{F}$ & $\mathbf{E}$ & $\mathbf{G}$ \\
\hline
\end{tabular}

Извор:Катерина Петрушевска според податоци од Хазука (Hazucha 2010); APX+MOP (ARCH+MORE 2007); Хабитат(Habitat 2013)

Пристапот на модернизацијата зависи од повеќе фактори. Како на пример кое ниво на заштеда сакаме да го постигнеме, можностите за санација на објектот, потребите на станарите, реализирање на европското реконструкционо сценарио според европската директива. Развој и интегрирање на енергетско ефикасен дизајн, но секако одлучувачки е финансискиот буџет. Мерките за обновата се утврдуваат однапред со преходно планирање. Проектираната заштеда на енергија за греење на годишно ниво, за трите референтни примери може да се види во табела бр.7: 
Табела 7: Потрошувачка на енергија за греење со класификација во енергетски сертификат ( проектирана состојба)

\begin{tabular}{|c|c|l|}
\hline $\begin{array}{l}\text { Станбена зграда } \\
\text { Соланова, Унгарија }\end{array}$ & $\begin{array}{l}\text { Станбена зграда на ул. } \\
\text { Макарт, Австрија }\end{array}$ & $\begin{array}{l}\text { Станбена зграда на ул. } \\
\text { Лазар ПопТрајков - } \\
\text { Автокоманда, } \\
\text { Македонија }\end{array}$ \\
\hline $21 \mathrm{kWh} / \mathrm{M}^{2}$ & $17 \mathrm{kWh} / \mathrm{M}^{2}$ & $120 \mathrm{kWh} / \mathrm{m}^{2}$ \\
\hline $\mathbf{A}$ & $\mathbf{A}$ & $\mathbf{D}^{*}$ \\
\hline
\end{tabular}

Извор:Катерина Петрушевска според податоци од Хазука (Hazucha 2010); APX+MOP

(ARCH+MORE 2007); Хабитат(Habitat 2013)

По модернизацијата на европските примери се јавува потреба од постреконструктивна евалуација на придобивките од превземените енергетско ефикасни мерки. Анализите се направени во период од две години. Од табела 8 и 9 може да се увиди разликата на потрошувачката на годишно ниво, која процесира низ период од две години по т.н. фраза на користење. Со поставеување на упатства за користење на системите за греење, со намалување на вентилите и користење механичка вентилација наместо отварање прозорци, состојбата се корегира. Според Хазука (Hazucha 2010) успешноста на европските примери е најмногу заради континуирана соработка со корисниците, заради точно проектирани мерки како и корекции врз истите. На овој начин енергетската ефикасност се насочува кон правилен развој. Во македонскиот случај, според примерот може да се заклучи дека овој проблем моментално стагнира.

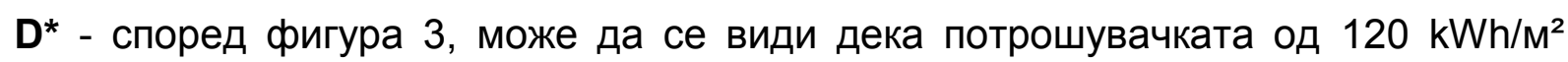
одговара за класификација D. Но, за чешките стандарди проектирана е класификација C. 
Табела 8: Потрошувачка на енергија за греење со класификација во енергетски сертификат (во првата година на користење на обновената зграда)

\begin{tabular}{|c|c|l|}
\hline $\begin{array}{l}\text { Станбена зграда } \\
\text { Соланова, Унгарија }\end{array}$ & $\begin{array}{l}\text { Станбена зграда на ул. } \\
\text { Макарт, Австрија }\end{array}$ & $\begin{array}{l}\text { Станбена зграда на ул. } \\
\text { Лазар ПопТрајков - } \\
\text { Автокоманда, } \\
\text { Македонија }\end{array}$ \\
\hline $40 \mathrm{kWh} / \mathrm{m}^{2}$ & $17 \mathrm{kWh} / \mathrm{M}^{2}$ & $\begin{array}{l}\text { Температурата во } \\
\text { становите е зголемена } \\
\text { за }+4^{\circ} \mathrm{C} \text { (се отварат } \\
\text { прозорци) }\end{array}$ \\
\hline B & A & \\
\hline
\end{tabular}

Извор:Катерина Петрушевска според податоци од Хазука (Hazucha 2010); APX+MOP (ARCH+MORE 2007); Хабитат(Habitat 2013)

Табела 9: Потрошувачка на енергија за греење со класификација во енергетски сертификат (во втората година на користење на обновената зграда)

\begin{tabular}{|c|c|l|}
\hline $\begin{array}{l}\text { Станбена зграда } \\
\text { Соланова, Унгарија }\end{array}$ & $\begin{array}{l}\text { Станбена зграда на ул. } \\
\text { Макарт, Австрија }\end{array}$ & $\begin{array}{l}\text { Станбена зграда на ул. } \\
\text { Лазар ПопТрајков - } \\
\text { Автокоманда, } \\
\text { Македонија }\end{array}$ \\
\hline $29 \mathrm{kWh} / \mathrm{M}^{2}$ & $14,4 \mathrm{kWh} / \mathrm{M}^{2}$ & $\begin{array}{l}\text { Температурата во } \\
\text { становите е зголемена } \\
\text { за }+4^{\circ} \mathrm{C} \text { (се отварат } \\
\text { прозорци) }\end{array}$ \\
\hline B & A+ & \\
\hline
\end{tabular}

Извор:Катерина Петрушевска според податоци од Хазука (Hazucha 2010); APX+MOP

(ARCH+MORE 2007); Хабитат (Habitat 2013)

\section{5 Забележани обнови во Општина Карпош}

Општина Карпош (Јануари 2012) на седница на совет донесе Правилник за мерките за енергетска ефикасност кои треба да ги исполнат проектите за изградба на нови и реконструкција на постоечки објекти, како услов за добивање на одобрение за градење. На неделата на енергетска ефикасност, 
Хабитат (Habitat 2013) изјавува за планирана енергетско ефикасна реконструкција на 160 станбени згради во Општина Карпош - Скопје.

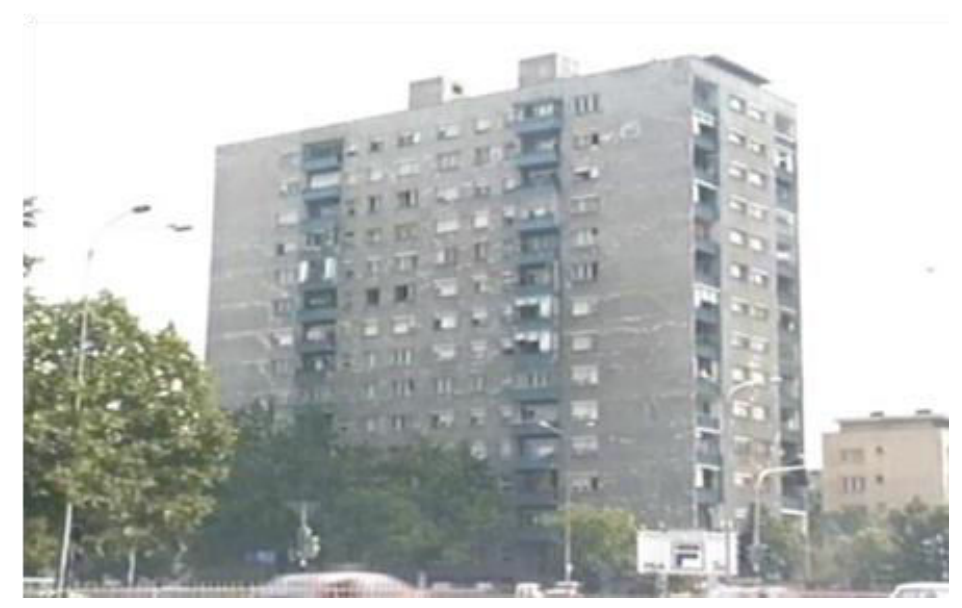

Фигура 51: Станбена заграда на ул. Октомвриска Револуција бр.10 населба Карпош - Скопје (пред реконструкција) Извор: Катерина Петрушевска

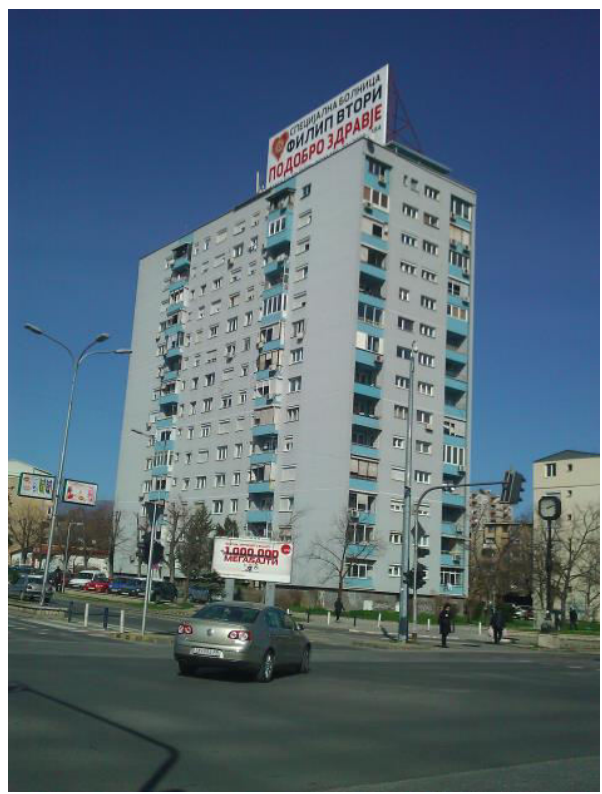

Фигура 52: Станбена заграда на ул. Октомвриска Револуција бр.10 населба Карпош - Скопе (по реконструкција) Извор: Катерина Петрушевска (2013) 

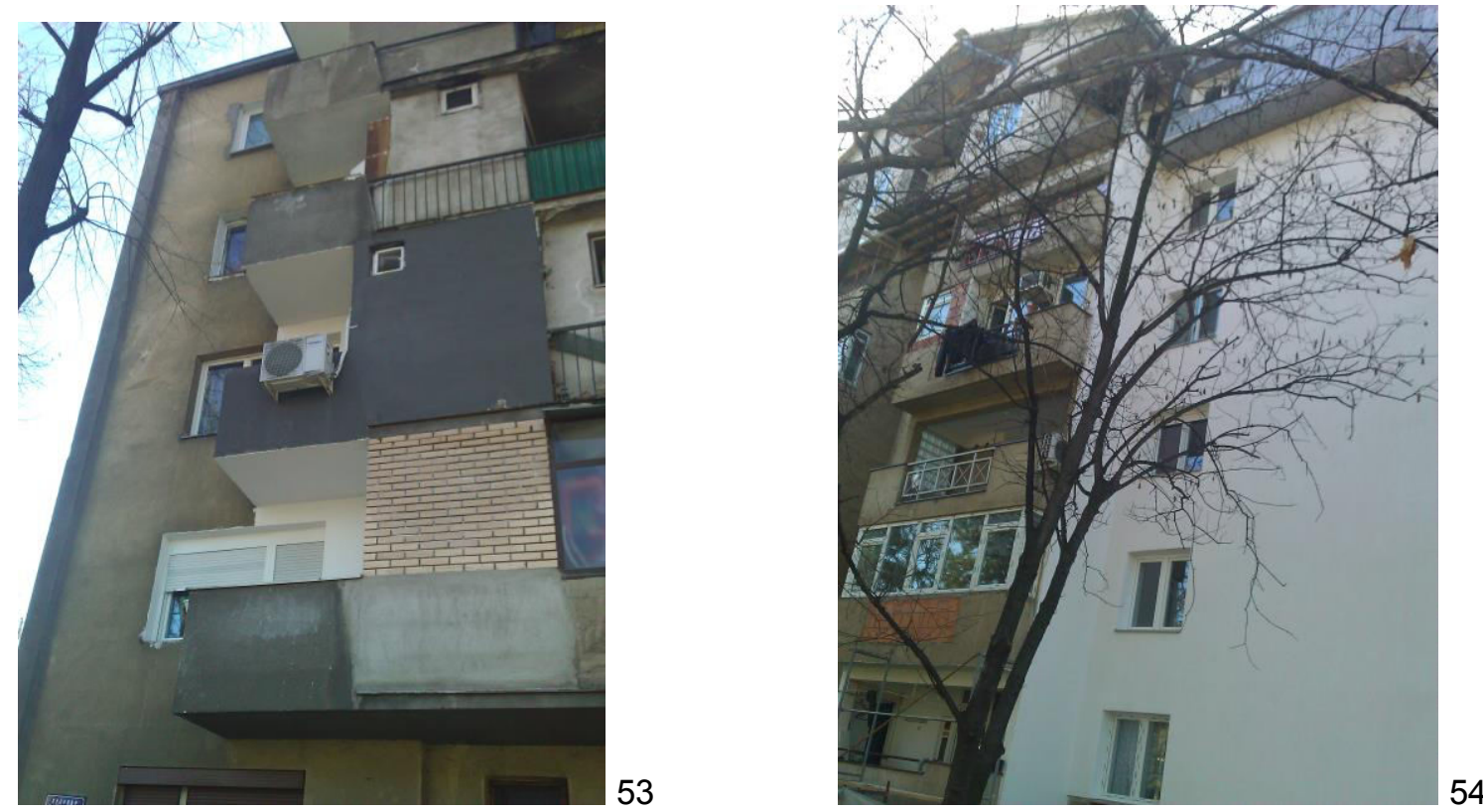

Фигура 53,54 : Примери на реконструкција на територија на Општина Карпош Извор: Катерина Петрушевска (2013)
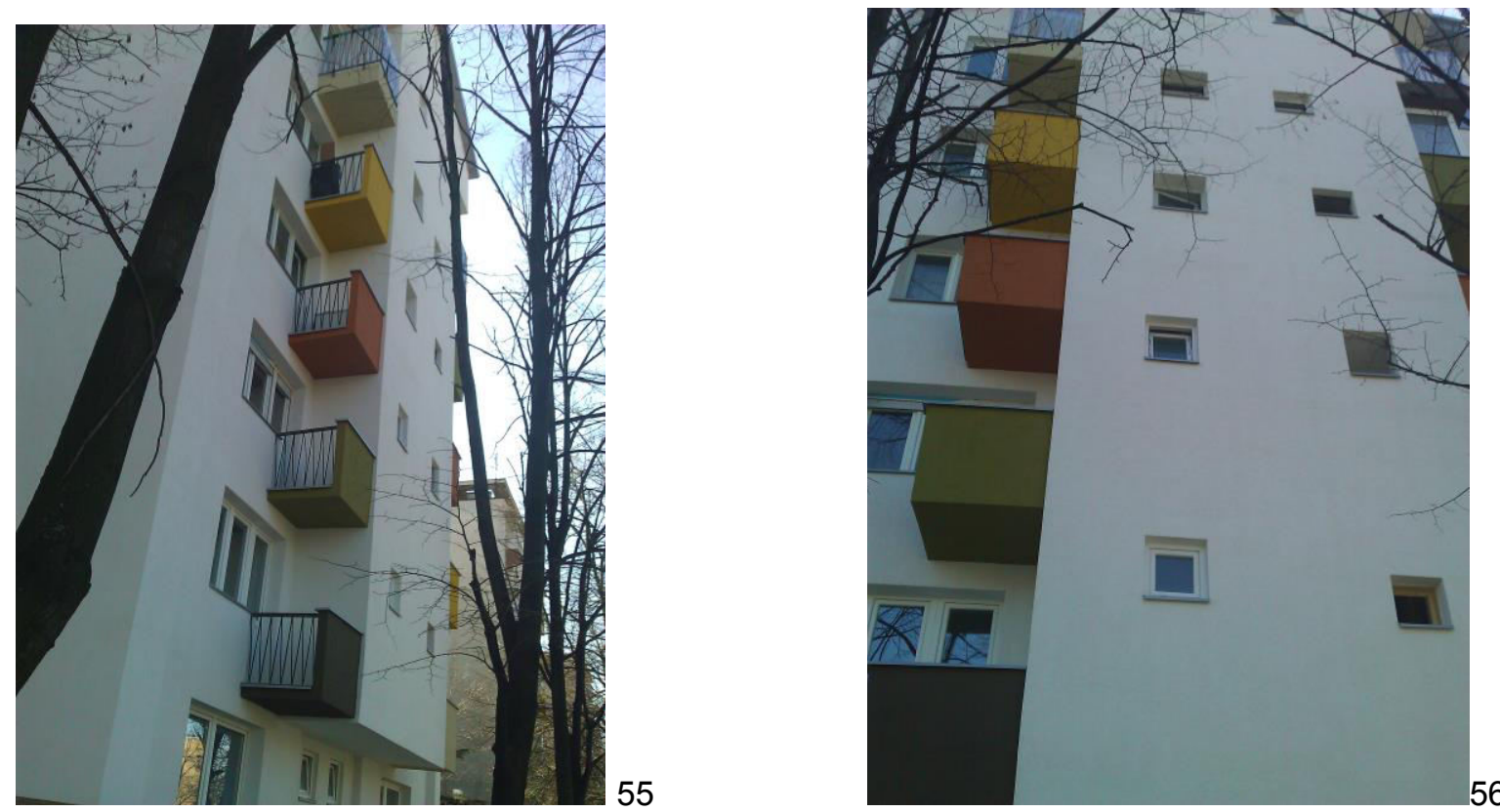

Фигура 55,56: Примери на реконструкција на територија на Општина Карпош Извор: Катерина Петрушевска (2013 

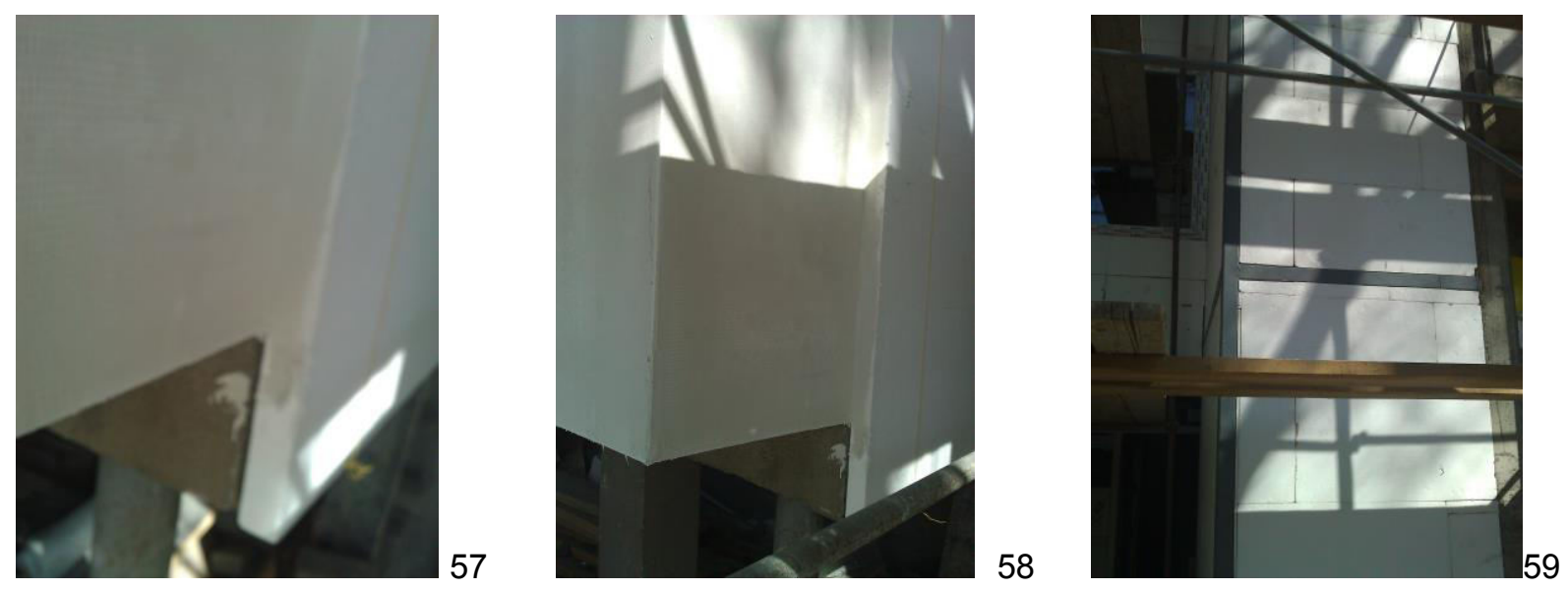

Фигура 57,58,59: Примери на реконструкција на територија на Општина Карпош Извор: Катерина Петрушевска (2013)

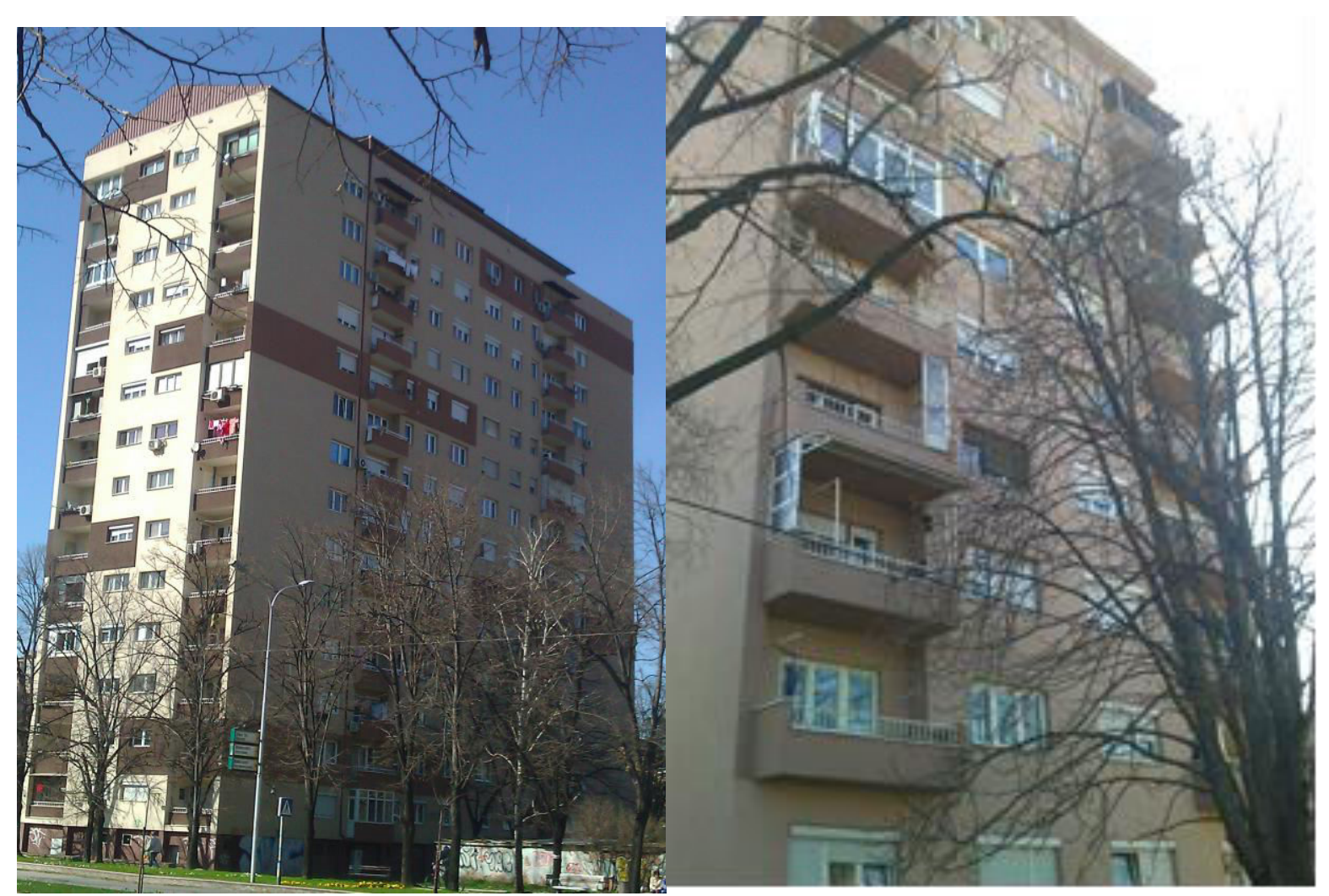

Фигура 60: Примери на реконструкција на територија на Општина Карпош Извор: Катерина Петрушевска (2013) 
7. Приод кон планирана модернизација (обнова), на станбената кула К4, на бул. "Партизански Одреди" бр.76 - Карпош, Скопје со пресметки на потрошувачката на енергија за греење

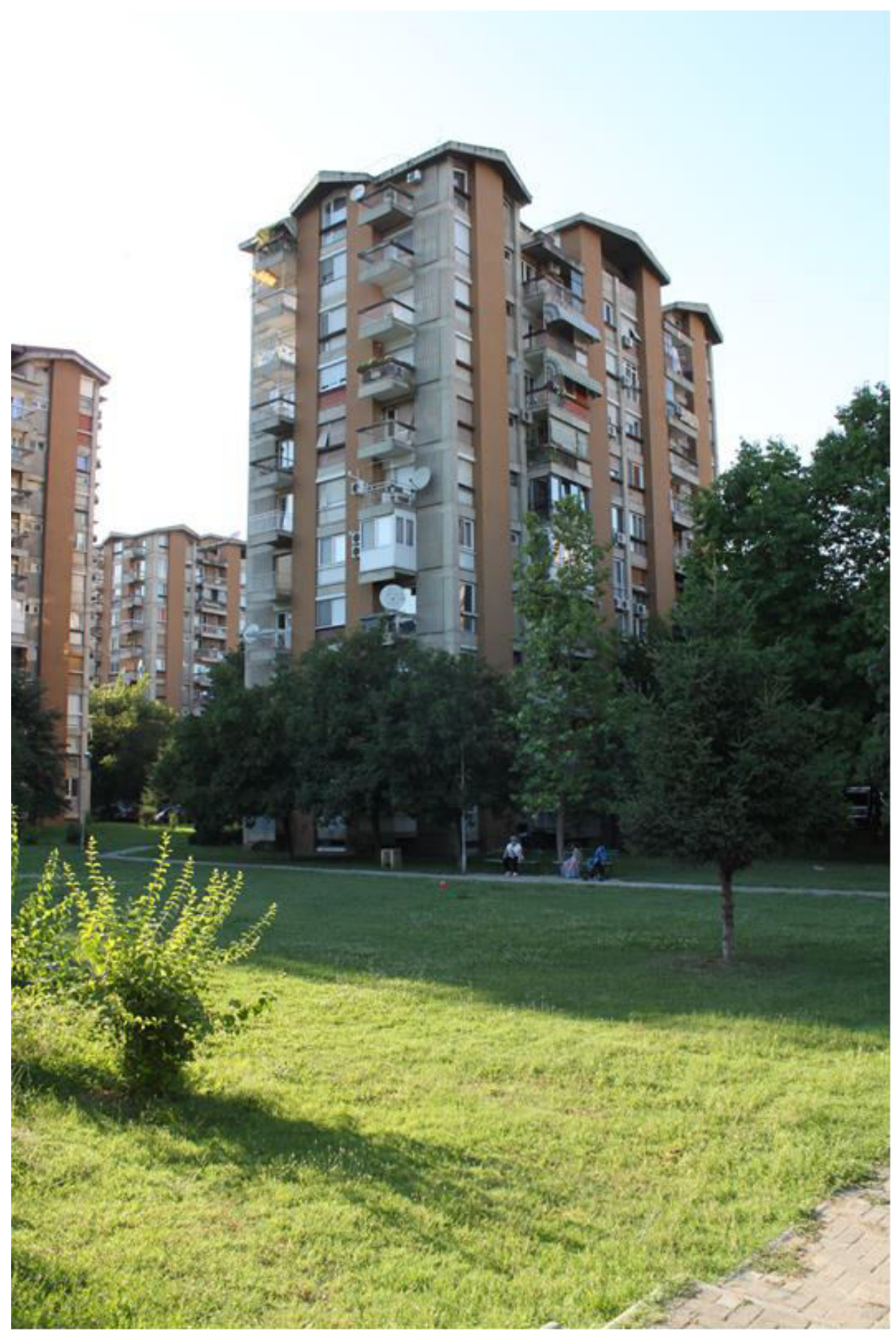

Фигура 61: Постоечка станбена кула во Карпош4 на бул. "Партизански Одреди" бр.76 Извор: Катерина Петрушевска 
7.1 Постоечка состојба - повеќесемејна станбена кула К4 на бул."Партизански Одреди бр.76 "
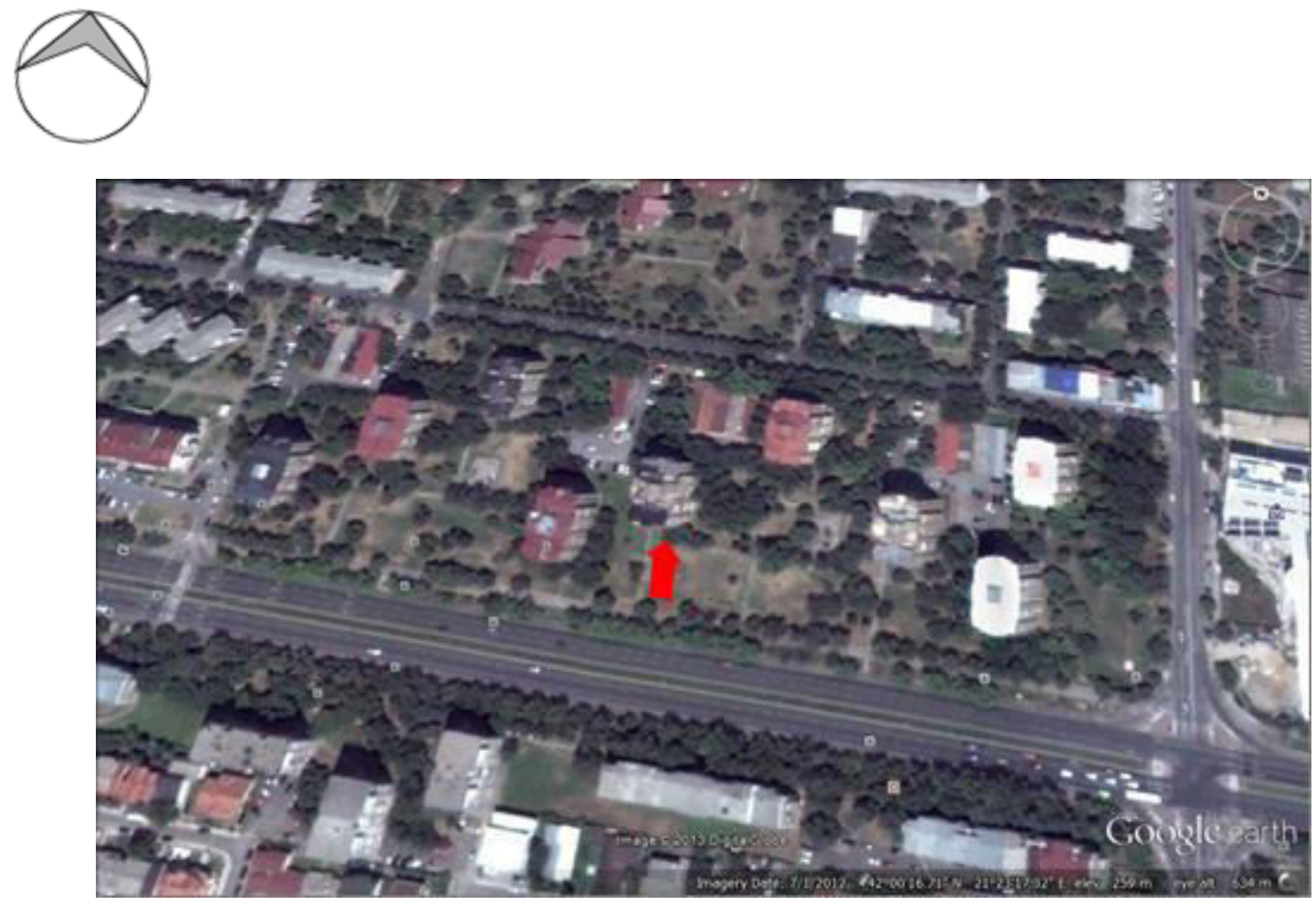

Фигура 62: Ситуација - Станбени кули во Карпош 4

Извор: google earth

Станбениот објект е изграден во почетокот на седумдесетите години од минатиот век, во населбата Карпош 4. Проектиран е во тогашната компанија Пелагонија, проект од арх. Љубица Маленкова.

\section{Локација}

Објектот е лоциран во населбата Карпош 4, со адреса на бул. "Партизански Одреди бр.76." Се работи за слободностоечки станбен објект опкружен со парковски површини кои граничат со улиците "Волгоградска" и бул. "Партизански Одреди" од севрна и јужна страна, како и улица "Љубљанска " од источната страна. Од западната страна во продолжение е лоциран станбено деловен објект "Антико". Од фригура 62, се гледа дека станбените кули на овој урбан потег се поставени со помакнување. На југо западната страна, по дијагонала на растојание од 50м од кулата која е предмет на модернизација во овој труд, постои идентичен објект. На северната страна на растојание од приближно 20-30м се паркинзи и приземни гаражи. На југо источната страна објектот е обиколен со густо зеленило. 


\section{Функционалното решение и ориентација}

Основата развива решение со централно лифртовско - скалишно јадро обиколено со четири станбени единици - фигура 63. Кулата по должина на фасадата е ориентирана исток - запад. Врз база на обсервација на дадената зграда и дополнителни истражувања, во вид на интервју со куќниот совет, со посета и преглед на одредени станбени единици и делови од станбената зграда, утврдено е дека на јужната страна се наоѓаат спални простории кој за време на летниот период се прегреани. Спалните ориентирани на северната страна се во недостаток од топлина и светлина. На западната и источната страна се ориентирани дневните, трпезариите и помошните простории. Западното и јужното сонце во летните периоди предизвикува прегрејување. Објектот по вертикала е со следните содржини: подрум, девет катни висини и поткровје со проодна тераса - (Фигура 64).
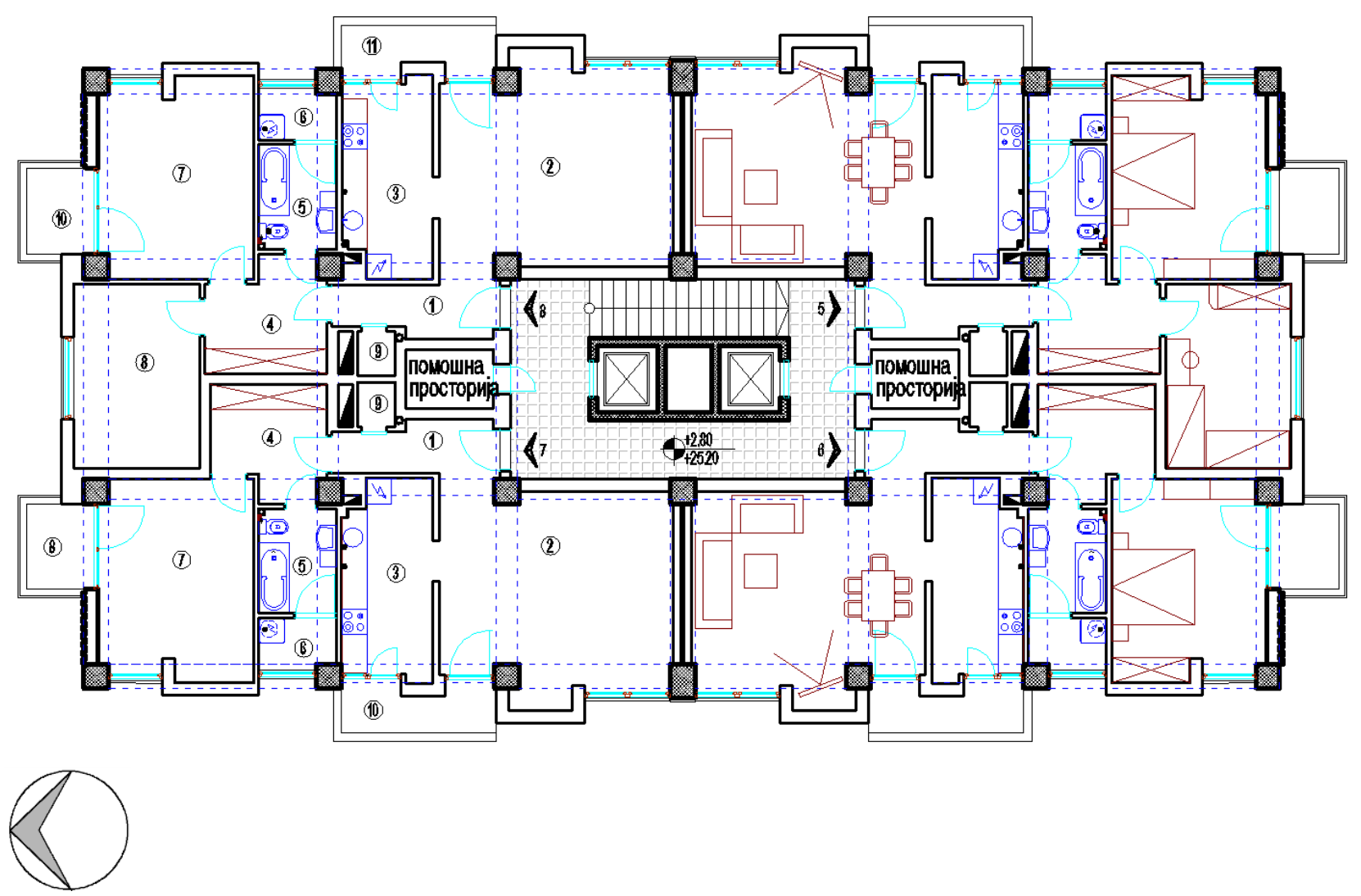

Фигура 63: Основа на карактеристичен кат ( стан бр. 8 / 1, ходник 2, дневна со трпезарија, 3, кујна 4, гардеробер 5, купатило 6, помошна просторија 7, спална соба 8, спална соба, 9, утилити 10, балкон 11, балкон ).

Извор: Катерина Петрушевска 


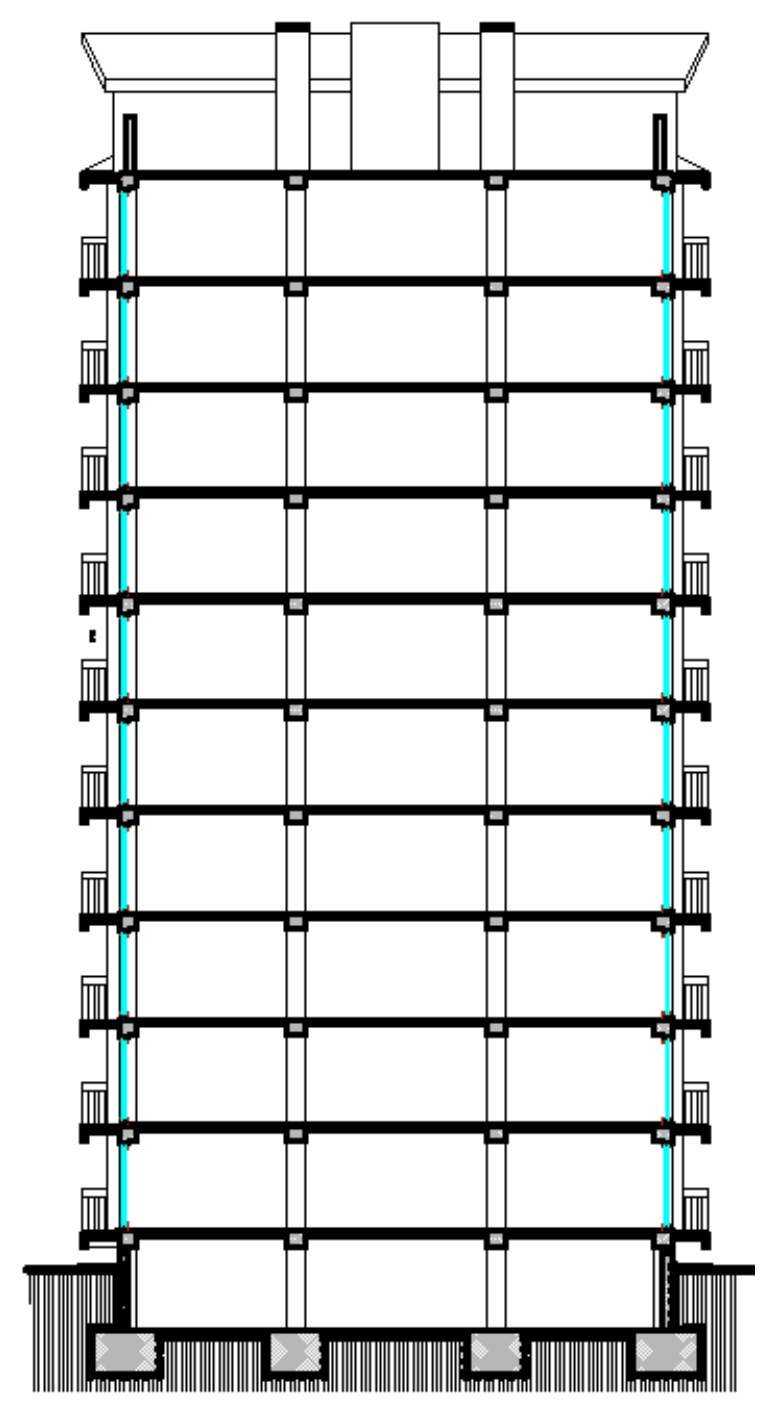

Фигура 64: Пресек 1-1

Извор: Катерина Петрушевска

7.2 Преглед на постоечката состојба на станбената кула К4, на бул. "Партизански Одреди" бр.76, со вклучени методи и техники на истражување

Податоците за оваа студија на случај се потпомогнати од квалитативната метода на истражување од каде се земаат податоци од терен, мерки од лице место и внесување на постоечка состојба во проект. Податоците за постоечките вградени материјали во постоечката градба, се добиени во комуникација со станари, стручни лица, како и со лично истражување врз база на комлетна реконструкција на стан во истата кула. Покрај оваа метода на истражување, во трудот изработена е пресметка на моменталната состојба на потрошувачка на 
енергија за греење. Методата на пресметување е според предлог Правилникот на општина Карпош(2012). Со предлог Правилникот на Општина Карпош (2012) се пропишуваат технички услови за ограничување на годишната потрошувачка на енергија за греење на објектите. "Мерките се однесуваат и за постоечки згради во случај на нивна поголема реконструкција". Правилникот на Општина Карпош (2012:5).

\section{- ПOCTOEЧKA COCTOJБА}

Конструкцијата на објектот е од армирано бетонски плочи, столбови и греди. Спаѓa во редот на објекти кој е изграден после земјотресот каде се промовирани армирано бетонските конструкции. Овие објекти се рангирани како најповолни за обнова по енергетскоефикасни принципи, бидејќи се сметаат за потрошувачи на енергија за греење од $150-300 \mathrm{kWh} / \mathrm{m}^{2} a$ потенцираат Кнежевиќ и Борковиќ (Knezevič и Borkovič 2009:17). Врз основа на обсервација на целиот објект и реконструкција на стан, утврдени се материјалите од кој е изведена зградата. Во понатамошниот текст направена е анализа на состојбата на градежните елементи: кров, рамна проодна тераса, надворешен зид од шуплива тула, надворешен зид од армиранобетонско платно, меѓукатна конструкција над подрум, меѓукатна конструкција помеѓу станови (греани простории), балконска конзола, прозори и врати на фрасада. Покрај увидот на состојбата на градежните елементи и зградата воопшто, изработен е проект на постоечка состојба, претставен во Прилог бр.5. Истиот ќе послужи за подетален увид и пресметка на коефициентите на пренесување на топлина Umax, како и годишната потрошувачка на енергија за греење, претставени во Прилог бр.2. Факторот на фрорма изнесува fo $=\mathrm{A} / \mathrm{Ve}=$ $3215 / 10609=0.30$

Според правилник на ОК(2012):

Фактор на форма на зградата* fo = $\mathrm{A} / \mathrm{Ve}\left(\mathrm{M}^{-1}\right)$ претставува однос помеѓу вкупната површина на обвивката A и греаниот волумен на зградата Vе затворен со обвивката. 


\section{Кров}

Содржината на поткровјето е составена од две раздвоени станбени единици и делумно покриена рамна проодна тераса (фигура 77). Кровот се состои од армирано бетонски коси плочи, премачкани со битумен, кој е оштетен. Низ состаноците на куќниот совет утврдени се проблеми од типот на протекување во становите кој се на поткровјето и деветиот кат, оштетена тераса, недоволно загреан девети кат со големи одливи на топлинска енергија. Донесен е заклучок дека зградата се оштетува од врвот и потребно е решение за заштита од влага и студ. Пресметките за коефициентот за премин на топлина се во табела К1 во Прилог бр.2. Коефициентот на пренесување на топлина $U$ изнесува:

\section{За кров $U=3,67 \mathrm{~W} / \mathrm{M}^{2} \mathrm{~K}>$ од $U \max =0,20 \mathrm{~W} / \mathrm{M}^{2} \mathrm{~K}$}

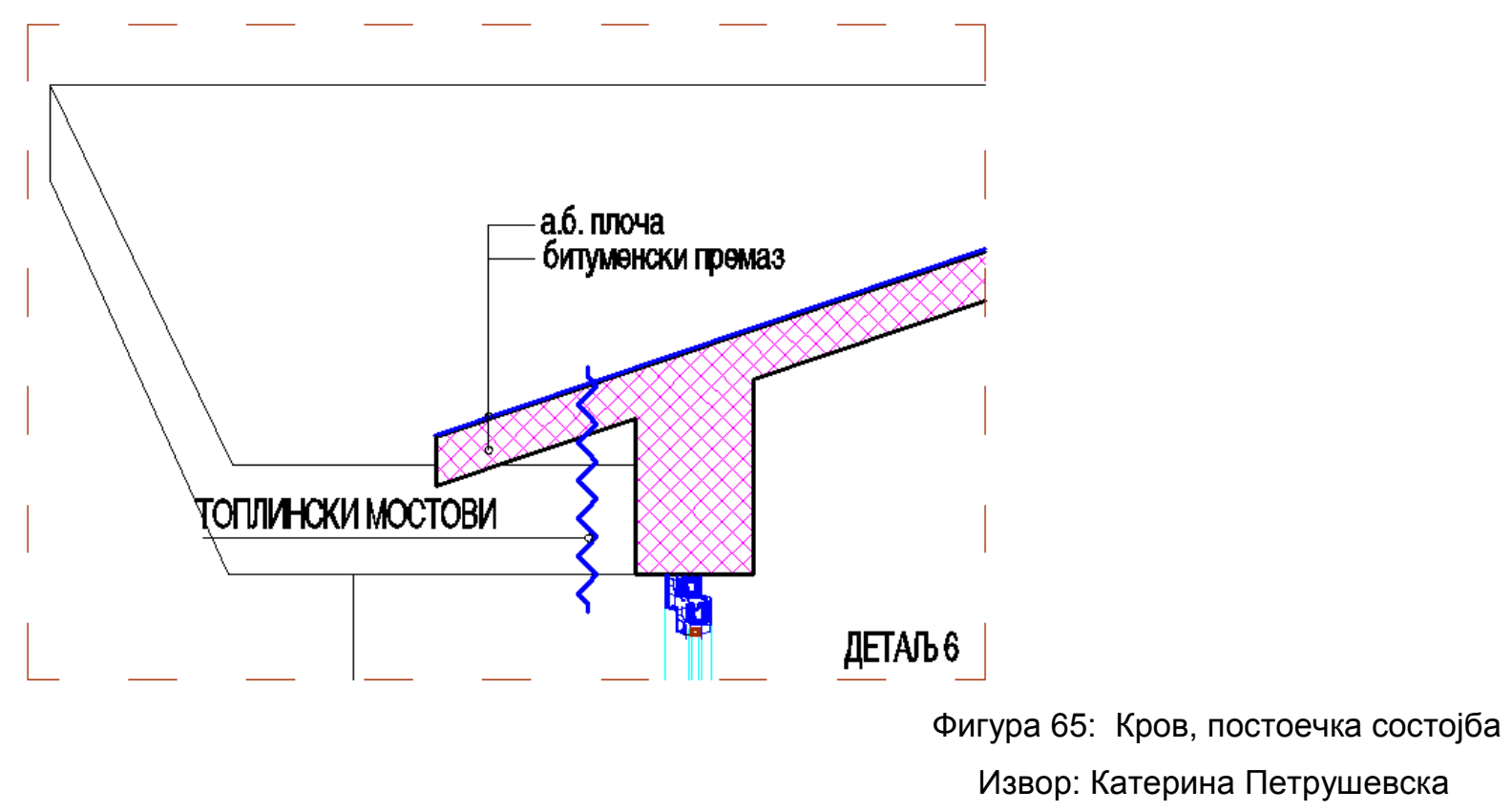

Проодната терасата е делумно покриена, а делумно е отворена и под влијание на атмосферски услови, така што е во лоша состојба. Лицето на подот или завршниот слој е од терацо-бетонски плочи врз подлога од песок, премази од битумен и терхартија, цементен малтер, бетон за пад, парна брана и армиранобетонска конструкција (фигура 66). Пресметките за коефициентот на премин на топлина се во табела Т1 во Прилог бр.2, од каде:

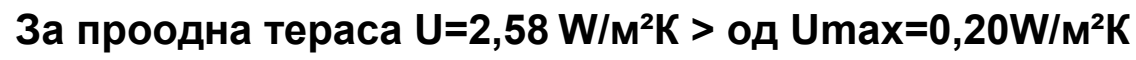

Вредно е да се напомене дека прописите во времето кога е изведуван објектот, не содржат барања за дополнителна термозаштита како денешните. Една од 
причините е и ниската цена на енергијата за греење во тогашните услови на национален стандард.

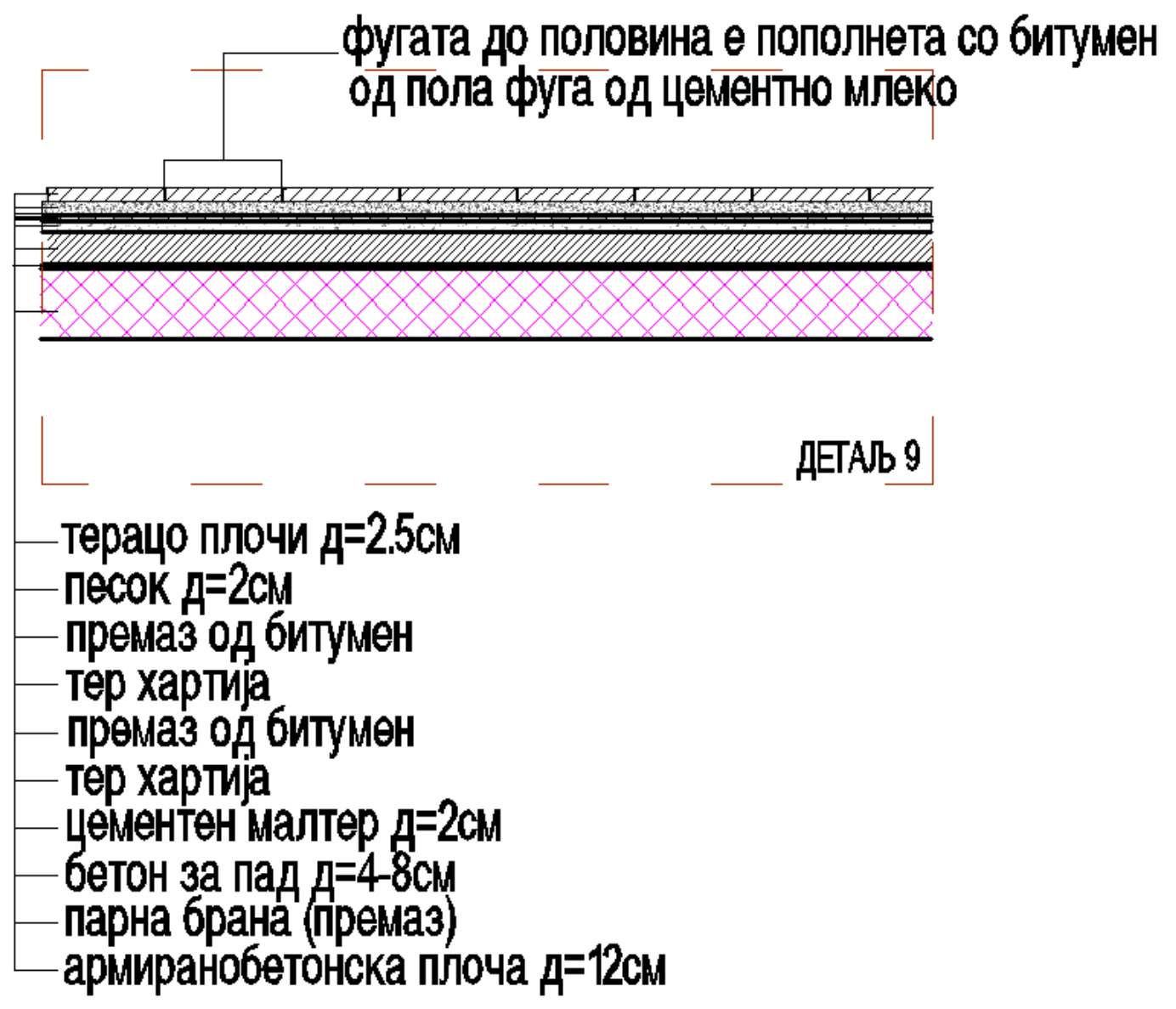

Фигура 66: состав на рамна проодна тераса

Извор:Катерина Петрушевска

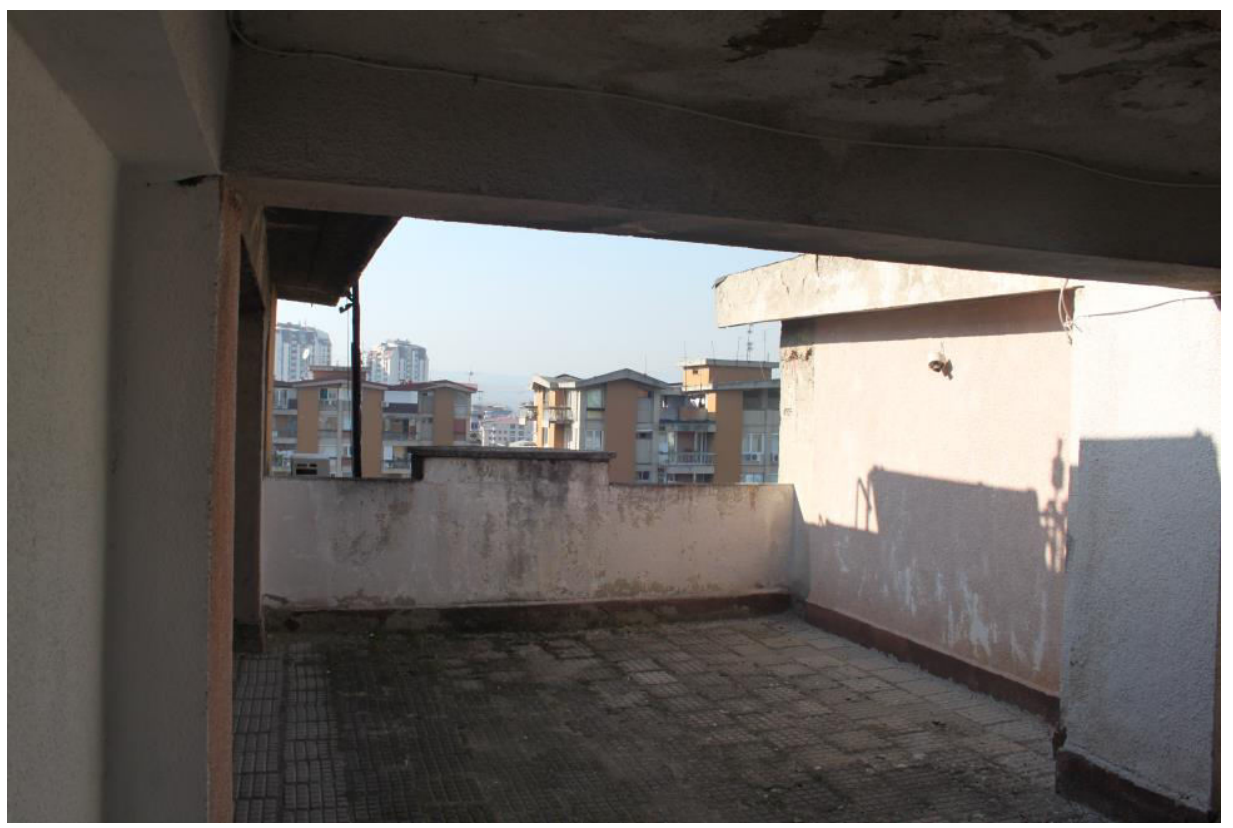

Фигура 67: Состојба на поткровје ( рамна проодна тераса)

Извор:Катерина Петрушевска 


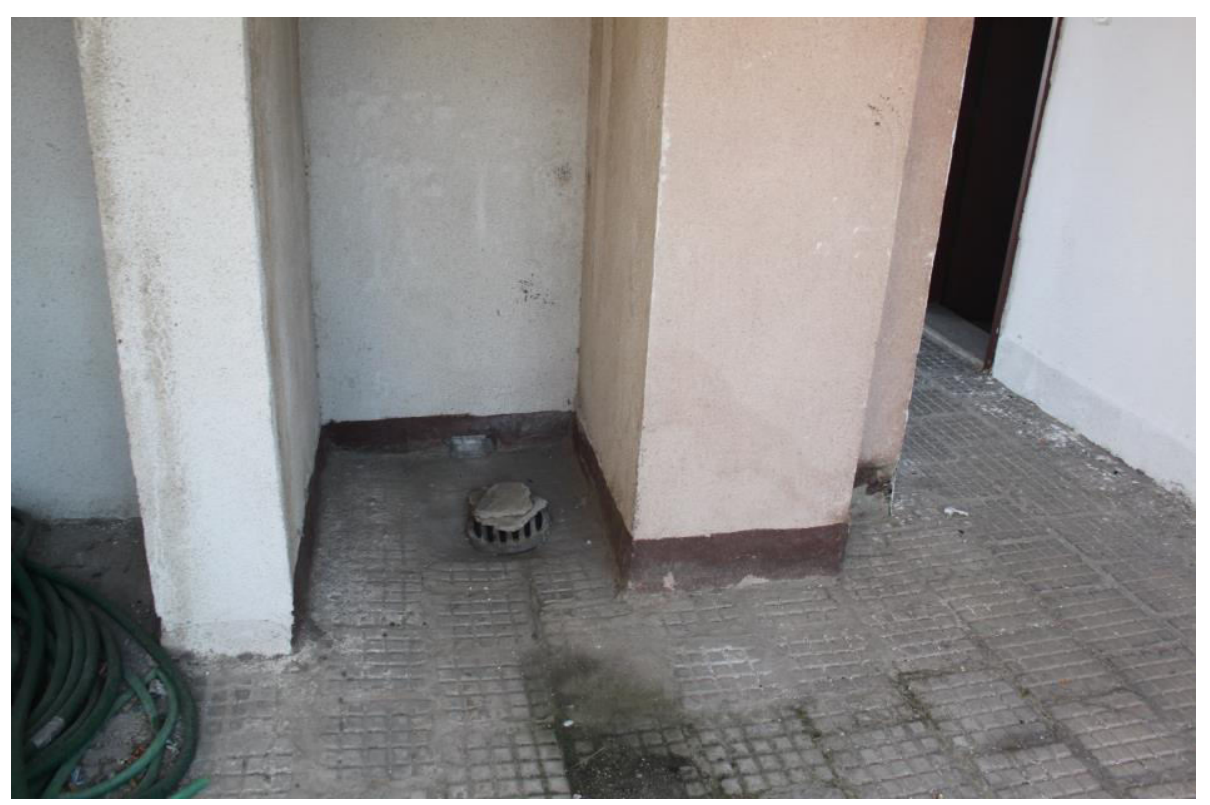

Фигура 68: Рамна тераса - состојба, сливник за атмосфрерска вода Извор: Катерина Петрушевска

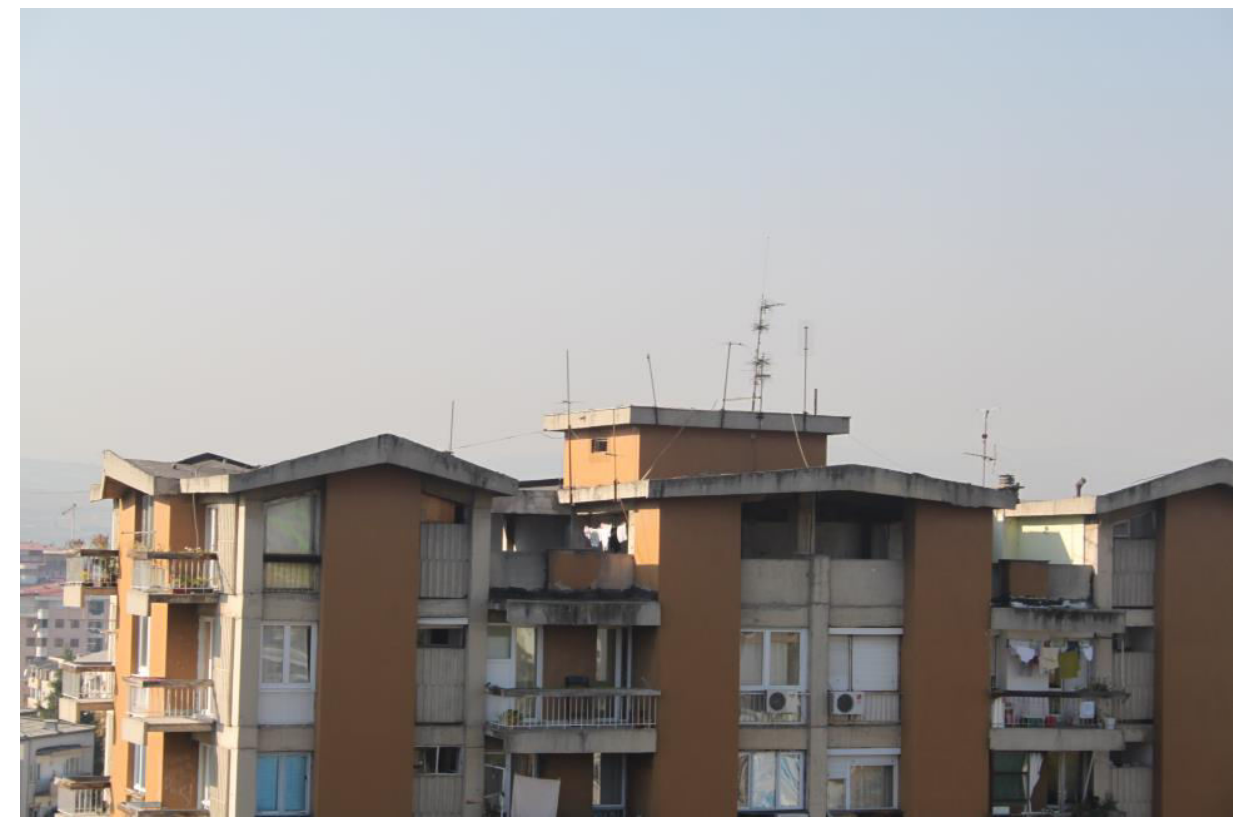

Фигура 69: Постоечка состојба на поткровје (без кровен покривач) Извор: Катерина Петрушевска 


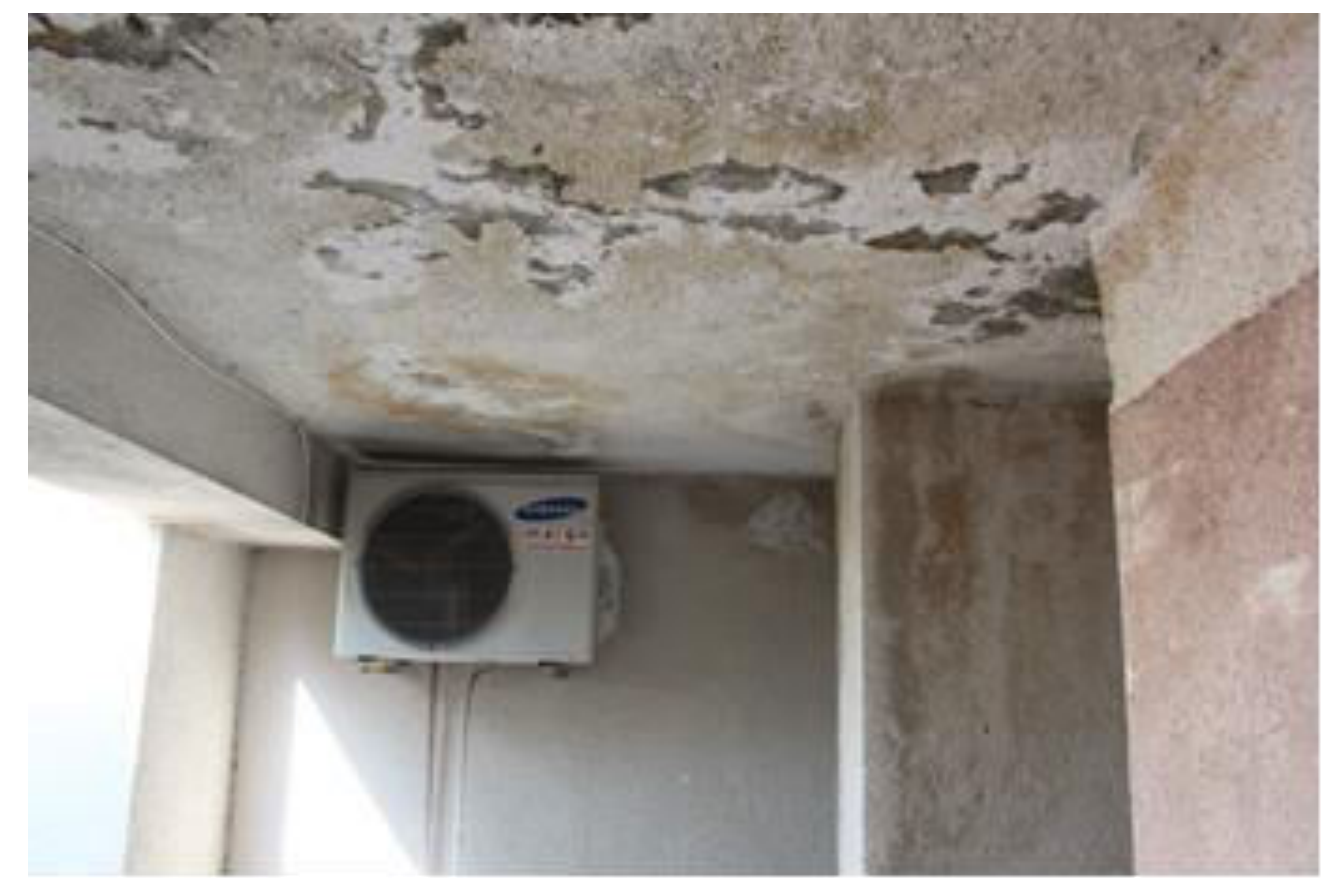

Фигура 70: Состојба на поткровје ( покриена рамна тераса )

Извор:Катерина Петрушевска
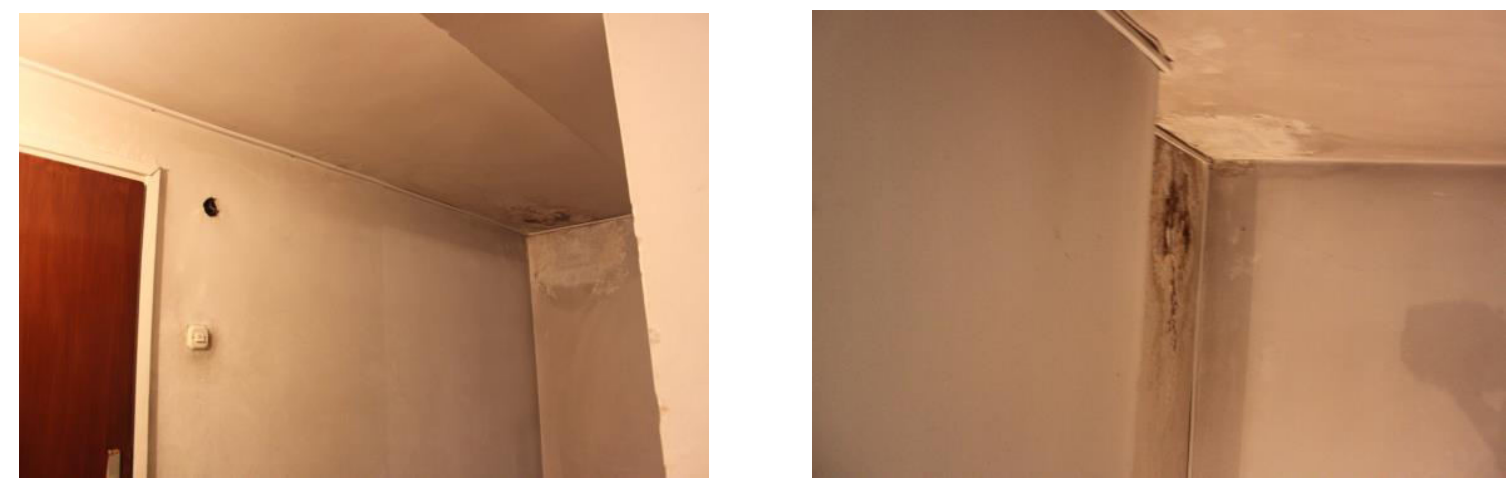

Фигура 71: Состојба на зидови кај влез на деветиот кат

(појава на мувла- синдром на болна зграда )

Извор: Катерина Петрушевска

\section{Надворешни зидови}

Sидовите се изведени со шуплива блок тула со д= $25 \mathrm{~cm}$. Истите се обложени единствено со надворешен и внатрешен малтер. Фасадната облога делумно е благороден малтер, а оставени се и натур армирано-бетонски платна на сегменти од фасадата. Надворешниот sид кој е формиран од ќерамички блок е со коефициент на пренесување на топлина $U=1,55 \mathrm{~W} / \mathrm{M}^{2} \mathrm{~K}$, додека армиранобетонскиот е со коефициент $U=3,43 \mathrm{~W} / \mathrm{M}^{2} \mathrm{~K}$. Овие податоци не ги задоволуваат локалните усвоени коефициенти за пренесување на топлина Umax од Правилникот на Општина Карпош (2012) како и од националниот Правилник 
(2013). Максмалниот дозволен коефициент за пренесување на топлина кај надворешни зидови изнесува 0,35 W/M²K.

Пресметката на $U$ коефициентот на пренесување на топлина, за надворешен sид, преку пример може да се види во табела бр. 10; и фигура 72.

Табела 10: HS1 (од Прилог бр.2)

\begin{tabular}{|l|l|l|l|l|}
\hline p.бр & $\begin{array}{l}\text { Вид на } \\
\text { конструкција }\end{array}$ & $\begin{array}{l}\text { Дебелина } \\
\mathrm{d}=(\mathrm{m})\end{array}$ & $\begin{array}{l}\text { Коесициент на } \\
\text { проводливост } \\
\Lambda=[(\mathrm{W} / \mathrm{mK})]\end{array}$ & $\begin{array}{l}\text { Термички } \\
\text { отпор } \\
\mathrm{R}=\mathrm{d} / \Lambda\left(\mathrm{m}^{2} \mathrm{~K} / \mathrm{W}\right)\end{array}$ \\
\hline 1 & $\begin{array}{l}\text { Благороден } \\
\text { фасаден малтер }\end{array}$ & 0,03 & 0,70 & 0,042 \\
\hline 2 & $\begin{array}{l}\text { Керамички } \\
\text { шуплив блок }\end{array}$ & 0,25 & 0,61 & 0,409 \\
\hline 3 & $\begin{array}{l}\text { Варов малтер } \\
\text { продолжен }\end{array}$ & 0,02 & 0,85 & 0,023 \\
\hline
\end{tabular}

Од табела3.4.1.1(МKC EN ISO 6946/ A1)

Rsi $=0.13$

Rse $=0.04$

Од тука $\mathrm{Rt}=\mathrm{Rsi}+\sum \mathrm{R}+\mathrm{Rse}$

$\mathrm{Rt}=0.13+0.474+0.04=0.63$

$\mathrm{U}=1 / \mathrm{Rt}=1 / 0.644=1.55 \mathrm{~W} / \mathrm{m}^{2} \mathrm{~K}>0,35 \mathrm{~W} / \mathrm{m}^{2} \mathrm{~K}=\mathrm{U}_{\max }$

Од коефициентите на пренесување на топлина низ градежните материјали за станбената зграда К4, кои се прикажани во Табела 11, може да се види дека коефициентот U кај надворешен постоечки sид (Фигура 72 ) изнесува $1.55 \mathrm{~W} / \mathrm{m}^{2} \mathrm{~K}$. Истиот не одговара со денешните услови на усвоени локални и национални коефициенти Umax $=0,35 \mathrm{~W} / \mathrm{m}^{2} \mathrm{~K}$. Градежните фризичари појаснуваат дека колку е помал U коефициентот толку е подобра топлинската заштита на зградата. Од тука се усвоени U вредности за секоја држава, со мах. дозволена топлинска пропусливост за сите делови на градежните конструкции. Но во седумдесетите години кога е изведена зградата, коефициентот на премин на топлина изнесува $1.20 \mathrm{~W} / \mathrm{m}^{2} \mathrm{~K}$ истакнува Николовски (2011). Од тогаш до сега настанатата промена во коефициентите на пренесување на топлина е заради заштеда и 
контрола на енергетскиот систем и потрошувачката на ресурсите кои се повеќе поскапуваат. Овој начин на контрола претставува одржлив развој.

$$
\mathrm{U}=1.55 \mathrm{~W} / \mathrm{m}^{2} \mathrm{~K}>0,35 \mathrm{~W} / \mathrm{m}^{2} \mathrm{~K}=\mathrm{U}_{\max }
$$

(фасаден sид од шуплива блок тула д=25см)

$\mathrm{U}=3,43 \mathrm{~W} / \mathrm{M}^{2} \mathrm{~K}>0,35 \mathrm{~W} / \mathrm{m}^{2} \mathrm{~K}=\mathrm{U}_{\max }$

(фасаден sид армиранобетонско платно д=25см)
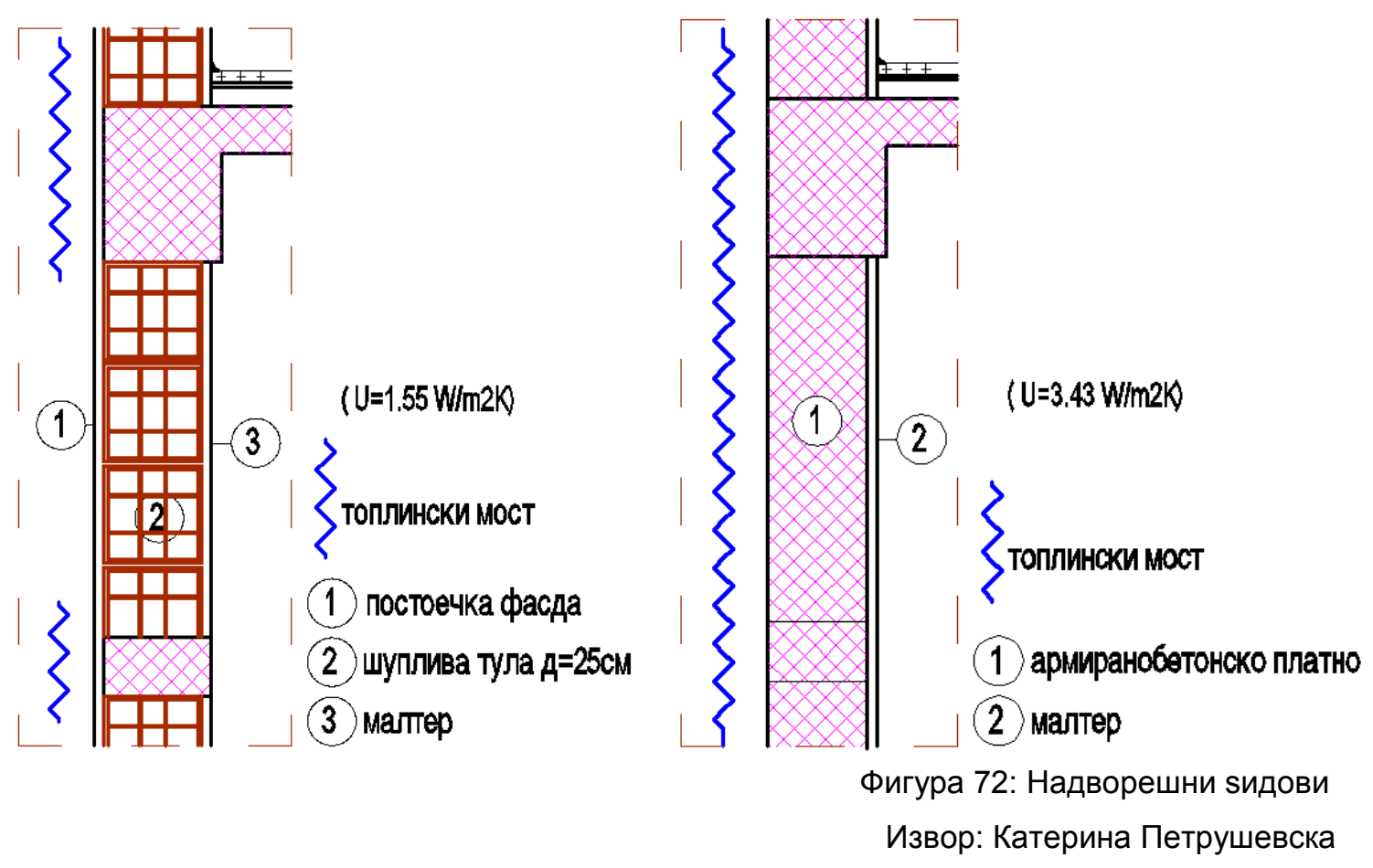

\section{Меѓукатни конструкции-подови}

Плочата која ги дели подрумските простории и приземјето нема топлинска изолација. Истото се случува и низ греаните катови, така што во подлогата во подот не постои материјал за топлинска и звучна изолација. Најкритични се становите кои се наоѓаат на деветиот кат, поготово во делот каде што се покриени само со рамна проодна тераса. Истата не е топлински изолирана во содржината на слојот, така што на делот од кујнските тавани од последниот (девети) кат појавена е мувла. Според Миловановиќ (Milovanovič н.п.) ваква појава е предизвикана заради разликата на температура на дел од градежните конструкции кои се во греани простори, а се граничат со ладни површински температури над негреан простор. Коефициентот на премин на топлина во 
делот од приземје-подрум, добиен од пресметките според Правилникот во табела Д1 во Прилог бр.2 изнесува:

$\mathrm{U}=1,96 \mathrm{~W} / \mathbf{M}^{2} \mathrm{~K}>\mathrm{Umax}=\mathbf{0 , 3 5} \mathrm{W} / \mathbf{M}^{2} \mathrm{~K}$ (кај подна облога од паркет).

$\mathrm{U}=2,37 \mathrm{~W} / \mathbf{M}^{2} \mathrm{~K}>\mathrm{Umax}=\mathbf{0 , 3 5} \mathbf{W} / \mathbf{m}^{2} \mathrm{~K}$ (кај подна облога од керамички плочки).

Овие коефициенти на премин на топлина се однесуваат на делот од меѓукатната конструкција на границата меѓу приземјето и подот.

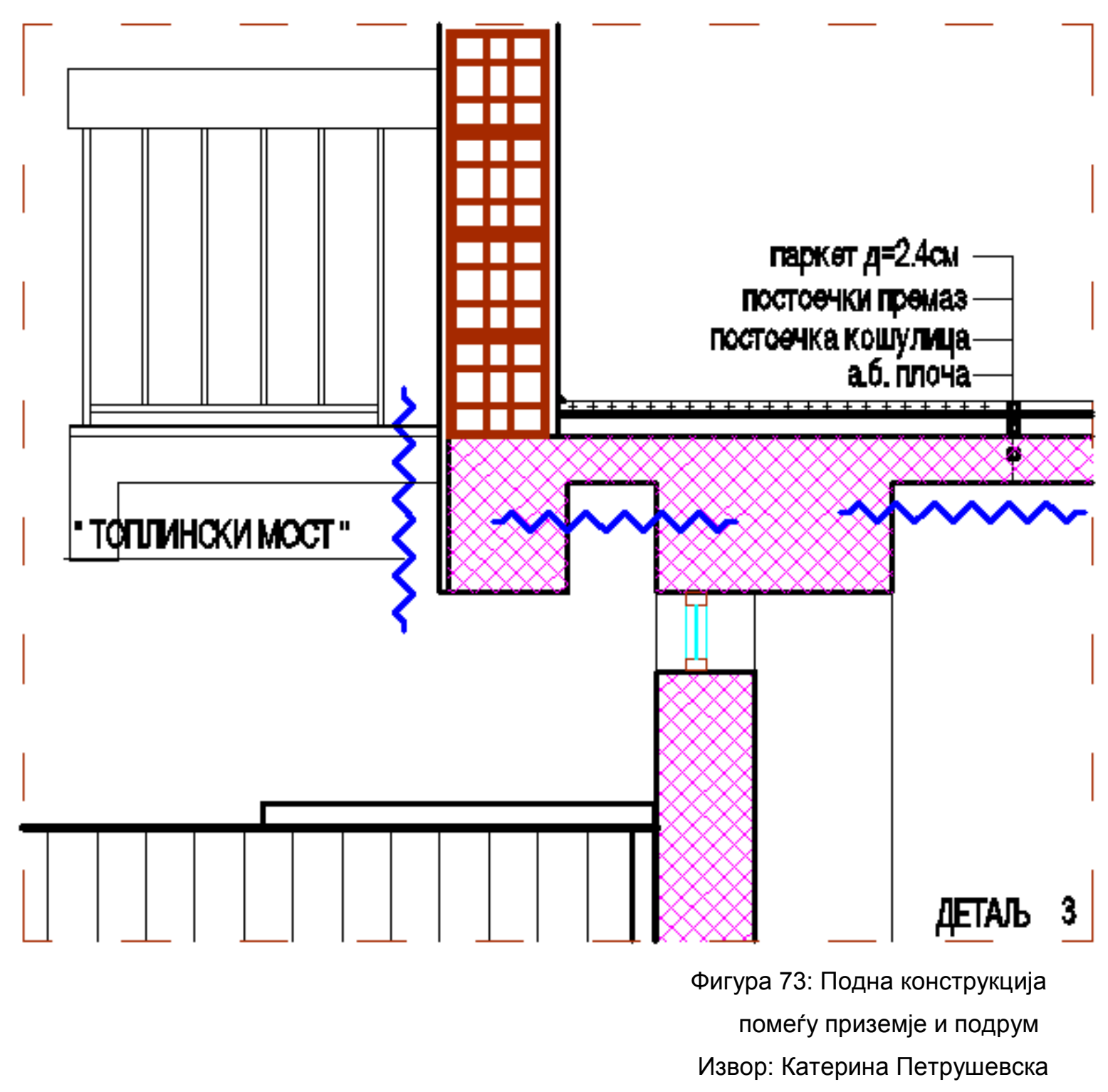

Коефициентот на премин на топлина, на подот низ катовите според пресметките од табела Д4 во Прилог бр.2 изнесува U= 2,87 W/M²K. Максмалниот дозволен коефициент за пренесување на топлина кај меѓукатни конструкции може да се види од табела 11, меѓукатната конструкција меѓу два греани стана е со максимален U коефициент од 1,35 W/M²K. 
$\mathrm{U}=2.87 \mathrm{~W} / \mathbf{M}^{2} \mathrm{~K}>\mathrm{Umax}=1,35 \mathrm{~W} / \mathbf{M}^{2} \mathrm{~K}$ (меѓукатна конструкција над станови)

Може да се заклучи дека постоечките коефициенти на премин на топлина не задоволуваат на барањата за максимално дозволени коефициенти на премин на топлина според локалниот Правилник.

\section{Балкони}

Балконските конзоли се армирано бетонски, поврзани со надворешните конструкции. Предизвикувачи се на топлински мостови. Тие се делови од фасадата каде што се случува зголемена загуба и намалување на внатрешната температура. Претставуваат еден вид рана на обвивката на фасада.

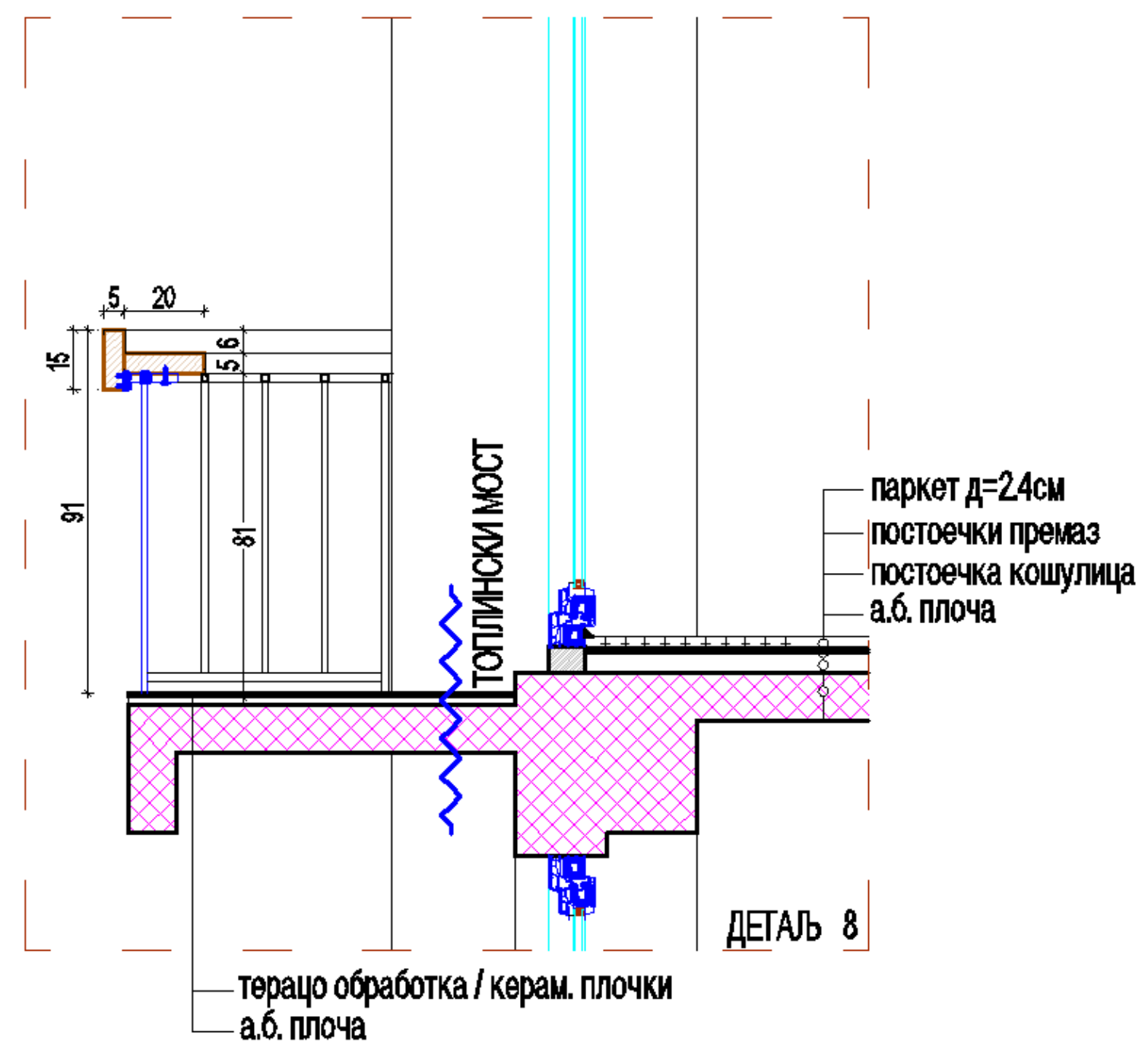

Фигура 74: Балконска конзола Извор: Катерина Петрушевска

Според пресметките за премин на топлина, во табела HS(тм) воПрилог бр. 2 од магистерскиот труд е утврдено дека загубата предизвикана од топлинските 
мостови од балконската конзола изнесува 10-12 \% од обвивката на фасадата. Топлинските мостови кај балконските конзоли, според проектантите за термички инсталации, се третирани како површини кои делуваат на надворешниот зид. Поради тоа добиениот коефициент на премин на топлина $U$ се споредува со максималниот коефициент за надворешен sид кој изнесува Umax $=0,35 \mathrm{~W} / \mathrm{M}^{2} \mathrm{~K}$.

\section{$\mathrm{U}=1 / \mathrm{Rt}=1 / 0,562=1,779 \mathrm{~W} / \mathrm{m}^{2} \mathrm{~K}>\mathrm{Umax}=0,35 \mathrm{~W} / \mathrm{m}^{2} \mathrm{~K}$ (незадоволува)}

Топлотните мостови врз база на геометриски истражувања на фасадата, опфаќаат 10-15\% од вкупната површина на надворешните sидови. Врз основа на тоа може да се пресмета просечен коефициент на премин на топлина за надворешни зидови:

$U_{\text {пр }}=U_{\text {нs }} \times 0,85+U_{\text {ep }} \times 0,15=0,27 \times 0,85+1,77 \times 0,15=0,229+0,265=0,494 \mathrm{~W} / \mathrm{m}^{2} \mathrm{~K}$

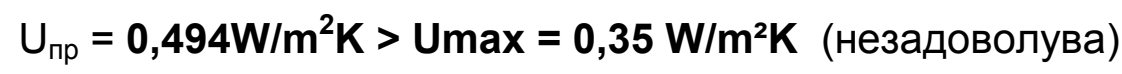

Доколку постои можност при обнова на истата, потребно е да бидат правилно изолирани.

$\bigcup_{\text {пр- просечно }}$

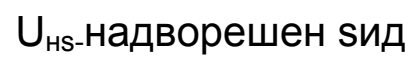

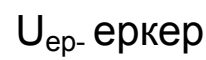

\section{Прозори и врати на фасада}

Прозорците и вратите на фасада се делумно заменети со нови, со ПВЦ рамки, но повеќето се од периодот кога се и вградени. Постоечките се дрвени прозорци и врати, крило на крило. Карактеризирани се со голем процент на загуба на енергија за греење. Обичното стакло брзо ја спроведува топлината кон постудената страна. Загубата на топлотна енергија кај старите прозорци според Башиќ и дp. (Bašič et al. 2008) изнесува 50\%, а истите се вреднуваат со усвоен коефициент $U=3,5 \mathrm{~W} / \mathrm{M}^{2} \mathrm{~K}$. Од голема важност е состојбата меѓу зидот и прозорската рамка. Бидејќи постоечките прозорци се без парапет, дел од паркетот пред прозорецот е потемнет што укажува на влага. При замена на прозорците и вратите на фасада треба да се посвети посебно внимание на вградувањето и монтажата на новите прозори и врати на фасадата. Ова е од голема важност за заптивање и заштита од топлински мостови, како и заштеда на топлински проток. 


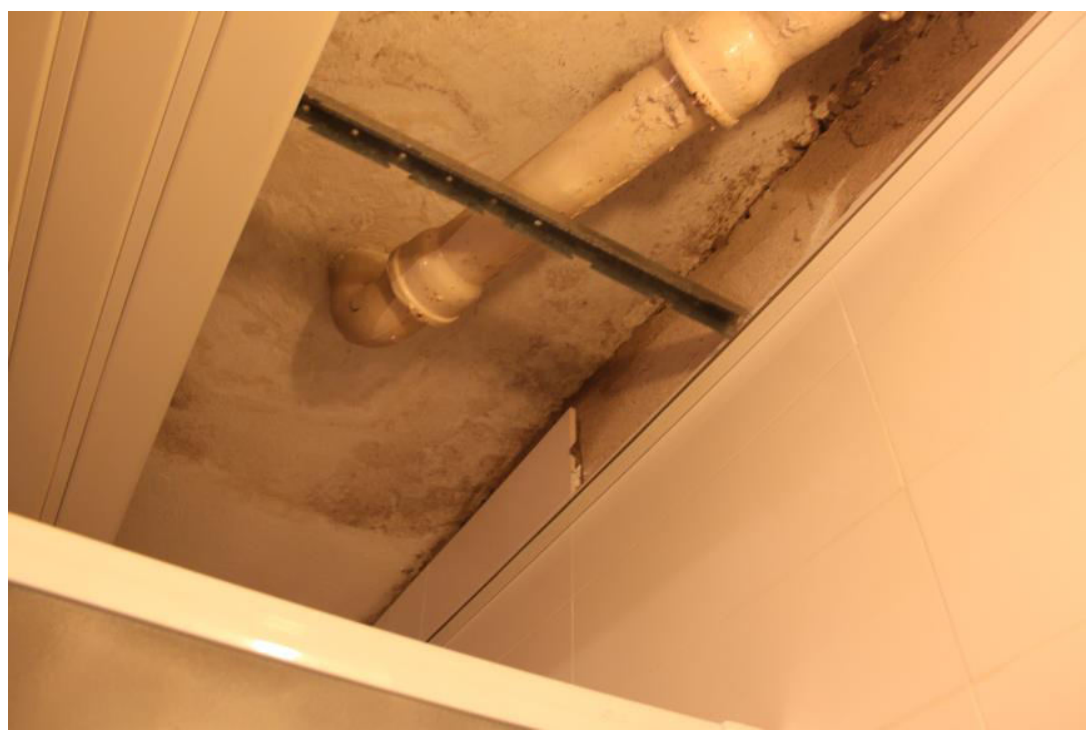

Фигура 75: Состојба на одводни инсталации Извор:Катерина Петрушевска

Од Фигура 67;68;70;71;75, може да се заклучи дека не соодветното одржување на зградата и влагата која низ времето го оштетува објектот дала свој придонес за појава на мувла. Во денешни услови кога би се дало повеќе значај на човековото здравје оваа појава е недозволива. За оваа состојба се виновни повеќе фрактори. Секако тука спаѓаат и крајните корисници. Како што Дарби (Darby 2006) истакнува за потребата од дополнителна едукација на однесувањето на станарите за енергетската ефикасност, така потребата од едукација за добивките од превземени мерки исто е присутна. Со модернизација на објектот со енергетско ефикасни мерки, санација, реконструкција и правилно одржување се заштитува објектот од влага и мувла, а добива и заштеда на топлотна енергија. Треба да се истакне дека стандардите и коефициентите за премин на топлина во 1972г. (кога е градена станбената зграда) не одговараат со денешните барања и пропишани правилници за енергетски карактеристики на згради. Николовски (2011) потенцира дека за оваа проблематика постои еволуција како еден вид развој на критериумите на коефициентот на премин на топлина, но тешко се имплементира во последните дваесет години. Хазука (Hazucha 2010) потенцира дека $90 \%$ од зградите во Европа се стари триесетина години и имаат потреба од модернизација. Истите спаѓаат во "D" или "F" категорија кај енергетските сертификати (пасоши). 


\section{Коефициенти на пренесување на топлина низ градежните материјали}

Во Табелата бр.11 прикажани се коефициенти за премин на топлина низ градежните елементи од зградата: надворешен sид од шуплива тула, надворешен зид од армиранобетонско платно, меѓукатна конструкција над подрум, меѓукатна конструкција помеѓу станови (греани простории), внатрешни sидови кој претставуваат граница меѓу скалишно јадро и станбени единици, проодна тераса, кров и тн. Пресметките се внесени од сумирањето на коефициентите и компарацијата со максимално дозволените од табела U/Umax:, во Прилог бр.2 од Магистерскиот труд. Коефициентот на премин на топлина добиен од елаборатот од Прилог бр.2 не ги исполнува барањата за максимално добиените коефициенти од Прилог бр.4.

Табела 11: Коефициенти на пренесување на топлина низ градежните материјали

\begin{tabular}{|c|c|c|c|c|c|}
\hline р.бр & ПОЛОЖБА & ознака & $\begin{array}{c}\mathbf{U} \\
{\left[\left(\mathrm{W} / \mathrm{m}^{2} \mathrm{~K}\right)\right]}\end{array}$ & $\begin{array}{c}\mathrm{U}_{\max } \\
{\left[\left(\mathrm{W} / \mathrm{m}^{2} \mathrm{~K}\right)\right]}\end{array}$ & $\begin{array}{c}\text { Исполенето } \\
\text { ДА / НЕ }\end{array}$ \\
\hline 1 & Надворешен sид - фрасада & HS1 & 1,55 & 0,35 & $\mathrm{HE}$ \\
\hline 2 & $\begin{array}{l}\text { Надворешен зид - фасаден } \\
\text { - АБ платно }\end{array}$ & HS2 & 3,43 & 0,35 & $\mathrm{HE}$ \\
\hline 3 & $\begin{array}{l}\text { Под (паркет - над негреан } \\
\text { подрум) }\end{array}$ & Д1 & 1,96 & 0,35 & $\mathrm{HE}$ \\
\hline 4 & $\begin{array}{l}\text { Под (плочки - над негреан } \\
\text { подрум) }\end{array}$ & Д2 & 2,37 & 0,35 & $\mathrm{HE}$ \\
\hline 5 & $\begin{array}{l}\text { Топлотен мост кај } \\
\text { балконска конзола } \\
\text { ( површински) }\end{array}$ & HS(т.м.) & 0,49 & 0,35 & $\mathrm{HE}$ \\
\hline 6 & Под - под во соба на кат & Д4 & 2,87 & 1,35 & $\mathrm{HE}$ \\
\hline 7 & $\begin{array}{l}\text { Внатрешен преграден sид - } \\
\text { стан - скалишен простор }\end{array}$ & BS1 & 1,41 & 0,35 & $\mathrm{HE}$ \\
\hline 8 & Проодна тераса & T1 & 2,58 & 0,20 & $\mathrm{HE}$ \\
\hline 9 & Кров & K1 & 3,67 & 0,20 & $\mathrm{HE}$ \\
\hline
\end{tabular}

Извор: Катерина Петрушевска 
Овие U коефициенти се добиени со пресметка на:

Топлински отпор $\mathrm{R}$

Површински отпор Rs

Сумата на топлински отпори $\mathrm{R}$ T $=\mathrm{Rsi}+\sum \mathrm{R}+\mathrm{Rse}$

Податокот за овие коефициенти е пресметан во елаборатот за енергетска ефикасност, според предлог Правилникот на О.К. (2012), а се претсавени во Прилог бр.2 од Магистерскиот труд.

Целта на оваа методологија во правилникот на О.К. (2012) е според градежнофризички пресметки да се покаже потрошувачката на енергија за греење и се задоволат барањата со овој предлог Правилник. Пресметките се однесуваат на:

-Коефрициенти на пренесување на топлина $U$ за секоја градежна конструкција, споредени со Umax вредностите.

-Коефициент на специфични топлински загуби со трансмисија Н'т на целиот објект.

Методологијата по која е добиена пресметката ги вклучува следните параметри:

1. Проектни параметри

2. Корисна површина на зградата

3. Обвивка на зградата

4. Нето греан волумен на зградата

5. Бруто греан волумен на зградата

6. Фактор форма на зградата

За да се пресметаат овие наведени параметри, потребно е да постои графички приказ на зградата или проект на постоечка состојба. Во трудот, во Прилог бр. 5 од графичките прилози приложен е проект на постоечка состојба, кој е добиен според мерки од лице место.

\section{Согледување на прегледот од постоечката состојба}

Од разгледувањата на постоечката состојба на објектот К4, констатирано е дека најголемите загуби, протекувања, влажнење и влошување на квалитетот на живот е на станбените единици кои се на деветиот кат. Поткровјето е оштетено од влага, но постои можност за санација и затварање до компактна фрактор фрорма во овој дел од објектот. Коефициентите за премин на топлина од 
табела 11 не ги исполнуваат барањата за максимално дозволените коефициенти на премин на топлина. Од тука може да се заклучи дека не доволно изолиран или воопшто неизолираниот објект од термички аспект го чини објектот да има големи одливи на топлина од внатрешна према надворешна средина. Резултатот за постоечката потрошувачка на енергија за греење изнесува 130,76 kWh / m²a - (киловат-часови на еден метар квадратен потрошувачка на енергија за греење на годишно ниво). Овасе однесува на трансмисионите загуби, но не и на вентилационите. Пресметките се според Правилникот на Општина Карпош (2012), истите се комплетно приложени во Прилог бр.2 од магистерскиот труд. Со дадената потрошувачка на топлотна енергија се воочува дека зградата спаѓа во групата на енергетско - неефикасни објекти. Кога би се класифицирале во енергетски пасоши би добиле рејтинг "D". Ова означување на објектите може да се види во фригура 3, каде потрошувачката се однесува на станбени објекти кои трошат $\leq 150 \mathrm{kWh} / \mathrm{m}^{2} \mathbf{a}$. Бидејќи за оваа проблематика се судираме со недостаток од литература, потребно е за секој објект да се изврши енергетски и градежен преглед на состојбата, па по изнесените и сумирани резултати да се отпочне со идејата за модернизирање. 


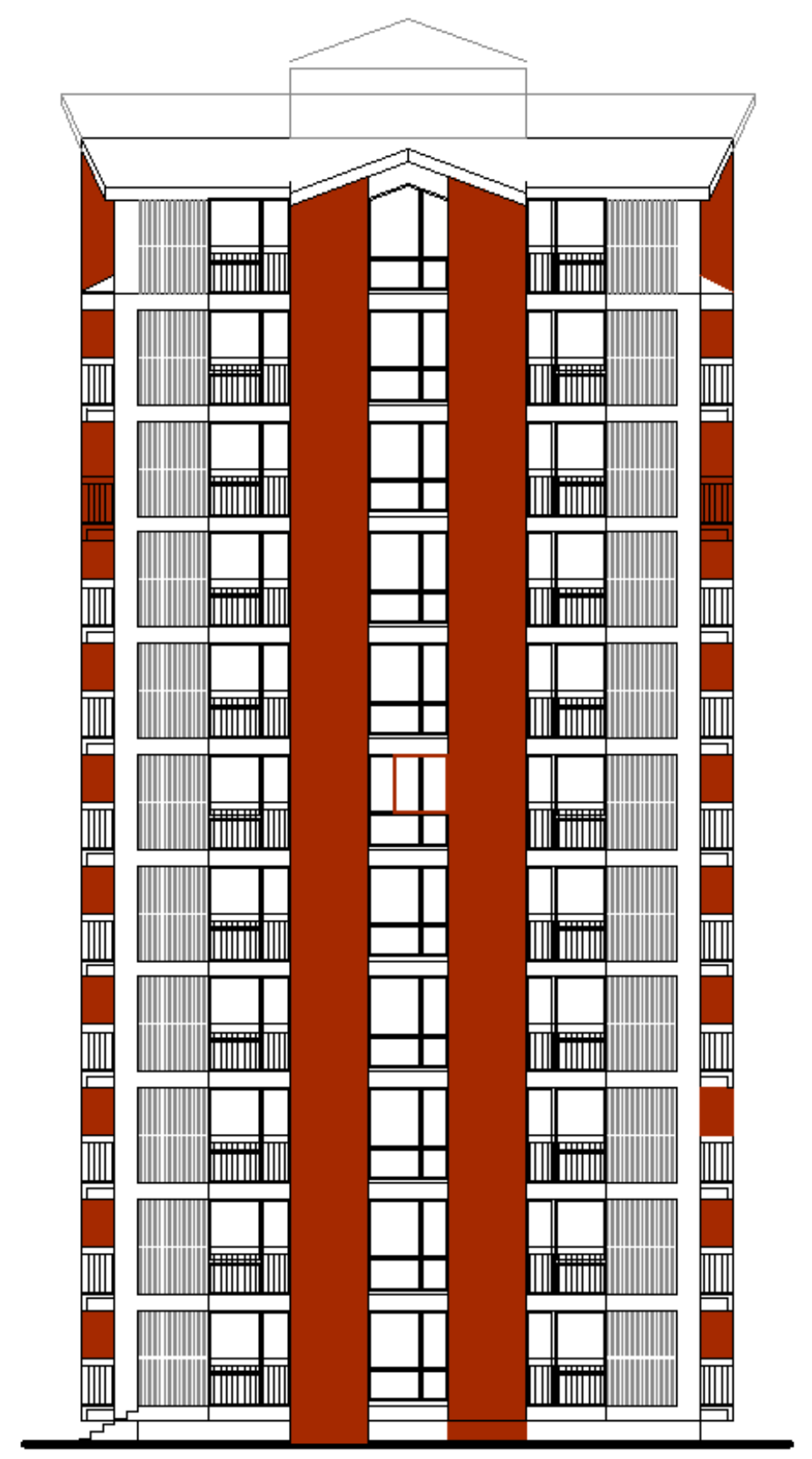

ФACAQHA BOAA:

армирано бетонска конструкција

благороден фасаден малтер теракота

Фигура 76: Фасада југ постоечка состојба Извор: Катерина Петрушевска 


\section{3 Предложени мерки за обновена состојба}

По извршената пресметка на потрошувачка на енергија за греење на постоечката состојба, претставена во Прилог бр.2 од трудот и увидот на истата, направен е проект за санација на кров, со предлог за проширување на станбените простории на поткровјето и реконструкција на обвивката на зградата на ул. Партизански Одреди бр.76. Во графичките прилози, кои се претставени во новопроектирана состојба во Прилог бр.5 од трудот, всушност претставен е предлог проект за обнова на кулата - К4. Во истиот се вградени повеќе енергетско ефикасни мерки. Со добиените резултати од пресметките во Прилог бр.3, се интегрира избрана изолација со соодветни коефициенти за премин на топлина $U$ на секој градежен материјал. Потоа добиваме точна претстава за заштедата на одлив на енергија со вградување на топлинска изолација со точно пресметана дебелина на слојот. Во проектот од новопроектираната состојба, во Прилог бр.5 од трудот е приложен предлог на проект со превземени неколку важни промени и мерки. Мерките се разгледувани по препораките на Лехнер (Lechner 2013) кој ќе истакне за одговорноста кон трошоците и мерките кои треба да се превземат по принципот на " берење на плодовите кои се прво на дофат на рака." Од тука може да се искористат следните идеи:

\section{- Бојата на објектот.}

Ова подразбира дека светлите бои се потребни, поготово за јужната ориентација бидејќи не ги впиваат сончевите зраци во летниот период како темните фасади и не доведуваат до прегрејување на зидовите.

- Сончеви зраци, заштита и внесување преку отворите.

Би можело да се интервенира со соодветно засенување со елементи пред фрасада или замена на прзорското стакло со соодветни стаклени рефрлектирачки површини на места каде е потребно. Пасивно осончување, или внесување на светилна во зимските денови.

\section{- Соодветна изолација}

Изборот и позиционирањето на изолациониот материјал е во зависност од видот и намената на објектот 
За новопроектираната состојба превземени се одредени мерки во поглед на покривање на поткровје со соодветен кровен покривач, соодветно изолирање на обвивката на зградата, избор на нови и замена на старите фасадни прозори/врати, засенување од јужно и западно сонце, избор на боја на фрасада. Сите превземени мерки влијаат да заштедата на енергија за греење биде $71 \%$. Сите мерки се приложени графички во детали во проект на новопроектираната состојба претставени во Прилог бр.5 на крајот од трудот. Пресметките за потрошувачката или заштедата на енергија на годишно ниво се пресметани во елаборат за енергетска ефикасност претставен во Прилог бр.3. Во понатамошниот текст, обработени се градежните елементи од кои е изведена кулата од аспект на термичка обработка. Се предлага да се редизајнира поткровјето и покрие целосно со нов покривач. Потоа се предлага комплетна санација и обнова на обвивката на зградата. За изборот и одлуката на потребните материјали и димензионирање клучна улога има задоволувањето на максималните коефициенти на премин на топлина. 


\section{- НОВОПРОЕКТИРАНА СОСТОЈБА}

\section{Кров}

На поткровјето, (фигура 77,78 ) даден е предлог за редизајн на станбените простории, како последица од повеќе причини. Низ времето, проодната и делумно покриена тераса над деветиот кат е оштетена, каде предизвикува многу проблеми на становите кои се под истата. Од друга страна покрај влагата, која го оштетува овој дел од објектот, постои потреба и од соодветна термо заштита. Доколку се обнови проодната тераса, би требало да се постави нов слој од термоизолација, парна брана и нови плочи. Но ова решение е неизводливо бидејќи ќе настане проблем со високата денивелација при влегувањето во постоечките станбени единици на поткровјето. Од тука најсоодветно стручно решение се налага со редизајнирање на покривната конструкција како компактна целина, за да под истата се изведат станбени единици соединати со останатите на поткровјето. Со тоа би се решил проблемот со влагата, но и намалување на топлинските загуби. Становите на деветиот кат, наместо проблеми со влага и одлив на енергија би добиле греани простории над нив. Становите кои се на поткровје, од фигура 77 се гледа дека се два кои се разделени со тераса. Со новото решение од фигуура 78 , или додавање на простории до нив, би се добила покомпактна форма од која произлегува меѓусебно загревање, а новата покривна топлотно изолирана конструкција ќе обезбеди задршка на топлина. При интервју со сопствениците на поткровјето дојдено е до можно решение на проблемот со покривањето, од финансиски аспект. Станарите од поткровје би инвестирале во комплетно ново покривање со барање за дел од корисната површина од рамната тераса. Останатиот дел од корисната површина во овој труд се предлага да остане во сопственост на заедницата на станари. Така би добиле едно избалансирано решение, кое секако мора да помине низ гласачко тело. Ова надополнување не предизвикува зголемување на густината на становање, а може да го реши проблемот со собирање на финансиски средства за одржување на зградата со продажба или издавање на новодобиените простории. Во графичките прилози, во проектот кој е приложен на крајот од трудот претставено е покривањето и составот на покривачот. 


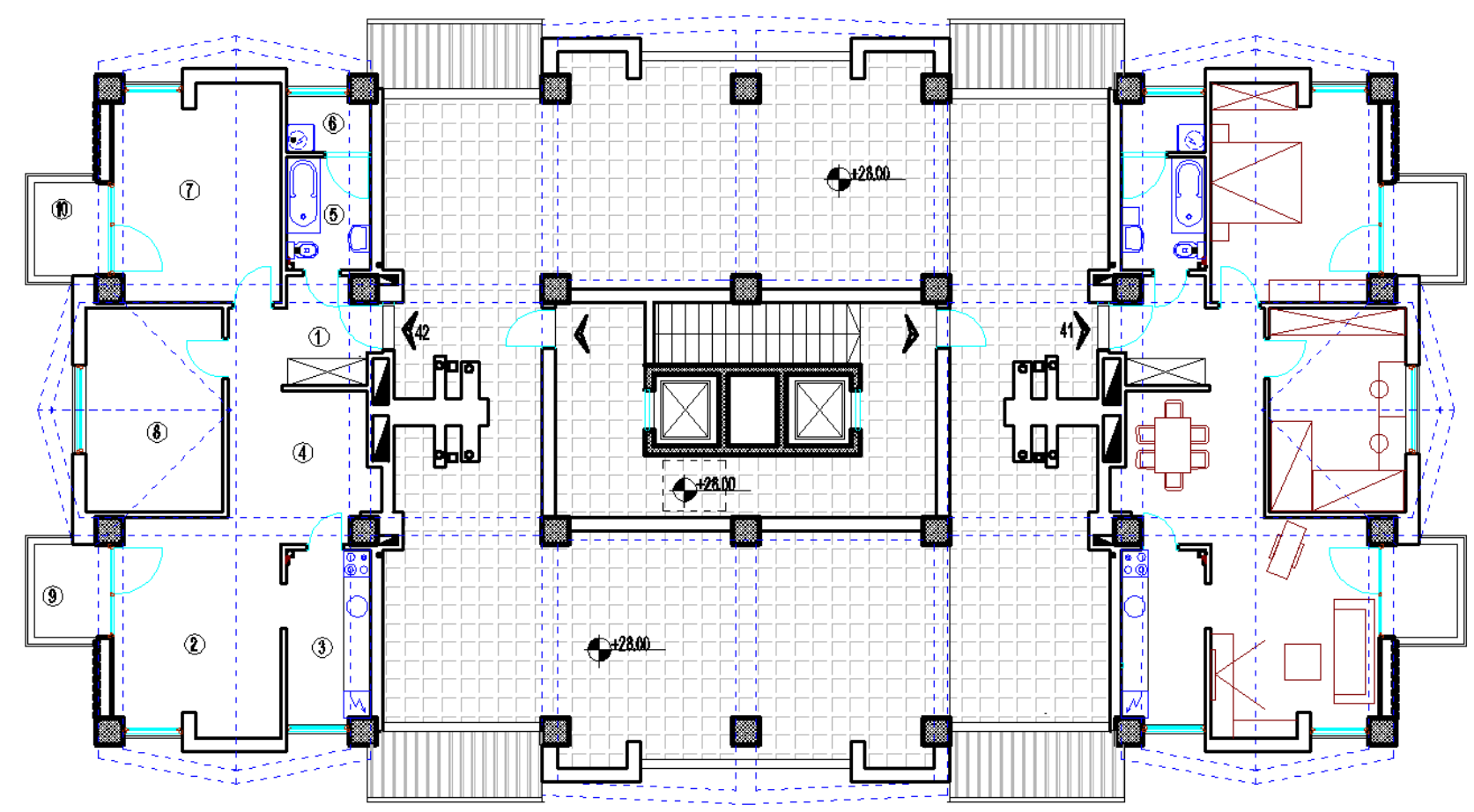

Фигура 77: Основа на поткровје - постоечка состојба ( стан 42/ 1, ходник 2, дневна соба 3 , кујна 4, трпезарија 5, купатило 6, помошна просторија 7, спална соба, 8, спална соба 9, балкон 10, балкон Извор: Катерина Петрушевска

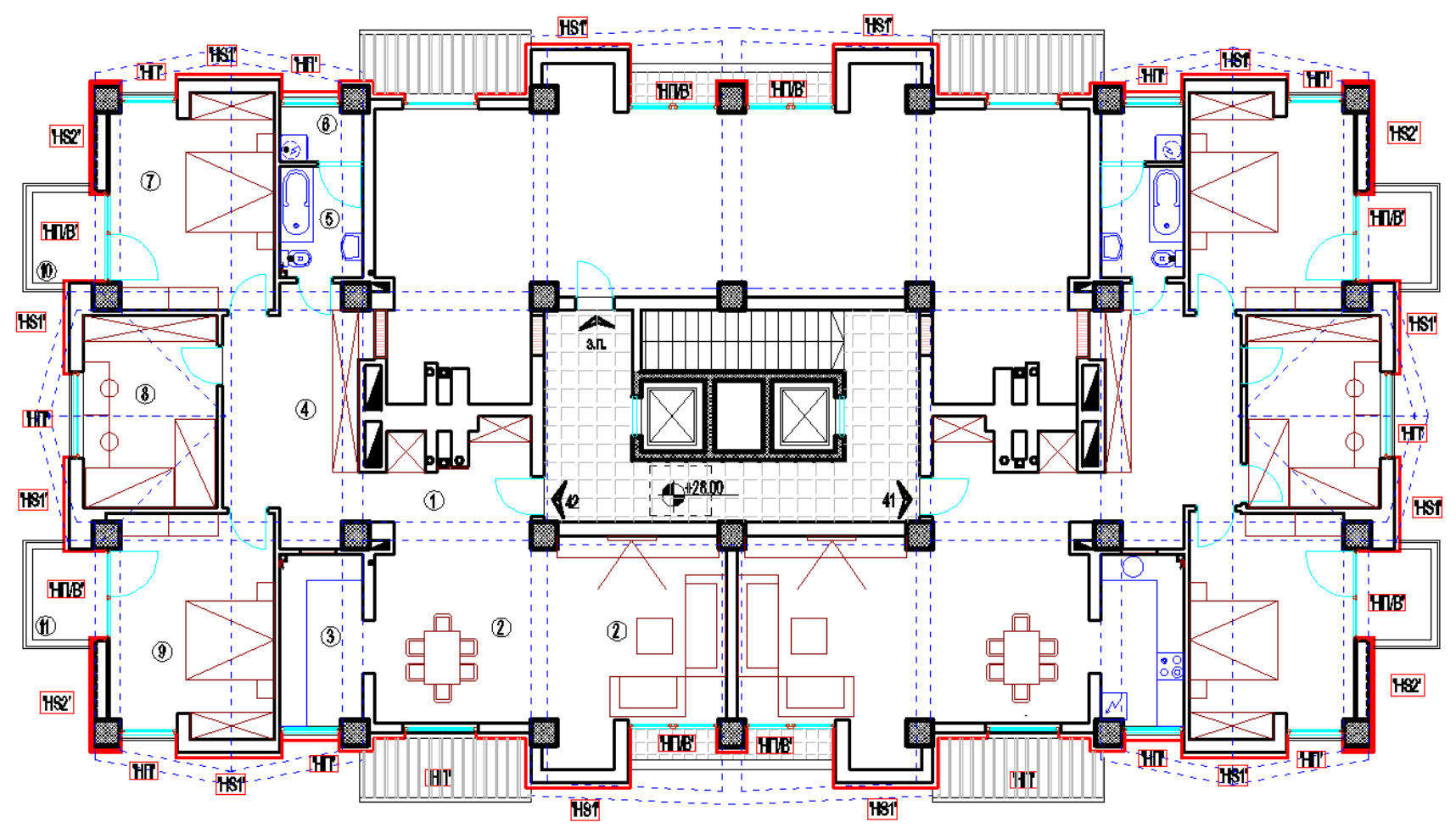

Фигура 78: Основа на поткровје -новопроектирана состојба Извор: Катерина Петрушевска 
Од фригура 79, се гледа составот на покривачот од пластифициран, ребраст челичен лим на потконструкција и изолација од минерална волна. Коефициентот за премин на топлина изнесува $\mathbf{U = 0 , 2 4} \mathbf{W} / \mathrm{m}^{2} \mathrm{~K}$ за делот на покривање врз постојните станови. Предвидена е изолација од минерална волна со д=15см. Доколку дебелината на слојот би била д= 20cм (минерална волна) тогаш потполно би бил задоволен максимално дозволениот $\mathbf{U}=\mathbf{0 , 1 8}$ $\mathrm{W} / \mathrm{m}^{2} \mathrm{~K}<0,20 \mathrm{~W} / \mathrm{m}^{2} \mathrm{~K}$.

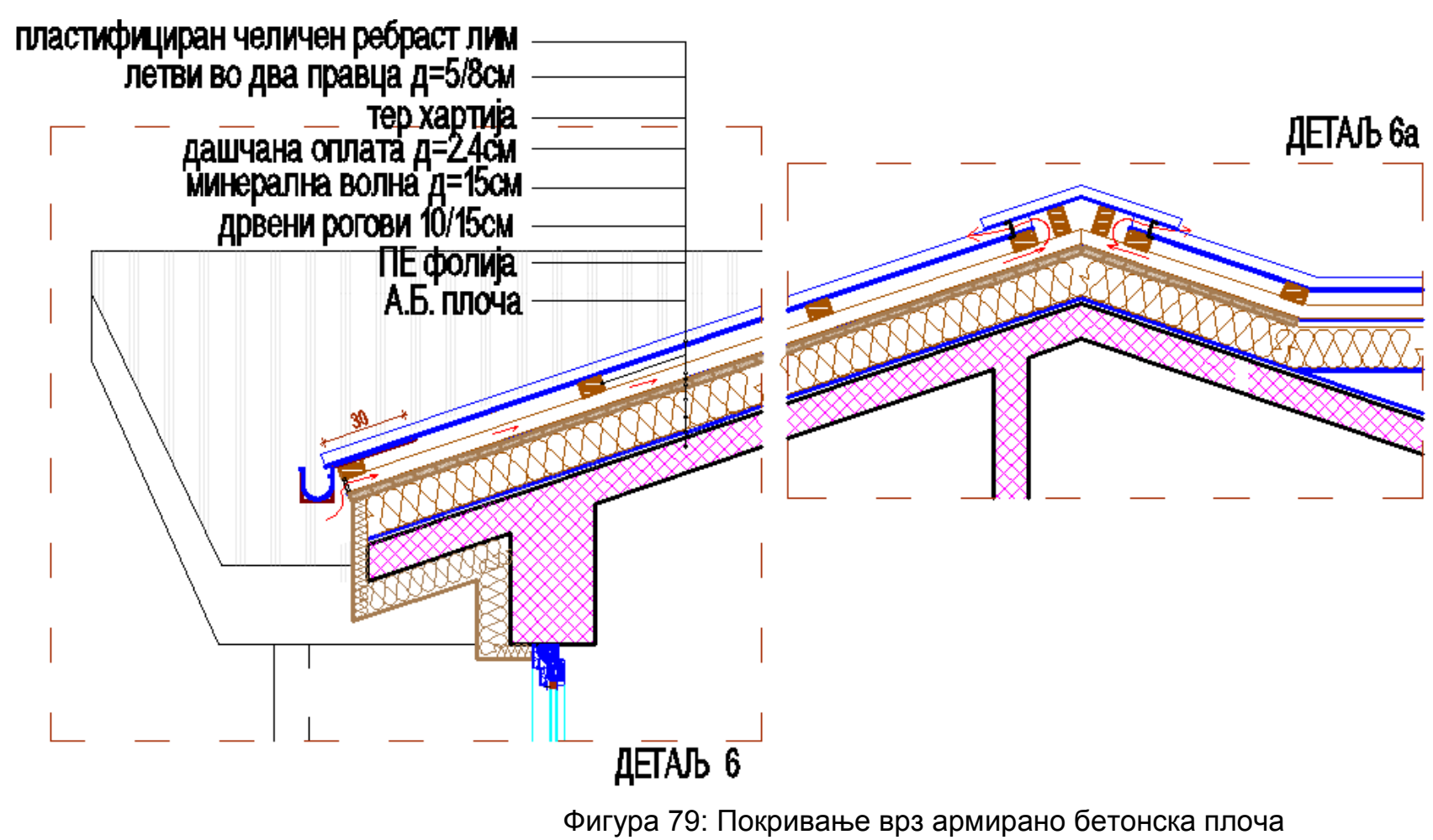

(кај постоечки станбени единици)

Извор: Катерина Петрушевска

Делот од терасата, пренаменет и затворен со кровна конструкција од челични решетки врз армирано бетонски греди, повторно е покриен со пластифициран ребрест челичен лим и сите останати потребни слоеви, фигура 80 , детаљ од пресек 1 - 1 во графичкиот Прилог бр.5 од трудот. Од тука за термоизолација од минерална волна со д=15см, пресметан е коефициент $\mathbf{U}=\mathbf{0 , 2 2} \mathbf{W} / \mathbf{m}^{2} \mathbf{K}>$ $\mathbf{0 , 2 0} \mathbf{W} / \mathrm{m}^{2} \mathrm{~K}$. Повторно доколку се препокрие целокупната кровна површина со изолација со д=20см , потполно би бил задоволен максималниот коефициент за премин на топлина. Ова решение е лесно за монтажа и економски оправдано. 


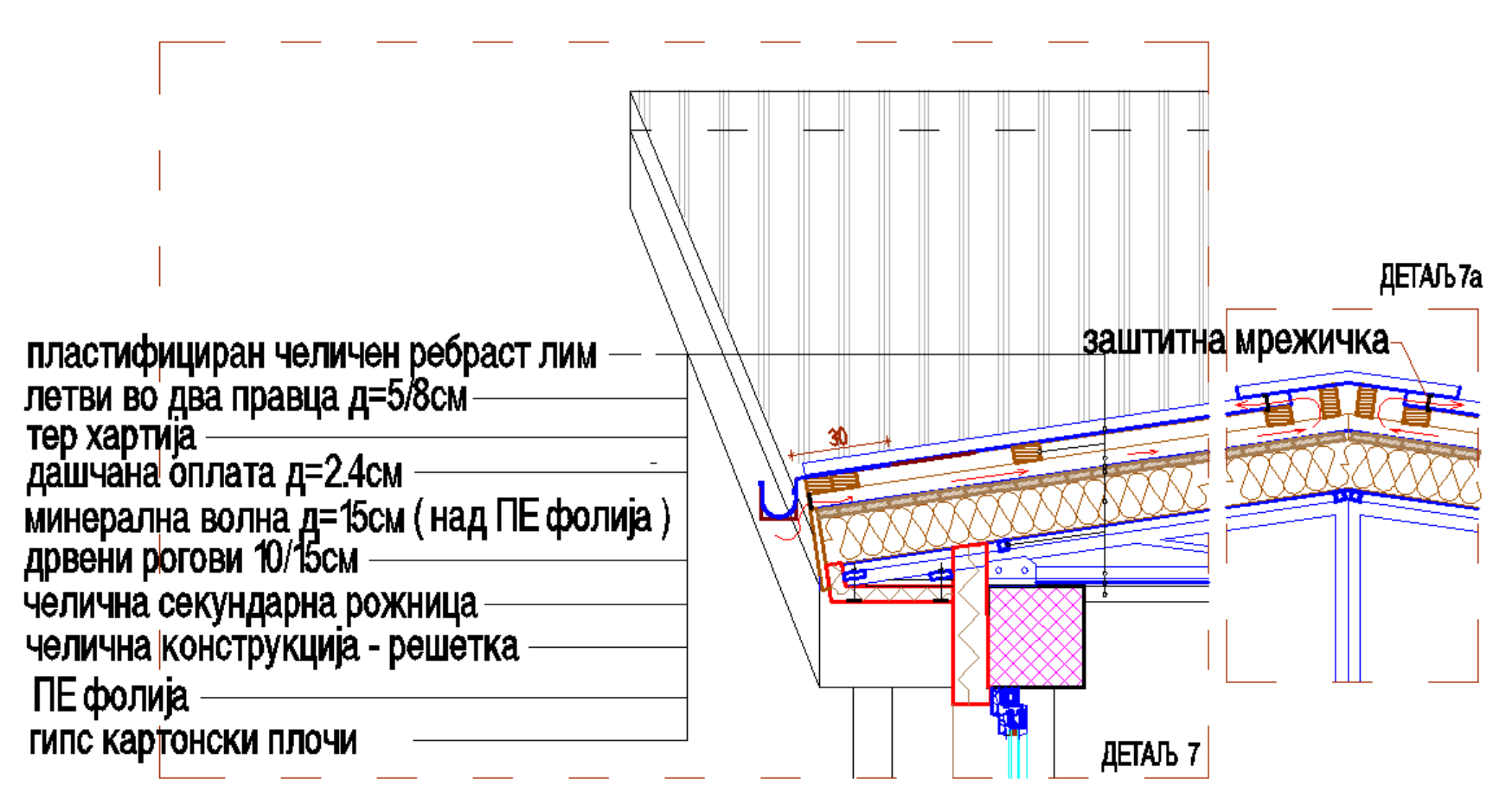

Фигура 80: Покривање врз челична решетка

(кај новопроектирани станбени единици)

Извор: Катерина Петрушевска

Според Директивата 2010/31/EU (за енергетски перформанси на згради) воведени се каталози и атласи за полесно решавање на оваа проблематика. Во овој случај, готови решенија се безполезни, заради употреба на армираниот бетон образложува Николовски (2012). Во обновата на ова поткровје и ново покривање, треба да се одберат практични метди заради лесна монтажа, но секако со соодветна ефикасност. Покрај термозаштитата потребна е заштита од пародифузија како и овозможена вентилација. Вентилацијата е потребна во случај на навлегување на кондензација и влажнење на термоматеријалот образложува Миловановиќ (Milovanovič н.п.). Во зависност од понудувачот на производот за покривање може да бидат разгледани и предложени соодветни фасонски елементи дизајнирани да овозможат вентилиран кров. Контактот на челичната решетка и минералната волна (фигура:80) битно е да се раздели со заштитна пародифузна фолија како не би ослабнала топллинската спроводливост $\lambda$ на минералната волна, потенцира Николовски (2011). Вредно е да се спомне дека пред да се одреди составот на покривачот во новопроектираната состојба, (од проектот од графичките прилози од трудот) размислувано е за покривање со "сендвич" панели од полиуретан и 
пластифициран челичен лим. Коефициентот за топлотна пропусливост приближно го задоволува максималниот, но во консултација со инжењери за термичка инсталација ова решение не е соодветно од причина што ќе нема термички ефект врз армиранобетонските коси плочи. Причината е заради потреба од дополнителна потконструкција која ќе ги раздели изолацијата и косата плоча. Друга пречка би била потешкотијата при монтажа или заптивање на споевите кај косините, а секако улога имаат и фринансиските причини.

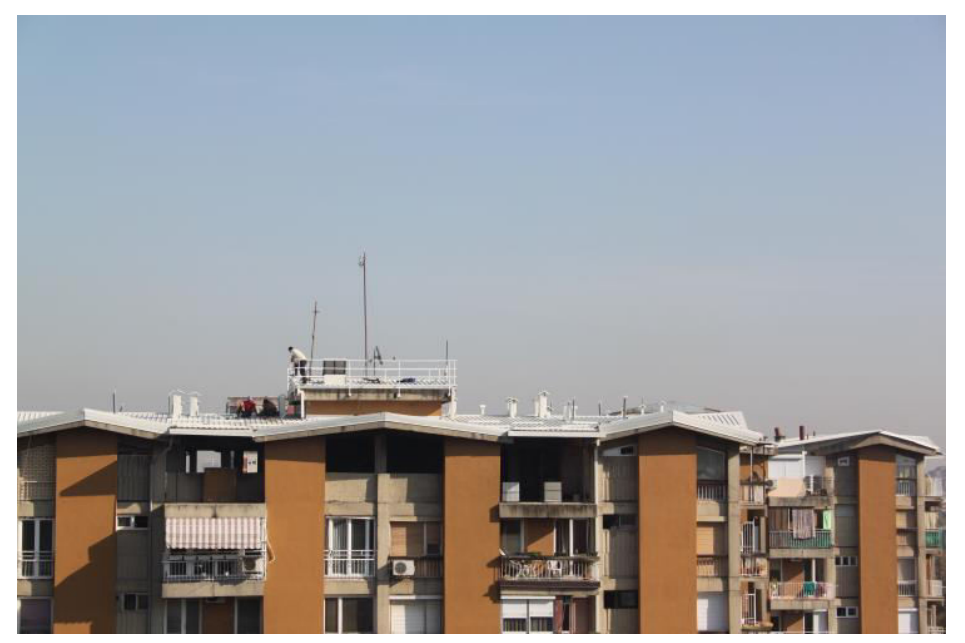

Фигура 81: Изведба на нов покривач кај соседната кула Извор:Катерина Петрушевска

\section{Надворешни зидови}

Изборот на термичка изолација и место на вградување е врз основа од истражувањето во поглавие 5.7.1 и 5.7.2 од трудот. Од сите решенија на место на поставување на термоизолација на надворешен sид, (надвор, внатре, средина) најповолно решение за овој вид објекти е поставеност на изолацијата од надворешната страна. Причините за изборот на местоположбата може да се увидат во Табела бр.1. На овој начин е лесна монтажата, непречено одвивање на градежните работи, без вознемирување на станарите од внатре и е по исплатливо. Што се однесува до топлинските мостови, на овој начин тие се совладани. Поради тоа изборот е̉ систем од фасада која претставува надворешна термичка изолација. Една од мерките за енергетска ефикасност е комплетна обработка на фасадите со композитни системи за надворешна термоизолација. Материјалот е експандиран полистирен, кој задоволува од еколошки, термички и економски фрактори. Овој систем е наменет за трајно 
подобрување на градежно - фризичките карактеристики на градежните објекти како кај новоградби така и при поголема реконструкција на постоечки објекти.

Системот се состои од:

\section{1.Лепило}

2.Термоизолација

3.Типли (основно прицврстување)

4.Основно малтерисување

5.Заштита (текстилна мрежа од стаклени влакна)

6.Завршно малтерисување со грундирање во зависност од системот или премазот (меѓуслој)

7.Делови од прибор, платнени аголници, приклучоци и завршни профили, профили за дилатациони жлебови, окапници, подножни профили.

Заштитата од термичките мостови е решена со вградување на изолациониот материјал на надворешниот фрасаден sид со што треба да се добие нова фасадна обвивка, која од вертикала преминува во хоризонтала (кров и подрумски таван). Изведбата на нова фасадна обвивка, дозволува обнова без раселување на станарите. Според пресметките во елаборатот за градежна фризика во табела HS1 Прилог бр.3 од трудот, коефициентот за премин на топлина изнесува:

$\mathrm{U}=0,27 \mathrm{~W} / \mathrm{M}^{2} \mathrm{~K}<\mathrm{Umax}=0,35 \mathrm{~W} / \mathrm{m}^{2} \mathrm{~K}$ (задоволува)

- (sид од керамички блок, фригура:82)

$\mathrm{U}=0,28 \mathrm{~W} / \mathrm{m}^{2} \mathrm{~K}<\mathrm{Umax}=0,35 \mathrm{~W} / \mathrm{m}^{2} \mathrm{~K}$ (задоволува)

- ( мид од армиранобетонско платно, фигура:83) 


\section{$(\mathrm{U}=0.27 \mathrm{~W} / \mathrm{m} 2 \mathrm{~K})$}

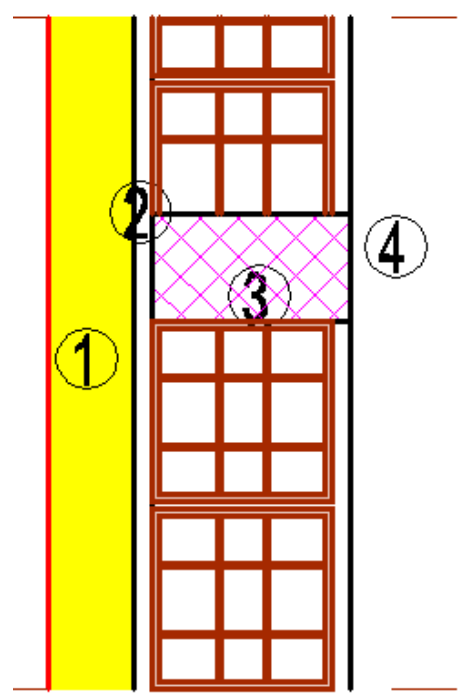

(1)

завршно малтерисување

текстилна мрежа од стаклени влакна

основно малтерисување

ТИПЛИ

експандиран полистирен $\mathrm{A}=12 \mathrm{~cm}$ лепило

(2) постоечка фасада

(3) шуплива блок тула д=25cм

(4) малтер $\mathrm{g}=2.5 \mathrm{~cm}$

Фигура 82: надворешен sид од фрасадна шуплова блок тула д=25cм,

изолиран со експандиран полистирен

Извор: Катерина Петрушевска

$(\mathrm{U}=0.28 \mathrm{~W} / \mathrm{m} 2 \mathrm{~K})$
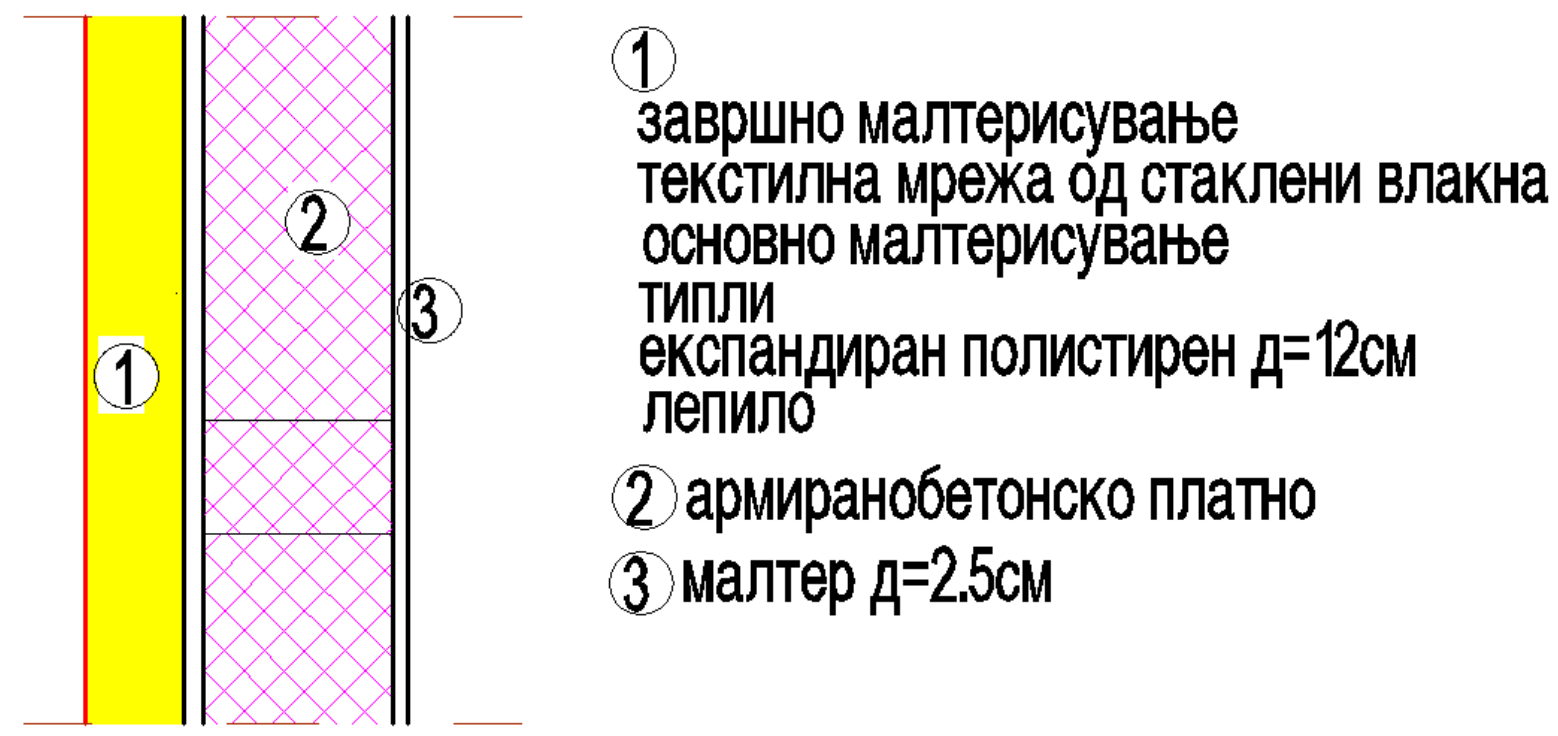

Фигура 83: надворешен зид, армиранобетонско платно изолиран со експандиран полистирен

Извор: Катерина Петрушевска

Од фигура 72, се гледа дека надворешниот sид е без изолација со коефициент $\mathrm{U}=1,55 \mathrm{~W} / \mathrm{M}^{2} \mathrm{~K}$. Според пресметките за коефициентот на пропусливост на топлина во табела HS1 во Прилог бр.3, потребната дебелина на слојот од изолацијата е 12cм за надворешниот sид изведен со керамички блок. Дебелината на слојот од изолацијата за надворешниот зид од 
армиранобетонското платно изнесува $(5+8 \mathrm{~cm})=13 \mathrm{~cm}$. Овој податок е пресматан според правилникот на О.К. (2012) и ги задоволува максимално дозволените коефициенти за премин на топлина низ градежните конструкции. Пресметката на $U$ коефициентот на премин на топлина, за надворешен sид, преку пример може да се види во табела бр 12; и фригура 82.

Табела 12: HS1, Прилог бр.3

HS1

\begin{tabular}{|c|l|c|c|c|}
\hline р.бр & $\begin{array}{l}\text { Вид на } \\
\text { конструкција }\end{array}$ & $\begin{array}{c}\text { Дебелина } \\
\mathrm{d}=(\mathrm{m})\end{array}$ & $\begin{array}{c}\text { Коефициент на } \\
\text { проводливост } \\
\Lambda=[(\mathrm{W} / \mathrm{mK})]\end{array}$ & $\begin{array}{l}\text { Термички } \\
\text { отпор } \\
\mathrm{R=d} / \lambda\left(\mathrm{m}^{2} \mathrm{~K} / \mathrm{W}\right)\end{array}$ \\
\hline 1 & $\begin{array}{l}\text { Експандиран } \\
\text { полистирен }\end{array}$ & 0,12 & 0,04 & 3 \\
\hline 2 & $\begin{array}{l}\text { Благороден } \\
\text { фрасаден малтер }\end{array}$ & 0,03 & 0,70 & 0,042 \\
\hline 3 & $\begin{array}{l}\text { Керамички } \\
\text { шуплив блок }\end{array}$ & 0,25 & 0,61 & 0,409 \\
\hline 4 & $\begin{array}{l}\text { Варов малтер } \\
\text { продолжен }\end{array}$ & 0,02 & 0,85 & \\
\hline
\end{tabular}

$\sum R=3.474$

Од табела3.4.1.1(MKC EN ISO 6946/ A1)

Rsi $=0.13$

Rse $=0.04$

Од тука $\mathrm{Rt}=\mathrm{Rsi}+\sum \mathrm{R}+\mathrm{Rse}$

$\mathrm{Rt}=0.13+3.474+0.04=3,644$

$\mathrm{U}=1 / \mathrm{Rt}=1 / 3.644=\mathbf{0 , 2 7} \mathrm{W} / \mathrm{m}^{2} \mathrm{~K}<\mathrm{Umax}=\mathbf{0 , 3 5} \mathbf{W} / \mathrm{m}^{2} \mathrm{~K}$ (задоволува)

\section{Меѓукатни конструкции-подови}

Под приземјето, се предлага плочата да се обложи со изолација од камена волна со специфична тежина од $15 \mathrm{kr} / \mathrm{m}^{3}$, со дебелина која нема да претставува висински проблем во подрумските простории-(фигура:84). Поради ограничената висина на просторот, во подрумот на плафонот не може да се вгради изолација со поголема дебелина на слојот од 5см. Поради тоа, не може да се задоволи максималниот U коефициент. 
$\mathrm{U}=\mathbf{0 , 5 6} \mathrm{W} / \mathrm{m}^{2} \mathrm{~K}>\mathrm{Umax}=\mathbf{0 , 3 5} \mathbf{W} / \mathrm{m}^{2} \mathrm{~K}$ ( не задоволува )

Но сепак коефициентот на топлотна пропусливост е подобрен во однос на постоечката состојба. Од табела Д1- (Под над негреан подрум постоечка состојба - Прилог бр.2) и тбела д1- (под над негреан подрум со изолација Прилог бр.3), може да се направи компарација во смисла на подобрувањето на состојбата. Материјалите за термо заштита ако не се соодветно заштитени може да се ронат. Камената волна кај плафонот од подрумските простории, за разлика од експандираниот полистирен, полесно се одржува во смисла што не се рони. Но сепак постои опасност од оштетување и одронување на влакната низ времето. Заради тие причини се предлага заштита од водоотпорни гипскартонски плочи на потконструкција. Во овој случај треба да се направи тестирање на производот, или сертификат од производителот по однос на впивање на влага. За додатна заштита може да се постави пластифицирана фолија на контактот меѓу изолацијата и водоотпотниот гипс.

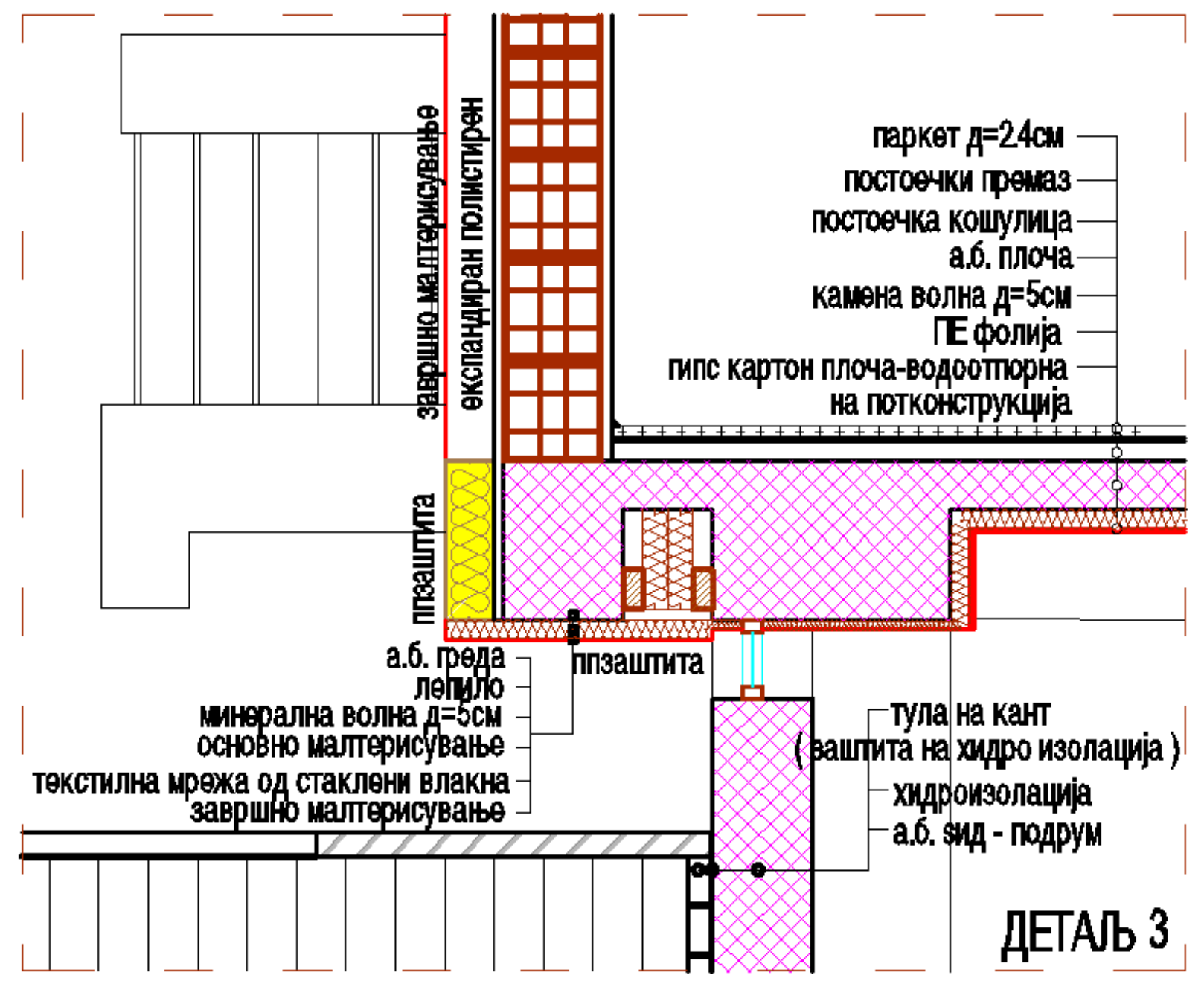

Фигура 84: подна конструкција, помеѓу приземје и подрум-новопроектирана Извор: Катерина Петрушевска 
Кај новодобиените или проширување на становите на поткровје во новоформираниот поден слој, ставена е изолација од еластифициран полистирен. Всушност на оваа позиција се применети стандардните слоеви на под во формирање на станбен простор. Постоечките подни облоги не се отстранети, од еколошки причини, а и нема потреба бидејќи висинскиот простор е задоволен. Новите слоеви се добиени со поставување на еластифициран полистирен за заштита од пренос на бучава, а израмнувањето се постигнува при поставување на подлога од цемент. Лицето на подот е паркет- фигура: 85.

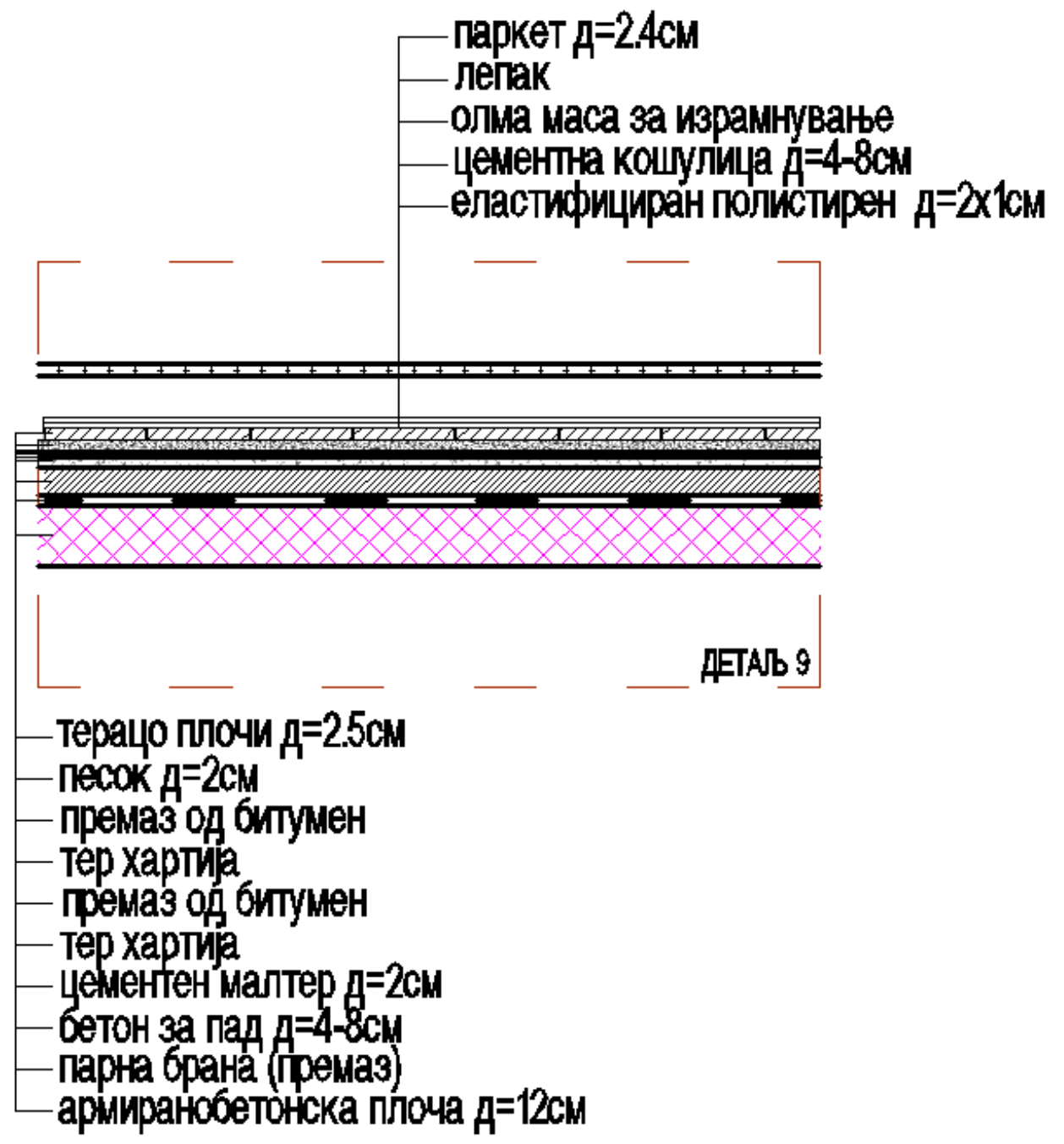

Фигура 85: состав на рамна проодна тераса, со подлоги за станбен простор врз истата Извор: Катерина Петрушевска

\section{Балкони}

Во пресметките претставени во табела HS(тм) во Прилог бр.3, балконските топлински мостови делуваат и се пресметуваат површински на обвивката на фасада. Врз основа на пресметките добиени во Прилог бр.3 истите учевствуваат со 10-12\% врз загубата на енергија за греење. Во 
новопроектираната состојба, применет е предлогот на Николовски (2012) како и на Башиќ и др. (Bašič et al. 2008) за облагање на балконските конзоли од сите страни вклучувајќи ја и нагазната површина (во случајите каде што постои можност). Со едно вакво предлог решение се избегнуваат топлинските мостови на делот од обвивката на фрасада кој се однесува на спојот sид - балконска конзола. Од графичкиот приказ може да се види дека е посветено внимание за противпожарна заштита. Истата продолжува континуирано со поставување на минерална волна на секој нов кат на позиција пред меѓукатната конструкција или над прозорските отвори и балкони. Коефициентот на премин на топлина изнесува:

$\mathrm{U}=1 / \mathrm{Rt}=1 / 2,062=\mathbf{0 , 4 8 5} \mathbf{W} / \mathrm{m}^{2} \mathrm{~K}>\mathrm{Umax}=\mathbf{0 , 3 5} \mathbf{W} / \mathrm{m}^{2} \mathrm{~K}$ (незадоволува). Инжењерите за термотехника, врз основа од геометриски аспект на фасадата ги пресметуваат со 10-15\% од вкупната површина на надворешните sидови.

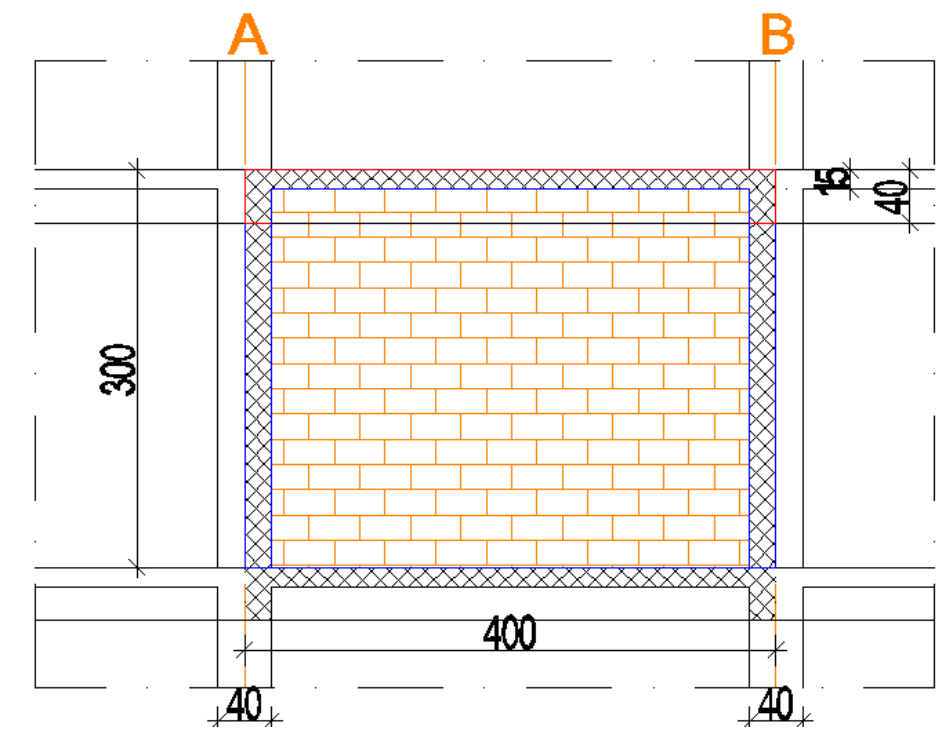

Фигура 86: Процентуално учество на топлинските мостови на фасада Извор: Трајановски (2014)

Според фигура: 86, површината на модулот изнесува 12м². Површината на sиданиот дел изнесува $10,2 \mathrm{M}^{2}$. Од тука бетонските површини влегуваат со $14,5 \%$. Резултатот варира во зависност од појавувањето на греди на фрасадата. Врз основа на тоа може да се пресмета просечен коефициент на премин на топлина за надворешни зидови:

$U_{\text {пр }}=U_{\text {нs }} \times 0,85+U_{\text {ep }} \times 0,15=0,27 \times 0,85+0,48 \times 0,15=0,230+0,072=0,302 \mathrm{~W} / \mathrm{m}^{2} \mathrm{~K}$ $\mathrm{U}_{\text {пр }}=0,302 \mathrm{~W} / \mathrm{m}^{2} \mathrm{~K}<\mathrm{Umax}=0,35 \mathrm{~W} / \mathrm{m}^{2} \mathrm{~K}$ (задоволува). 


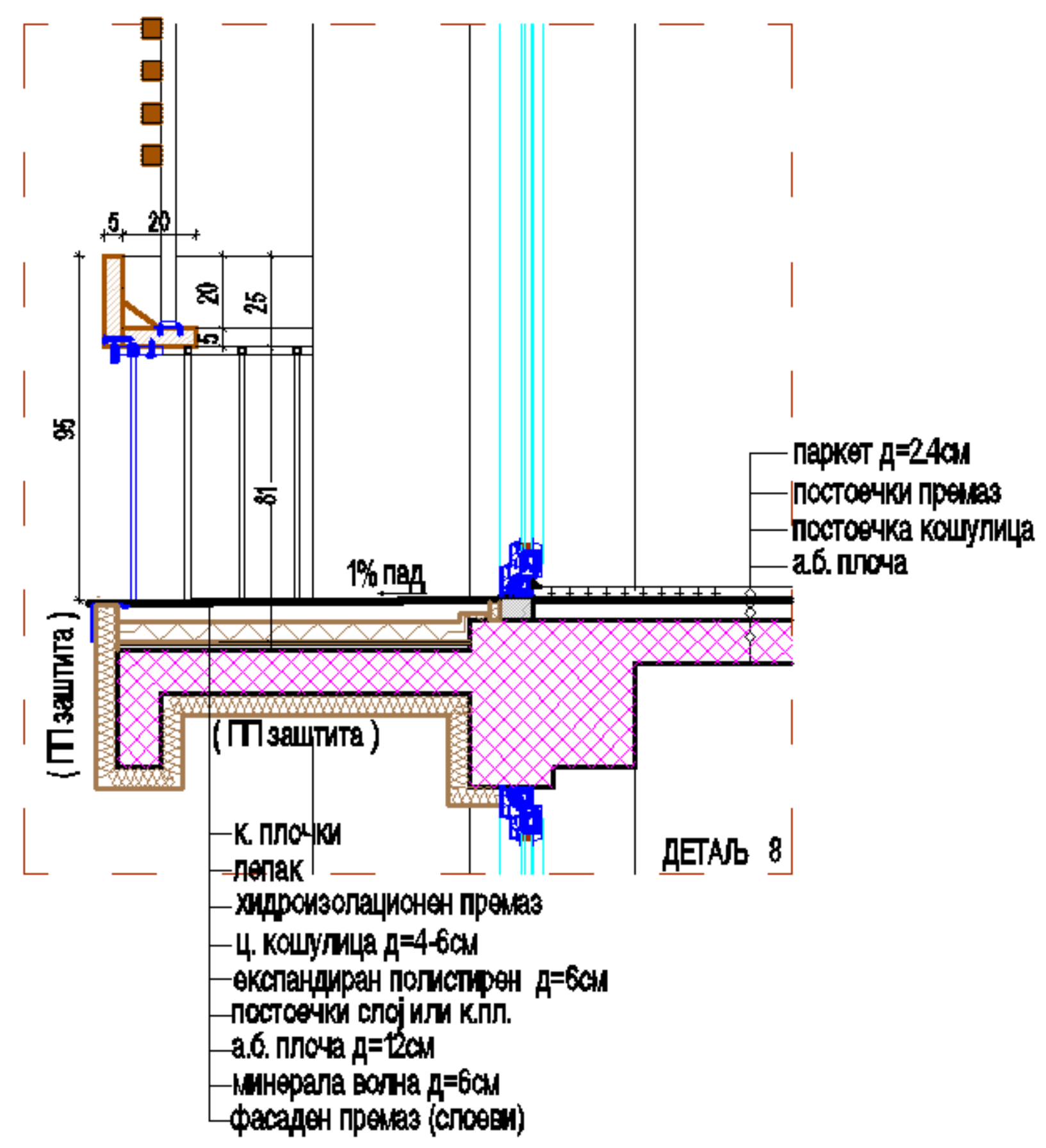

Фигура 87: Детаљ на балконска конзола, предлог решение за изолација Извор: Катерина Петрушевска

Со овој начин на изолација и облагање заради заштита од влијанието на топлински мостови, добиваме промена на нагазната површина од балконската конзола. Истовремено постои опасност од намалување на висината на балконската ограда. Постоечката висина на оградата, од објектот се гледа во фигура бр:74 и истата изнесува 91см. Во новата состојба извршена е 
интервенција кај гелендерот, со негова замена. Предлогот е поставен од две причини. Првата е заради дотраената состојба на истиот и утврдување дека на поголемиот дел од балконски огради (и на повисоките катови) е целосно отстранет. Втората причина е заради заштита, се поставува соодветен ракохват од дрвени талпи со тоа што вертикалната преминува од 15 на 25 см, па одтука висината на новата состојба изнесува 95. На овој начин е извршена интервенција и не само што е задржана постоечката висина туку е зголемена за 5см. Овој предлог е изработен заради задржување на автентичноста на објектот и не навлегување во дополнителни трошоци. Доколку прописите бараат поголема висина од постоечката или предвидената ограда, во тој случај потебна е целосна замена на истата.

\section{Прозори и врати на фрасада}

Прозорците и вратите на фасадата се предлага да се заменат со нови. За изборот на новите прозорци и врати на фасада, треба да се земат во предвид сенчевите фактори (светлосни и енергетски). Истите влијаат на одредување на карактеристиките и перформансите на изборот на стакло. Во изборот на новите прозорци и врати за фасада, разгледувани се варијанти на типови на застаклување, избор на рамка и соодветна монтажа која треба да ги намали топлинските мостови. Како втора варијанта, разгледувано е решение за поставување на полици на фрасада, за заштита од сонце во случај кога не би се одлучиле за стакла со високи перформанси. Трета варијанта би биле перголите за засенување поставени на балконите (фигура 93,94). Количеството на топлина предизвикана од сончевите зраци може да се редуцира со избор на стакло со премаз со високи перформанси, со што се попречува зрачењето и прегрејувањето, а се внесува светлина. Овие типови на стакла се наречени селективни стакла. Застаклените делови на фасадата во зимскиот период од годината карактеризирани се со поголема загуба на топлинска енергија во однос на другите градежни елементи. Во лето истите се прегреани и потребата за ладење на просториите е поголема. Затоа треба да се најде решение каде што во зима ќе постои можност за внесување на сончева светлина, додека во летниот период потребна е соларна конрола или селективно пропуштање на сончевите зраци. Според Николовски и Костадиновски (2010) стаклата со соларна контрола може да бидат : 
- апсорпциско стакло (стакло во боја кое што дел од сончевата енергија ја апсорбира во себе, а дел се внесува во просторијата).

- Стакло со премаз од метализиран слој кој што ја рефолектираат сончевата енергија и го спречуваат директното прегрејување.

- Стаклопакети со вградени ролетни за заштита од сонце.

Во изборот на стакла разгледувани се составите на стаклопакети кои се состојат од двослојни, трослојни стакла исполнети со благороден гас кој делува како топлински изолатор. Покрај стаклата кои имаат соларна контрола од метализирани слоеви, постојат стакла со метализирани слоеви со ниска емисија. Истите може да бидат нанесени од внатрешноста на стаклопакетот и служат да ја вратат или задржат топлината во греаните простории. Секако овие решенија се поскапи. Во магистерскиод труд предложена е варијанта на избор на двослоен стакло пакет, со вградени ролетни за заштита од сонце (на јужната и западната фасада). Истиот е составен од два слоја на стакло затворено во фрабрика и разделени со херметички затворен простор. Коефициентот за топлотна пропусливост треба да се гарантира од производителот и истиот да го задоволи максимално дозволениот коефициент $\mathrm{U}=1,7 \mathrm{~W} / \mathrm{M}^{2} \mathrm{~K}$ од Правилникот (2012). Вградените ролетни се софистицирано решение затоа што можат да претставуваат, заштита од упад на сончевите зраци и прегрејување поготово во повисоките катови на јужната и западната страна. Ова решение би требало да се употреби доколку дозволува фринансиската состојба. Предложени се ПВЦ (PVC) рамки бидејќи ги исполнуваат условите за добри изолациони карактеристики, а одговараат по однос на фринансии за станбени објекти, естетски и функционално. Од друга страна, на дел од постоечката фасадата заменети се старите прозорци со нови, а изборот е ПВЦ рамка. Според Хазука (Hazucha 2010), најголем процент при реконструкции, заземаат ПВЦ рамките од причина што се најекономични, лесни за одржување и трајни. Алуминиумот е познат по високата спроводливост на топлина, но денес постојат и пософистицирани решенија од современи алуминиумски рамки со таканаречени топлински прекини кои претставуваат и поскапи решенија и не соодетствуваат на платежната моќ. Според Башиќ и др. (Bašič et al. 2008) треба да се обрне внимание при изведбата и поставувањето на новите прозорци. Каков и да биде изборот на перформансите на рамката и стаклото, ако правилно не се вградат прозорците, или ако не се исправно монтирани, U 
вредноста може да се влоши за 0,5 W/M²K, потенцираат Николовски и Костадиновски (2010). Проблемите се јавуваат во контактот со керамички блокови или армиран бетон, кои истите имаат висок коефициент на спроведување на топлината. Топлинските мостови во овие делови ќе станат причина за големи топлински загуби. Заради тоа по вградување на прозорските рамки се поставува термоизолација која треба да ја препокрие позорската рамка соодветно.

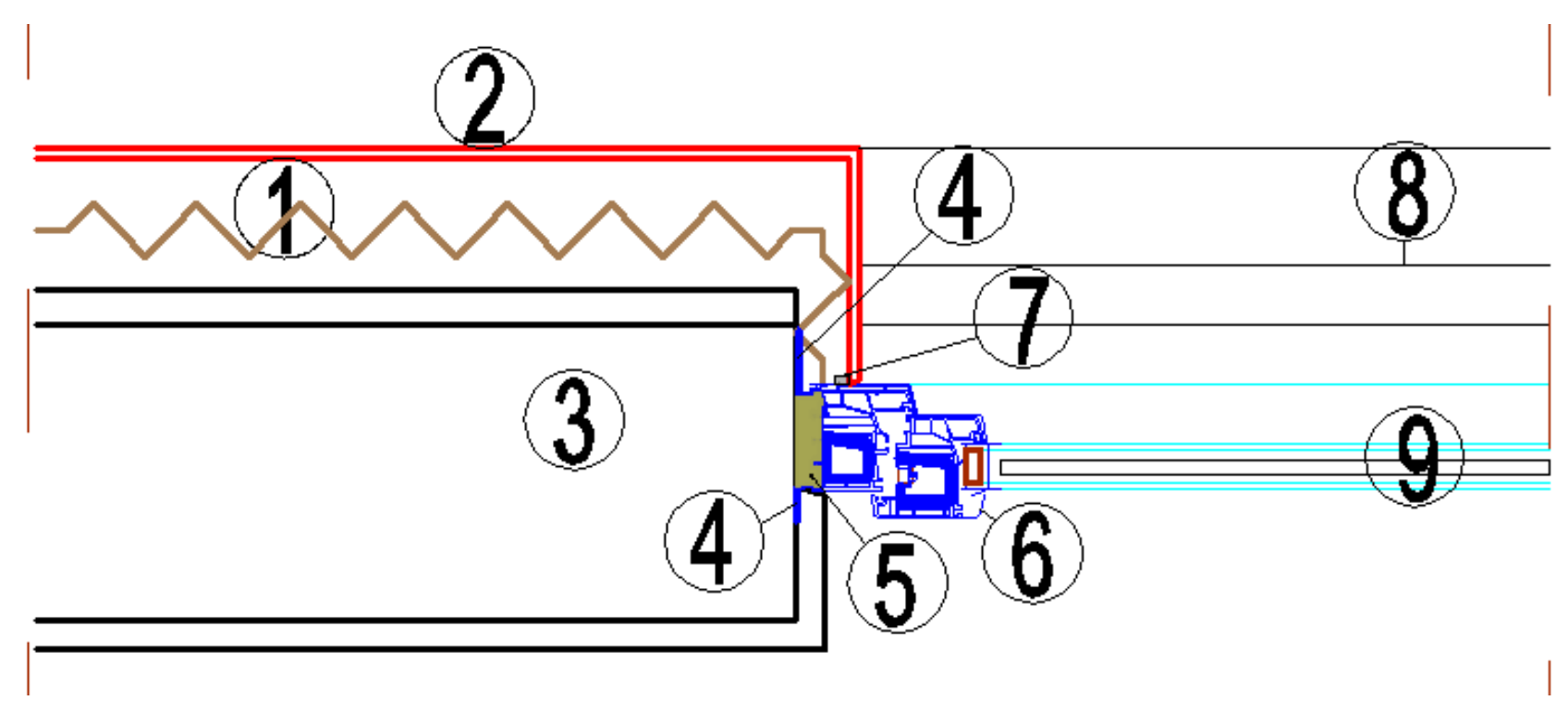

Фигура 88: Минимизирање на топлински мостови кај прозорец и sид

1. Експандиран полистирен д=12cм со $5 \mathrm{~cm}$ преклоп на ПВЦ рамка, 2. Завршна обработка,

3. Постоечки sид, 4. Заптивна фолија, 5. Пур пена, 6. ПВЦ рамка со двослојно стакло,

7. Компресиона лента, 8. Ограда, 9. Вградени ролетни

Извор: Катерина Петрушевска

На фигура 88, се третира делот каде што би се појавиле топлински мостови и направен е обид за нивно ублажување. Во графичкиот дел од трудот, во Прилог бр.5, претставен е комплетен третман на облогата на фасада со што би се зеле во предвид и замената на стари отвори со нови во соодветен избор. Со нивна замена би се подобрила $U$ вредноста на прозорската рамка и стакло.

Бидејќи сончевото зрачење е изразено на јужната и западната страна од зградата, направен е обид, за заштита од сончево прегрејување со алтернативни решенија. Разгледуван е принципот на Лехнер (Lechner 2013) на заштита од сонце со сончеви полици пред отворите на фасадата. Според 
астрономски таблици за Скопје од Солартопо (Solartopo 2014), превземени се податоците за сончевите агли, но во фигура 90,91,92, се гледа дека овој тип на заштита од сончево зрачење не одговара за овој објект. Според упадните сончеви агли ова решение е не соодветно од аспект на монтажа, заштита од снег и ветер и останати економски причини. Полиците се предимензионирани и не одговараат за наши услови. Покрај тоа парапетот на отворите на зградата е нула, така да дополнително има потреба од зголемување на должината на полиците. Може да се заклучи дека денешните коефициенти на стакла и рамки можат да пружат соодветна сончева и топлотна заштита, а како дополнителни решенија и варијанти можат да се земат во обзир, инегрирани ролетни во стаклопакетите. Од фигура 93,94, може да се види уште еден обид за заштита од сончевото прегрејување со поставување на заштитни перголи на ивиците од балконите на јужната и западната, а делумно и источната страна.
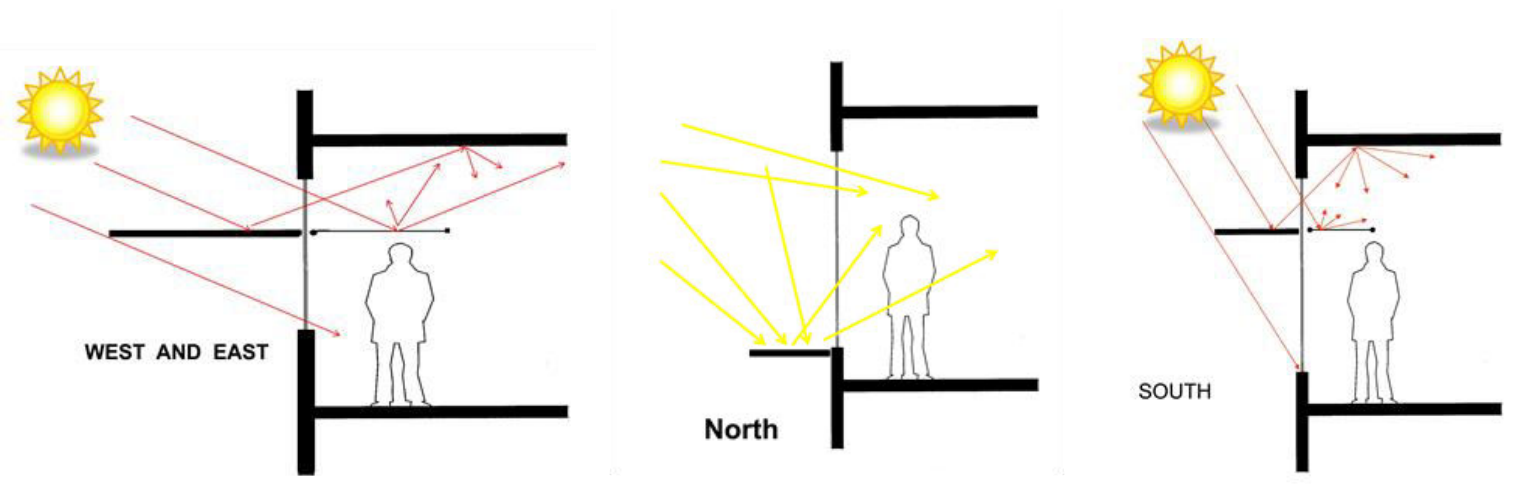

Фигура 89: Daylighting light shelf ( Рефрлектирачки сончеви полици ) Извор : Lechner (2013) - Семинар за енергетска ефикасност 


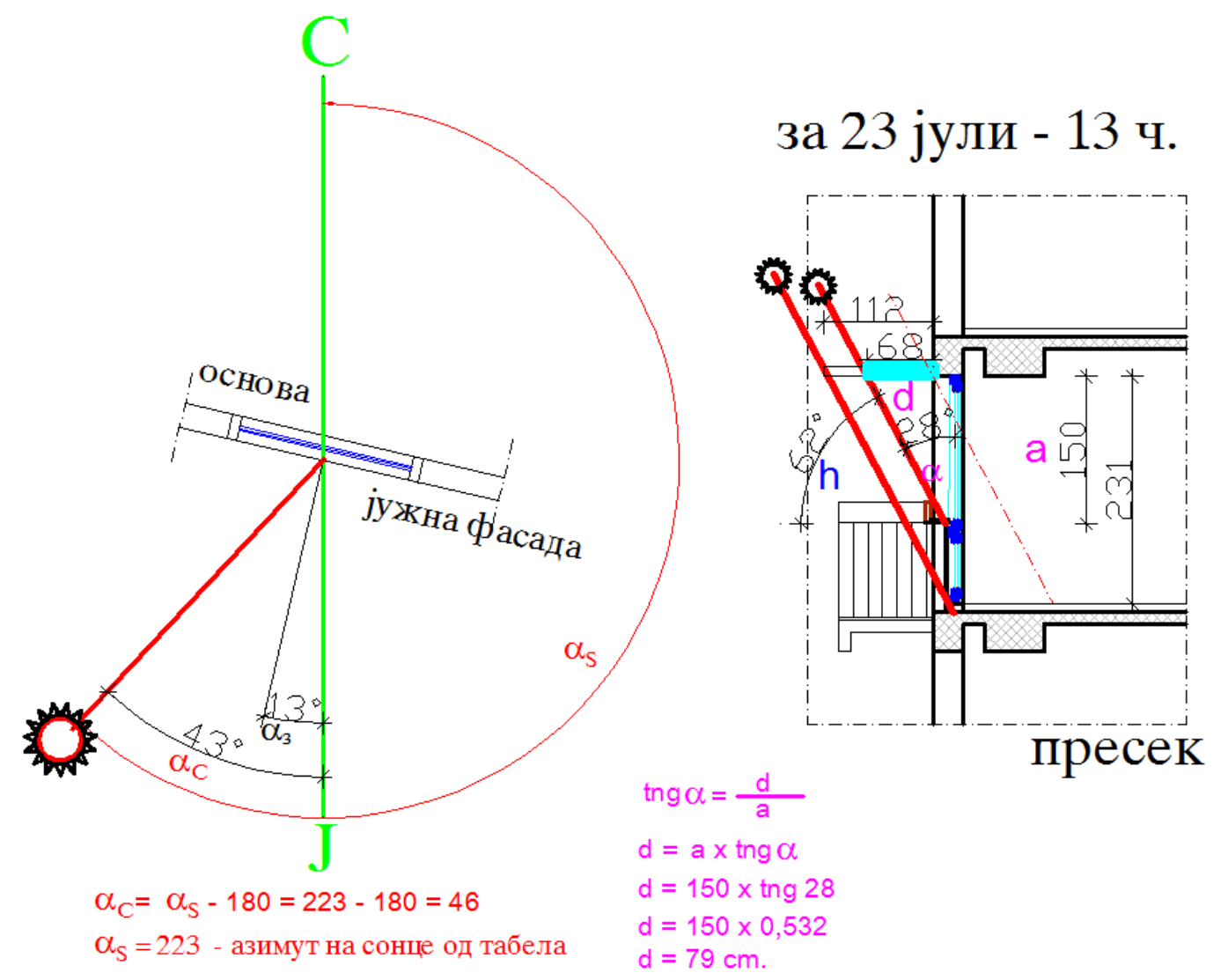

Фигура90: Пресметка на упадни сончеви агли за димензионирање на заштитна полица (Решението е не соодветно и не исполнува) Извор : Катерина Петрушевска (2013)

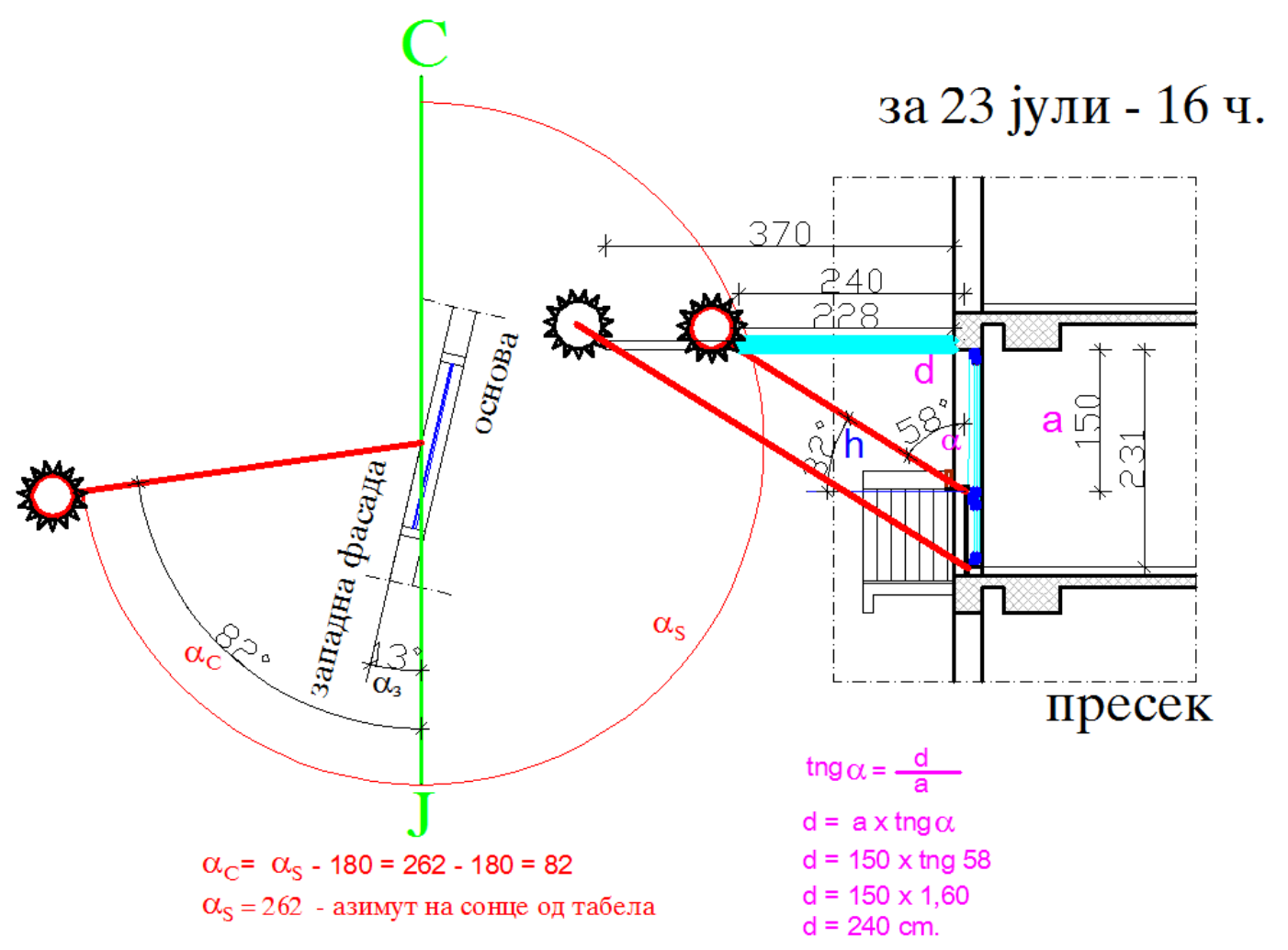

Фигура 91: Пресметка на упадни сончеви агли (не соодветно и не исполнува)

Извор : Катерина Петрушевска (2013) 


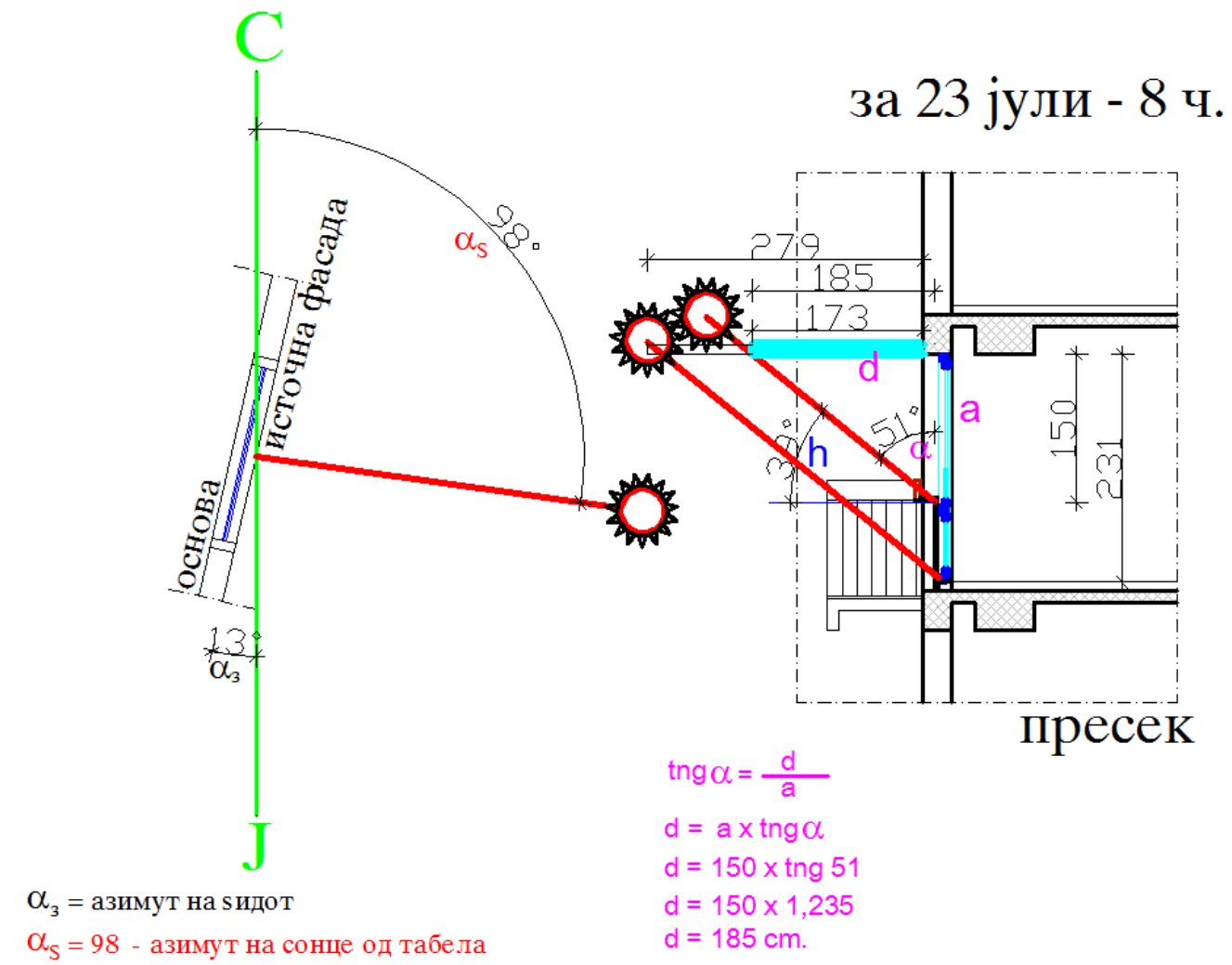

Фигура 92: Пресметка на упадни сончеви агли за димензионирање на заштитна полица (Решението е не соодветно и не исполнува) Извор : Катерина Петрушевска (2013)

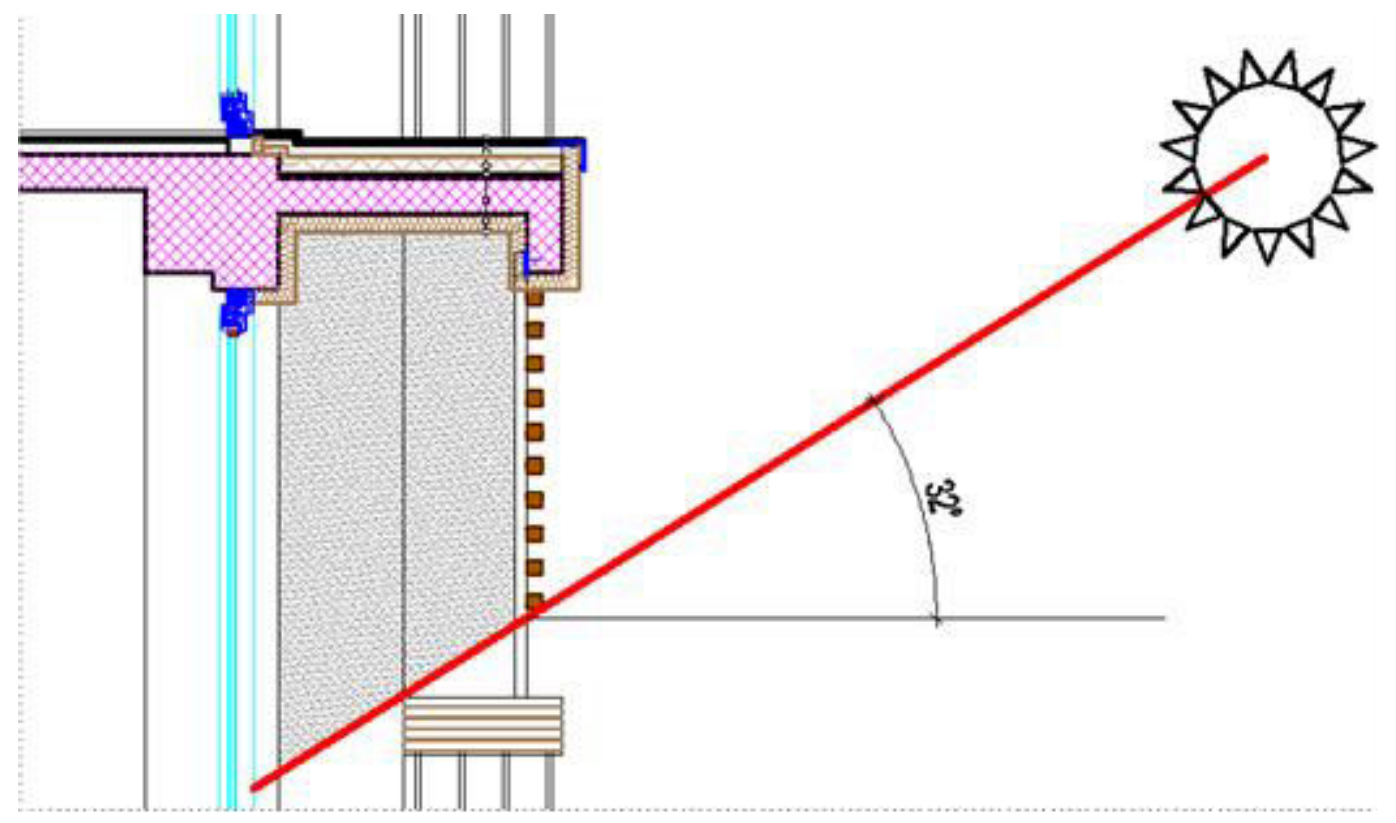

Фигура 93: Заштитни перголи, монтирани на балкон на западна страна 23 јули, 164. Извор : Катерина Петрушевска (2013) 

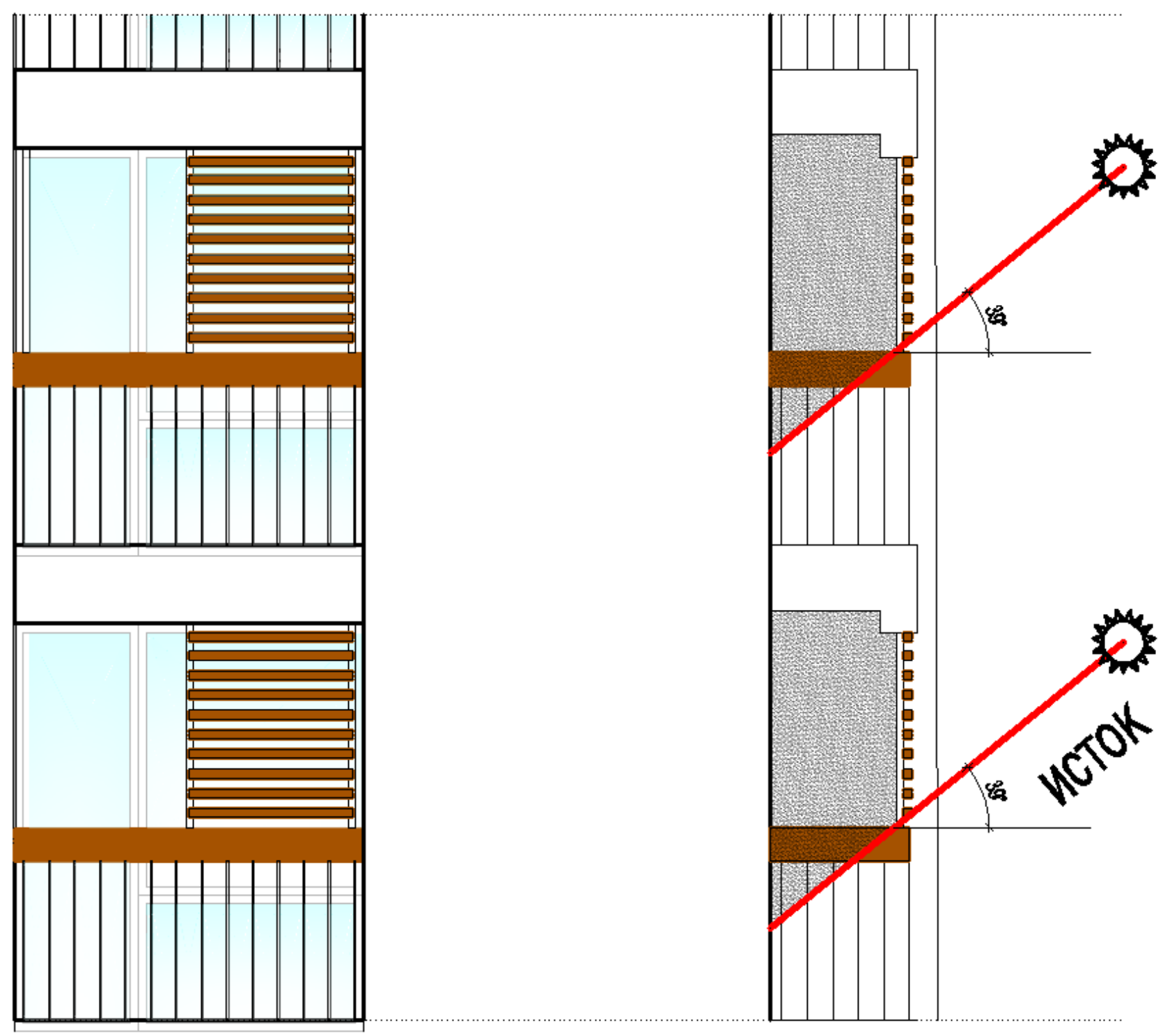

Фигура 94: Засенување на фрасада со помош на перголи (фрагмент југо-исток)

Извор : Катерина Петрушевска

Перголите поставени на балконите се од дрвени елементи, на метална подконструкција монтирана на балконката конзола. Заради атмосферска заштита се обложени со фин алуминиум во дрво боја. На оние места на фасада каде има природна заштита од зеленило, овие елементи не се поставуваат. Повторно заради помала интервенција кај балконската ограда, во монтажата на перголите не е земено во обзир да бидат по цела прозорска висина и предвидени се да овозможат делумно засенување. Прицврстувањето на истите е во балконската конзола во горна зона и ракохватот во долна зона. 


\section{Механичка вентилација}

Обвивката на зградата ќе биде нова, со дебелина на слојот кој ќе овозможи соодветна заштита од одлив на топлинска енергија. Прозорите и вратите на фрасада се предвидуваат да бидат заманети со нови, соодветно монтирани и заптиени кај контактот меѓу рамката и зидот, така што во просториите на станбените единици ќе се создаде температура и влажност на воздух која ќе има потреба од механичка вентилација појаснува Миловановиќ (Milovanovič н.п.). Интегрирање на еден ваков систем налага превземање на студиозни мерки, а финансиски е скап. Предлогот за механичка вентилација во кулата К4 е предвиден да биде со малите системи, приложени во фигура 95. Истите се вградуваат на надворешниод sид во секоја соба, за време на обновата на облогата на фасада. Градежниот зафат се состои од отварање на отвор со $\varnothing$ 100, во зидот. Монтажата е едноставна, не бара додатна интервенција во станбенитте единици, единствено е потребно довод на електрична инсталација до уредот. Позицијата на поставување е на фасаден sид. Овие мали системи се предвидени за станбени згради и претставувааат помала инвестиција, а достапни се и можат да се донесат и за македонски потреби. Конструирани се во развиените земји кои имаат проблеми со појава на мувла во зградите. Претставуваат дополнителен уред кој ги намалува вентилационите топлинските загуби. Уредот внесува нов воздух, го прочистува преку филтри и преработува во собна температура од $21^{\circ} \mathrm{C}$ го изнесува употребениот наизменично во разлика од 1 минута. Работи во тивок мод 24 часа, бидејќи троши мин. ел. енергија од 3W. Во случај на глобално загадување постои можност за заптивање на уредот. Овие податоци се гарантирани од производителот на уредот. Ова претставува предлог размислување за решение на поставување на механичка инсталација. Ова решение од финансиски аспект, би изнесувало 1000-2000€ по стан. Доколку се појави потреба од изведбен проект и реализација на ваков тип на објекти, треба соодветни стручни лица да разгледаат повеќе алтернативни решенија и да се одбере најприфатливото решение за овој случај. 

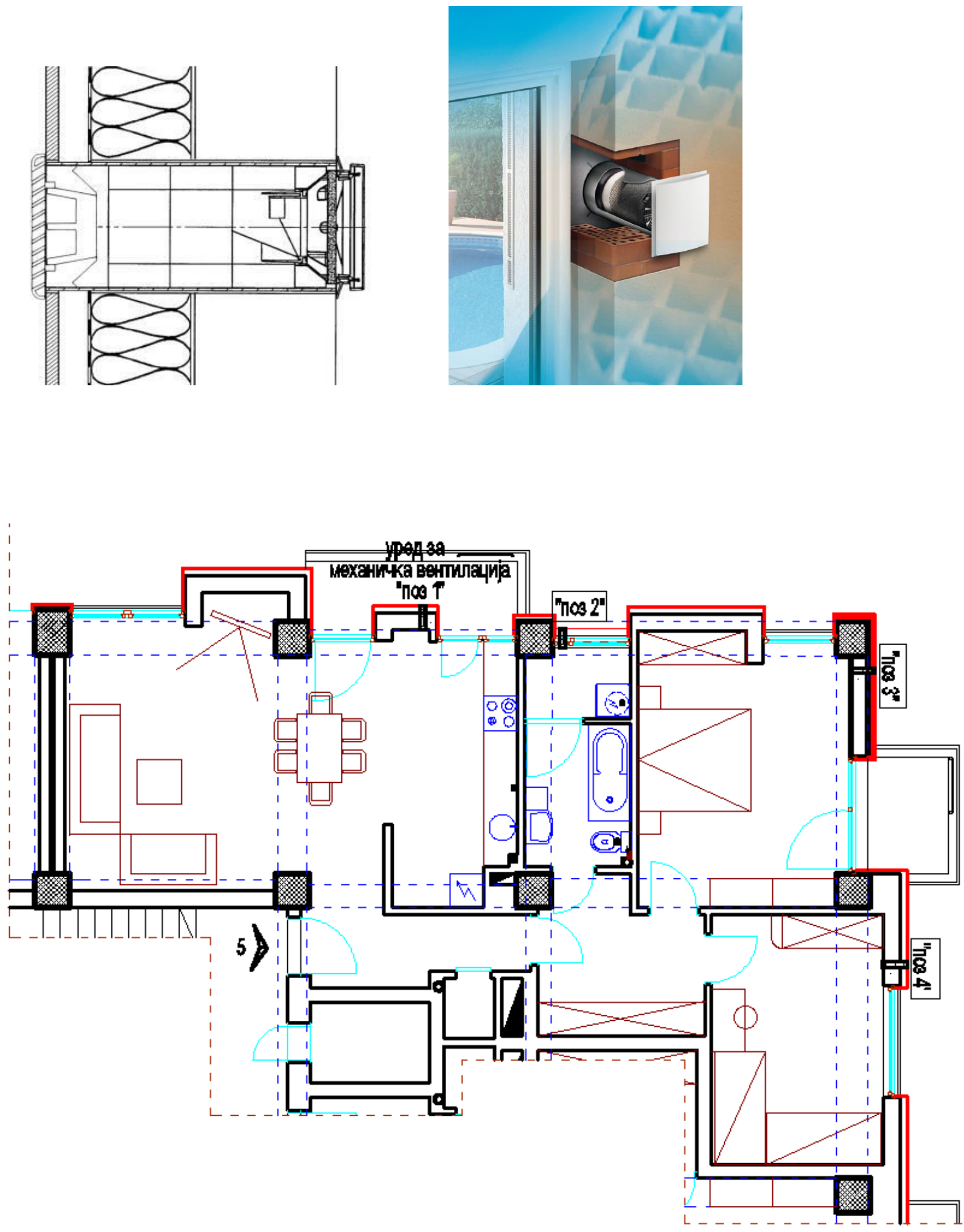

Фигура 95: Механичка вентилација, позиционирање - систем LUNOS Извор: Катерина Петрушевска - Семинар за 2xE (2013) 


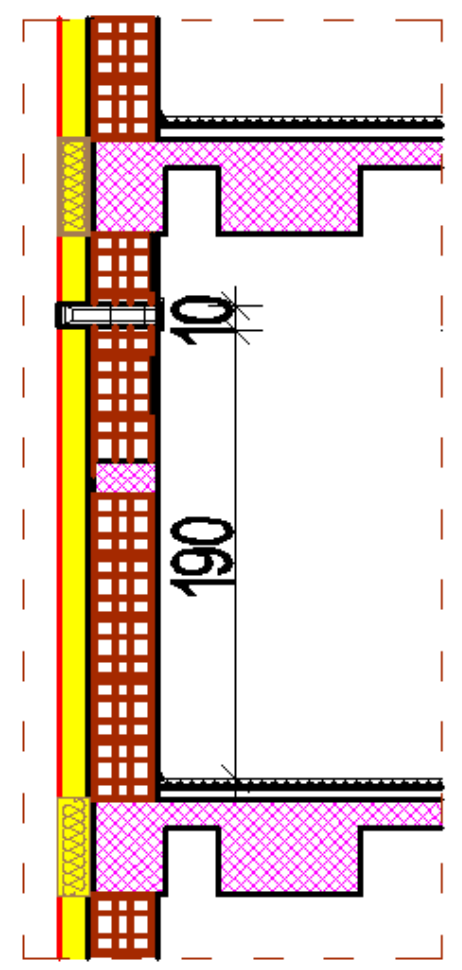

Фигура 96: Механичка вентилација, позиционирање - систем LUNOS Извор: Катерина Петрушевска - Семинар за 2xE (2013)

\section{Заштита од пожар и др. неприлики}

При интегрирање на една нова обвивка на фасада, треба да се превземат и мерки за заштита од пожар, земјотрес, ветрови и сл. Заштитата многу зависи од стручната изведба која ќе функционира на начин каде помали елементи и состави формираат систем. Овој систем е составен од материјали кои мора да бидат потврдени со соодветен сертификат. При создавање на една нова обвивка на фасада од композитни системи за надворешна термичка изолација, системот предвидува противпожарна заштита со примена на метода на вградување на заштитна брана или бандерола за пожар. Пожарот кога настанува во стан, опасноста да премине кон останатите станови е преку прозорците и вратите на фасада. Во трудот како изолација на фасада е применет експандиран полистирен, кој не ги исполнува секогаш, условите за заштита од пожар. Поради тоа на над прозорната греда и над секој отвор се поставува изолација од минерална волна. Но многу поефикасно решение според прирачникот од Павловски (2011) е поставување на бандерола или целосна обиколка од минерална волна над отворите од секој кат. Оваа метода се применува кај згради повисоки од четири спрата, а секако во една ваква изведба треба и да се прегледаат сите противпожарни закони предвидени за 
нашата земја. Обиколната трака од минерална волна е лепена целосно на фасада, по потреба прицврстена со термо типли и минимална висина од $20 \mathrm{~cm}$. Ова решение е практично од причина што може да заштеди време и избегнува комлицирани детални изведби. Од друга страна заради одредени елементи над прозорците (отворите) кои може да станат пречка во изведбата, оваа метода дозволува лепење на минералната волна на растојание од 0-50см од прозорците и вратите на фрасадата.

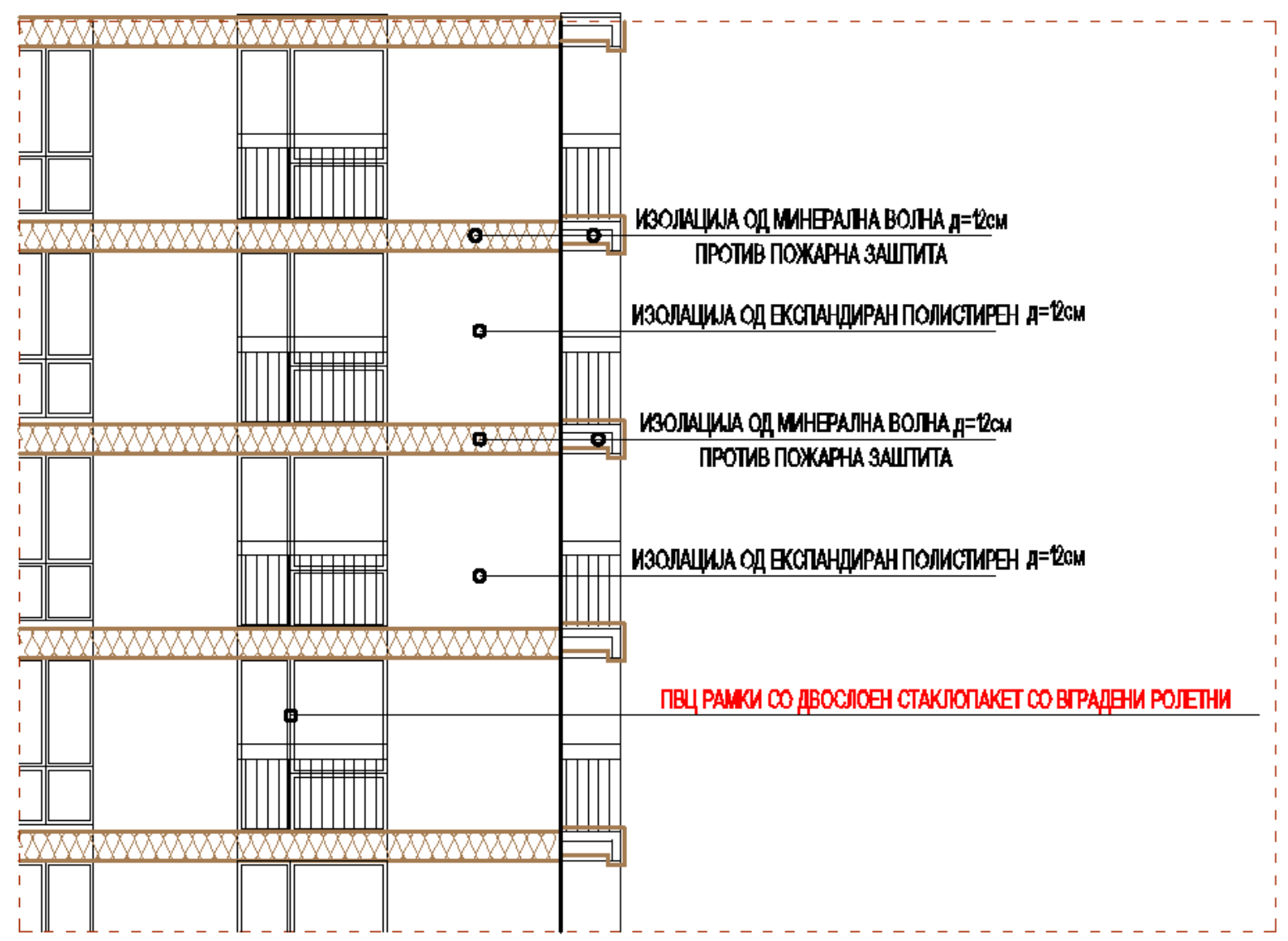

Фигура 97: Заштита од пожар (фрагмент, обработка на фасада) Извор: Катерина Петрушевска

Според Павловски (2011), ова растојание (0-50см) дозволува да се постави на појасот кај меѓукатната конструкција од објектот (фигура: 97). Во случајот на кулата К4 местосто на вградување е на гредите од меѓукатната конструкција кои излегуваат на фрасадата. Производителите на термофасади препорачуваат: При изведба на изолација на фасади, да се прати постоечката дилатацијата кај зидаријата на објектот, а термичките мостови де се избегнуваат со поставување на минерална волна во просторот на дилатациската фуга. На овој начин се запазува и противпожарноста дополнително. 
Од сето горе наведено, се поставува прашањето за изборот на изолацијата и употребата на минерална волна, како материјал каде во некои земји се избегнува во последно време од здраствени причини. Сепак големите компании го негираат ова прашање со испитување и сертификат од страна на светската здравствена организација. Според КОСMO (COSMO 2005:38) - " На состанокот IARC (International Agency for Research on Cancer), одржан од 9-16 октомври 2001год. Во Лион, Франција, минералната волна, а со тоа и камената е класифицирана во група 3, односно како материјал кои не е канцероген". Knauf Roock ја има истата потврда од СЗО.

\section{Боја на фасада и кров}

Бидејќи ориентацијата кај постоечките објекти е еден вид затекната состојба, треба акцентот да се посвети на бојата на фасадата која ја привлекува или одбива сончевата енергија и топлина. Бојата на фасадата ќе биде со светли тонови како не би се прегрејувала во летниот период. Ова е од голема важност за западната и јужната фрасада. Посветено е внимание и на изборот и бојата на покривачот. Според Лехнер (Lechner 2013) - "Белиот кров овозможува 50\% помалку загуби отколку темните бои на покривач. " Кулите се станбени објекти и не се сметаат за споменици на културата, од тука може да се интервенира во поглед на промената на фасадата. Но сепак автентичноста на објектот е задржана, што укажува на добра обликовна вредност на постоечкиот објект. Промената на фрасадата е само во изборот на боите, првенствено од причина што се опшива со термо обвивка армирано бетонската видлива конструкција. На овие места, добиваме основна бела боја. Потенцирањето на вертикалите на фасада останува, но во светли тонови колоритно разбиени. Покрај следењето на современите трендови, улога во изборот на боите има и одбивањето од сончево прегрејување. На еден ваков начин ке бидат постигнати и наметнувањата или освежувањата, предизвикани од постоечкиот Сити Мол и кулата покрај него, како репер точка во овој дел од урбаниот контекст. 


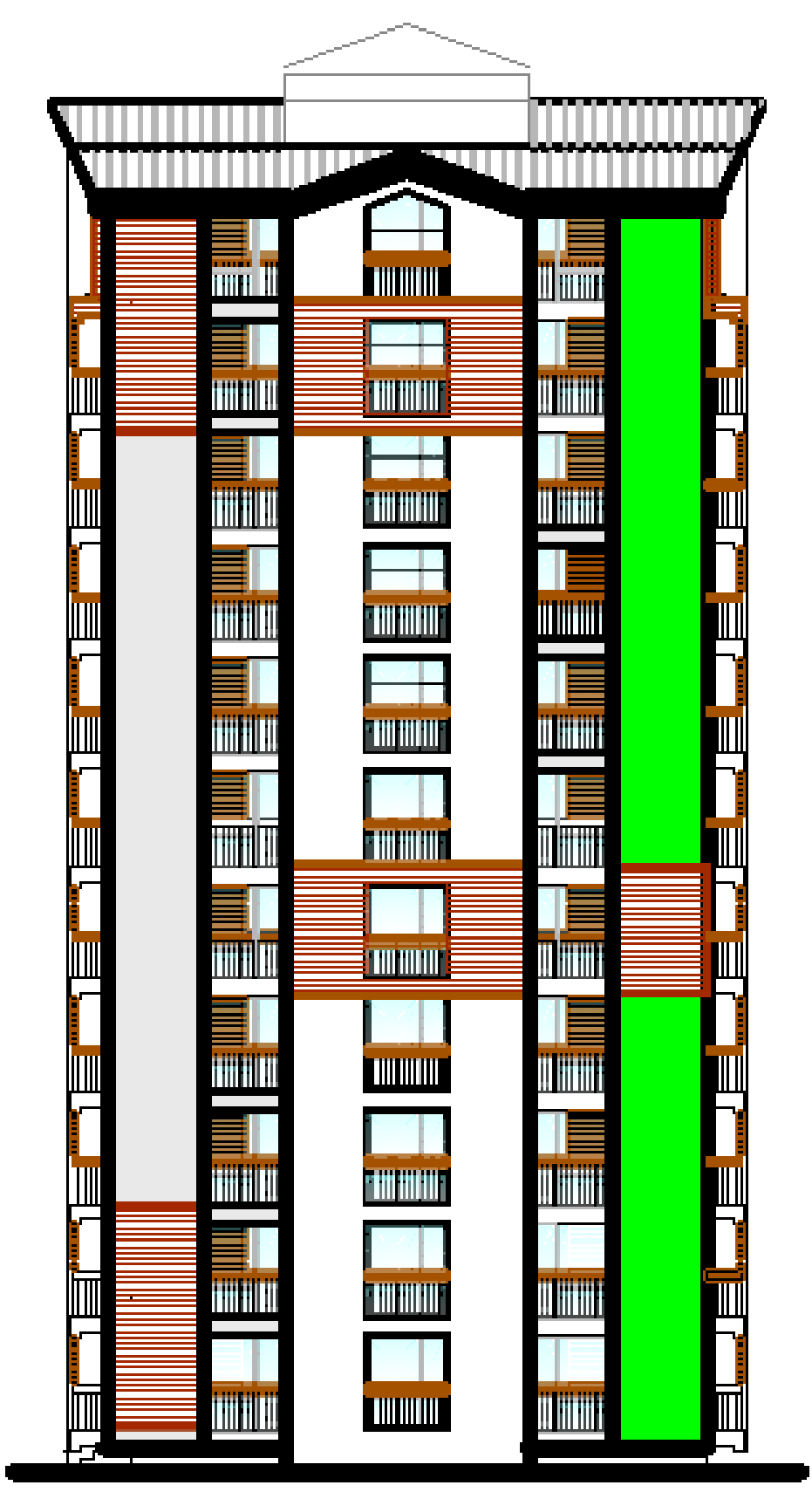

ФACAДHA БOJA HA ЗАBPШEH MATTEP:

фасадна 6оја JUB /ACN 5002 - бөла 6оја G 1.5 JUB 1035*, измазнет малтер, со гранупација 1.5

фасадна боја JUB 4662* - сива 6оја, G 1.5 JUB $1035^{*}$, измазнет малтер, со гранулација 1.5

фасадна 60ја JUB 5630 - зөлена 6оја, G 1.5 JUB $1035^{*}$, измазнет малтер, со гранулација 1.5

фасадна боја 1210 - төракота 6оја, төкстура - Valit JPR 2013* 


\section{Резултати од модернизацијата на кулата К4}

Табела 13: Коефициенти на пренесување на топлина низ градежните материјали

табела U/Umax: Од Прилог бр.3

\begin{tabular}{|c|c|c|c|c|c|}
\hline р.бр & ПОЛОЖБА & ознака & $\begin{array}{c}\mathbf{U} \\
{\left[\left(\mathrm{W} / \mathrm{m}^{2} \mathrm{~K}\right)\right]}\end{array}$ & $\begin{array}{c}\mathbf{U}_{\max } \\
{\left[\left(\mathrm{W} / \mathrm{m}^{2} \mathrm{~K}\right)\right]}\end{array}$ & $\begin{array}{c}\text { Исполенето } \\
\text { ДА / НЕ }\end{array}$ \\
\hline 1 & Надворешен sид - фрасада & HS1 & 0.27 & 0,35 & ДА \\
\hline 2 & $\begin{array}{l}\text { Надворешен зид - фрасаден } \\
\text { - АБ платно }\end{array}$ & HS2 & 0,28 & 0,35 & ДА \\
\hline 3 & $\begin{array}{l}\text { Под (паркет - над негреан } \\
\text { подрум) }\end{array}$ & Д1 & 0,56 & 0,35 & $\mathrm{HE}$ \\
\hline 4 & $\begin{array}{l}\text { Под (плочки - над негреан } \\
\text { подрум) }\end{array}$ & Д2 & 0,59 & 0,35 & $\mathrm{HE}$ \\
\hline 5 & $\begin{array}{l}\text { Топлотен мост кај балконска } \\
\text { конзола }\end{array}$ & $\mathrm{HS}(\mathrm{TM})$ & 0,302 & 0,35 & ДА \\
\hline 6 & Под - под во соба на кат & Д4 & 2,87 & 1,35 & $\mathrm{HE}$ \\
\hline 7 & $\begin{array}{l}\text { Внатрешен преграден sид - } \\
\text { стан - скалишен простор }\end{array}$ & BS1 & 1,41 & 0,35 & $\mathrm{HE}$ \\
\hline 8 & Кров1 & K1 & 0,24 & 0,20 & ДА /HE \\
\hline 9 & Кров2 & K2 & 0,22 & 0,20 & ДА/НЕ \\
\hline
\end{tabular}

Извор: Катерина Петрушевска

Во Табела 13, прикажани се коефициентите на пренесување на топлина $\mathbf{U}$, добиени од новопроектираната состојба, предложените пресметки и материјали со соодветна димензија. Во истата табела направена е компарација за $U$ коефициентот пресметан во елаборатот за градежна фризика во Прилог бр.3 и максималните коефициенти на пренесување на топлина, $\mathbf{U}_{\max }$. Од Правилникот на Општина Карпош (2012), приложен во Прилог бр.4. - Табела 1. Може да се види дека кај одредени градежни елементи и делови од зградата, коефициентот на пренесување на топлина го исполнува барањето од Правилникот на Општина Карпош (2012). Тоа е затоа што е предложена соодветно димензионирана изолација. Градежните елементи кои не ги задоволуваат коефициентите на премин на топлина, имаат пречки од техничка 
природа поради што не може на нив да се интегрира изолација со задоволителна дебелина на слојот. На пример кај подрумските простории пречка е висината на просторијата која треба да се запази. Кај подната конструкција помеѓу греани простори не е изводливо облагањето, а како исклучок би било комплетна реконструкција на стан. Кај скалишното јадро секако сме ограничени со димензиите во просторот. Но сепак, оние позиции кои не ги исполнуваат условите во новопроектираната состојба, подобрувањето со помали интервенции, во однос на постоечката состојба е значително.

Во следната Табела 14, направена е компарација помеѓу составот на материјалите на објектот, пред и после обновата. Потоа приложени се коефициентите на пропусливост на топлина пред и после обновата, споредени со максимално дозволените коефициенти за премин на топлина кои одговараат на денешните услови и потреби за енергетско ефикасни згради.На крајот од табелата 14, дадена е потрошувачката на енергија пред обновата и после обновата каде според таблиците за формирање енергетски пасоши објектот од " D" преминува во "B" категорија со заштеда на енергија за греење од $71 \%$.

Табела 14: Споредбена анализа пред и по предложената модернизација на зградата во Карпош 4 на бул. "Партизански Одреди бр.76"

\begin{tabular}{|c|c|}
\hline Пред модернизација & По предложена модернизација \\
\hline 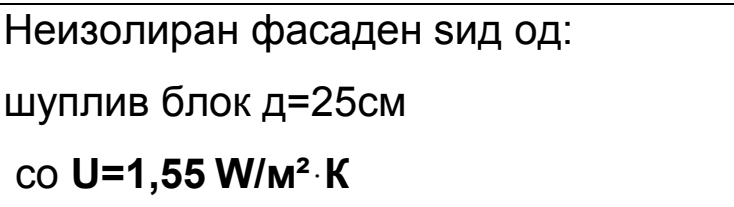 & $\begin{array}{l}\text { Фасадна обвивка изолирана со: } \\
\text { EPS / шуплив блок д=25см } \\
\text { Co U=0,27 W/ } \mathbf{m}^{\mathbf{2}} \cdot \mathbf{K}\end{array}$ \\
\hline $\begin{array}{l}\text { Неизолиран фрасаден зид од: } \\
\text { армирано бетонско платно д = } 20 \text { см } \\
\text { со U =3,43 W/m²· } \\
\text { Големи топлински мостови }\end{array}$ & $\begin{array}{l}\text { Фасадна обвивка изолирана со: EPS / } \\
\text { армирано бетонско платно д = } 20 \text { см } \\
\text { со U =0,28 W/ } \mathbf{m}^{\mathbf{2}} \cdot \mathbf{K}\end{array}$ \\
\hline & $\begin{array}{l}\text { Umax=0,35 W/M².K- Исполнет e } \\
\text { условот за Umax }\end{array}$ \\
\hline
\end{tabular}




\begin{tabular}{|c|c|}
\hline $\begin{array}{l}\text { Под над негреан подрум } \\
\text {-Паркет д=2,4см } \\
\text {-Битуменски премаз } \\
\text {-Армирано бетонска плоча д=12см } \\
\text { со U=1,96 W/m²·K }\end{array}$ & $\begin{array}{l}\text { Под над негреан подрум } \\
\text {-Паркет д=2,4см } \\
\text {-Битуменски премаз } \\
\text {-Армирано бетонска плоча д=12см } \\
\text {-Камена волна д=5см } \\
\text {-заштита од гипс картон } \\
\text { U=0,56W/(м²* } \mathbf{~})\end{array}$ \\
\hline & $\begin{array}{l}\left.\text { Umax=0,35 W/( }{ }^{2 *} K\right) \\
\text { Не е исполнет условот, но е } \\
\text { подобрена состојбата }\end{array}$ \\
\hline $\begin{array}{l}\text { Проодна рамна тераса } \\
\text { (неизолирана и оштетена) } \\
\text { со U=2,58 } \mathbf{W} / \mathbf{m}^{\mathbf{2}} \cdot \mathbf{K}\end{array}$ & $\begin{array}{l}\text { Нова подобрена состојба } \\
\text { преобликувана во покриен и греан } \\
\text { станбен простор }\end{array}$ \\
\hline $\begin{array}{l}\text { Кров кај поткровје } \\
\text { Армирано бетонска коса плоча и слој } \\
\text { од битумен } \\
\text { co U=3,676 W/m²K }\end{array}$ & 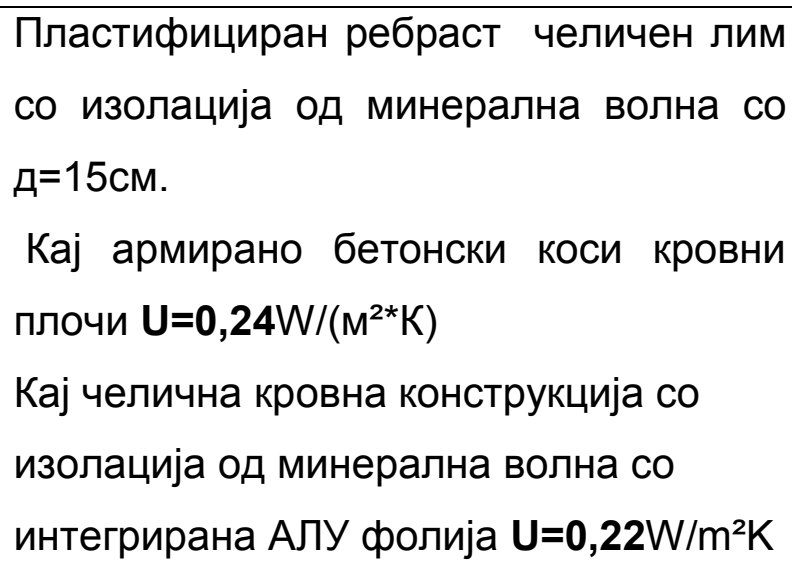 \\
\hline & $\begin{array}{l}\text { Препорака:Со изолација од } 20 \text { см ќе } \\
\text { се задоволи Umax=0,20 W/m² } \mathrm{K}\end{array}$ \\
\hline $\begin{array}{c}\text { Потрошувачка на топлинска } \\
\text { енергија пред обновата } \\
130,76 \mathrm{kWh} / \mathbf{m}^{2} \mathbf{a}\end{array}$ & 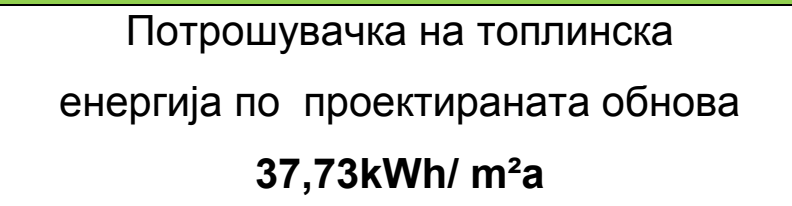 \\
\hline
\end{tabular}

Извор: Катерина Петрушевска

Во Табела 15, прикажани се објектите разгледувани од компаративниот метод со објектот од студија на случај. Приложена е потрошувачката на енергија за греење пред обновата и добиениот резултат од намалената обновена состојба. Направена е компарација помеѓу $U$ коефициентите и дебелината и видот на изолациониот слој. 
Табела 15: Споредбена анализа на резултатите од обновата на два европски примери, еден македонски пример и проектираниот на бул. "Партизански Одреди бр.76"- Карпош, Скопје

\begin{tabular}{|c|c|c|c|c|}
\hline параметри & $\begin{array}{l}\text { Станбена } \\
\text { зграда } \\
\text { Соланова, } \\
\text { Унгарија }\end{array}$ & $\begin{array}{l}\text { Станбена } \\
\text { зграда на ул } \\
\text { Макарт, } \\
\text { Австрија }\end{array}$ & $\begin{array}{l}\text { Станбена } \\
\text { зграда на ул. } \\
\text { Лазар Поп } \\
\text { Трајков бр.34 } \\
\text { Автокоманда, } \\
\text { Македонија }\end{array}$ & $\begin{array}{l}\text { Станбена } \\
\text { зграда на ул. } \\
\text { Партизански } \\
\text { Одреди бр.76 } \\
\text { Карпош } 4 \\
\text { Македонија }\end{array}$ \\
\hline $\begin{array}{l}\text { Потрошувачка } \\
\text { на енергија за } \\
\text { греење на } \\
\text { годишно ниво } \\
\text { Пред обнова }\end{array}$ & $213 \mathrm{kWh} / \mathrm{m}^{2} \mathrm{a}$ & $179 \mathrm{kWh} / \mathrm{m}^{2} \mathrm{a}$ & $277 \mathrm{kWh} / \mathrm{m}^{2} \mathrm{a}$ & $130,76 \mathrm{kWh} / \mathrm{m}^{2} \mathrm{a}$ \\
\hline $\begin{array}{l}\text { Потрошувачка } \\
\text { на енергија за } \\
\text { греење на } \\
\text { годишно ниво } \\
\text { По обновата }\end{array}$ & $29 \mathrm{kWh} / \mathrm{m}^{2} \mathrm{a}$ & $14,4 \mathrm{kWh} / \mathrm{m}^{2} \mathrm{a}$ & $\begin{array}{l}\text { проектирана и } \\
\text { интегрирана } \\
\text { заштеда, но не } \\
\text { е спроведена } \\
120 \text { kWh/m²a }\end{array}$ & 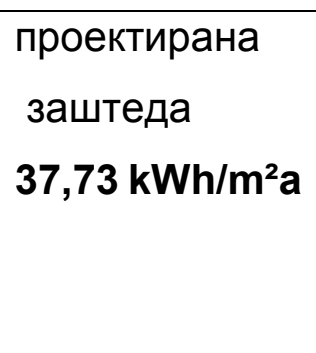 \\
\hline $\begin{array}{l}\text { Неизолирана } \\
\text { фрасада }\end{array}$ & $\begin{array}{l}\mathrm{U}=1,8-2,0 \\
W /\left(\mathrm{M}^{2} \cdot \mathrm{K}\right)\end{array}$ & $\mathrm{U}=1,2 \mathrm{~W} /\left(\mathrm{M}^{2} \cdot \mathrm{K}\right)$ & $\begin{array}{c}\mathrm{U}=1,63 \\
W /\left(M^{2} \cdot K\right)\end{array}$ & $\begin{array}{c}U=1,55-3,43 \\
W /\left(M^{2} \cdot K\right)\end{array}$ \\
\hline Со изолација & $\begin{array}{l}U=0,19 \\
W /\left(M^{2} \cdot K\right)\end{array}$ & $\mathrm{U}=0,21 \mathrm{~W} /\left(\mathrm{M}^{2} \cdot \mathrm{K}\right)$ & $\mathrm{U}=0,28 \mathrm{~W} /\left(\mathrm{M}^{2} \cdot \mathrm{K}\right)$ & $\begin{array}{c}\mathrm{U}=0,27- \\
0,28 \mathrm{~W} /\left(\mathrm{M}^{2} \cdot \mathrm{K}\right)\end{array}$ \\
\hline $\begin{array}{l}\text { Дебелина на } \\
\text { слојот }\end{array}$ & $\begin{array}{l}\text { Изолација } \\
\text { EPS, д=16см }\end{array}$ & $\begin{array}{l}\text { Соларен } \\
\text { панел/4см } \\
\text { камена волна }\end{array}$ & $\begin{array}{l}\text { Изолација } \\
\text { EPS, д=12cм }\end{array}$ & $\begin{array}{l}\text { Изолација } \\
\text { EPS, д=12cм }\end{array}$ \\
\hline
\end{tabular}

Извор: Катерина Петрушевска

Од Табела 15 може да се заклучи дека примерот во студијата на случај е најблиску до примерот "Соланова". 
Според потрошувачката на топлинска енергија на годишно ниво класификацијата во енергетските сертификати е :

Табела 16: Споредбена анализа на дадените примери при енергетско сертифицирање

\begin{tabular}{|c|l|l|l|l|}
\hline & $\begin{array}{l}\text { Обнова на } \\
\text { станбена } \\
\text { зграда }- \\
\text { Соланова, } \\
\text { Унгарија }\end{array}$ & $\begin{array}{l}\text { Станбена } \\
\text { зграда } \\
\text { Австрија }\end{array}$ & $\begin{array}{l}\text { Станбена } \\
\text { зграда - } \\
\text { Автокоманда, } \\
\text { Македонија }\end{array}$ & $\begin{array}{l}\text { Обнова на } \\
\text { станбена } \\
\text { зграда - } \\
\text { Карпош 4 } \\
\text { Македонија }\end{array}$ \\
\hline & $\mathbf{B}$ & $\mathbf{A +}$ & $\mathbf{C}$ & $\mathbf{B}$ \\
\hline
\end{tabular}

Извор: Катерина Петрушевска

Табела 17: Означување на сертификати според потрошувачката на енергија за греење

\begin{tabular}{|c|c|}
\hline Класификација на станбени згради & $\begin{array}{c}\text { Потрошувачка на топлинска } \\
\text { енергија на годишно ниво(kWh/m²a) }\end{array}$ \\
\hline A+ & $\leq 15$ \\
\hline A & $\leq 25$ \\
\hline B & $\leq 50$ \\
\hline C & $\leq 100$ \\
\hline D & $\leq 150$ \\
\hline E & $\leq 200$ \\
\hline F & $\leq 250$ \\
\hline G & $>250$ \\
\hline
\end{tabular}

Извор: Катерина Петрушевска ( По урнек од енергетски сертификат )

Очекувани резултати од проектот и аудитот за енергетско ефикасна модернизација на станбената кула на ул."Партизански Одреди бр.76"

Кулата на ул. " Партизански Одреди"бр.76, во населбата Карпош 4 во Скопје, се вбројува во потенцијалните објекти кои спаѓаат во сценариото за имплементација на европската директива 2010/31/EU. Како објект со потрошувачка од 130,76kWh/m²a на енергија за греење се вбројува во "D" класа во енергетските сертификати. Во поглавието 7 од Магистерскиот труд, планирана е модернизација на објектот со одредени мерки според енергетско 
ефикасни принципи. Главната цел е санација и обнова на кровот и поткровјето, нова обвивка на зграда (по хоризонтала и вертикала). Клучно решение за создавање на енергетско ефикасен објект во овој случај претставува исполнување на условот за максимален коефициент на премин на топлина. Според новопланираниот проект за одредени мерки на подобрување на термоизолацијата се постигнува заштеда од $71 \%$ или намалување на трошоците за енергија за греење. Заштедата изнесува $37,73 \mathrm{kWh} / \mathrm{m}^{2} \mathbf{a}$, што го вреднува објектот во "В" класа од енергетските сертификати кои треба да ги исполнуваат во иднина објектите. На територија на Општина Карпош, според Државниот завод за статистика (2002) од 1971-80 година на градба, постојат вкупно 5332 стана. Моментално кога истите би имале енергетски пасоши, би биле во постоечката "D" класа. Кога би се интегрирале енергетско ефикасни принципи преку модернизација на истите, би можело да има сериозно отскокнување во енергетските сертификати. Тоа подразбира дека во Република Македонија, најранливи објекти кои би можеле да подлежат на модернизација според периодот на градба, се 181969 станови, од податокот од Државниот завод за статистика (2002). Со превземање на одредени мерки на модернизација кај зградите, би добиле сериозен отскок во поглед на исполнувањето на ЕУ регулативите. На овој начин би се одржувала цената на недвижноста. Со еден збор, задоволени се потребите на денешните и идните генерации на корисници на објектот.

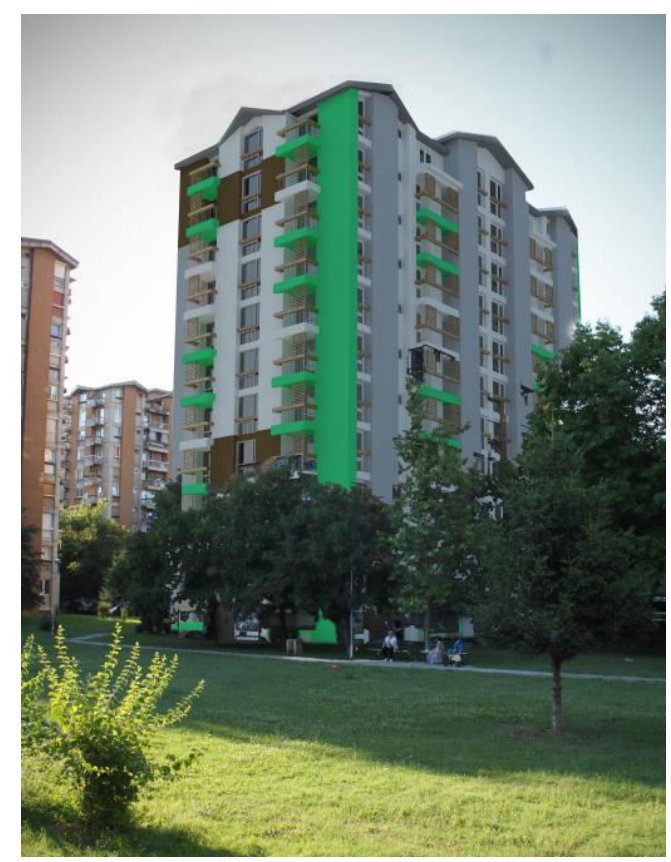




\section{8.Заклучок и препораки}

Во магистерскиот труд, направено е истражување на една повеќесемејна станбена кула, преку модернизација со енергетско ефикасни принципи низ комплетно нова обвивка на истата (по хоризонтала и вертикала). Потточно, преку пример за санација на кровната конструкција, покривачот и поткровјето, како и предлог мерки за санација на фасадната обработка и плафонот под приземјето. Покрај загубата или заштедата на топлинската енергија првенствено, истражувањето ја презентира и состојбата на објектот во услови на изминати четириесетина години по однос на градба и одржување на истата. Во квалитативниот метод на истражување, разгледани се заложбите на светско ниво за имплементација на мерките на модернизација кои пред се треба да резултираат со повратен енергетски бенефит. Претставени се механизмите кои служат за систематско и обврзно залагање за обнова на постоечките станбени згради од страна на европските директиви и законски мерки. Општо е приложено класифицирањето на објектите според одредени перформанси со транспарентно приложување на конзумацијата на енергија преку наметнатите енергетски сертификати. Овој проблем е на глобално ниво со што се овозможува преглед или пасош со кој секој објект ќе биде класифициран по одредена вредност. Ваквиот начин ќе овозможи енергетска контрола, но и мотивирачки тенденции за одржливост во градежништвото и развој на нови професии. Понатаму во трудот претставени се станбените објекти во Р.Македонија низ еден историско-инерпретативен преглед низ изминатите години на развој на државата. Истите во споредба со соседните држави на Балканот и Европскиот Континент, не одстапуваат многу од проблемите создадени низ годините од временски, атмосферски, економски и социјални фрактори. Во теорискиот дел од трудот представена е општата состојба на постоечките згради, потоа енергетско неефикасни згради, оштетување кај постоечки згради како и можни решенија за модернизација на истите. Понатака разгледувани се начините на имплементација на обвивката на зградите која ќе овозможи непречено одвивање на престој во истите, како и заштита на топлински мостови како предизвикувачи на "рани". Ова е од особено значење кај станбените згради, поради непреченото одвивање на животот, што е од голема важност и може да претставува проблем при масовна обнова на истите. 
Во истражувањето кај студијата на случај земени се во предвид сите податоци добиени од квалитативниот и компаративниот метод на истражување. Направен е предлог проект и аудит за обнова на зградата каде крајниот резултат ќе биде компариран со претходно разгледуваните примери од компаративната метода на истражување. Пред се̉, направена е анализа за состојбата или преглед на станбената зграда од аспект на градежните конструкции, инсталации и оштетувања од влага. Секако дека не е исклучена и критичната мисла од страна на сопствениците на станови, како и апсолвирање на моменталните и идни проблеми на станбената кула. Од тука се предлага да при планирана реализација на ваков тип на обнова, би требало да се одстранат и санираат проблемите предизвикани од влага и останати оштетувања доколку постојат. Пред секое превземање на градежни мерки за обнова на зграда по енергетско ефрикасен концепт, потребно е да се предложи проект со разработени детали и обврзно енергетски елаборат, за да се согледа потрошувачката на енергија (во случајов топлинска) на зградата. Со таков еден систематски пристап се добива реалната енергетска состојба од каде што во зависност од економските вложувања и тенденции за подобрувањето, може да се предвиди енергетско ефикасна модернизација. Во студијата на случај направено е предлог решение за нова обвивка на зградата која ќе резултира со термичка заштеда од 71\%. Во пресметките, задоволени се локалните барања за максимален коефициент на топлинска пропусливост за одредени градежни конструкции. Оние кои не ги исполнуваат условите од техничка природа, се подобрени за одредени мерки, но не во целост. Идеата е да се превземат економични мерки, а истите вродат со резултат. Целта е да се постигне заштеда која при можна реализација би го класифицирала објектот на задоволително ниво. Во теоретски, проектираниот случај од "D" преминува во "В" класификација. Покрај тоа, овозможено е зголемување на квалитетот на станбениот простор на поткровјето. Може да се заклучи дека со превземање на само одредени проектирани мерки се постигнува резултат близок до европските примери и дека ваквиот резултат вродува со плод - во случајов енергетско ефикасен објект. Од тука може да се потенцира дека, за да се намали енергијата за греење од $130,76 \mathrm{kWh} / \mathrm{m}^{2}$ a на $37,73 \mathrm{kWh} / \mathrm{m}^{2}$ а или да се отскокне во "В" класификација на енергетски пасош, во овој тип на станбени објекти превземени се следните проектирани мерки: енергетска контрола на 
постоечката состојба со пресметка на потрошувачката на топлинска енергија и предложени решенија со проект за обнова. Клучни фрактори кои ќе влијаат на новиот енергетско ефикасен објект се: добро заптиена и соодветна обвивка на зграда, која покрај изолацискиот слој, вклучува замена на нови прозорски елементи соодветно монтирани. Избегнување на топлински мостови, покривање и изолирање на поткровјето и вградување на механичка вентилација. Покрај тоа се јавува потреба од инструмент кој ќе овозможи насочување на станарите за запознавање со состојбата за можна реализација на обнова на зградата и дополнителна едукација за енергетско ефикасна култура. Конечниот заклучок од овој труд е дека станбените објекти во Република Македонија од "најранливата" категорија, бројат 181969 стана, според Државниот статистички завод (2002). Кога истите би се модернизирале за одредени мерки според енергетско ефикасни принципи би добиле голем отскок во класифицирањето кај енергетската сертификација и приближување кон ЕУ регулативите. Препораката во овој истражувачки труд е да при ваков тип на реконструкции се оформи процес на постреконструктивна евалуација каде ќe ce следат резултатите, заштедите и формираат насокоите. На ваков начин би се потврдувале или корегирале методологиите во интегрирање на енергетско ефикасни мерки. Овој вид на пристап на истражување овозможува формирање на нови идеи за одржливост на градежните објекти и нуди можни решенија за останатите истородни станбени објекти. Формира развој на информации кои стручната јавност може да ги разработува, каталогизира и евидентира, а со тоа ќе се овозможат нови работни места, подигнување на културното ниво на жителите на градот како и создавање иднина на семејствата кои ќе бидат наследници на постоечките станбени згради. Потенцирана е улогата на архитектот при ваков вид обнова како главна улога во зачувување или продолжување на архитектонскиот современ израз. Проценката за заштитата или реобновата на фасада по архитектонски принципи не смее да биде наметната од други надворешни влијанија. Зградите како носители на културната и социјалната состојба на едно општество, треба да се третирани одговорно од сите инволвирани структури во процесот на одржување на животниот век и квалитетот на живеење во истите. 


\section{Референци:}

1. ARCH + MORE, (2007). Renovation up to passive house standard - LINZ Makartstase. [online] Giwog, ARCH + MORE, gapsolar.

Достапно на:

< http: www. ei-

education.aarch.dk/fileadmin/filer/.../IDM_presentation150sw.pdf

[Пристапено 10 јануари, 2013]

2. Aschauer, J. (2006) Passive house retrofitting of an apartment building. [online] Linz: gap-solar GmbH.

Достапно на:

< http: www.aee-intec.at/Ouploads/dateien328.pdf

[Пристапено 10 јануари, 2013]

3. Banfi,S;Farsi, M;Filippini,M;Jacob,M.(2008) Willingess to pay energy-saving measures in residential buildings. [online] *Centre for energy policy and economics, Department of Menagment Technology and Economics, ETH Zurich, Zürichbergstr.18, CH-8032 Züich, Switzerland. *Department of Economics, University of Lugano, Lugano, Switzerland.

Достапно на: www.sciencedirect.com/science/article/pii/S0140988306000764

[Пристапено 15 септември, 2013]

4. Bašič et al. (2008) Modul 12 - Upravljanje potrošnjom, štednja energije i obnovljivi izvori energije. [online] Vlada na Republika Srpska Достапно на: < http: www.vladars.net/.../ESSBIH_Modul\%2012.p...

[Пристапено 13 февруари, 2014]

5. BPIE (2013) a guide to developing strategies for building energy renovation [online] Buildings Performance Institute Europe - BPIE Достапно на:

www.bpie.eu/.../BPIE/Developing_Building_Renovation_Strategies.pdf

[Пристапено 13 февруари, 2014]

6. Borkovič, Z. (2012). Energetska Certifikacija I Potencijal Energetske Obnove Zgrada u RH. [online] . Загреб: ElHP.

Достапно на:

< http:www.supeus.hr/.../Seminar_Supeus_EIHP_Zeljka_Hrs_Bork..

[Пристапено 10 декември, 2012]

7. Borkovič, Т. (н.п.) Потенцијал енергетске обнове постојечих зграда.

[online] Zagreb: Energetski institut Hrvoje Požar.

Достапно на:

<http: www. huec.hr/.../7.POTENCIJAL\%20ENERGETSKE\%200...

[Пристапено 20 февруари, 2013] 
8. Bukarica, V. (2012) Vodic za izradu I provedbu politike energetske ucinkovitosti tuzlanskog kantona. [online] NERDA.

Достапно на : < http: //www.vladatk.kim.ba/EnergetskaEfikasnost/Vodic_za_...

[Пристапено 10 мај, 2013]

9. COSMO (2007) Енергетски ефикасни згради. Скопје, COSMO Trade Center - Скопје.

10. Darby, S. (2006) The effectiveness of feedback on energy consumption. [online] Environmental Change Institute, University of Oxford. Достапно на: < http: www. Eci.ox.ac.uk/research/energy/downloads/smartmetering report.pdf.

[Пристапено 15 септември, 2013]

11. EST (н.п.) Trigger points: a convenient truth. Promoting energy efficiency in the home. [online] The Energy Saving Trust's report.

Достапно на:

<http: www.energysavingtrust.org.uk/.../EST+Trigger+Points+report.pdf

[Пристапено 15 декември, 2012]

12. European Council for an Energy Efficient Economy, (2010). The Energy Performance of Buildings Directive ( 2010/31/EU). Eceee policy brief. Достапно на: <http:

www.eceee.org/buildings/eceee_buildings_policybrief2010_rev.pdf

[Пристапено 15 октомври, 2013]

13. European Parliament and council (2010). Directive (2010/31/EU) on the energy performance of buildings (recast). official Journal of the European Union.

Достапно на:

<http:www. eur-lex.europa.eu/LexUriServ/LexUriServ.do?uri=OJ:L:2010:153...

[Пристапено 15 октомври, 2013]

14. European Commission ( н.п.) low energy buildings in europe: current state of play, definitions and ... [online] - European Commission.

Достапно на: < http:ec.europa.eu/energy/.../buildings/info_note.pd...

[Пристапено 13 февруари, 2013]

15. Feist.W (2010) Short Documentations of Advanced Housing Renovation Projects.

[ online ] Passive House Institute, Darmstat.

Достапно на: < http:

www.passiv.de/old/04.../PHI_IEA37_alle_Projektdokus_mitDeckblatt.pdf

[Пристапено 13 февруари, 2013]

16. Friends of the Earth. (н.п.) Earth Summit - from Rio to Johannesburg. [online] Достапно на: < http: // www.foe.co.uk/resource/briefings/earth_summit.pdf 
17.GGGC (н.п) WHAT IS A GREEN BUILDING?: Fundamental Principles of Green ...[online] Governars Green Government Council.

Достапно на: < http: // www.epa.gov/.../12_8_what_is_green_GGGC.

[Пристапено 13 фоевруари, 2013]

18. Gradjevinar ( 2012) - Енергетска учинковитост у зградарству.

Конференција у обртничкој комори. Граџевинар, 64(2012)2, стр.172.

[Пристапено јануари,2013]

19. Habitat (2010) Residential building Lazar Poptrajkov 34 Skopje, Macedonia. Хабитат, Скопје

20. Habitat (2013) Презентација на неделата на енергетска ефикасност, 25-29 noemvri. Општина Карпош, Скопје

21. Han, D. (2012) Concise Environmental Engineering. [online] Ventus Publishing ApS ISBN 978-87-403-01977

Достапно на : < http: // www.bookboon.com/en/concise-environmentalengineering-ebook

[Пристапено 15 септември, 2013]

22. Hazucha, J. (2010) Obnova zgrada socijalnog stanovanja - PASS -NET, Smjernice za obnovu komleksa. [online] Inteligent Energy Europe.

Достапно на: < http: www.pass-net.net/.../pdf/situation_croation-version.pd...

[Пристапено 20 јануари, 2013]

23. Hensen, J. et al. (2004) Building Performance Simulation for better design:some issues and solutions. [online] Einthoven: Technische Universiteit Eindhoven, Netherlands Достапно на: < http: www.bwk.tue.nl/bps/Hensen/publications/04_plea_bpsissues.pdf.

[Пристапено 19 септември, 2013]

24. Hermelink, A. (2005) SOLANOVA - "Factor 10"-retrofit Of large Residential ECEEE. [online] еceee.org. Достапно на:

$<$ http:www.eceee.org/conference_proceedings/eceee/2005c/Panel_2/.../paper www.eceee.org/library/conference_proceedings/.../2136hermelink

[Пристапено 15 февруари, 2014]

25. Hermelink, A. (2007) Solanova Presentation in Brussels. [online] University of Kassel.

Достапно на < http:

www.solanova.org/.../SOLANOVA_Presentation_Brussels_02-2007_Herme...

[Пристапено 28 ноември, 2013]

26. Howe, С.(н.п.) Overview of Green Buildings.[online] by JC Howe Достапно на < http: www.sallan.org/pdf-docs/CHOWE_GreenBuildLaw.pdf

[Пристапено 13фревруари, 2013] 
27. IEE, ( н.п.). Energetska svojstva zgrada - recnik poimova. [ online ] Inteligent Energy Europe.

Достапно на:

<http: www.intense-energy.eu/.../INTENSE_Glossary_EN-H...

[Пристапено 15 декември, 2012]

28. Inteligent Energy Europe, 2013. Build up skills - energy training for builders. [online] Brssels: European Commission.

Достапно на: < http: www pvcert.gr/assets/media/PDF/news/339.pdf ...

[Пристапено 8 јануари, 2013]

29. Kaufmann, B. (2010). Short Documentations of Advanced Housing Renovation Projects. [ online ] Passive House Institute, Darmstat.

Достапно на:

<http: www.passiv.de/.../IEAT37/PHI_IEA37_alle_Projektdokus_mitDeckb...

[Пристапено 14фревруари, 2013]

30. Kaufmann, B. (н.п.) Passive Houses: technology, market, and policy in Europe. [online] Passive House Institute, Darmstat.

Достапно на:

<http:

www.made.org.uk/.../100929_MADE_DA_PassiveHouses_basics_BK.pd...

[Пристапено 10 февруари, 2013]

31. Knezevic, A.; Borkovic, Z., (2009). Primjeri provedenih energetskih pregleda u $R H$. [ online ] Сараево: EIHP.

Достапно на : < http: // www.energetska-efikasnost.ba/Projekt/.../EIHP4.p...

[Пристапено 25 јануари,2013]

32. Knauf Insulation (н.п.) zolacija kosih krovova i potkrovlja [online]- Knauf Insulation

Достапно на : < http: //www.knaufinsulation.hr/../ka-POTKROVLJE-i-KOSI..

[Пристапено 14 февруари, 2013]

33. Lechner, N. (2013) Daylighting and Electric Lighting; Solar Responsive Design - pick the low hanging fruit first. Professor Emeritus\&Architect-College of Architecture, Design and Construction-Ouburn, Alabama,USA. Trudovi od odrzan seminar za EE-Skopje, Macedonija 28 maj,2013.

34. Lombard et al.(2007) A review on buildings energy consumption information. [online] *Grupo de Termotecnia, Escuela Superior de Ingenieros, Universidad de Sevilla, Spain. Sustainable Energy Centre, BRE, Watford, United Kingdom. Достапно на:

<http: www.sciencedirect.com/science/article/pii/S0378778807001016

[Пристапено 15 септември, 2013]

35. LUWOGE, (н.п.) the 3- litre house in Ludwigshafen's Brunk Quarter. [online ] Luwoge, BASF group.

Достапно на:

<http: www.rizakos.gr/docs/3lh_e.pdH

[Пристапено 15 декември, 2012] 
36. Magash, О. (н.п.) Osnove Gradzevinske Fizike. [online] Загреб: Свеучилиште у Загребу.

Достапно на : < http: // www.gradri.uniri.hr/.../GRAĐEVINSKA\%20FIZIKA....

[Пристапено јануари,2013]

37. Milovanovic, В. (н.п.) Toplinska ovojnica zgrade - problem I reshenja u praksi. [online] Загреб: Завод за материјале, Граџевински фракултет Свеучилишта у Загребу.

Достапно на : < http://www.bib.irb.hr/.../597072.Toplinska_ovojnica_zgrade_...

[Пристапено 28 ноември, 2013]

38. Ministarstva graditeljstva I prostornog uredzenja, (2012). Metodologija provodzenja energetskog pregleda gradzevina. [online] MGIPU-RH. Достапно на: < http: www.mgipu.hr/.../Metodologija_provodenja_epg.......

[Пристапено 22 јануари, 2013]

39. Morvaj, Z. et al., 2010. Prirucnik za provedbu energetskih pregleda zgrada. [online] Загреб: UNDP.

Достапно на : < http: // www.zgh.hr/UserDocs/mages/.../auditprirucnik.pd...

[Пристапено 25 јануари,2013]

40. NREL(2006) Zero Energy Buildings: A Critical Look at the Definition ... - NREL Достапно на: < http: www.nrel.gov/docs/fy06osti/39833.pdf

[Пристапено 13 февруари, 2013]

41. NedZink (н.п) Technical instruction handbook [online] NedZink Handbook w Достапно на: < http: ww.sigzincandcopper.co.uk/wpcontent/.../NedZink_Handbook.pdf

[Пристапено 16 февруари, 2013]

42. Proaktiva, (2007). Прирачник за енергетска ефрикасност. [online] Скопје: Проактива

Достапно на < http: www.proaktiva.org.mk/.../MKD_SPARE\%20PRIR...

[Пристапено 25 јануари, 2013]

43. Recknagel-Sprenger (1982) Prirucnik za Grejanje I Klimatizaciju. IRO Beograd,Gradjevinska Kniga.

44. Republika Srbija-Ministarstvo zivotne sredine, rudarstva I prostornog planiranja. 2011. PRAVILNIK O ENERGETSKOJ EFIKASNOSTI ZGRADA. [ online ] Белград: Сектор за граџевинарство и инвестиционе пројекте. Достапно на: < http: // www.eevrbas.org/zakonska-regulative-ee?...pravilnik-....

[Пристапено 28 ноември, 2013]

45. Shkoro, N. 2010. Toplinska zastita zgrada. [online] Загреб: Министарство заштите околиша, просторног уреџења и градитељства. Достапно на : <http://www.hok.hr/.../08\%20Nada\%20Mardjetko\%20Skoro...

[Пристапено 28 ноември,2013] 
46. Sodagar, B. (2013) Sustainability Potentials of Housing Refurbishment. [online] School of Architecture, University of Lincoln, Brayford Campus, Lincoln. Достапно на: < http: // www.mdpi.com/2075-5309/31/278

[Пристапено 19 септември, 2013]

47. Solartopo (2014) Solar calculations with topographics [ online ] Достапно на: < http: // www.solartopo.com

[Пристапено 25 јануари, 2014]

48. United Nations Sustainable Development, (1992) United Nations Coference on Environment \& Development - Agenda 21. [online] Brazil: United Nations. Достапно на:< http: www.sustainabledevelopment.un.org/content/documents/Agenda21.pdf

[Пристапено 12 декември, 2012]

49.USEPA (1991) Sick Building Syndrome [onlineUS Environmental Protection Agency. Достапно на: < http: //www.epa.gov/iaq/pubs/sbs.html

[Пристапено 21 ноември, 2013]

50. Vestel (н.п.) Градежна активност - Животот во Скопје 1918-1941 [online] - vestel Достапно на: < http: www.staroskopje.vestel.com.mk/sites/c06/c06gradezna... [Пристапено 16 февруари, 2013]

51. Vrancic, T. (2012) Energetska ucinkovitost u zgradarstvu. [online] Загреб: Обртничка комора. Достапно на: < http: www.casopis-gradjevinar.hr/.../2012-2prilog-4-ko...

[Пристапено 28 ноември, 2013]

52. Австриска Развојна Кооперација и Програмата за Обединетите нации и др.(2011) Енергетска ефикасност во јавните објекти. Скопје, Министерство за животна средина и просторно планирање.

53.Грабријан, Д.(1986) Мекедонска куќа или преод од стара ориенталска во современа европска куќа. Мисла Скопје, Нип Нова Македонија.

54. Димитрова, М. (н.п.). Македонија кон европска стратегија за енергетска ефикасност. [online] Скопје: evrodijalog.eu.

Достапно на: < http: www.evrodijalog.eu/pdf/.../ED09\%20[115-132].pdf

[Пристапено 13 ноември, 2012]

55.Државен завод за статистика (2011) Одржлив Развој 2011 [online] Државен завод за статистика.

Достапно на: < http: www.stat.gov.mk/PrikaziPublikacija.aspx?id=47..

[Пристапено 13 февруари, 2013] 
56.Државен завод за статистика (2002) Станови, Згради и Домаќинства [online] Државен завод за статистика.Достапно на: < http: http://www.stat.gov.mk/Publikacii/knigalll.pdf

[Пристапено 16 февруари, 2013]

57. Логинг Електоникс (2013) Примена на Термовизијата за испитување на ефикасност на градежните елементи. Недела на енергетска ефрикасност.Скопје, Логинг електроникс.

58. Македонски центар за европско образование, (2010). Енергетска ефрикасност и EУ. [ online] Скопје: Фондација Институт отворено општество. Достапно на:<http:// www.soros.org.mk/.../energetska-efikasnosti-EU-za-web.pd...

[Пристапено 06 ноември, 2012]

59. Николовски, П. ; Костадиновски, Т. (2010) Стаклото во фрункција на енергетската ефикасност на зградите. Скопје, Конструктор Дооел.

60. Николовски, П. (2011) Семинар за енергетска ефикасност. Трудови од одржан семинар во Стопанска Комора на Македонија. Скопје, Стопанска Комора на Македонија.

61. Николовски, П. ; ААМ (2012) Енергетска ефикасност. Скопје, Министерство за животна средина и просторно планирање на Република Македонија.

62. Николовски, П. (2012) Топлински мостови во градежните конструкции. Скопје, Институт за стандардизација на Република Македонија.

63. Николовски, П. (2005) Прирачник за топлинска заштита на градежни објекти - енергетски ефрикасни згради. Скопје, ААМ.

64. Одделение за енергетска ефикасност на ОК. 2012. Проекти од програмата за енергетска ефрикасност на Опитина Карпош 200820122. [online] Скопје: Општина Карпош. Достапно на: < http: www.slideshare.net/.../20082012-14970226

[Пристапено 10 мај, 2013]

65. Одделение за енергетска ефикасност на ОК. 2012. Презентација: Проекти од програмата за енергетска ефикасност на Општина Карпош за 2008-2012 година. [online] Скопје: Општина Карпош. Достапно на: < http: www.karpos.gov.mk/index.php?option...

[Пристапено 10 мај, 2013] 
66. Општина Карпош (2012) Правилник за Енергетска ефикасност кои треба да ги исполнат проектите за градба на нови и реконструкција на постоечки објекти как услов за добивање на одобрение за градење од Опшина Карпош. Скопје, Општина Карпош.

67. Павловски, Н. (2011) Прирачник за проектирање и изведување на композитни системи за надворешна термичка изолација. Вилах, Комора на овластени архитекти и инжењери на Македонија.

68. Порта 3 (2010) Пилот проект на УСАИД и Хабитат Македонија за енергетска ефикасност. Порта 3, Петок Ноември 18 2011,стр.20-21.

69. Пресинг (2013) Правилник за енергетски карактеристики на зградите. Пресинг , бр.16 / август / 2013,стр.50-55.

70. Спасиќ, С. (2010) Енергетски ефрикасни згради. Скопје, Ив - Дизајн.

71. Службен весник на Р.М. (2011) Закон за градење. Скопје, ЈП Службен весник на Република Македонија.

72. Службен весник на Р.М. (2011а) Закон за енергетика. Скопје, ЈП Службен весник на Република Македонија.

73. Службен весник на Р.М. (2006/2008/20011б) Закон за градежни производи. Скопје, ЈП Службен весник на Република Македонија.

74. Центар за истражување и креирање политики (2013) Поттикнување на енергетската ефикасност: како можат да придонесат локалните заедници? Скопје, Фондација Конрад Аденауер во Република Македонија, Германско друштво за меѓународна соработка, Центар за истражување и креираер политики

75. Штрбац, Ж. (2011) Енергетска ефикасност зграда - енергетска сертификација. [online] Issuu publish, Универзитет Нови Сад. Достапно на : <http:// issuu.com/.../diplomski_master_rad__energetska_efi... 


\section{ПРИЛОЗИ}

\section{пРИлог бр.1}

\section{1. Градежна физика}

Делот од фризиката кој се однесува на топлината и преминот на истата низ градежните материјали е научна дисциплина која се нарекува градежна физика. Топлината како физичка глемина се пренесува на три начини.

- Пренесување на топлината со кондукција ( директно пренесување)

- Пренесување на топлината со конвекција ( индиректно пренесување)

- Пренесување на топлината со радијација ( зрачење)

Во градежните објекти важи фризичката законитост дека температурата во просториите ако е поголема од температурата во надворешната средина (зимно време) се случува премин на топлина од внатре кон надвор. Спротивно на ова во лето топлинскиот проток е во обратна насока. Доброто познавање на физичките својства на материјалите се од битно значење за енергетски ефикасна градба. 


\section{ПРИЛОГ бр.2}

\section{Елаборт за Енергетска Ефикасност}

според предлог Правилник на Општина Карпош

(преглед на состојбата на постоечката кула К4)

ПРЕСМЕТКИТЕ СЕ ПРАВЕНИ СПОРЕД

ПРАВИЛНИК ЗА ЕНЕРГЕТСКА ЕФИКАСНОСТ

НА ОПШТИНА КАРПОШ И ВО НЕГО СПОМЕНАТИТЕ СТАНДАРДИ

ПРЕД РЕКОНСТРУКЦИЈА - ПОСТОЕЧКА СОСТОЈБА

\section{1. ПРОЕКТНИ ПАРАМЕТРИ}

Надворешни проектни параметри:

-во зима : Температура

$-15^{\circ} \mathrm{C}$

-во лето: Температура

$+35^{\circ} \mathrm{C}$

Внатрешни проектни услови:

-во зима : Температура

$+20^{\circ} \mathrm{C}$

-во лето: Температура

$+26{ }^{\circ} \mathrm{C}$

-степен ден *

$\mathrm{DD}=2600$

2.КОРИСНА ПОВРШИНА НА ЗГРАДАТА *

$$
\begin{aligned}
& A n=3192 \mathrm{M} 2 \\
& A=4466.79 \mathrm{M} 2 \\
& V=8487 \mathrm{~m} 3 \\
& \mathrm{Ve}=10609 \mathrm{M} 3
\end{aligned}
$$

3.ОБВИВКА НА ЗГРАДАТА*

4.НЕТО ГРЕАН ВОЛУМЕН НА ЗГРАДАТА*

5.БРУТО ГРЕАН ВОЛУМЕН НА ЗГРАДА*

6.ФАКТОР ФОРМА НА ЗГРАДАТА

fo $=A / V e=3215 / 10609=0.30$

7.ПРЕСМЕТКА НА КОЕФИЦИЕНТИ НА ПРЕНЕСУВАҢЕ НА ТОПЛИНА Ч ЗА СИТЕ ГРАДЕЖНИ КОНСТРУКЦИИ 
Вкупно,табела U/Umax:

\begin{tabular}{|c|c|c|c|c|c|}
\hline p.бp & ПОЛОЖБА & ознака & $\begin{array}{c}\mathbf{U} \\
{\left[\left(\mathrm{W} / \mathrm{m}^{2} \mathrm{~K}\right)\right]}\end{array}$ & $\begin{array}{c}\mathbf{U}_{\max } \\
{\left[\left(\mathrm{W} / \mathrm{m}^{2} \mathrm{~K}\right)\right]}\end{array}$ & $\begin{array}{c}\text { Исполенето } \\
\text { ДА / НЕ }\end{array}$ \\
\hline 1 & Надворешен sид - фасада & HS1 & 1,55 & 0,35 & $\mathrm{HE}$ \\
\hline 2 & $\begin{array}{l}\text { Надворешен sид - фрасаден } \\
\text { - АБ платно }\end{array}$ & HS2 & 3,43 & 0,35 & $\mathrm{HE}$ \\
\hline 3 & $\begin{array}{l}\text { Под (паркет - над негреан } \\
\text { подрум) }\end{array}$ & Д1 & 1,96 & 0,35 & $\mathrm{HE}$ \\
\hline 4 & $\begin{array}{l}\text { Под (плочки - над негреан } \\
\text { подрум) }\end{array}$ & Д2 & 2,37 & 0,35 & $\mathrm{HE}$ \\
\hline 5 & $\begin{array}{l}\text { Топлотен мост кај } \\
\text { балконска конзола } \\
\text { ( површински) }\end{array}$ & HS(T.M.) & 0,49 & 0,35 & $\mathrm{HE}$ \\
\hline 6 & Под - под во соба на кат & Д4 & 2,87 & 1,35 & $\mathrm{HE}$ \\
\hline 7 & $\begin{array}{l}\text { Внатрешен преграден sид - } \\
\text { стан - скалишен простор }\end{array}$ & BS1 & 1,41 & 0,35 & $\mathrm{HE}$ \\
\hline 8 & Проодна тераса & T1 & 2,58 & 0,20 & $\mathrm{HE}$ \\
\hline 9 & Кров & K1 & 3,67 & 0,20 & $\mathrm{HE}$ \\
\hline
\end{tabular}


7.1 Парцијална пресметка на коефициенти на пренесување на топлина $\mathbf{U}$ $3 a$ сите постоечки градежни конструкции.

\section{HS1}

\begin{tabular}{|l|l|l|l|l|}
\hline p.бр & $\begin{array}{l}\text { Вид на } \\
\text { конструкција }\end{array}$ & $\begin{array}{l}\text { Дебелина } \\
\mathrm{d}=(\mathrm{m})\end{array}$ & $\begin{array}{l}\text { Коефициент на } \\
\text { проводливост } \\
\Lambda=[(\mathrm{W} / \mathrm{mK})]\end{array}$ & $\begin{array}{l}\text { Термички } \\
\text { отпор } \\
\mathrm{R}=\mathrm{d} / \Lambda\left(\mathrm{m}^{2} \mathrm{~K} / \mathrm{W}\right)\end{array}$ \\
\hline 1 & $\begin{array}{l}\text { Благороден } \\
\text { фасаден малтер }\end{array}$ & 0,03 & 0,70 & 0,042 \\
\hline 2 & $\begin{array}{l}\text { Керамички } \\
\text { шуплив блок }\end{array}$ & 0,25 & 0,61 & 0,409 \\
\hline 3 & $\begin{array}{l}\text { Варов малтер } \\
\text { продолжен }\end{array}$ & 0,02 & 0,85 & 0,023 \\
\hline
\end{tabular}

Од табела3.4.1.1(МKC EN ISO 6946/ A1)

Rsi $=0.13$

Rse $=0.04$

Од тука $\mathrm{Rt}=\mathrm{Rsi}+\sum \mathrm{R}+\mathrm{Rse}$

$\mathrm{Rt}=0.13+0.474+0.04=0.63$

$\mathrm{U}=1 / \mathrm{Rt}=1 / 0.644=1.55 \mathrm{~W} / \mathrm{m}^{2} \mathrm{~K}$

HS2

\begin{tabular}{|l|l|l|l|l|}
\hline p.бр & $\begin{array}{l}\text { Вид на } \\
\text { конструкција }\end{array}$ & $\begin{array}{l}\text { Дебелина } \\
\mathrm{d}=(\mathrm{m})\end{array}$ & $\begin{array}{l}\text { Коефициент на } \\
\text { проводливост } \\
\Lambda=[(\mathrm{W} / \mathrm{mK})]\end{array}$ & $\begin{array}{l}\text { Термички } \\
\text { отпор } \\
\mathrm{R}=\mathrm{d} / \Lambda\left(\mathrm{m}^{2} \mathrm{~K} / \mathrm{W}\right)\end{array}$ \\
\hline 1 & $\begin{array}{l}\text { Армирано } \\
\text { бетонско платно }\end{array}$ & 0,20 & 2.04 & 0,098 \\
\hline 2 & Варов малтер & 0,02 & 0,85 & 0,023 \\
\hline
\end{tabular}

Од табела3.4.1.1(MKC EN ISO 6946/ A1)

Rsi $=0.13$

Rse $=0.04$

Од тука Rt=Rsi+ $\sum \mathrm{R}+\mathrm{Rse}$

$\mathrm{R} t=0.13+0.121+0.04=0.291$

$\mathrm{U}=1 / \mathrm{Rt}=1 / 0.291=\mathbf{3 , 4 3} \mathrm{W} / \mathrm{m}^{2} \mathrm{~K}$ 
Д1 (Под над негреан подрум)

\begin{tabular}{|l|l|l|l|l|}
\hline р.бр & $\begin{array}{l}\text { Вид на } \\
\text { конструкција }\end{array}$ & $\begin{array}{l}\text { Дебелина } \\
\mathrm{d}=(\mathrm{m})\end{array}$ & $\begin{array}{l}\text { Коефициент на } \\
\text { проводливост } \\
\Lambda=[(\mathrm{W} / \mathrm{mK})]\end{array}$ & $\begin{array}{l}\text { Термички } \\
\text { отпор } \\
\mathrm{R}=\mathrm{d} / \Lambda\left(\mathrm{m}^{2} \mathrm{~K} / \mathrm{W}\right)\end{array}$ \\
\hline 1 & Паркет & 0,02 & 0,21 & 0,095 \\
\hline 2 & А.Б.Плоча & 0,15 & 2.04 & 0,073 \\
\hline
\end{tabular}

Од табела3.4.1.1(МКС EN ISO 6946/ A1)

Rsi=0.17

Rse $=0.17$

Од тука $\mathrm{Rt}=\mathrm{Rsi}+\sum \mathrm{R}+\mathrm{Rse}$

$\mathrm{Rt}=0.17+0.168+0.17=0.52$

$\mathrm{U}=1 / \mathrm{Rt}=1 / 0.508=1,96 \mathrm{~W} / \mathrm{m}^{2} \mathrm{~K}$

Д2 (Под над негреан подрум)

\begin{tabular}{|l|l|l|l|l|}
\hline p.бр & $\begin{array}{l}\text { Вид на } \\
\text { конструкција }\end{array}$ & $\begin{array}{l}\text { Дебелина } \\
\mathrm{d}=(\mathrm{m})\end{array}$ & $\begin{array}{l}\text { Коефициент на } \\
\text { проводливост } \\
\Lambda=[(\mathrm{W} / \mathrm{mK})]\end{array}$ & $\begin{array}{l}\text { Термички } \\
\text { отпор } \\
\mathrm{R}=\mathrm{d} / \Lambda\left(\mathrm{m}^{2} \mathrm{~K} / \mathrm{W}\right)\end{array}$ \\
\hline 1 & К.плочки & 0,01 & 1,28 & 0,008 \\
\hline 2 & А.Б.Плоча & 0,15 & 2,04 & 0,073 \\
\hline
\end{tabular}

Од табела3.4.1.1(МKC EN ISO 6946/ A1)

Rsi=0.17

Rse $=0.17$

Од тука $\mathrm{Rt}=\mathrm{Rsi}+\sum \mathrm{R}+\mathrm{Rse}$

$\mathrm{Rt}=0.17+0.081+0.17=0.421$

$\mathrm{U}=1 / \mathrm{Rt}=1 / 0.421=2.37 \mathrm{~W} / \mathrm{m}^{2} \mathrm{~K}$

HS(тм) - топлотен мост кај балконска конзола - површински*

\begin{tabular}{|l|l|l|l|l|}
\hline р.бр & $\begin{array}{l}\text { Вид на } \\
\text { конструкција }\end{array}$ & $\begin{array}{l}\text { Дебелина } \\
\mathrm{d}=(\mathrm{m})\end{array}$ & $\begin{array}{l}\text { Коесициент на } \\
\text { проводливост } \\
\Lambda=[(\mathrm{W} / \mathrm{mK})]\end{array}$ & $\begin{array}{l}\text { Термички } \\
\text { отпор } \\
\mathrm{R}=\mathrm{d} / \lambda\left(\mathrm{m}^{2} \mathrm{~K} / \mathrm{W}\right)\end{array}$ \\
\hline 1 & Терацо обработка & & 2,04 & 0,392 \\
\hline 2 & А.Б.Платно & $0,80^{*}$ & $\Sigma \mathrm{R}=0.392$ \\
\hline
\end{tabular}


Од табела3.4.1.1(МКС EN ISO 6946/ A1)

Rsi=0.13

Rse $=0.04$

Од тука $\mathrm{Rt}=\mathrm{Rsi}+\sum \mathrm{R}+\mathrm{Rse}$

$\mathrm{Rt}=0.13+0,392+0.04=0,562$

$\mathrm{U}=1 / \mathrm{Rt}=1 / 0,562=1,779 \mathrm{~W} / \mathrm{m}^{2} \mathrm{~K}>\mathrm{Umax}=0,35 \mathrm{~W} / \mathrm{m}^{2} \mathrm{~K}$ (незадоволува)

Топлотните мостови опфаќаат 10-15\% од вкупната површина на надворешните sидови. Врз основа на тоа може да се пресмета просечен коефициент на премин на топлина за надворешни зидови:

$U_{\text {пр }}=U_{\text {нs }} \times 0,85+U_{\text {ep }} \times 0,15=0,27 \times 0,85+1,77 \times 0,15=0,229+0,265=0,494 \mathrm{~W} / \mathrm{m}^{2} \mathrm{~K}$ $\mathrm{U}_{\text {пр }}=0,494 \mathrm{~W} / \mathrm{m}^{2} \mathrm{~K}>\mathrm{Umax}=0,35 \mathrm{~W} / \mathrm{m}^{2} \mathrm{~K}$ (незадоволува)

* - дебелината на армираното бетонско платно од 80 см. е земена како “просечна“ дебелина, бидејќи се работи за балкони со должина од цца. 1,4м“, но целата површина на балконот не влиае на вкупниот пренос на топлина.

Д4 (под-под во соба меѓукат)

\begin{tabular}{|l|l|l|l|l|}
\hline р.бр & $\begin{array}{l}\text { Вид на } \\
\text { конструкција }\end{array}$ & $\begin{array}{l}\text { Дебелина } \\
\mathrm{d}=(\mathrm{m})\end{array}$ & $\begin{array}{l}\text { Коефициент на } \\
\text { проводливост } \\
\Lambda=[(\mathrm{W} / \mathrm{mK})]\end{array}$ & $\begin{array}{l}\text { Термички } \\
\text { отпор } \\
\mathrm{R}=\mathrm{d} / \lambda\left(\mathrm{m}^{2} \mathrm{~K} / \mathrm{W}\right)\end{array}$ \\
\hline 1 & Паркет & 0,02 & 0,21 & 0,095 \\
\hline 2 & А.Б.Плоча & 0,15 & 2,04 & 0,073 \\
\hline
\end{tabular}

Од табела3.4.1.1(МKC EN ISO 6946/ A1)

Rsi=0.10

Rse $=0.08$

Од тука $\mathrm{Rt}=\mathrm{Rsi}+\sum \mathrm{R}+\mathrm{Rse}$

$\mathrm{Rt}=0.10+0.168+0.08=0.348$

$\mathrm{U}=1 / \mathrm{Rt}=1 / 0.348=2.87 \mathrm{~W} / \mathrm{m}^{2} \mathrm{~K}$ 
BS1

\begin{tabular}{|l|l|l|l|l|}
\hline р.бр & $\begin{array}{l}\text { Вид на } \\
\text { конструкција }\end{array}$ & $\begin{array}{l}\text { Дебелина } \\
\mathrm{d}=(\mathrm{m})\end{array}$ & $\begin{array}{l}\text { Коефициент на } \\
\text { проводливост } \\
\Lambda=[(\mathrm{W} / \mathrm{mK})]\end{array}$ & $\begin{array}{l}\text { Термички } \\
\text { отпор } \\
\mathrm{R}=\mathrm{d} / \Lambda\left(\mathrm{m}^{2} \mathrm{~K} / \mathrm{W}\right)\end{array}$ \\
\hline 1 & Варов малтер & 0,02 & 0,85 & 0,024 \\
\hline 2 & $\begin{array}{l}\text { Керамички } \\
\text { шуплив блок }\end{array}$ & 0,25 & 0,61 & 0,401 \\
\hline 3 & $\begin{array}{l}\text { Варов малтер } \\
0,02\end{array}$ & 0,85 & 0,024 \\
\hline
\end{tabular}

$$
\sum R=0.449
$$

Од табела3.4.1.1(МKC EN ISO 6946/ A1)

Rsi=0.13

Rse $=0.13$

Од тука $\mathrm{Rt}=\mathrm{Rsi}+\sum \mathrm{R}+\mathrm{Rse}$

$\mathrm{Rt}=0.13+0.449+0.13=0.709$

$\mathrm{U}=1 / \mathrm{Rt}=1 / 0.709=1.41 \mathrm{~W} / \mathrm{m}^{2} \mathrm{~K}$

T1

\begin{tabular}{|l|l|l|l|l|}
\hline р.бр & $\begin{array}{l}\text { Вид на } \\
\text { конструкција }\end{array}$ & $\begin{array}{l}\text { Дебелина } \\
\mathrm{d}=(\mathrm{m})\end{array}$ & $\begin{array}{l}\text { Коефициент на } \\
\text { проводливост } \\
\Lambda=[(\mathrm{W} / \mathrm{mK})]\end{array}$ & $\begin{array}{l}\text { Термички } \\
\text { отпор } \\
\mathrm{R}=\mathrm{d} / \Lambda\left(\mathrm{m}^{2} \mathrm{~K} / \mathrm{W}\right)\end{array}$ \\
\hline 1 & Бетонски плочи & 0,02 & 2,33 & 0,009 \\
\hline 2 & Тер хартија & 0,003 & 0,15 & 0,020 \\
\hline 3 & Песок & 0,05 & 0,58 & 0,086 \\
\hline 4 & $\begin{array}{l}\text { Битуменски } \\
\text { премаз }\end{array}$ & 0,01 & 0,17 & 0,059 \\
\hline 5 & А.Б.Плоча & 0,15 & 2,04 & 0,073 \\
\hline
\end{tabular}

$\sum R=0.247$

Од табела3.4.1.1(МKC EN ISO 6946/ A1)

Rsi=0.10

Rse $=0.04$ 
Од тука $\mathrm{Rt}=\mathrm{Rsi}+\sum \mathrm{R}+\mathrm{Rse}$

$\mathrm{Rt}=0.10+0.247+0.04=0.387$

$\mathrm{U}=1 / \mathrm{Rt}=1 / 0.387=2.58 \mathrm{~W} / \mathrm{m}^{2} \mathrm{~K}$

K1

\begin{tabular}{|l|l|l|l|l|}
\hline Р.бр. & $\begin{array}{l}\text { Вид на } \\
\text { конструкција }\end{array}$ & $\begin{array}{l}\text { Дебелина } \\
\mathrm{d}=(\mathrm{m})\end{array}$ & $\begin{array}{l}\text { Коефициент } \\
\text { на } \\
\text { проводливост } \\
\Lambda=[(\mathrm{W} / \mathrm{mK})]\end{array}$ & $\begin{array}{l}\text { Термички } \\
\text { отпор } \\
\mathrm{R}=\mathrm{d} / \mathrm{\lambda}(\mathrm{m} 2 \mathrm{~K} / \mathrm{W})\end{array}$ \\
\hline 1 & $\begin{array}{l}\text { Битуменски } \\
\text { премаз }\end{array}$ & 0,01 & 0,17 & 0,059 \\
\hline 2 & А.Б.Плоча & 0,15 & 2,04 & 0,073 \\
\hline
\end{tabular}

$\sum R=0.132$

Rsi $=0.10$

Rse $=0.04$

Од тука $\mathrm{Rt}=\mathrm{Rsi}+\sum \mathrm{R}+\mathrm{Rse}$

$\mathrm{Rt}=0.10+0.132+0.04=0.272$

$\mathrm{U}=1 / \mathrm{Rt}=1 / 0.272=3,676 \mathrm{~W} / \mathrm{m}^{2} \mathrm{~K}$

8. ПАРЦИЈАЛНА ПРЕСМЕТКА НА ПОВРШИНИТЕ НА ГРАДЕЖНИТЕ КОНСТРУКЦИИ ( СПОРЕД МКС ЕN ISO13789 )

8.1 Надворешни sидови без прозори и врати со еркер во греан простор Анад.

8.2 Надворешни врати и прозори во греан простор

$A=907 \mathrm{M}^{2}$

8.3 Горна завршна плоча, под покрив

$A=355,47 \mathrm{M}^{2}-$ поткровје

A=178,6 $\mathrm{M}^{2}$ - проодна тераса

8.4 Приземје, подна површина вкупна внатрешна врз подрум $A=285 M^{2}+($ влез негреан $)=285+44,17=329,17 M^{2}$

8.5Sидови внатрешно јадро (према негреан простор) $=153.12+622.03=775.15 \mathrm{M}^{2}$

СЕ ВКУПНО A=4 645,39 $\mathrm{M}^{2}$ 
9. ПРЕСМЕТКА НА ВКУПНИ ТРАНСМИСИСКИ ЗАГУБИ НИЗ ОБВИВКАТА НА OБJEKTOT

\begin{tabular}{|c|c|c|c|c|c|}
\hline $\begin{array}{l}\text { p.б } \\
\text { p. }\end{array}$ & Опис на град. елементи & ознака & $\left(\mathrm{U} / \mathrm{m}^{2} \mathrm{~K}\right)$ & $\begin{array}{c}\mathrm{A} \\
\mathrm{m}^{2}\end{array}$ & $\begin{array}{l}\mathrm{U} \times \mathrm{A} \\
(\mathrm{W} / \mathrm{K})\end{array}$ \\
\hline 1 & Надворешен sид (керамички блок) & HS1 & 1,55 & 1136,2 & 1761,11 \\
\hline 1 & Надворешен зид (а.б. платно) & HS2 & 3,43 & 963,8 & 3305,83 \\
\hline 2 & Надворешни прозори / врати & $\mathrm{H} \Pi / \mathrm{HB}$ & 3,5 & 907 & 3174,5 \\
\hline 3 & Горна завршна плоча, проодна тераса & $\mathrm{T}$ & 2.58 & 178,6 & 460,788 \\
\hline 4 & Кров на поткровје & K1 & 3,67 & 355,5 & 1306,70 \\
\hline 5 & Приземје, подна површина врз подрум & Д & 1.96 & 329,17 & 645.17 \\
\hline 6 & Внатрешен sид кај скалишно јадро & BS1 & 1,41 & 775.15 & 1092.96 \\
\hline 7 & $\begin{array}{l}\text { Топлински мост кај балконска конзола } \\
(15 \% \text { од површината на надворешните } \\
\text { sидови) }\end{array}$ & $\mathrm{HS}(\mathrm{TM})$ & 0,49 & 315 & 155,93 \\
\hline & & & & $\Sigma \mathrm{H}_{\mathrm{tr}}$ & 11902,98 \\
\hline
\end{tabular}

10. ПРЕСМЕТКА НА КОЕФИЦИЕНТ СО СПЕЦИФИЧНИ ТОПЛИНСКИ ЗАГУБИ CO ТРАНСМИСИJА H'т - W/m²K

$\mathrm{Htr}=11$ 902,98 W/K ( вкупни трансмисиони топлотни загуби)

$\mathrm{A}=4645,39 \mathrm{~m} 2$ (површина на обвивка на зградата)

H'т = Htr , $\mathrm{A}=11902,98 / 4645,39=2,56 \mathrm{~W} / \mathrm{m} 2 \mathrm{~K}$

Од тука според формулата од Табела 2 од Правилникот следува

Н'т = 0,39+0,19 / fo ( за згради при поголема реконструкција )

Н'т $=0,39+0,19 / 0,30=0.39+0.63=1,02 \mathrm{~W} / \mathrm{m} 2 \mathrm{~K}$

Вредноста $(2,56)$ е поголема од вредностите во Табелата $(1,02)$ и не е во согласност со Правилникот. 
11.ПРЕСМЕТКА НА ЕНЕРГЕТСКИТЕ ПОТРЕБИ (ЗА ГРЕЕЊЕ) НА ГОДИШНО НИВО Q СО ВКЛУЧЕНО ВЛИЈАНИЕ НА ТОПЛИНСКИТЕ МОСТОВИ

$\mathbf{Q}=\left(\mathbf{H}^{\prime} \mathbf{T} \times \Delta \mathbf{U} \mathbf{t v} \times \mathbf{A} \times \mathbf{D D} \times \mathbf{\hbar}\right) / \mathbf{A n}=$

$(2,56 \times 1.35 \times 4645,39 \times 2600 \times 10) / 3192=$

417416163,84 / $3192=130769,474 \mathrm{Wh} / \mathrm{m}^{2} \mathrm{a}=130.76 \mathbf{k h} / \mathbf{m}^{2} \mathbf{a}$

каде:

$\mathrm{H}^{\prime} \mathbf{\tau}=2,56 \mathrm{~W} / \mathrm{m}^{2} \mathrm{~K}$ - "коефициент на специфични топлински загуби со трансмисија" или топлински загуби причинети од минување на топлината низ обвивката на зградата.
$\Delta \mathrm{Utv}=1,35$
- корекционен фактор на влијание на топлински мостови.
$A=4645,39 M^{2}$
- обвивка на зграда.
$D D=2600$
- степен грејни денови од Правилникот.
$\mathrm{h}=10$
-- број на часови за греење во текот на еден ден.
An $=3192 M^{2}$
-- корисна грејна површина.

Со оваа пресметка од предлог Правилникот не се земени ВЕНТИЛАЦИОНИ топлотни загуби.

Степен ден* претставува разлика меѓу внатрешна проектна температура и средна надворешна проектна температура во грејна сезона, помножена со број на денови за греење. За климатските услови на Општина Карпош изнесува $\mathrm{DD}=2600$.

Корисна површина на зградата* е внатрешна нето подна површина на греан простор.

Обвивка на зградата* е вкупна надворешна површина на зградата ( sидови, покриви, м.к.к. под и над греан простор, еркери, отвори, хоризонтални и вертикални конструкции вкопани во терен низ кој топлината се пренесува кон надворешноста, пресметана во согласност со стандардот МКС EN ISO 13789.

Нето греан волумен на зграда* е волуменот на зградата затворен со надворешната обвивка на зградата, пресметан со внатрешни димензии, во согласност со стандардот МКC EN ISO 13789.

Бруто греан волумен на зграда* е волуменот на зграда затворен со надворешната обвивка, пресметан со надворешни димензии, во согласност со стандардот MKC EN ISO 13789. За поедноставна пресметка може да се примени $\mathrm{V}=0.8 \mathrm{Ve}(\mathrm{m} 3)$. 


\section{ПРИЛОГ бр.3}

\section{Елаборат за Енергетска Ефикасност според предлог \\ Правилник на Општина Карпош \\ (со нови предложени мерки за обнова)}

\section{1. ПРОЕКТНИ ПАРАМЕТРИ}

Надворешни проектни параметри:

-во зима : Температура

$$
\begin{aligned}
& \theta_{\mathrm{e}}=-15{ }^{\circ} \mathrm{C} \\
& \theta_{\mathrm{e}}=+35{ }^{\circ} \mathrm{C}
\end{aligned}
$$

-во лето: Температура

Внатрешни проектни услови:

-во зима : Температура

$\theta_{\mathrm{e}}=+20^{\circ} \mathrm{C}$

-во лето: Температура

$\theta_{\mathrm{e}}=+26{ }^{\circ} \mathrm{C}$

-степен ден *

$\mathrm{DD}=2600$

Бидејки е предвидена доградба на поткровјето со нови простории кои се прилепени на постоечките, настаната е промена во следните параметри. (Зголемена е површината на обвивка на фасадата, како и корисната површина кај поткровјето.)

2.КОРИСНА ПОВРШИНА НА ЗГРАДАТА * $A n=3192 \mathrm{~m}^{2}$ преминува во $\mathbf{3 3 4 1 , 0 2} \mathbf{m}^{2}$ 3.ОБВИВКА НА ЗГРАДАТА 4.НЕТО ГРЕАН ВОЛУМЕН НА ЗГРАДАТА ${ }^{*} V=8487 \mathrm{~m}^{3}$ преминува во $\mathbf{8 8 6 0 , 3} \mathbf{m}^{3}$ 5.БРУТО ГРЕАН ВОЛУМЕН НА ЗГРАДА ${ }^{*}$ Vе $=10609 \mathrm{~m}^{3}$ преминува во $11075,37 \mathrm{~m}^{3}$ 6.ФАКТОР ФОРМА НА ЗГРАДАТА $\quad$ fo $=$ A $/ \mathrm{Ve}=4725,92 / 11075,37=0.42$ 7.ПРЕСМЕТКА НА КОЕФИЦИЕНТИ НА ПРЕНЕСУВАҢЕ НА ТОПЛИНА U ЗА СИТЕ ГРАДЕЖНИ КОНСТРУКЦИИ 
Вкупно,табела U/Umax:

$\mathbf{U}$ вредностите кои не задоволуваат вредност на $\mathbf{U}_{\max }$, по предложената обнова се сепак поблиску до исполнување на истата.

\begin{tabular}{|c|c|c|c|c|c|}
\hline p.бp & ПОЛОЖБА & ознака & $\begin{array}{c}\mathbf{U} \\
{\left[\left(\mathrm{W} / \mathrm{m}^{2} \mathrm{~K}\right)\right]}\end{array}$ & $\begin{array}{c}\mathbf{U}_{\max } \\
{\left[\left(\mathrm{W} / \mathrm{m}^{2} \mathrm{~K}\right)\right]}\end{array}$ & $\begin{array}{c}\text { Исполенето } \\
\text { ДА / НЕ }\end{array}$ \\
\hline 1 & Надворешен sид - фасада & HS1 & 0.27 & 0,35 & ДА \\
\hline 2 & $\begin{array}{l}\text { Надворешен sид - фрасаден } \\
\text { - АБ платно }\end{array}$ & HS2 & 0,28 & 0,35 & ДА \\
\hline 3 & $\begin{array}{l}\text { Под (паркет - над негреан } \\
\text { подрум) }\end{array}$ & Д1 & 0,56 & 0,35 & $\mathrm{HE}$ \\
\hline 4 & $\begin{array}{l}\text { Под (плочки - над негреан } \\
\text { подрум) }\end{array}$ & Д2 & 0,59 & 0,35 & $\mathrm{HE}$ \\
\hline 5 & $\begin{array}{l}\text { Топлотен мост кај балконска } \\
\text { конзола }\end{array}$ & $\mathrm{HS}(\mathrm{TM})$ & 0,302 & 0,35 & ДА \\
\hline 6 & Под - под во соба на кат & Д4 & 2,87 & 1,35 & $\mathrm{HE}$ \\
\hline 7 & $\begin{array}{l}\text { Внатрешен преграден sид - } \\
\text { стан - скалишен простор }\end{array}$ & BS1 & 1,41 & 0,35 & $\mathrm{HE}$ \\
\hline 8 & Кров1 & K1 & 0,24 & 0,20 & ДА /HЕ \\
\hline 9 & Кров2 & K2 & 0,22 & 0,20 & ДА \\
\hline
\end{tabular}


7.1 Парцијална пресметка на коефициенти на пренесување на топлина U $3 a$ сите постоечки градежни конструкции.

\section{HS1}

\begin{tabular}{|c|l|c|c|c|}
\hline р.бр & $\begin{array}{l}\text { Вид на } \\
\text { конструкција }\end{array}$ & $\begin{array}{c}\text { Дебелина } \\
\mathrm{d}=(\mathrm{m})\end{array}$ & $\begin{array}{c}\text { Коефициент на } \\
\text { проводливост } \\
\wedge=[(\mathrm{W} / \mathrm{mK})]\end{array}$ & $\begin{array}{l}\text { Термички } \\
\text { отпор } \\
\mathrm{R}=\mathrm{d} / \Lambda\left(\mathrm{m}^{2} \mathrm{~K} / \mathrm{W}\right)\end{array}$ \\
\hline 1 & $\begin{array}{l}\text { Експандиран } \\
\text { полистирен }\end{array}$ & 0,12 & 0,04 & 3 \\
\hline 2 & $\begin{array}{l}\text { Благороден } \\
\text { фасаден малтер }\end{array}$ & 0,03 & 0,70 & 0,042 \\
\hline 3 & $\begin{array}{l}\text { Керамички } \\
\text { шуплив блок }\end{array}$ & 0,25 & 0,61 & 0,409 \\
\hline 4 & $\begin{array}{l}\text { Варов малтер } \\
\text { подолжен }\end{array}$ & 0,02 & 0,85 & 0,023 \\
\hline
\end{tabular}

$\sum R=3.474$

Од табела3.4.1.1(МKC EN ISO 6946/ A1)

Rsi=0.13

Rse $=0.04$

Од тука $\mathrm{Rt}=\mathrm{Rsi}+\sum \mathrm{R}+\mathrm{Rse}$

$\mathrm{Rt}=0.13+3.474+0.04=3,644$

$\mathrm{U}=1 / \mathrm{Rt}=1 / 3.644=0,27 \mathrm{~W} / \mathrm{m}^{2} \mathrm{~K}<\mathrm{Umax}=\mathbf{0 , 3 5} \mathrm{W} / \mathrm{m}^{2} \mathrm{~K}$ (задоволува)

\section{HS2}

\begin{tabular}{|c|l|c|c|c|}
\hline $\begin{array}{l}\text { p. } \\
\text { бр }\end{array}$ & $\begin{array}{l}\text { Вид на } \\
\text { конструкција }\end{array}$ & $\begin{array}{l}\text { Дебелина } \\
\mathrm{d}=(\mathrm{m})\end{array}$ & $\begin{array}{l}\text { Коефициент на } \\
\text { проводливост } \\
\Lambda=[(\mathrm{W} / \mathrm{mK})]\end{array}$ & $\begin{array}{l}\text { Термички } \\
\text { отпор } \\
\mathrm{R}=\mathrm{d} / \lambda\left(\mathrm{m}^{2} \mathrm{~K} / \mathrm{W}\right)\end{array}$ \\
\hline 1 & $\begin{array}{l}\text { Експандиран } \\
\text { полистирен со } \\
\text { д=5+8 см }\end{array}$ & 0,13 & 0,04 & 3,25 \\
\hline 2 & $\begin{array}{l}\text { Армирано } \\
\text { бетонско платно }\end{array}$ & 0,20 & 2.04 & 0,098 \\
\hline 3 & Варов малтер & 0,02 & 0,85 & 0,023 \\
\hline
\end{tabular}

$\sum R=3,371$ 
Од табела3.4.1.1(МКС EN ISO 6946/ A1)

Rsi=0.13

Rse $=0.04$

Од тука $\mathrm{Rt}=\mathrm{Rsi}+\sum \mathrm{R}+\mathrm{Rse}$

$\mathrm{Rt}=0.13+3,371+0.04=3,541$

$\mathrm{U}=1 / \mathrm{Rt}=1 / 3,541=\mathbf{0 , 2 8} \mathrm{W} / \mathrm{m}^{2} \mathrm{~K}<\mathrm{Umax}=\mathbf{0 , 3 5} \mathrm{W} / \mathrm{m}^{2} \mathrm{~K}$ (задоволува)

Д1- (под над подрум)

\begin{tabular}{|c|l|c|c|c|}
\hline р.бр & $\begin{array}{l}\text { Вид на } \\
\text { конструкција }\end{array}$ & $\begin{array}{l}\text { Дебелина } \\
\mathrm{d}=(\mathrm{m})\end{array}$ & $\begin{array}{l}\text { Коесициент на } \\
\text { проводливост } \\
\Lambda=[(\mathrm{W} / \mathrm{mK})]\end{array}$ & $\begin{array}{l}\text { Термички } \\
\text { отпор } \\
\mathrm{R}=\mathrm{d} / \Lambda\left(\mathrm{m}^{2} \mathrm{~K} / \mathrm{W}\right)\end{array}$ \\
\hline 1 & Паркет & 0,02 & 0,21 & 0,095 \\
\hline 2 & А.Б.Плоча & 0,15 & 2.04 & 0,073 \\
\hline 3 & $\begin{array}{l}\text { Камена волна д= } \\
\text { Бсм }\end{array}$ & 0,05 & 0,04 & 1,25 \\
\hline
\end{tabular}

$\sum R=1,418$

Од табела3.4.1.1(МKC EN ISO 6946/ A1)

Rsi $=0.17$

Rse $=0.17$

Од тука $\mathrm{Rt}=\mathrm{Rsi}+\sum \mathrm{R}+\mathrm{Rse}$

$\mathrm{Rt}=0.17+1,418+0.17=1,758$

$\mathrm{U}=1 / \mathrm{Rt}=1 / 1,758=0,56 \mathrm{~W} / \mathrm{m}^{2} \mathrm{~K}>\mathrm{Umax}=\mathbf{0 , 3 5} \mathrm{W} / \mathrm{m}^{2} \mathrm{~K}$ (не задоволува)

Д2 (под над подрум)

\begin{tabular}{|c|l|c|c|c|}
\hline р.бр & $\begin{array}{l}\text { Вид на } \\
\text { конструкција }\end{array}$ & $\begin{array}{l}\text { Дебелина } \\
\mathrm{d}=(\mathrm{m})\end{array}$ & $\begin{array}{l}\text { Коефициент на } \\
\text { проводливост } \\
\Lambda=[(\mathrm{W} / \mathrm{mK})]\end{array}$ & $\begin{array}{l}\text { Термички } \\
\text { отпор } \\
\mathrm{R}=\mathrm{d} / \lambda\left(\mathrm{m}^{2} \mathrm{~K} / \mathrm{W}\right)\end{array}$ \\
\hline 1 & К.плочки & 0,01 & 1,28 & 0,008 \\
\hline 2 & А.Б.Плоча & 0,15 & 2,04 & 0,073 \\
\hline 3 & $\begin{array}{l}\text { Камена волна д= } \\
\text { 5см }\end{array}$ & 0,05 & 0,04 & 1,25 \\
\hline
\end{tabular}

$\sum R=1,331$

Од табела3.4.1.1(МКС EN ISO 6946/ A1)

Rsi $=0.17$

Rse $=0.17$ 
Од тука $\mathrm{Rt}=\mathrm{Rsi}+\sum \mathrm{R}+\mathrm{Rse}$

$\mathrm{Rt}=0.17+1,331+0.17=1,671$

$\mathrm{U}=1 / \mathrm{Rt}=1 / 1,671=\mathbf{0 , 5 9} \mathrm{W} / \mathrm{m}^{2} \mathrm{~K}>\mathrm{Umax}=\mathbf{0 , 3 5} \mathbf{W} / \mathrm{m}^{2} \mathrm{~K}$ ( не задоволува )

HS(тм)-ТОПЛОТЕН МОСТ (балконска конзола)

\begin{tabular}{|c|l|c|c|c|}
\hline $\begin{array}{l}\text { p. } \\
\text { бр }\end{array}$ & $\begin{array}{l}\text { Вид } \\
\text { конструкција }\end{array}$ & $\begin{array}{l}\text { Дебелина } \\
\mathrm{d}=(\mathrm{m})\end{array}$ & $\begin{array}{l}\text { Коесициент на } \\
\text { проводливост } \\
\Lambda=[(\mathrm{W} / \mathrm{mK})]\end{array}$ & $\begin{array}{l}\text { Термичкиотпор } \\
\mathrm{R}=\mathrm{d} / \Lambda\left(\mathrm{m}^{2} \mathrm{~K} / \mathrm{W}\right)\end{array}$ \\
\hline 1 & $\begin{array}{l}\text { Експандиран } \\
\text { полистирен со } \\
\text { д= 6 см }\end{array}$ & 0,06 & 0,04 & 1,5 \\
\hline 2 & $\begin{array}{l}\text { Армирано } \\
\text { бетонско платно }\end{array}$ & $\mathbf{0 , 8 0 *}$ & 2.04 & 0,392 \\
\hline
\end{tabular}

$\sum R=1,892$

Од табела3.4.1.1(МKC EN ISO 6946/ A1)

Rsi=0.13

Rse $=0.04$

Од тука $\mathrm{Rt}=\mathrm{Rsi}+\sum \mathrm{R}+\mathrm{Rse}$

$\mathrm{Rt}=0.13+1,892+0.04=2,062$

$\mathrm{U}=1 / \mathrm{Rt}=1 / 2,062=0,485 \mathrm{~W} / \mathrm{m}^{2} \mathrm{~K}>\mathrm{Umax}=\mathbf{0 , 3 5} \mathrm{W} / \mathrm{m}^{2} \mathrm{~K}$ (незадоволува)

Топлотните мостови опфаќаат 10-15\% од вкупната површина на надворешните sидови. Врз основа на тоа може да се пресмета просечен коефициент на премин на топлина за надворешни зидови:

$U_{\text {пр }}=U_{\text {нs }} \times 0,85+U_{\text {ep }} \times 0,15=0,27 \times 0,85+0,48 \times 0,15=0,230+0,072=0,302 \mathrm{~W} / \mathrm{m}^{2} \mathrm{~K}$ $\mathrm{U}_{\text {пр }}=0,302 \mathrm{~W} / \mathrm{m}^{2} \mathrm{~K}<\mathrm{Umax}=0,35 \mathrm{~W} / \mathrm{m}^{2} \mathrm{~K}$ (задоволува)

* - дебелината на армираното бетонско платно од 80 см. е земена како “просечна“ дебелина, бидејќи се работи за балкони со должина од цца. 1,4 м', но целата површина на балконот не влиае на вкупниот пренос на топлина 
Д4 - м.к.к. меѓу спратови

\begin{tabular}{|l|l|l|l|l|}
\hline р.бр & $\begin{array}{l}\text { Вид на } \\
\text { конструкција }\end{array}$ & $\begin{array}{l}\text { Дебелина } \\
\mathrm{d}=(\mathrm{m})\end{array}$ & $\begin{array}{l}\text { Коефициент на } \\
\text { проводливост } \\
\Lambda=[(\mathrm{W} / \mathrm{mK})]\end{array}$ & $\begin{array}{l}\text { Термички } \\
\text { отпор } \\
\mathrm{R}=\mathrm{d} / \lambda\left(\mathrm{m}^{2} \mathrm{~K} / \mathrm{W}\right)\end{array}$ \\
\hline 1 & Паркет & 0,02 & 0,21 & 0,095 \\
\hline 2 & А.Б.Плоча & 0,15 & 2,04 & 0,073 \\
\hline
\end{tabular}

$$
\sum R=0.168
$$

Од табела3.4.1.1(МКС EN ISO 6946/ A1)

Rsi $=0.10$

Rse $=0.08$

Од тука $\mathrm{Rt}=\mathrm{Rsi}+\sum \mathrm{R}+\mathrm{Rse}$

$\mathrm{Rt}=0.10+0.168+0.08=0.348$

$\mathrm{U}=1 / \mathrm{Rt}=1 / 0.348=2.87 \mathrm{~W} / \mathrm{m}^{2} \mathrm{~K}>\mathrm{Umax}=1,35 \mathrm{~W} / \mathrm{m}^{2} \mathrm{~K}$ (не задоволува)

BS1

\begin{tabular}{|l|l|l|l|l|}
\hline р.бр & $\begin{array}{l}\text { Вид на } \\
\text { конструкција }\end{array}$ & $\begin{array}{l}\text { Дебелина } \\
\mathrm{d}=(\mathrm{m})\end{array}$ & $\begin{array}{l}\text { Коефициент на } \\
\text { проводливост } \\
\Lambda=[(\mathrm{W} / \mathrm{mK})]\end{array}$ & $\begin{array}{l}\text { Термички } \\
\text { отпор } \\
\mathrm{R}=\mathrm{d} / \lambda\left(\mathrm{m}^{2} \mathrm{~K} / \mathrm{W}\right)\end{array}$ \\
\hline 1 & Варов малтер & 0,02 & 0,85 & 0,024 \\
\hline 2 & $\begin{array}{l}\text { Керамички } \\
\text { шуплив блок }\end{array}$ & 0,25 & 0,61 & 0,401 \\
\hline 3 & Варов малтер & 0,02 & 0,85 & 0,024 \\
\hline
\end{tabular}

Од табела3.4.1.1(МKC EN ISO 6946/ A1)

$\mathrm{Rsi}=0.13$

Rse $=0.13$

Од тука $\mathrm{Rt}=\mathrm{Rsi}+\sum \mathrm{R}+\mathrm{Rse}$

$\mathrm{Rt}=0.13+0.449+0.13=0.709$

$\mathrm{U}=1 / \mathrm{Rt}=1 / 0.709=1.41 \mathrm{~W} / \mathrm{m}^{2} \mathrm{~K}$ 


\section{K1}

\begin{tabular}{|c|c|c|c|c|}
\hline p.бp & $\begin{array}{l}\text { Вид на } \\
\text { конструкција }\end{array}$ & $\begin{array}{l}\text { Дебелина } \\
\mathrm{d}=(\mathrm{m})\end{array}$ & $\begin{array}{l}\text { Коефициент на } \\
\text { проводливост } \\
\wedge=[(\mathrm{W} / \mathrm{mK})]\end{array}$ & $\begin{array}{l}\text { Термички } \\
\text { отпор } \\
\mathrm{R}=\mathrm{d} / \lambda\left(\mathrm{m}^{2} \mathrm{~K} / \mathrm{W}\right)\end{array}$ \\
\hline 1 & $\begin{array}{l}\text { Пластифициран } \\
\text { ребраст челичен } \\
\text { лим врз летви во } \\
\text { два правца }\end{array}$ & & & \\
\hline 2 & Тер хартија & 0,003 & 0,15 & 0,02 \\
\hline 3 & Дашчана оплата & 0.024 & 0,14 & 0,17 \\
\hline 4 & $\begin{array}{l}\text { Минерална } \\
\text { волна меѓу } \\
\text { рогови д=15cм }\end{array}$ & 0,15 & 0,04 & 3,75 \\
\hline 5 & ПЕ фролија & 0,00125 & 0,19 & 0,0066 \\
\hline 6 & А.Б.Плоча & 0,12 & 2,04 & 0,05 \\
\hline
\end{tabular}

Од табела3.4.1.1(MKC EN ISO 6946/ A1)

Rsi $=0.10$

Rse $=0.04$

Од тука Rt=Rsi+ $\sum \mathrm{R}+\mathrm{Rse}$

$\mathrm{Rt}=0.10+4,00+0.04=4,14$

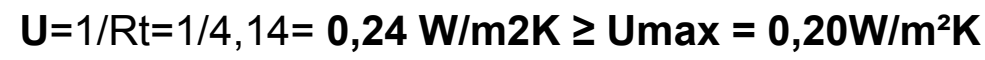

Доколку би се вматнал слој од минарална волна д $=20 \mathrm{~cm}$ наместо $\mathrm{A}=15 \mathrm{~cm}$, Следува $\sum R=5,24$, а Rt ќе изнесува $0.10+5,24+0.04=5.38$ па одтука

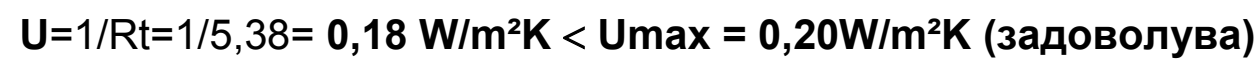


K2

\begin{tabular}{|c|c|c|c|c|}
\hline р.бр & $\begin{array}{l}\text { Вид на } \\
\text { конструкција }\end{array}$ & $\begin{array}{l}\text { Дебелина } \\
\mathrm{d}=(\mathrm{m})\end{array}$ & $\begin{array}{l}\text { Коефициент на } \\
\text { проводливост } \\
\wedge=[(\mathrm{W} / \mathrm{mK})]\end{array}$ & $\begin{array}{l}\text { Термички } \\
\text { отпор } \\
\mathrm{R}=\mathrm{d} / \mathrm{\lambda}\left(\mathrm{m}^{2} \mathrm{~K} / \mathrm{W}\right)\end{array}$ \\
\hline 1 & $\begin{array}{l}\text { Пластифициран } \\
\text { ребраст челичен } \\
\text { лим врз летви во } \\
\text { два правца }\end{array}$ & & & \\
\hline 2 & Тер хартија & 0,003 & 0,15 & 0,020 \\
\hline 3 & Дашчана оплата & 0,024 & 0,14 & 0,17 \\
\hline \multirow[t]{2}{*}{4} & \multirow{2}{*}{$\begin{array}{l}\text { Минерална волна } \\
\text { врз АЛУ фолија } \\
\text { д=15см }\end{array}$} & 0,15 & 0,04 & 3,75 \\
\hline & & 0,001 & $0,026^{*}$ & 0,038 \\
\hline 5 & $\begin{array}{l}\text { Челична } \\
\text { конструкција }\end{array}$ & 0,04 & $0,17^{*}$ & 0,23 \\
\hline 6 & $\begin{array}{l}\text { Гипс картонски } \\
\text { плочи на } \\
\text { подконструкција }\end{array}$ & 0,015 & 0,21 & 0,071 \\
\hline
\end{tabular}

$\sum R=4,279$

* - за алуминиум $\mathrm{R} \lambda=\mathrm{d} / \lambda=26$ × 10-6 =0,000026 m2/KW =0,026 m2/W за $\mathrm{d}=1$ $\mathrm{cm}$.

* - за челик $\mathrm{R} \lambda=\mathrm{d} / \lambda=17$ × 10-5 = 0,00017 m2/KW =0,17 m2/W за $\mathrm{d}=1 \mathrm{~cm}$. податоци земени од табели приложени во Прирачник од Recknagel(2004) Според таблица Рекнагел и Спренгер (Recknagel -Sprenger 1982:732) За челик $\lambda=58=17 \cdot 10^{-} 5$

За алуминиум $\lambda=204=26 \cdot 10^{-} 6$

Од табела3.4.1.1(МKC EN ISO 6946/ A1)

Rsi=0.10

Rse $=0.04$

Од тука $\mathrm{Rt}=\mathrm{Rsi}+\sum \mathrm{R}+\mathrm{Rse}$

$\mathrm{Rt}=0.10+4,279+0.04=4,419$

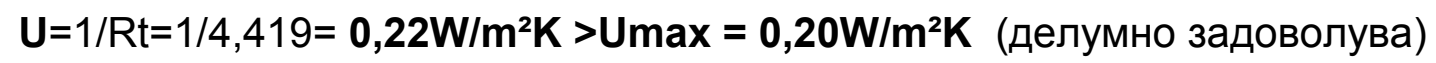


8. ПАРЦИЈАЛНА ПРЕСМЕТКА НА ПОВРШИНИТЕ НА ГРАДЕЖНИТЕ КОНСТРУКЦИИ ( СПОРЕД МКС ЕN ISO13789 )

8.1 Надворешни зидови без прозори и врати со еркер во греан простор Анад.

8.2 Надворешни врати и прозори во греан простор

$A=907 \mathrm{M}^{2}$

8.3 Горна завршна плоча, под покрив

$\mathrm{A}=480 \mathrm{M}^{2}$

8.4 Приземје, подна површина вкупна внатрешна врз подрум $A=285 \mathrm{M} 2+$ (влез негреан $)=285+44,17=329,17 \mathrm{M}^{2}$

8.5Sидови внатрешно јадро (према негреан простор) $=153.12+622.03=775.15 \mathrm{M}^{2}$

CE ВКУПНО A $=4645,92+80=4725,92 \mathrm{~m}^{2}$ (обвивка на зградата)

9. ПРЕСМЕТКА НА ВКУПНИ ТРАНСМИСИСКИ ЗАГУБИ НИЗ ОБВИВКАТА НА OБJEКTOT

\begin{tabular}{|c|c|c|c|c|c|}
\hline $\begin{array}{l}\text { p.б } \\
\text { p. }\end{array}$ & Опис на град. елементи & ознака & $\begin{array}{c}\mathbf{U} \\
\left(\mathrm{W} / \mathrm{m}^{2} \mathrm{~K}\right)\end{array}$ & $\begin{array}{c}\mathrm{A} \\
\mathrm{m}^{2}\end{array}$ & $\begin{array}{l}\mathrm{U} \times \mathrm{A} \\
(\mathrm{W} / \mathrm{K})\end{array}$ \\
\hline 1 & Надворешен sид (керамички блок) & HS1 & 0,27 & $\begin{array}{l}1136,2 \\
+80\end{array}$ & 328,37 \\
\hline 1 & Надворешен sид (а.б. платно) & HS2 & 0,28 & 963,8 & 269,86 \\
\hline 2 & Надворешни прозори / врати & $\mathrm{H} \Pi / \mathrm{HB}$ & 1,7 & 907 & 1541,9 \\
\hline 3 & Покрив & $\mathrm{K} 1 / 2$ & 0,20 & 480 & 96,0 \\
\hline 4 & Приземје, подна површина, врз подрум & Д & 0,56 & 329,17 & 184,33 \\
\hline 5 & Внатрешен sид кај скалишно јадро & BS1 & 1,41 & 775.15 & 1092,96 \\
\hline 6 & $\begin{array}{l}\text { Топлотен мост кај балконска конзола } \\
\text { (15\% од надворешен sид) }\end{array}$ & $\mathrm{HS}(\mathrm{TM})$ & 0,302 & 327 & 98,75 \\
\hline & & & & $\Sigma \mathrm{H}_{\mathrm{tr}}$ & 3612,17 \\
\hline
\end{tabular}


10. ПРЕСМЕТКА НА КОЕФИЦИЕНТ СО СПЕЦИФИЧНИ ТОПЛИНСКИ ЗАГУБИ СО ТРАНСМИСИЈА Н'т - W/m²K

$\mathrm{Htr}=3$ 612,17 W/K ( вкупни трансмисиони топлотни загуби)

$\mathrm{A}=4645,92+80=4725,92 \mathrm{~m}^{2}$ (обвивка на зградата)

$\mathrm{H}^{\prime} \mathrm{T}=\mathrm{Htr}$, $\mathrm{A}=3$ 612,17 / 4 725,92 = 0,76 W/m² K

Од тука според формулата од Табела 2 од Правилникот следува

Н'т = 0,39+0,19 / fo ( за згради при поголема реконструкција )

$\mathrm{H}^{\prime} \mathrm{T}=0,39+0,19 / 0,30=0.39+0.63=1,02 \mathrm{~W} / \mathrm{m}^{2} \mathrm{~K}$

Вредноста $(0,76)$ е помала од вредностите во Табелата $(1,02)$.

11.ПРЕСМЕТКА НА ЕНЕРГЕТСКИТЕ ПОТРЕБИ (ЗА ГРЕЕЊЕ) НА ГОДИШНО НИВО Q СО ВКЛУЧЕНО ВЛИЈАНИЕ НА ТОПЛИНСКИТЕ МОСТОВИ

$\mathbf{Q}=\left(\mathrm{H}^{\prime} \mathbf{T} \times \Delta \mathrm{Utv} \times \mathbf{A} \times \mathbf{D D} \times \mathbf{h}\right) / \mathbf{A n}=$

$(0,76 \times 1.35 \times 4725,92 \times 2600 \times 10) / 3341,02=$

$126068641,92 / 3341,02=37733,578 \mathrm{Wh} / \mathrm{m} 2 \mathrm{a}=37,73 \mathbf{k W h} / \mathbf{~ m}^{2} \mathbf{a}$ каде:

H'т = $0.76 \mathrm{~W} / \mathrm{m}^{2} \mathrm{~K}$ - "коефициент на специфични топлински загуби со трансмисија" или топлински загуби причинети од минување на топлината низ обвивката на зградата.

$\Delta \mathrm{Utv}=1,35$

- корекционен фрактор на влијание на топлински мостови.

$A=4725,92 \mathrm{M} 2$

- обвивка на зграда.

$D D=2600$

- степен грејни денови од Правилникот.

$\mathrm{h}=10$

-- број на часови за греење во текот на еден ден.

An $=3341,02 \mathrm{~m} 2$

-- корисна грејна површина.

Со оваа пресметка од предлог Правилникот не се земени ВЕНТИЛАЦИОНИ топлотни загуби.

По извршените пресметки може да се заклучи дека кај постоечката состојба потрошувачката на топлинските трансмисиони загуби изнесува $130,76 \mathrm{kWh} / \mathrm{m}^{2} a$. Кај предвидената нова состојба потрошувачката е $37,73 \mathrm{kWh} / \mathbf{m}^{2} \mathbf{a}$.

Со тоа заштедата на топлинска енергија е приближно $71 \%$. 


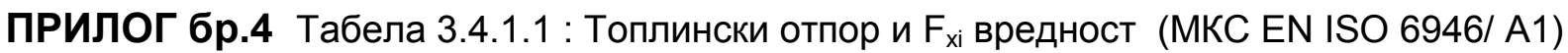

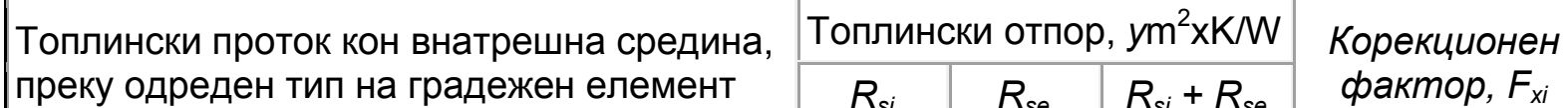

\begin{tabular}{|c|c|c|c|c|}
\hline \multicolumn{5}{|c|}{ Градежни елементи кој се граничат со надворешниот воздух } \\
\hline Надворешен зид & & & & \\
\hline невентилиран & 0,13 & 0,04 & 0,17 & 1,0 \\
\hline вентилиран & 0,13 & 0,13 & 0,26 & 1,0 \\
\hline Рамни кровови: & & & & \\
\hline невентилирани & 0,10 & 0,04 & 0,14 & 1,0 \\
\hline вентилирани & 0,10 & 0,10 & 0,20 & 1,0 \\
\hline Меѓукатна конструкција над пасаж: & & & & \\
\hline невентилирана & 0,17 & 0,04 & 0,21 & 1,0 \\
\hline вентилирана & 0,17 & 0,17 & 0,34 & 1,0 \\
\hline Коси кровови: & & & & \\
\hline невентилирани & 0,10 & 0,04 & 0,14 & 1,0 \\
\hline вентилирани & 0,10 & 0,10 & 0,20 & 1,0 \\
\hline
\end{tabular}

Градежни елементи кои се граничат со негреани простори

\begin{tabular}{|l|c|c|c|c|}
\hline Sид кон негреан простор & 0,13 & 0,13 & 0,26 & 0,5 \\
\hline $\begin{array}{l}\text { Меѓукатна конструкција кон негреан } \\
\text { кровен простор }\end{array}$ & 0,10 & 0,10 & 0,20 & 0,8 \\
\hline $\begin{array}{l}\text { Меѓукатна конструкција над негреан } \\
\text { простор }\end{array}$ & 0,17 & 0,17 & 0,34 & 0,5 \\
\hline $\begin{array}{l}\text { Sид кон негреана зимска градина } \\
\text { (стакленик), со надворешното } \\
\text { застаклување на зимската градина: }\end{array}$ & & & & \\
\hline Едноструко стакло, $\mathrm{U}>2,5 \mathrm{~W} /\left(\mathrm{m}^{2} \mathrm{xK}\right)$ & 0,13 & 0,13 & 0,26 & 0,7 \\
\hline Изолационо стакло, U $\leq 2,5 \mathrm{~W} /\left(\mathrm{m}^{2} \mathrm{xK}\right)$ & & & & 0,6 \\
\hline Подобрено стакло, $\mathrm{U} \geq 1,6 \mathrm{~W} /\left(\mathrm{m}^{2} \mathrm{xK}\right)$ & & & & 0,5 \\
\hline
\end{tabular}

Градежни елементи во контакт со тло

\begin{tabular}{|l|c|c|c|c|}
\hline Sид во тло, или делумно вкопан & 0,13 & 0,0 & 0,13 & 0,6 \\
\hline Под на тло & 0,17 & 0,0 & 0,17 & 0,5 \\
\hline Меѓукатна конструкција на тло & 0,10 & 0,0 & 0,10 & 0,6 \\
\hline
\end{tabular}

Градежни елементи меѓу два греани простори со различна температура

Кид помеѓу згради, зид кој раздвојува простории на различни корисници, или зид кон греано скалиште

Меѓукатна конструкција која го дели просторот меѓу различни кориснициrazdvaja

\begin{tabular}{c|c|c|c}
0,13 & 0,08 & 0,21 & 0,8 \\
\hline 0,10 & 0,08 & 0,18 & 0,8
\end{tabular}


Табела 1: Максимално дозволени коефициенти на пренесување на топлината Umax - според Правилникот на Општина Карпош (2012:15)

\begin{tabular}{|c|c|c|c|}
\hline \multirow[b]{2}{*}{$\begin{array}{l}\text { Ред. } \\
\text { број }\end{array}$} & \multirow[b]{2}{*}{ Градежна конструкција } & \multicolumn{2}{|l|}{$U \max -\mathrm{W} / \mathrm{M}^{2} \cdot \mathrm{K}$} \\
\hline & & $\begin{array}{l}\text { Згради со } \\
\text { внатрешна } \\
\text { температура } \geq 18^{\circ} \mathrm{C}\end{array}$ & $\begin{array}{l}\text { Нискотемпературни } \\
\text { згради или зони со } \\
\text { внатрешна } \\
\text { температура од } 12- \\
18^{\circ} \mathrm{C}\end{array}$ \\
\hline 1 & $\begin{array}{l}\text { Надворешни зидови и зидови } \\
\text { кон негреани простори }\end{array}$ & 0,35 & 0,60 \\
\hline 2 & $\begin{array}{l}\text { Sидови меѓу греани простори } \\
\text { со различни грејни системи, } \\
\text { различни сопственици или } \\
\text { корисници }\end{array}$ & 0,60 & Нема услов \\
\hline 3 & $\begin{array}{l}\text { Надворешни зидови вкопани во } \\
\text { терен }\end{array}$ & 0,60 & 0,80 \\
\hline 4 & $\begin{array}{l}\text { Меѓукатна конструкција меѓу } \\
\text { греани простори }\end{array}$ & 1,35 & 1,35 \\
\hline 5 & $\begin{array}{l}\text { Меѓукатна конструкција над } \\
\text { негреан простор }\end{array}$ & 0,35 & 0,45 \\
\hline 6 & Подна конструкција на терен & 0,40 & 0,70 \\
\hline 7 & $\begin{array}{l}\text { Меѓукатна конструкција на д } \\
\text { отворен простор еркер }\end{array}$ & 0,30 & 0,45 \\
\hline 8 & $\begin{array}{l}\text { Рамни или коси покриви над } \\
\text { греан простор }\end{array}$ & 0,20 & 0,60 \\
\hline 9 & 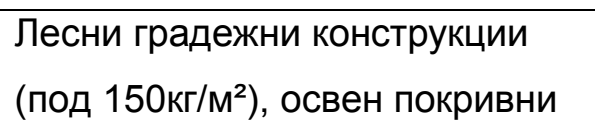 & 0,30 & 0,40 \\
\hline 10 & $\begin{array}{l}\text { Прозорци и балконски врати со } \\
\text { рамки од ПВЦ и двослојно или } \\
\text { трослојно застаклување }\end{array}$ & 1,70 & 2,00 \\
\hline
\end{tabular}




\begin{tabular}{|l|l|c|c|}
\hline 11 & $\begin{array}{l}\text { Прозорци и балконски врати со } \\
\text { рамки од дрво и прозорци во } \\
\text { потпокрив, со двослојно или } \\
\text { трослојно застаклување }\end{array}$ & 2,00 \\
\hline 12 & $\begin{array}{l}\text { Прозорци и балконски врати со } \\
\text { рамки од метал со топлински } \\
\text { прекини на топлинските } \\
\text { мостови }\end{array}$ & 2,00 & 2,00 \\
\hline 13 & Висечки фасади & 1,9 & \\
\hline
\end{tabular}

